\title{
Reconnaissance of Ground-Water Quality in the North Platte Natural Resources District, Western Nebraska, June-July 1991
}

\author{
By I.M. VERSTRAETEN, U.S. Geological Survey, \\ S.S. SIBRAY, University of Nebraska-Lincoln Conservation \\ and Survey, J.C. CANNIA, North Platte Natural Resources \\ District, and D.Q. TANNER, U.S. Geological Survey
}

U.S. GEOLOGICAL SURVEY

Water-Resources Investigations Report 94-4057

Prepared in cooperation with the

North Platte Natural Resources District,

Nebraska Natural Resources Commission, and

University of Nebraska-Lincoln, Institute of Agriculture and

Natural Resources, Conservation and Survey Division

Lincoln, Nebraska

1995 


\section{U.S. DEPARTMENT OF THE INTERIOR \\ BRUCE BABBITT, Secretary}

U.S. GEOLOGICAL SURVEY

GORDON P. EATON, Director

For additional information write to:

District Chief

U.S. Geological Survey

406 Federal Building

100 Centennial Mall, North

Lincoln, NE 68508
Copies of this report can be purchased from:

U.S. Geological Survey

Earth Science Information Center Open-File Reports Section

Box 25286, MS 517

Denver Federal Center

Denver, Colorado 80225 


\section{CONTENTS}

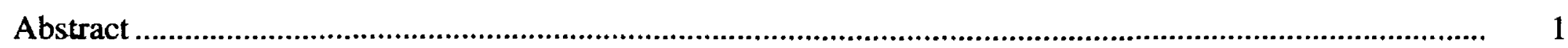

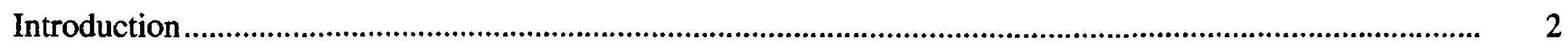

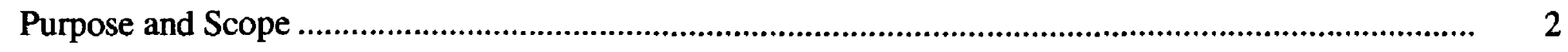

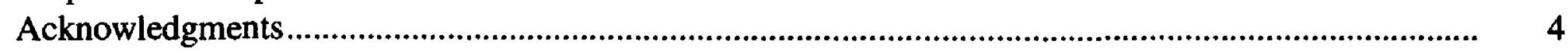

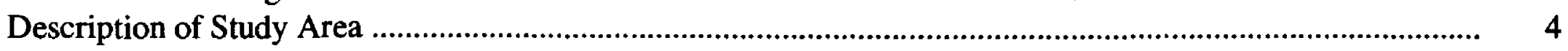

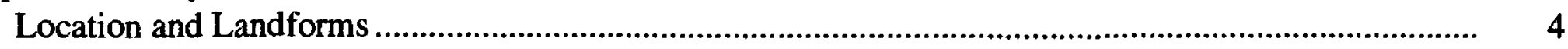

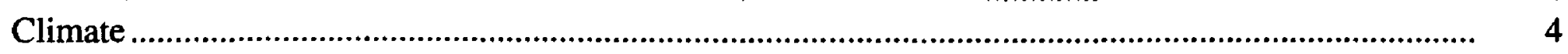

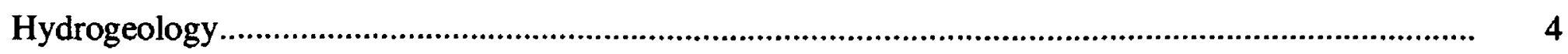

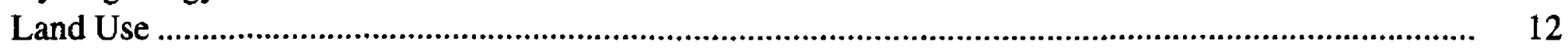

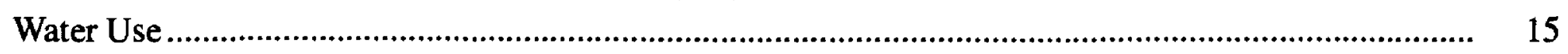

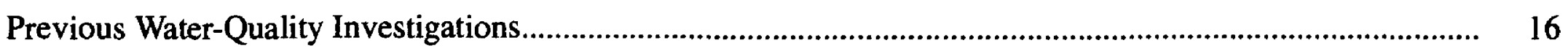

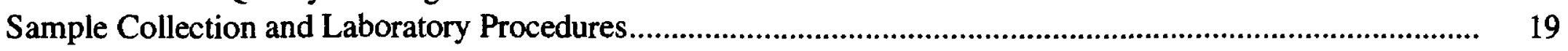

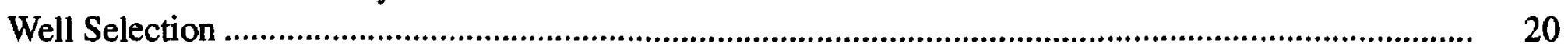

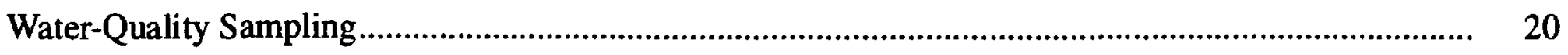

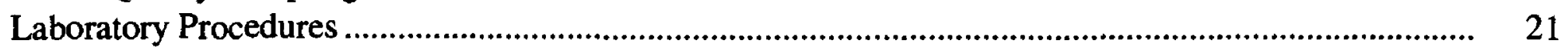

Quality Control and Quality Assurance ............................................................................................ 23

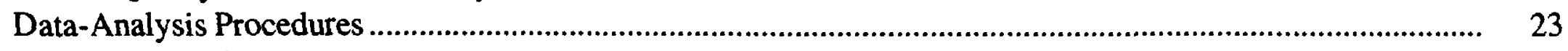

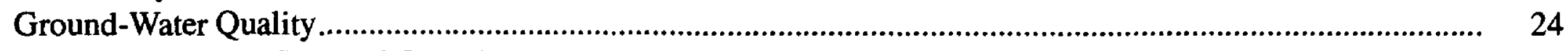

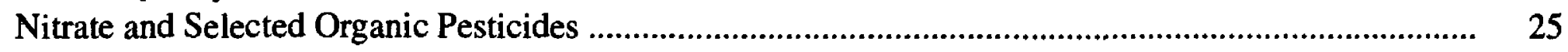

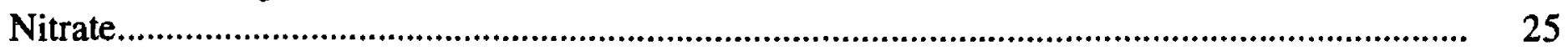

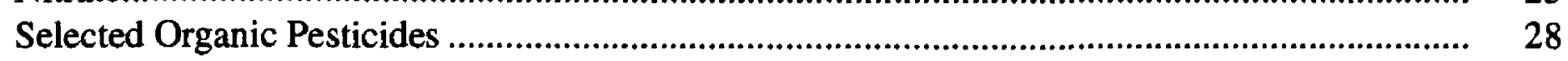

Major Cations and Anions, pH, Dissolved Oxygen, Specific Conductance, and Calculated Dissolved

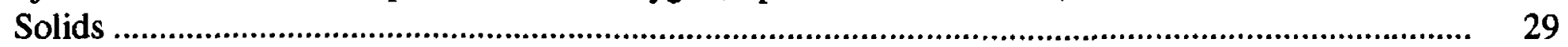

Major Cations and Anions and Water Types....................................................................... 29

General Statistical Analytical Results....................................................................... 29

Summary of Water Chemistry and Water Types by Water-Bearing Units ...................... 36

Quaternary-Age Water-Bearing Units............................................................. 36

Ogallala Group and Arikaree Group Water-Bearing Units and Fractured-Bedrock and Sand Water-Bearing Units in the Brule Formation ................................ 37

Chadron Formation Water-Bearing Units and Undifferentiated Water-Bearing Units of Cretaceous Age ........................................................................... 37

$\mathrm{pH}$ and Dissolved Oxygen .................................................................................................... 38

Specific Conductance and Calculated Dissolved Solids ..................................................... 39

Major Metals and Selected Trace Elements ............................................................................................ 39

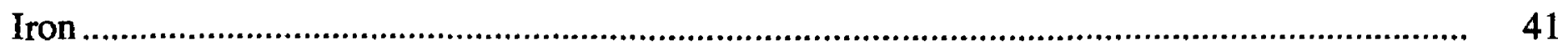

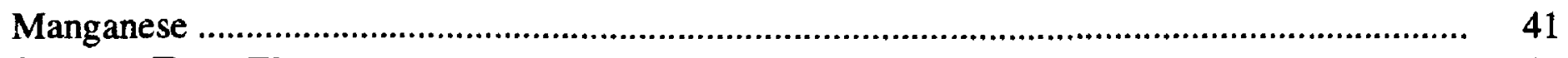

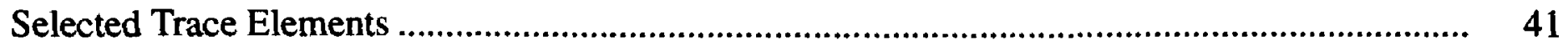

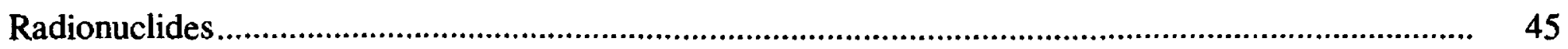

Gross Alpha and Beta Activities ...................................................................................... 45

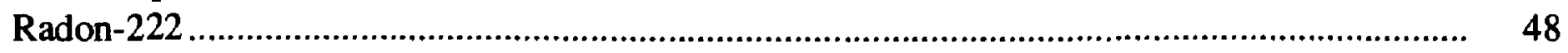

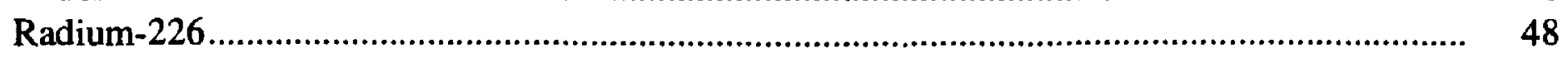

Total Uranium and Uranium Activity Ratio 234/238 .......................................................... 48

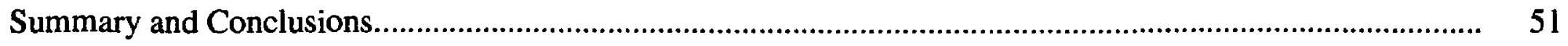

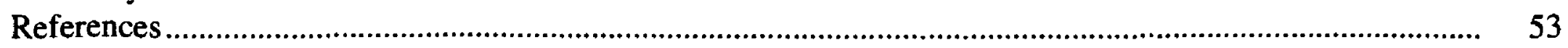




\section{FIGURES}

1.-9. Maps showing:

1. Location of North Platte Natural Resources District, western Nebraska

2. Landforms and geographic areas in the North Platte Natural Resources District, western Nebraska

3. Traces of generalized geologic sections and generalized geologic sections A-A' and B-B' in the North Platte Natural Resources District, western Nebraska

4. Areal distribution of sediments of Pliocene and Quaternary age in the North Platte Natural Resources District, western Nebraska

Bedrock of the Brule Formation, Arikaree Group, and Ogallala Group in the North Platte Natural Resources District, western Nebraska

6. Areal distribution of sandstone and conglomerate in the lower part of the Chadron Formation in the North Platte Natural Resources District, western Nebraska.

7. Surface-water use districts in the North Platte Natural Resources District, western Nebraska......

8. Location of sampled wells, North Platte Natural Resources District, western Nebraska.

9. Dissolved-nitrate concentrations in ground water, June and July 1991, North Platte Natural Resources District, western Nebraska.

10.-11. Graphs showing:

10. Distribution of dissolved-nitrate concentrations by water-bearing unit, well depth by waterbearing unit, and dissolved-nitrate concentrations by county in ground water, June and July 1991, North Platte Natural Resources District, western Nebraska.

11. Relation between dissolved-nitrate concentration in ground-water samples and well depth, North Platte Natural Resources District, western Nebraska

12. Map showing locations of sampled wells and wells with ground water containing detectable concentrations of the herbicides alachlor, atrazine, deethylatrazine, or prometon, June and July 1991, North Platte Natural Resources District, western Nebraska.....

13. Diagrams showing ionic composition of ground water by water-bearing unit, North Platte Natural Resources District, western Nebraska.

14.-18. Graphs showing:

14. Distributions of field $\mathrm{pH}$, water temperature, dissolved oxygen, hardness, alkalinity, calcium, magnesium, sodium, sodium-adsorption ratio, potassium, sulfate, chloride, fluoride, and silica by water-bearing unit, June and July 1991, North Platte Natural Resources District, western Nebraska

15. Distribution of specific conductance and calculated dissolved solids in ground-water samples by water-bearing unit, June and July 1991, North Platte Natural Resources District, western Nebraska, and the relation between specific conductance and calculated dissolvedsolids concentration

16. Distribution of selected trace elements by water-bearing unit, June and July 1991, North Platte Natural Resources District, western Nebraska

17. Distribution of radionuclides by water-bearing unit and distribution of uranium by county, June and July 1991, North Platte Natural Resources District, western Nebraska...................................

18. Uranium-238 radioactive decay series

19. Map showing radon-222 activities in water from sampled wells, June and July 1991, North Platte Natural Resources District, western Nebraska

\section{TABLES}

1. Hydrogeologic units, North Platte Natural Resources District, western Nebraska ................................. 6

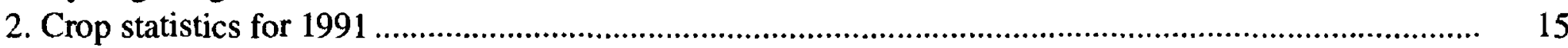

3. Most frequently applied herbicides, insecticides, and nematocides on cropland in the Nebraska Panhandle

4. Estimated water use for public supply and self supply in the North Platte Natural Resources District, western Nebraska, 1990. 


\section{TABLES-Continued}

5. Number of wells selected for constituent analysis by water-bearing unit

6. Summary of water-quality analyses of selected properties of ground water and concentrations of nitrate plus nitrite as nitrogen, herbicides, and insecticides, North Platte Natural Resources District, western Nebraska, June and July 1991

7. Summary of results of analyses of ground water, North Platte Natural Resources District, western Nebraska, June and July 1991

8. Statistical summary of all water-quality analyses, except pesticides, North Platte Natural Resources District, western Nebraska, June and July 1991, and U.S. Environmental Protection Agency (USEPA) drinking-water regulations

9. Statistical summary of water-quality analyses, except pesticides, for samples from water-bearing units of Quaternary age, North Platte Natural Resources District, western Nebraska, June and July 1991, and U.S. Environmental Protection Agency (USEPA) drinking-water regulations.

10. Statistical summary of water-quality analyses, except pesticides, for samples from Ogallala Group water-bearing units, North Platte Natural Resources District, western Nebraska, June and July 1991, and U.S. Environmental Protection Agency (USEPA) drinking-water regulations.

11. Statistical summary of water-quality analyses, except pesticides, for samples from Arikaree Group water-bearing units, North Platte Natural Resources District, western Nebraska, June and July 1991, and U.S. Environmental Protection Agency (USEPA) drinking-water regulations.

12. Statistical summary of water-quality analyses, except pesticides, for samples from fractured-bedrock water-bearing units in the Brule Formation, North Platte Natural Resources District, western Nebraska, June and July 1991, and U.S. Environmental Protection Agency (USEPA) drinking-water regulations

13. Statistical summary of water-quality analyses, except pesticides, for samples from sand waterbearing units in the Brule Formation, North Platte Natural Resources District, western Nebraska, June and July 1991, and U.S. Environmental Protection Agency (USEPA) drinking-water regulations.

14. Statistical summary of water-quality analyses, except pesticides, for samples from Chadron Formation water-bearing units, North Platte Natural Resources District, western Nebraska, June and July 1991, and U.S. Environmental Protection Agency (USEPA) drinking-water regulations

15. Statistical summary of water-quality analyses, except pesticides, for samples from undifferentiated water-bearing units of Cretaceous age, North Platte Natural Resources District, western Nebraska, June and July 1991, and U.S. Environmental Protection Agency (USEPA) drinkingwater regulations

16. Results of Kruskal-Wallis and Wilcoxon Rank Sum tests on differences in water chemistry among water-bearing units and two groups of water-bearing units, respectively.....

17. Statistically significant results (alpha $=0.05$ ) of the Tukey's test to test for differences in median concentrations of water-quality variables among water-bearing units, North Platte Natural Resources District, western Nebraska. 


\section{CONVERSION FACTORS AND VERTICAL DATUM}

\begin{tabular}{rcl}
\hline Multiply & By & To obtain \\
\hline acre & 4,047 & square meter \\
foot & 0.3048 & meter \\
gallon per minute & 0.06309 & liter per second \\
inch & 25.4 & millimeter \\
inch per hour & 25.4 & millimeter per hour \\
mile & 1.609 & kilometer \\
million gallons per day & 0.04381 & cubic meter per second \\
pound & 453.6 & gram \\
square mile & 2.590 & square kilometer \\
ton & 0.9072 & megagram \\
\hline
\end{tabular}

To convert degree Fahrenheit $\left({ }^{\circ} \mathrm{F}\right)$ to degree Celsius $\left({ }^{\circ} \mathrm{C}\right)$ use the following formula:

$$
{ }^{\circ} \mathrm{C}=5 / 9\left({ }^{\circ} \mathrm{F}-32\right)
$$

Sea level: In this report, "sea level" refers to the National Geodetic Vertical Datum of 1929-a geodetic datum derived from a general adjustment of the first-order level nets of the United States and Canada, formerly called Sea Level Datum of 1929.

The use of brand or trade names in this report is for identification purposes only and does not constitute endorsement by the U.S. Geological Survey. 


\title{
Reconnaissance of Ground-Water Quality in the North Platte Natural Resources District, Western Nebraska, June-July 1991
}

\author{
By I.M. Verstraeten, S.S. Sibray, J.C. Cannia, and D.Q. Tanner
}

\begin{abstract}
This report presents a reconnaissance of the ground-water quality in the North Platte Natural Resources District of western Nebraska. One hundred twenty wells completed in unconfined Quaternary age, Ogallala Group, and Arikaree Group water-bearing units, fractured-bedrock and sand waterbearing units in the Brule Formation, confined Chadron Formation water-bearing units, and undifferentiated water-bearing units of Cretaceous age were sampled during June and July 1991 .
\end{abstract}

Overall, more than 75 percent of the water samples had dissolved nitrate plus nitrite as nitrogen concentrations equal to or less than 6 milligrams per liter. Water samples from six wells completed in Quaternary-age waterbearing units and fractured-bedrock waterbearing units in the Brule Formation exceeded the U.S. Environmental Protection Agency Primary Maximum Contaminant Level of 10 milligrams per liter for dissolved nitrate plus nitrite as nitrogen. Conversely, water samples collected from sandstone and conglomerate of the confined Chadron Formation water-bearing units and undifferentiated water-bearing units of Cretaceous age had concentrations of dissolved nitrate plus nitrite as nitrogen generally less than the detection level, which may indicate the presence of a reducing environment disassociating the dissolved-nitrate ion as supported by the low dissolved-oxygen concentrations detected in the water from these units or reduced leaching at depth due to the presence of confining layers. Water from several wells completed in Quaternary-age water-bearing units and fractured-bedrock and sand water-bearing units in the Brule Formation had detectable concentrations of alachlor, atrazine, deethylatrazine, or prometon.

Insecticides were not detected in ground water in the study area.

Major element concentrations in the water from 44 wells indicated that the water-bearing units had distinct chemistry. Water from the Quaternary-age, Ogallala Group, and Arikaree Group water-bearing units, and fracturedbedrock and sand water-bearing units in the Brule Formation generally was a calcium bicarbonate type with moderate hardness, and water from the Chadron Formation waterbearing units and undifferentiated waterbearing units of Cretaceous age generally was a sodium bicarbonate type with soft, mineralized water reflecting the older age of the water. Water samples from Quaternary-age waterbearing units had significantly different distributions of concentrations of calcium, magnesium, potassium, and sulfate than water samples from the other water-bearing units.

Overall, the quality of water from Chadron Formation and undifferentiated water-bearing units of Cretaceous age is not suitable for domestic and irrigation use. High $\mathrm{pH}$ and concentrations of calculated dissolved solids, sodium, chloride, fluoride, arsenic, and beryllium that exceeded U.S. Environmental Protection Agency Primary or Secondary Maximum Contaminant Levels characterized the water in these units. Water in the Chadron Formation water-bearing units and undifferen- 
tiated water-bearing units of Cretaceous age, characterized by a relatively large degree of mineralization and softer water, had significantly different distributions of concentrations of all major ions except potassium, sulfate, and chloride than water from the other units.

Water-quality data from the Quatemaryage water-bearing units indicated that adjusted gross-alpha activities in the units also exceeded U.S. Environmental Protection Agency Maximum Contaminant Levels. In addition, samples from 39 of the 44 wells completed in all water-bearing units, except for the Arikaree Group water-bearing units, had radon activities that exceeded the proposed Primary Maximum Contaminant Level of 300 picocuries per liter. The radon activities were different in water samples from the fractured-bedrock and sand water-bearing units in the Brule Formation than in those from the other water-bearing units. Nine of the 44 water samples from wells completed in Quaternary-age and Ogallala Group waterbearing units had uranium concentrations that exceeded the U.S. Environmental Protection Agency Primary Maximum Contaminant Level of 20 micrograms per liter.

\section{INTRODUCTION}

Ground water is the primary source of drinking water in Nebraska, but a common problem is the presence of dissolved-nitrate concentrations in ground water (Conservation and Survey Division, $1980 \mathrm{a} ; 1980 \mathrm{~b}$ ) that exceed the $10 \mathrm{mg} / \mathrm{L}$ (milligram per liter) primary Maximum Contaminant Level (MCL) for dissolved nitrate plus nitrite as nitrogen established by the U.S. Environmental Protection Agency (USEPA) (1988a). The use of herbicides, insecticides, and fungicides, as well as the addition of fertilizer to soil and irrigation water, has affected the ground-water quality in Nebraska (Spalding and others, 1978; Gormly and Spalding, 1979; Exner, 1990; Spalding, 1991). Radionuclides, such as gross-alpha, gross-beta, and radon activities, in ground water have received more recent attention from the Nebraska Department of Health
(A.M. Pour, Nebraska Department of Health, oral commun., 1992).

The State of Nebraska has been divided into 23 Natural Resources Districts (NRDs) to address natural-resource issues of soil and water management. Originally, each NRD was required to submit a ground-water management plan to the Nebraska Department of Water Resources by January 1986. Under Nebraska Law LB 51 (1991), each NRD is required to amend the water-quality section of its ground-water management plan by July 1, 1993. LB 51 (1991) states the amended plans are to "... identify levels and sources of ground-water contamination and to recommend practices that would stabilize, reduce, and prevent to the extent possible additional spread, occurrences, and increases of ground-water contamination." The U.S. Geological Survey entered into a cooperative agreement with the North Platte Natural Resources District (NRD) in 1990 to conduct a water-quality study to determine the chemical character of water in the primary waterbearing units. The study focused on dissolved nitrate plus nitrite as nitrogen, agricultural organic pesticides, and radionuclide concentrations.

\section{Purpose and Scope}

This report provides a general description of the water quality of the principal water-bearing units in the North Platte NRD (fig. 1). Constituent concentrations are compared with USEPA Drinking-Water Regulations. Variations in concentration are discussed in relation to water-bearing units. The report emphasizes the spatial distribution of dissolved nitrate plus nitrite as nitrogen and selected pesticides, including carbamate insecticides and triazine and acetanilide herbicides. The report also describes the concentrations of major and trace-element constituents, including radionuclides in ground water. Whereas organic industrial compounds associated with landfills, spills, and underground storage tanks were not addressed in this study, the effects of agricultural practices on ground-water quality were evaluated on the basis of the concentrations of organic and inorganic constituents. 


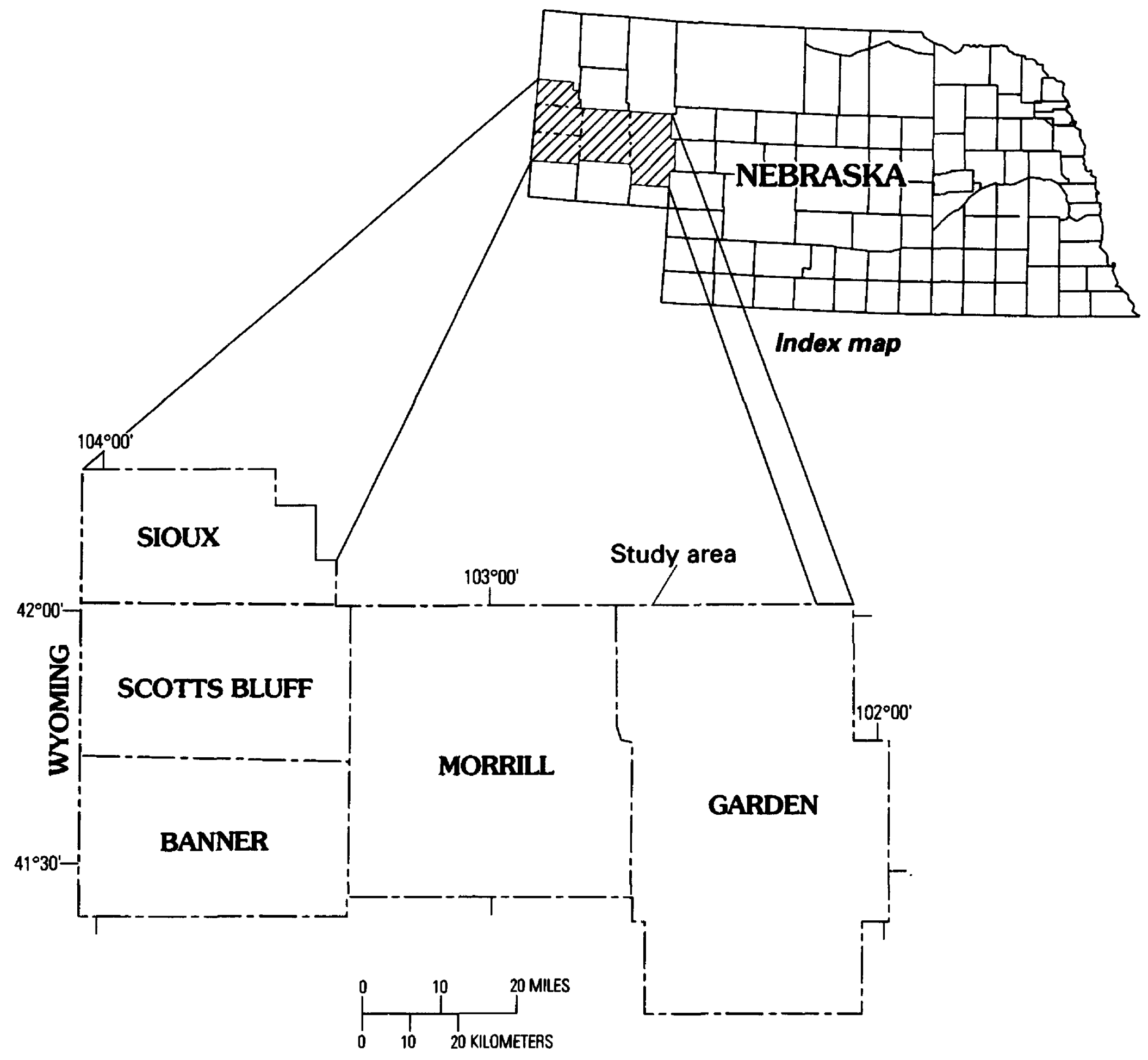

Figure 1. Location of North Platte Natural Resources District, western Nebraska. 


\section{Acknowledgments}

The authors thank well owners in the study area for granting permission to sample their wells and for their assistance in the field.

\section{DESCRIPTION OF STUDY AREA}

\section{Location and Landforms}

The North Platte NRD covers approximately 5,124 square miles in the central part of the Nebraska Panhandle and includes Banner, Garden, Morrill, and Scotts Bluff Counties and the southern part of Sioux County (fig. 1). Most of the study area lies in the North Platte River Basin. The population of approximately 45,000 in 1990-91 (Clerk of the Legislature, 1991) is concentrated in small towns located along the North Platte River. The largest town is Scottsbluff with a population of approximately 13,700 .

The North Platte NRD is located in the High Plains section of the Great Plains physiographic province, as defined by Fenneman (1931). The study area can be divided further by landforms and geographic areas (fig. 2).

The Cheyenne Tablelands, Northern Tablelands, and Wildcat Ridge are erosional remnants of the High Plains, which slope eastward from the Front Range of the Rocky Mountains. Erosion of the Pumpkin Creek and North Platte Valleys has left steep escarpments and ridges adjacent to the valleys. The Sandhills Region, located in northeastern Morrill County and northern Garden County, consists of sand dunes that were deposited within the last 8,000 years (Ahlbrandt and others, 1983) and now generally are covered with grass.

\section{Climate}

The climate of the study area is characterized by extreme temperature ranges and relatively low average annual precipitation, typical of a midlatitude, continental setting. On the basis of records from 1951 to 1980 at the Scottsbluff weather station, the mean annual temperature is $48.5^{\circ} \mathrm{F}$, the mean maximum temperature in July is $89.2^{\circ} \mathrm{F}$, and the mean minimum temperature in
January is $11.2{ }^{\circ} \mathrm{F}$ (National Oceanic and Atmospheric Administration, 1982). Mean annual precipitation is 15 to 18 inches on the basis of records from 1951 to 1980 (Lawson and others, 1977). Most of the precipitation is produced by thunderstorms during late spring and early summer. May and June are the two wettest months of the year. Potential evapotranspiration in the area usually is greater than precipitation (I awson and others, 1977).

\section{Hydrogeology}

Many earlier investigations describe the geology and occurrence of ground water in the study area (Darton, 1903a, 1903b; Wenzel and others, 1946; Smith and Souders, 1975; Souders, 1986). A summary of the hydrogeologic units of the study area is given in table 1 . Generalized geologic sections are presented in figure 3 . The stratigraphic nomenclature used in this report conforms with the usage as described by Swinehart and others (1985).

In general, sufficient differences in the hydrologic and geochemical characteristics among the water-bearing units in the study area exist to warrant discussion of the water-bearing units separately. However, the sediments of the Ogallala and Arikaree Groups are not sufficiently different within each group from a hydrogeologic perspective to justify further subdivision of the Ogallala or Arikaree Groups in this report. Because of differences in the hydrogeologic characteristics between the fractured bedrock (secondary permeability) and the sand deposits (primary permeability) in the Brule Formation, the Brule Formation was divided into the fractured-bedrock and sand or channel water-bearing units of the Brule Formation, referred to as fractured-bedrock and sand water-bearing units of the Brule Formation in the remainder of the text.

The areal distribution of sediments of Pliocene and Quaternary age is shown in figure 4. The most intensively developed water-bearing units in the study area are the Quaternary-age water-bearing units located in the Pumpkin Creek and North Platte Valleys. The Pleistocene sand and gravel water-bearing units consist largely of granitic and metamorphic material. Depth to the water table is generally less than 50 feet. 


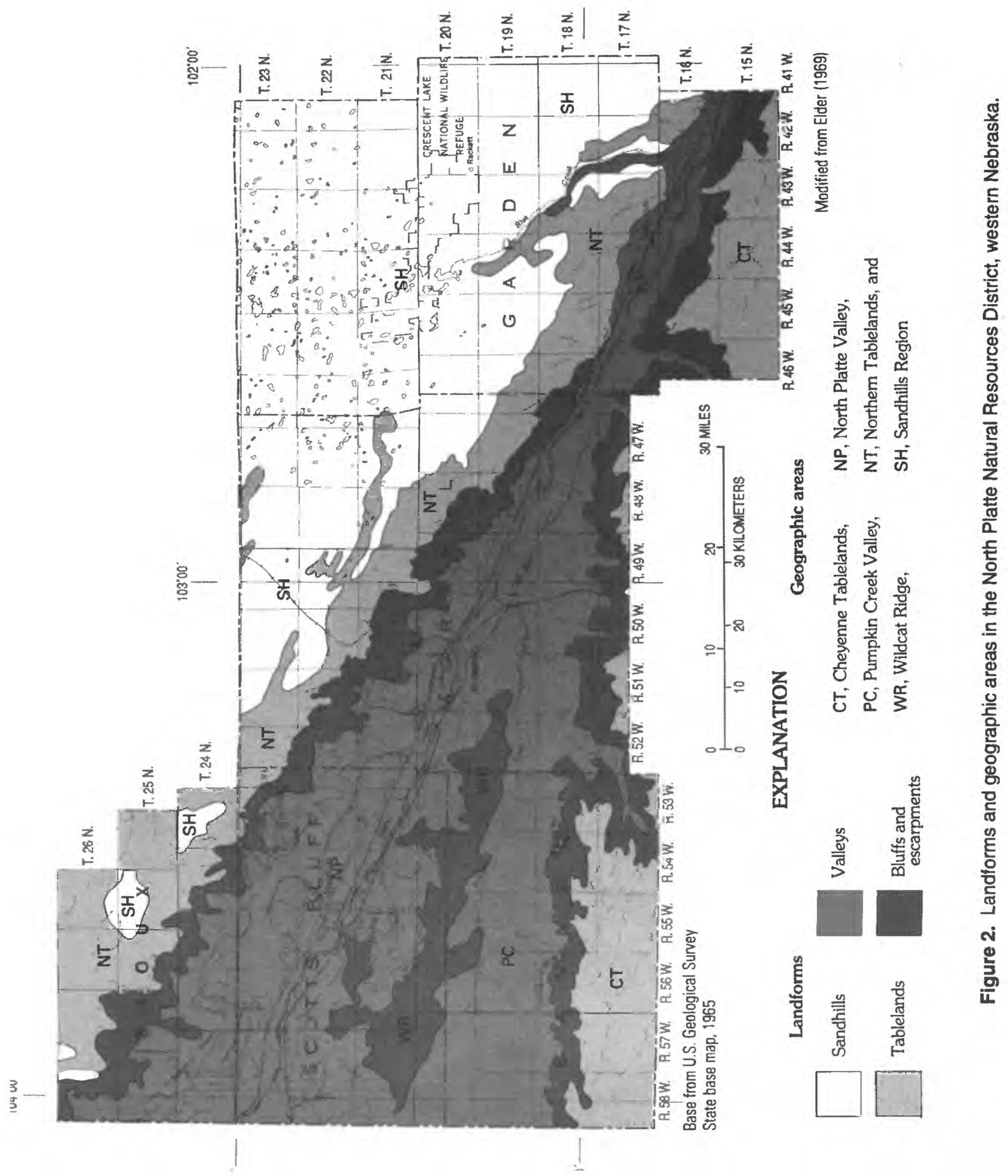




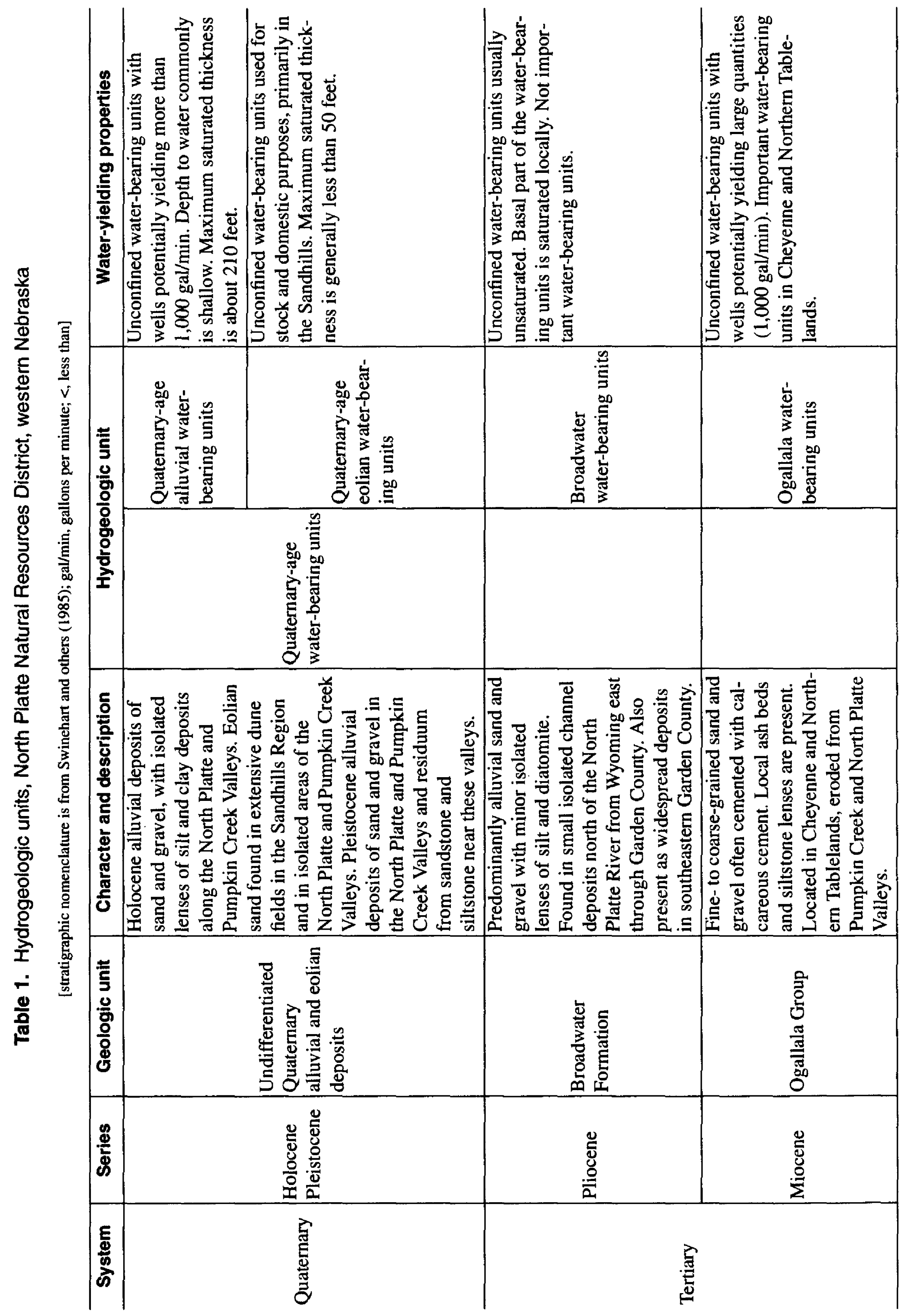




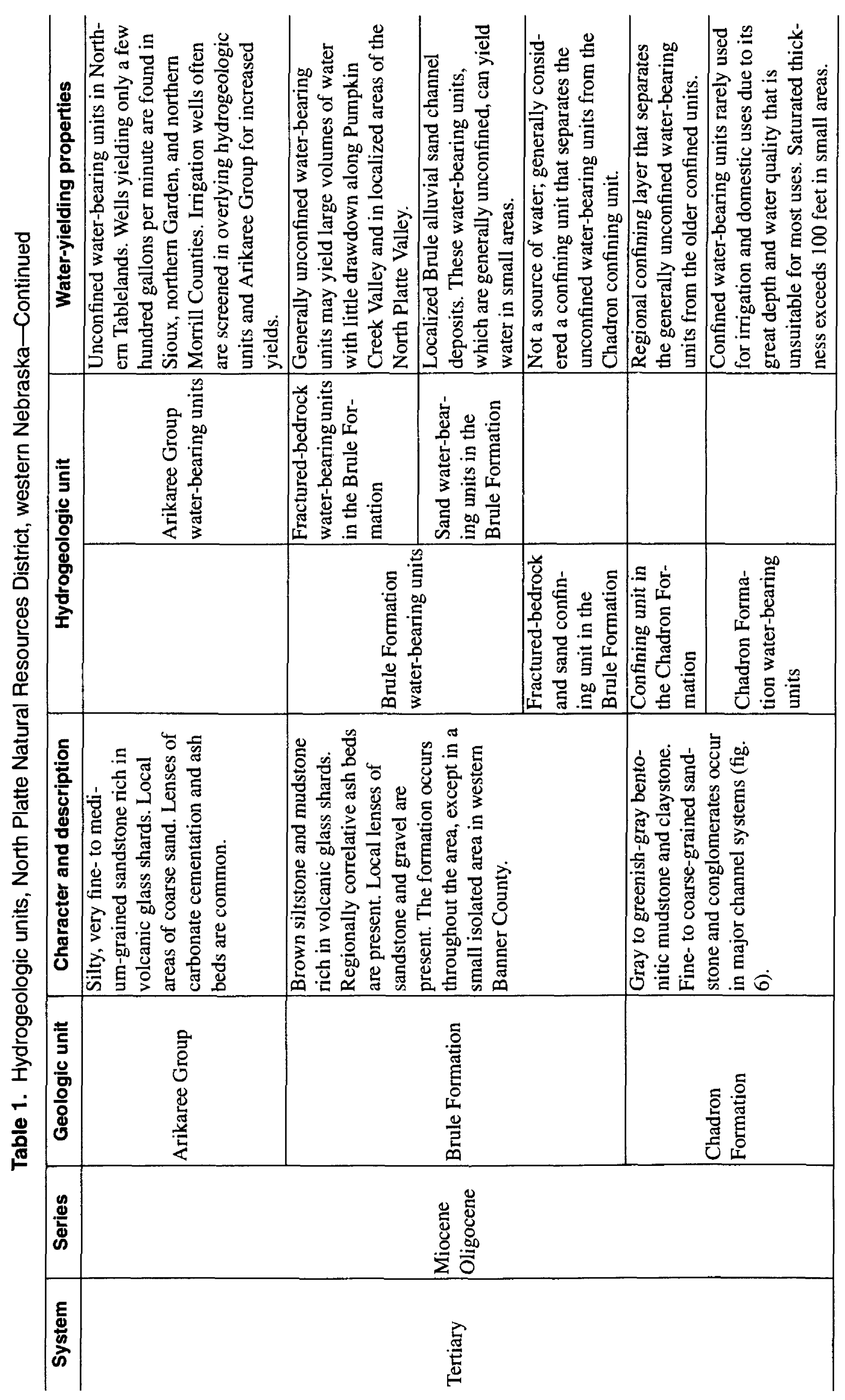




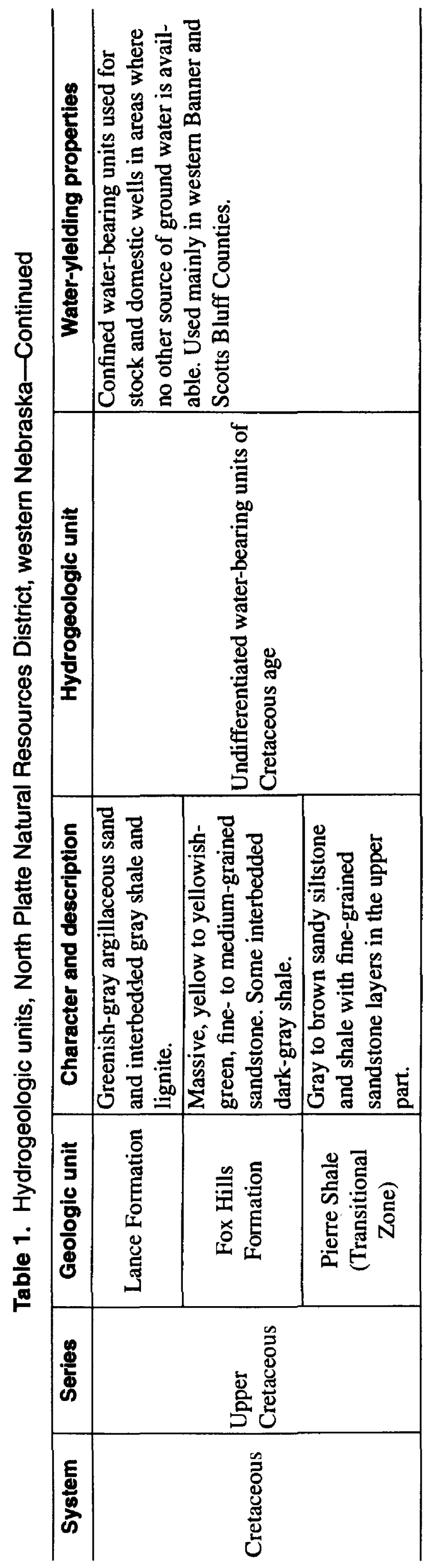




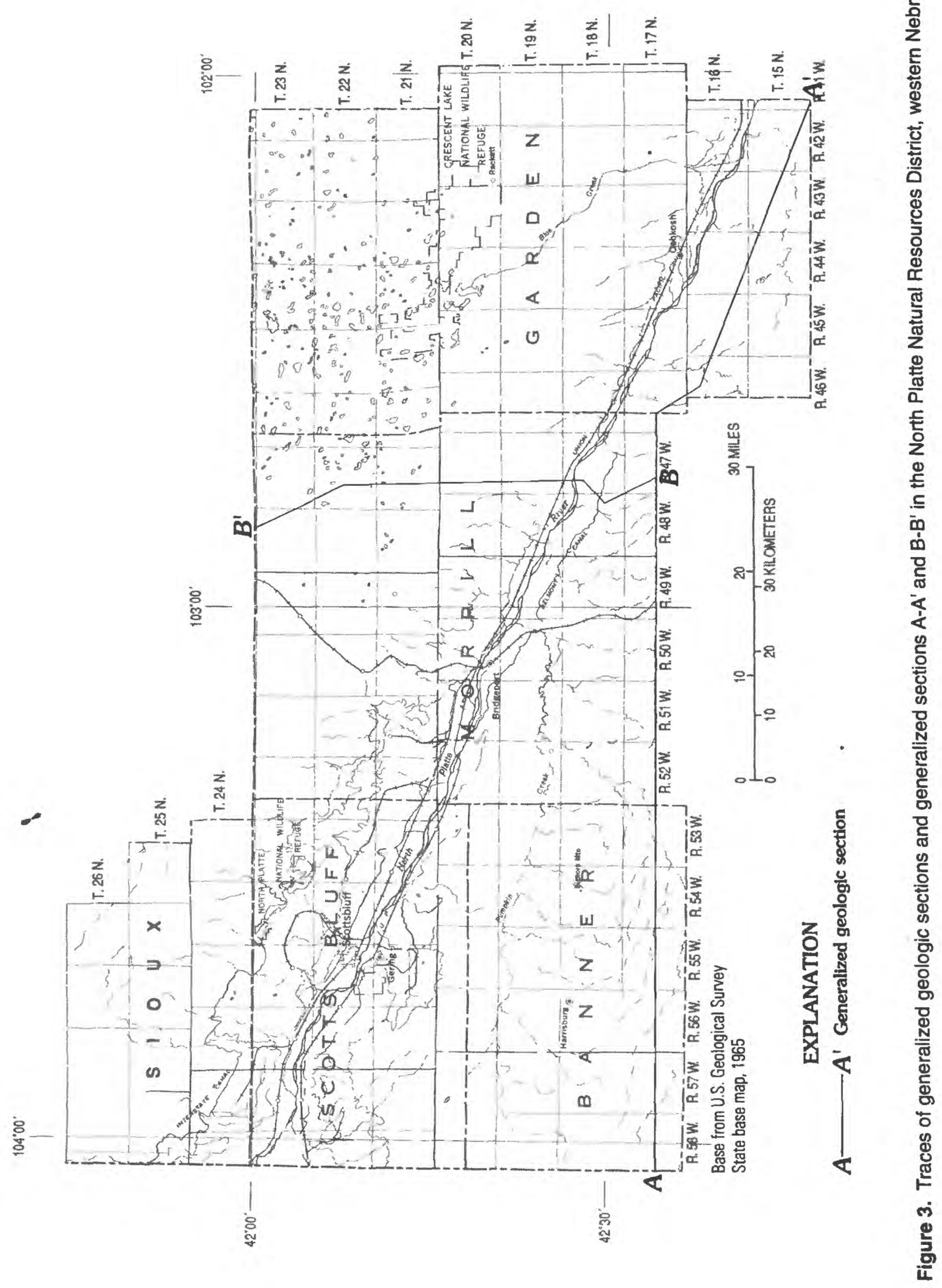



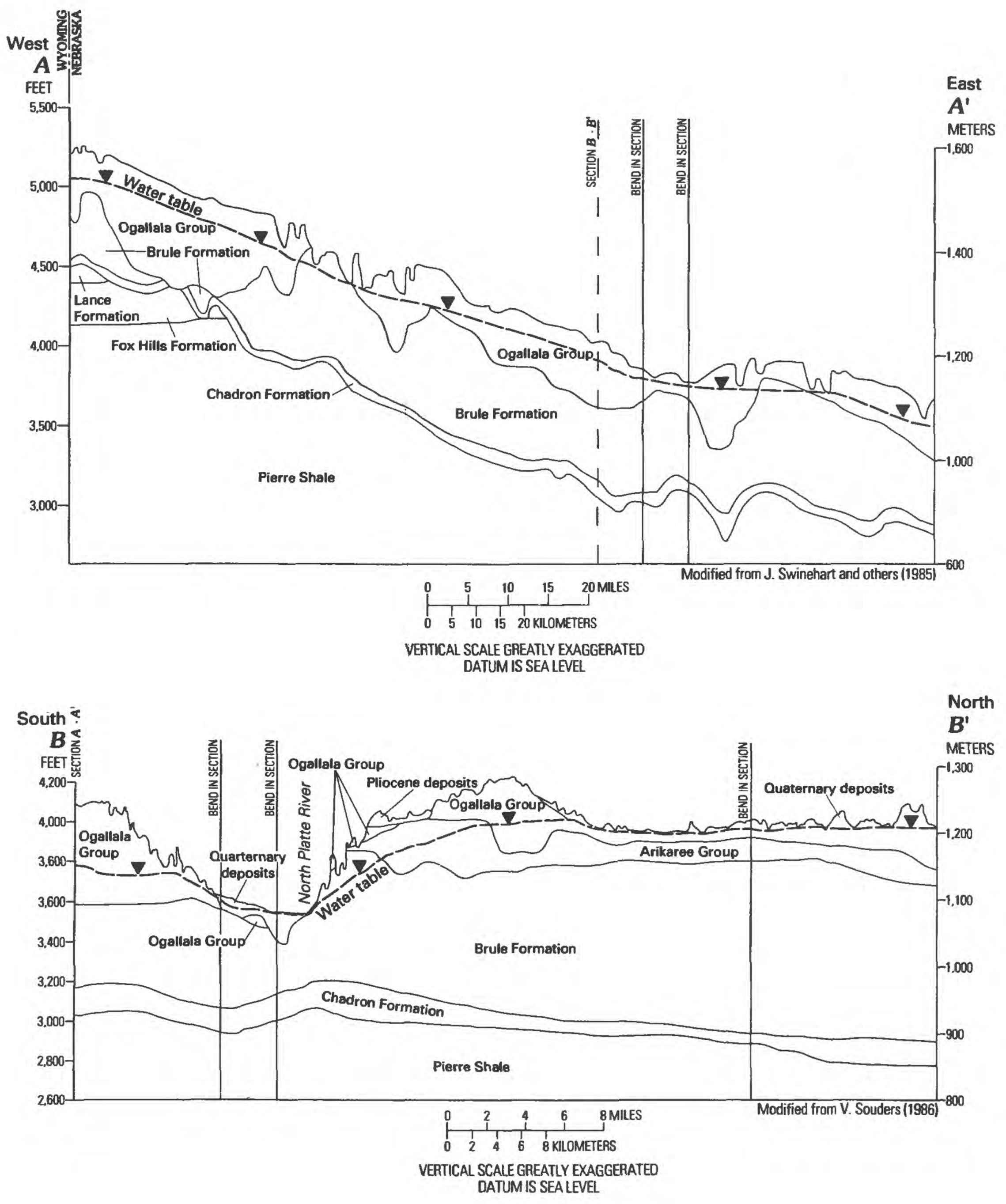

Figure 3. Traces of generalized geologic sections and generalized sections $A-A^{\prime}$ and $B-B^{\prime}$ in the North Platte Natural Resources District, western Nebraska-Continued. 


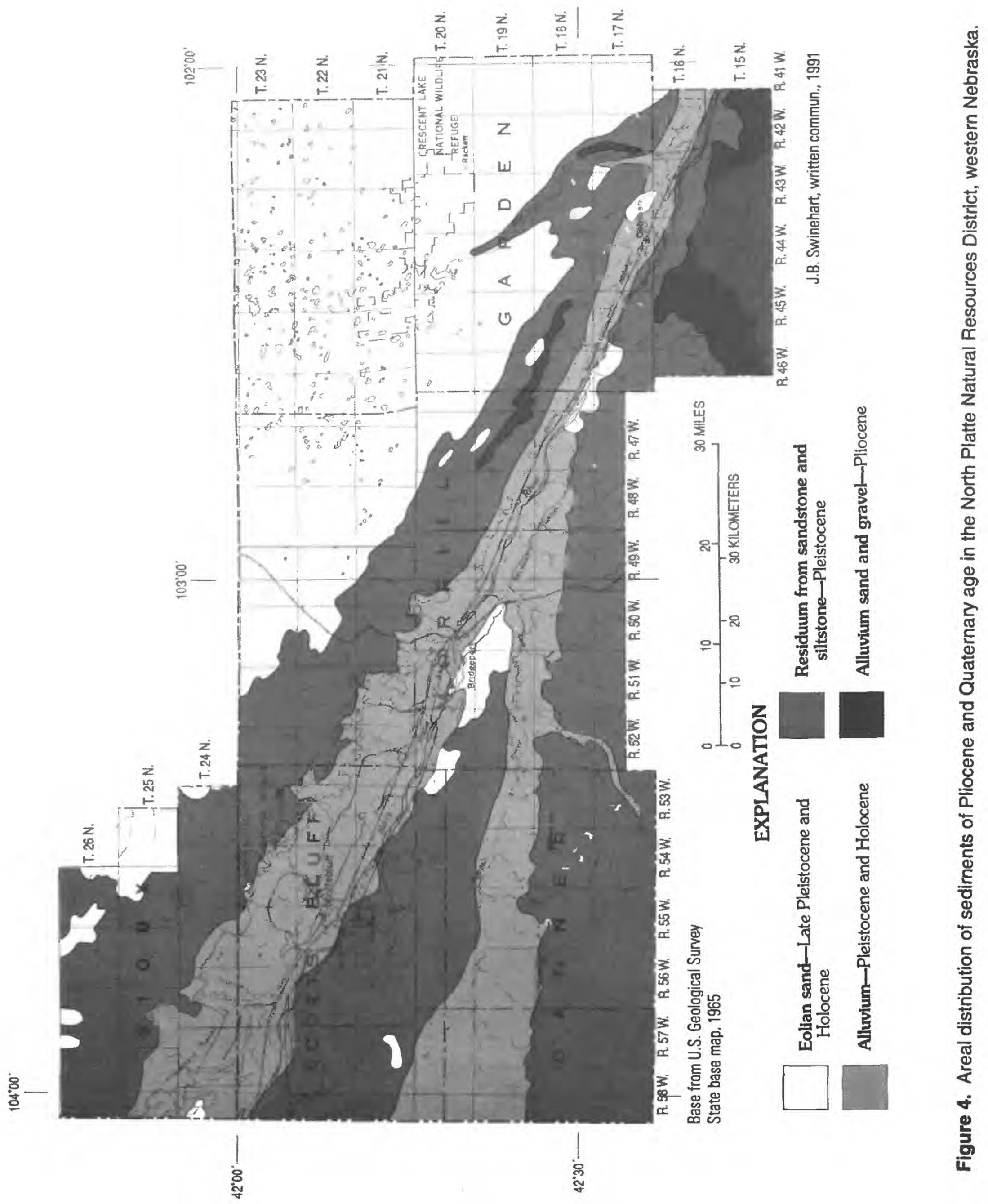


The Tertiary-Pliocene Broadwater Formation consists of unconsolidated alluvial sand and gravel and is mostly unsaturated. The areal distribution of the Tertiary Ogallala and Arikaree Group water-bearing units and fractured-bedrock and sand water-bearing units of the Brule Formation in the study area is shown in figure 5. The Ogallala Group (Miocene age) and the Arikaree Group (Oligocene to Miocene age) water-bearing units are present in the Cheyenne and Northern Tablelands. These units have been removed by erosion in the Pumpkin Creek and North Platte Valleys. The water-bearing units in the Ogallala and Arikaree Groups have been developed mainly for irrigation in southern Banner County and central Garden, Morrill, and Sioux Counties. The Ogallala Group consists of sandstone and gravels and can yield large amounts of water (table 1). The Arikaree Group water-bearing units mainly consist of sandstone, sand, and ash beds and yield small quantities of water (table 1). The Arikaree Group water-bearing units also are limited in areal extent and are not widely developed for irrigation purposes in the study area.

The fractured-bedrock and sand water-bearing units of the Brule Formation, located above the Chadron confining unit, are present throughout most of the study area. The fractured-bedrock and sand water-bearing units of the Brule Formation consist of brown siltstone, mudstone, fine-grained sand, and gravel. Water from the fracturedbedrock and sand water-bearing units of the Brule Formation mainly is used for irrigation and domestic purposes in some local areas in the Pumpkin Creek and North Platte Valleys. The fractured-bedrock and sand water-bearing units of the Brule Formation in these areas consist of small fluvial channel deposits of sand. The fracturedbedrock and sand water-bearing units of the Brule Formation also exhibit secondary permeability developed by fracturing of the fine-grained material.

The Chadron Formation and older undifferentiated water-bearing units of Cretaceous age are separated from the younger, shallower, water-bearing strata by the confining unit in the Chadron Formation. This confining unit consists of bentonitic mudstone and claystone. The confining unit in the Chadron Formation has not been mapped in detail and is shown only in figure 3. The water-bearing units below this regional confining unit are probably part of a deeper, regional flow system.

The oldest Tertiary water-bearing units are the water-bearing units in the confined Chadron Formation of Oligocene age. The Chadron Formation water-bearing units consist of a basal unit of sandstone and conglomerate deposited in paleovalleys that generally trend from the northwest to the southeast in the study area (DeGraw, 1969). The geographic distribution of sandstone and conglomerate in the lower part of the Chadron Formation water-bearing units is shown in figure 6. Chadron Formation water-bearing units rarely are developed for irrigation because of their depth and generally unsuitable water quality.

The oldest and deepest water-bearing units in this study are the confined Upper Lance, Fox Hills, and Pierre Shale (Transitional Zone) units of Cretaceous age, which yield small quantities of water for stock and domestic purposes in western Banner and western Scotts Bluff Counties (table 1). These undifferentiated Cretaceous hydrogeologic units were removed from the eastern part of the study area by erosion during the early Tertiary Period. The stratigraphic relations among the Upper Cretaceous hydrogeologic units are shown in the generalized geologic section in figure 3.

\section{Land Use}

Agriculture is the primary land-use activity in the North Platte NRD. According to the Agricultural Stabilization and Conservation Service, about 566,000 acres were cultivated and about 2,000,000 acres remained rangeland in 1991 (James Schild, University of Nebraska Extension, oral commun., 1992). The main dryland crop was wheat (table 2). The main irrigated crops were alfalfa, corn, dry beans, sugar beets, and wheat (table 2). Overall, about 64 percent of the cropland was irrigated in 1991.

Statistics on fertilizer use in the study area are limited to Morrill and Scotts Bluff Counties. Reported fertilizer use in both counties in 1991 was 16,474 tons total nitrogen, 6,564 tons total phosphate, and 681 tons potassium (Nebraska Agricultural Statistics Service, written commun., 


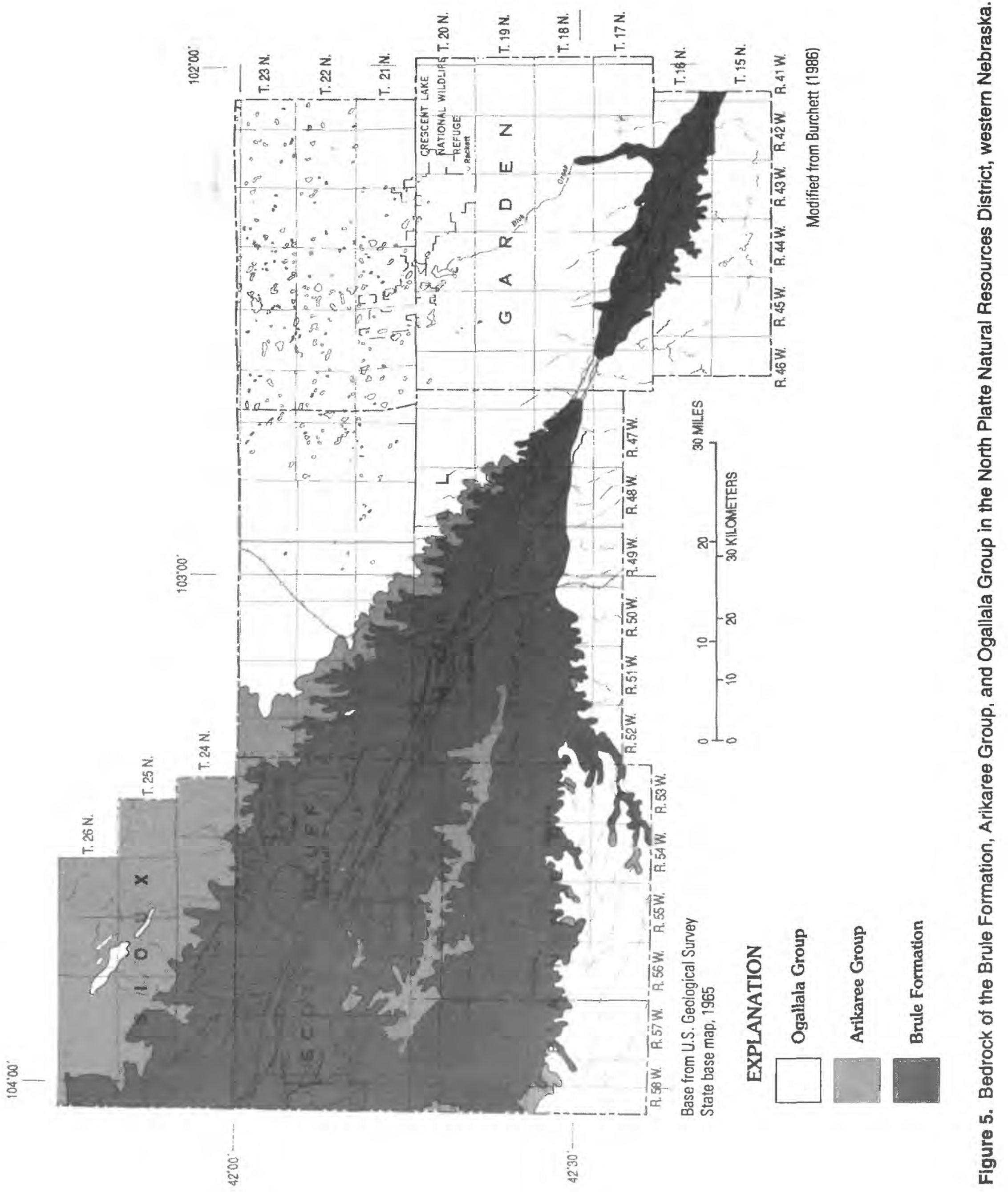




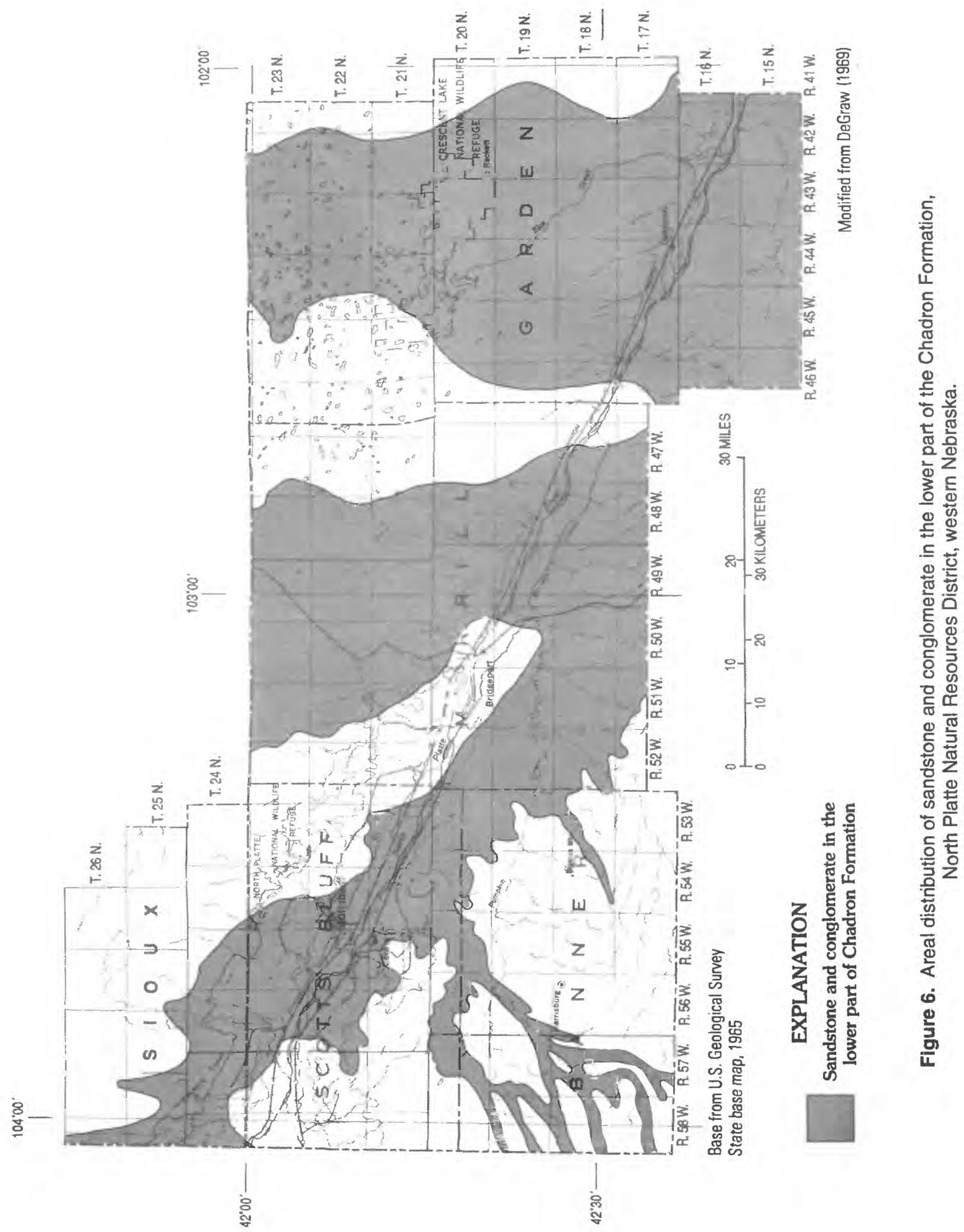


Table 2. Crop statistics for 1991 (data from Nebraska Department of Agriculture, 1993)

\begin{tabular}{|c|c|c|c|c|c|c|}
\hline \multirow[b]{2}{*}{ Crop } & \multicolumn{6}{|c|}{$\begin{array}{l}\text { Estimated number of acres } \\
\text { (in thousand acres) }\end{array}$} \\
\hline & $\begin{array}{l}\text { Banner } \\
\text { County }\end{array}$ & $\begin{array}{l}\text { Garden } \\
\text { County }\end{array}$ & $\begin{array}{l}\text { Morrill } \\
\text { County }\end{array}$ & $\begin{array}{l}\text { Scotts Bluff } \\
\text { County }\end{array}$ & $\begin{array}{l}\text { Sioux } \\
\text { County }^{2}\end{array}$ & Total \\
\hline Wheat, dryland & 61.5 & 51.7 & 29.4 & 11.3 & 6.2 & 160.1 \\
\hline Wheat, irrigated & 2.5 & 2.3 & 1.6 & .2 & .3 & 6.9 \\
\hline Corn, dryland & 0.6 & .5 & 1.5 & 1.3 & .3 & 4.2 \\
\hline Corn, irrigated & 5.9 & 15.2 & 49.1 & 66.3 & 12.2 & 148.7 \\
\hline Alfalfa, dryland & 2.3 & 1.6 & 1.5 & 1.4 & 17.2 & 24.0 \\
\hline Alfalfa, irrigated & 2.0 & 11.4 & 16.9 & 25.4 & 12.4 & 68.1 \\
\hline Dry beans, irrigated & 3.5 & 4.0 & 27.0 & 47.0 & 5.3 & 86.8 \\
\hline Sugar beets, irrigated & 2.2 & 0 & 10.0 & 38.4 & 3.3 & 53.9 \\
\hline Oats, dryland & 1.1 & 2.2 & 1.8 & 1.3 & 1.3 & 7.7 \\
\hline Barley, dryland & .9 & 1.2 & .6 & .3 & .7 & 3.7 \\
\hline Sorghum, dryland & .4 & .4 & .3 & .3 & .2 & 1.6 \\
\hline Soybeans, irrigated & 0 & .3 & 0 & 0 & 0 & .3 \\
\hline Total dryland & 66.8 & 57.6 & 35.1 & 15.9 & 25.9 & 201.3 \\
\hline Total irrigated & 16.1 & 33.2 & 104.6 & 177.3 & 33.5 & 364.7 \\
\hline Total & 82.9 & 90.8 & 139.7 & 193.2 & 59.4 & 566.0 \\
\hline
\end{tabular}

1992). Other fertilizer additions included boric acid, copper, zinc, iron, manganese, sulfate, and sodium molybdate.

Specific herbicide- and pesticide-use statistics in the North Platte NRD do not exist for 1991. In a pesticide survey conducted in 1979, 2,4-D was the most commonly used herbicide in corn, and alachlor and atrazine were less commonly used. Other herbicides used on corn were butylate, cyanazine, and metolachlor. The herbicide most commonly used on beans in western Nebraska was EPTC and trifluralin. Herbicides used on wheat in western Nebraska included 2,4-D and dicamba, whereas the herbicide most commonly used on alfalfa was benfluralin. The herbicides, insecticides, and nematocides most frequently applied in the Nebraska Panhandle are listed in table 3.

In general, corn does not receive much fungicide application. Nematocide use is limited to beets. Fumigants, such as aluminum phosphide, as well as protectants, are used on stored grain. Other chemicals include rodenticides and bird repellents (Baker and others, 1990).
Other land uses in the study area include light industry, wildlife refuges, and recreation. Industry mainly consists of agricultural processing plants, such as sugar-beet processing plants and livestock businesses. The largest livestock business in the North Platte NRD is cattle production. About 40 feedlots with more than 500 head of cattle each existed in the North Platte NRD in 1991 in addition to many smaller feedlots (James Schild, University of Nebraska Extension, oral commun., 1992). Other livestock production includes hogs and sheep. The largest wildlife refuges are the Crescent Lake National Wildlife Refuge in Garden County and the North Platte National Wildlife Refuge in Scotts Bluff County (fig. 1).

\section{Water Use}

The primary uses of ground and surface water in the study area for 1990 are listed in table 4. Water for irrigation was mainly derived from ground- and surface-water sources; about 369,000 acres were irrigated in 1990 (Zachary Hill, 
Table 3. Most frequently applied herbicides, insecticides, and nematocides on cropland in the Nebraska Panhandle

[Modified from Wilson, 1979]

\begin{tabular}{|c|c|c|}
\hline Crops & Herbicides & $\begin{array}{l}\text { Insecticides and } \\
\text { nematocides }\end{array}$ \\
\hline Corn & $\begin{array}{l}\text { 2,4-D } \\
\text { Dicamba (Banvel) } \\
\text { Some alachlor and } \\
\text { atrazine }\end{array}$ & $\begin{array}{l}\text { Terbufos (Counter) } \\
\text { Carbofuran (Furaden) }\end{array}$ \\
\hline Wheat & $\begin{array}{l}\text { 2,4-D } \\
\text { Dicamba (Banvel) }\end{array}$ & Disulfoton \\
\hline Beans & $\begin{array}{l}\text { EPTC (Eptam) } \\
\text { Ethalfluralin } \\
\text { (Sonalan) }\end{array}$ & $\begin{array}{l}\text { Carbaryl (Sevin) } \\
\text { Disulfoton } \\
\text { (Di-syston) }\end{array}$ \\
\hline Beets & $\begin{array}{l}\text { Ethofumesate } \\
\quad \text { (Nortron) } \\
\text { Cycloate (Ro-neet) }\end{array}$ & $\begin{array}{l}\text { Dichloropropene } \\
\text { (Telone) } \\
\text { Diazinon Aldicarb } \\
\quad \text { (Temik) } \\
\text { Parathion }\end{array}$ \\
\hline Alfalfa & $\begin{array}{l}\text { Benfluralin } \\
\text { (Balan) } \\
\text { Propham } \\
\text { (Chem-hoe) }\end{array}$ & $\begin{array}{l}\text { Malathion } \\
\text { Carbaryl (Sevin) }\end{array}$ \\
\hline
\end{tabular}

U.S. Geological Survey, written commun., 1992). Water-use statistics indicate that nearly six times more surface water than ground water was used for irrigation (table 4). Public- and self-supplied water use data also are listed in table 4. Public-water supplies were used mainly by municipalities to supply household needs. Self-supplied water was used mainly for irrigation. The sources of water for public-water suppliers was almost entirely ground water.

Surface water was the source of water for about 84 percent of all water used in the study area. Most of this surface water (about 67 percent) was used in Scotts Bluff County. Overall, 99 percent of surface-water use is for irrigation. Areas of intense surface-water use, represented by irrigation-use districts, are illustrated in figure 7. Surface water, regulated by the Nebraska Department of Water Resources, provided irrigation water to 339,104 acres of cropland in the study area in 1991 (T.L. Hayden, Nebraska Department of Water Resources, written commun., 1991). Surfacewater supplies are obtained from the North Platte
River and its tributaries and from extensive canal systems (fig. 7). In addition, the canal systems provide water to recreational lakes and wildlife refuges and provide storage for water used for irrigation.

Ground water in the North Platte NRD is used mainly for irrigation (an estimated 88 percent of all ground-water use in 1990). At least 236,503 acres were irrigated with ground water obtained from about 1,900 registered irrigation wells, of which 850 had center-pivot systems in the North Platte NRD (Nebraska Department of Water Resources, written commun., 1992). Water-use data for these wells are not readily available.

\section{PREVIOUS WATER-QUALITY INVESTIGATIONS}

Available data provide limited information on the major cations (calcium, magnesium, potassium, and sodium) and anions (bicarbonate, sulfate, and chloride) in ground water within the study area. The most comprehensive ground-water investigations in the study area were done for Scotts Bluff County by Wenzel and others (1946) and for a part of Morrill and Banner Counties by Durum (1952). Since 1980 , the emphasis on nonpoint-source contamination of ground water has increased, especially with respect to dissolved nitrate plus nitrite as nitrogen and pesticide concentrations (Conservation and Survey Division, 1980b). The U.S. Geological Survey (USGS) data base (WATSTORE) contained few ground-water-quality data for the North Platte NRD prior to this study.

Nebraska ground-water quality is described in publications by Engberg and Spalding (1979), Engberg (1984), and Engberg and Druliner (1987). These publications present water-quality analyses of samples from the principal aquifers of Nebraska, primarily the High Plains aquifer, which includes the Quaternary-age, the Ogallala Group, and the Arikaree Group water-bearing units, and the fractured-bedrock and sand water-bearing units in the Brule Formation. The general water chemistry of undifferentiated water-bearing units of Cretaceous age also is discussed.

Wenzel and others (1946) made a comprehensive analysis of water-quality data obtained from 36 wells in Scotts Bluff County. Water in the 

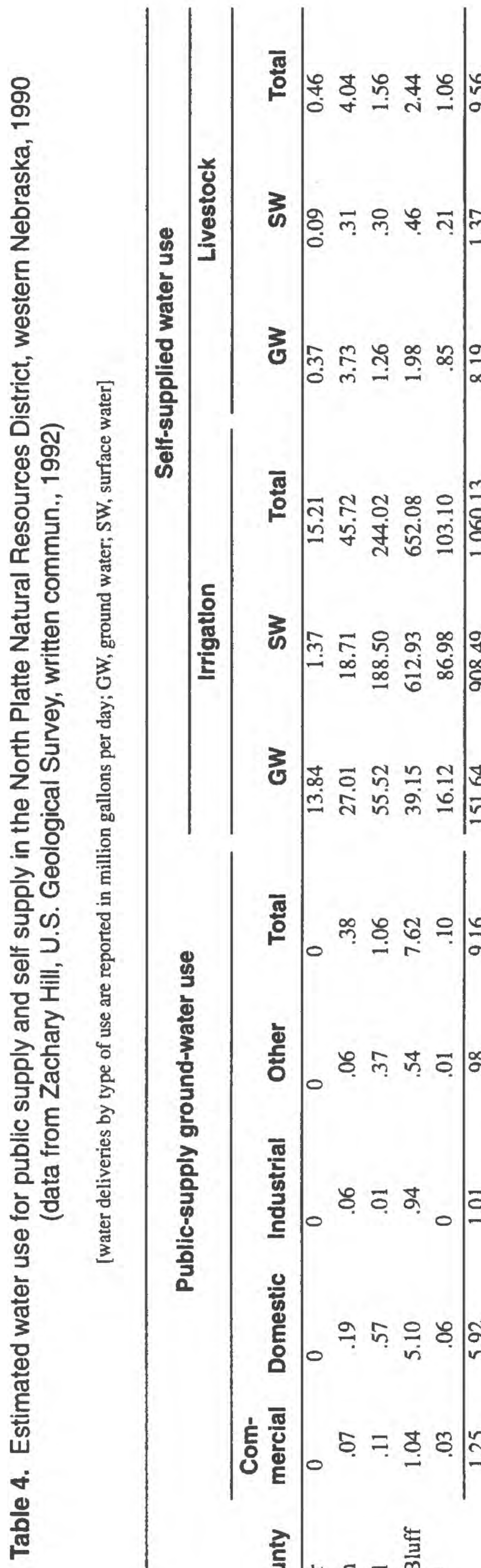

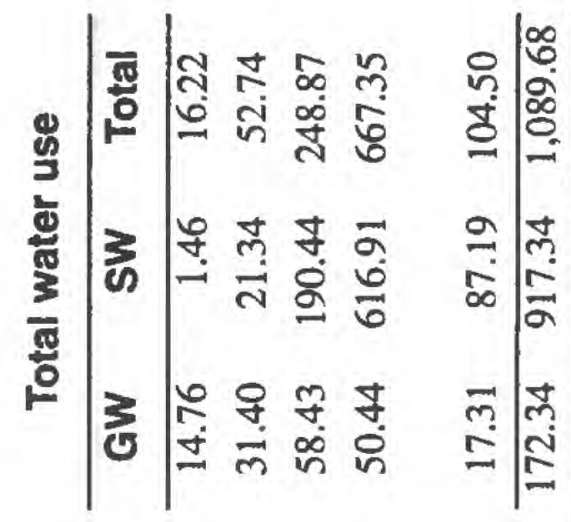

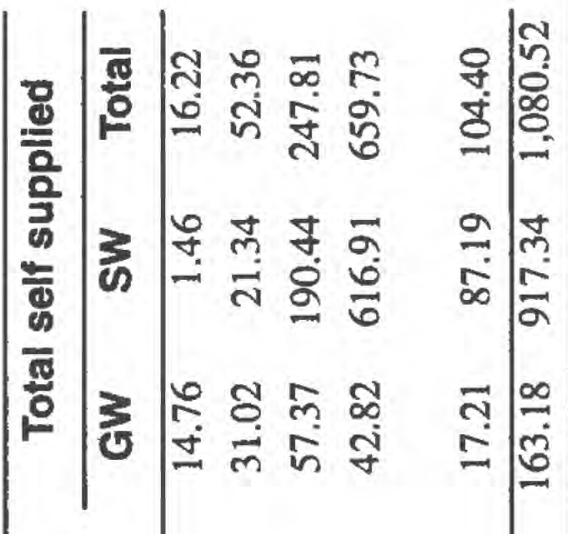

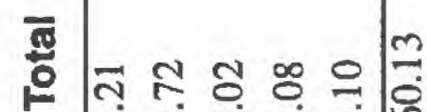

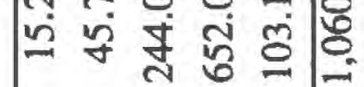

类 $\because \cong \underset{0}{-1} \infty$

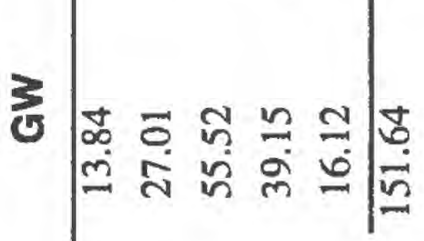

尊

|

-

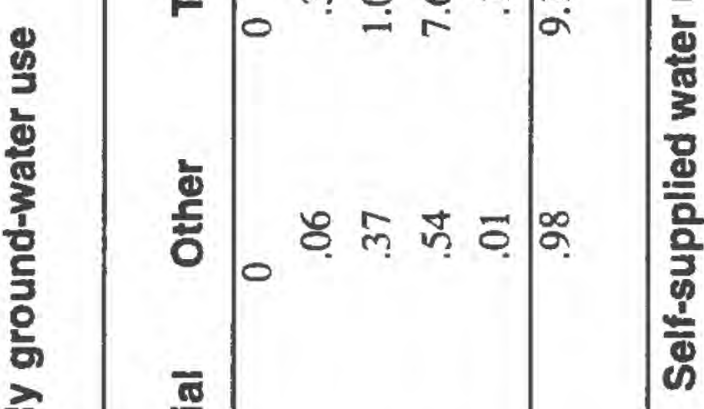

吾

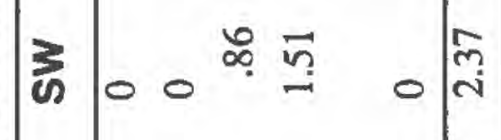

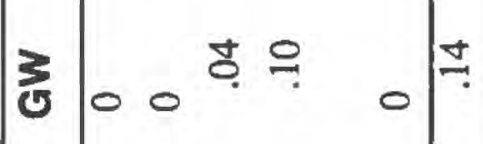

종

亲 0000000

卷

丞

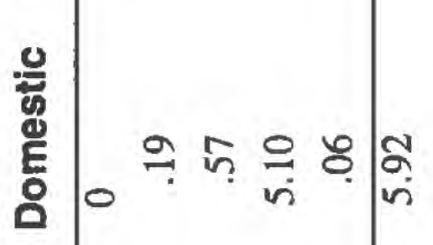

焉

党

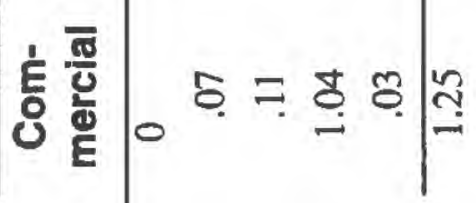

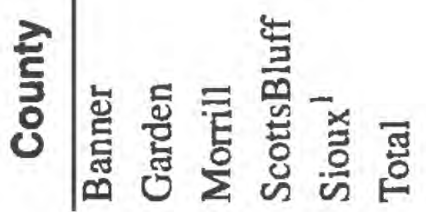

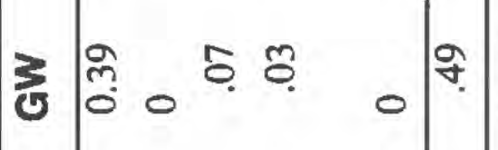

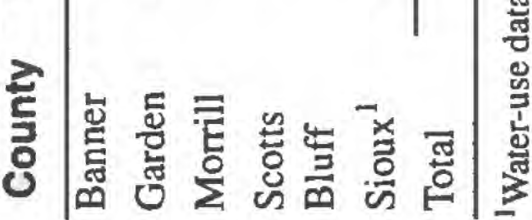




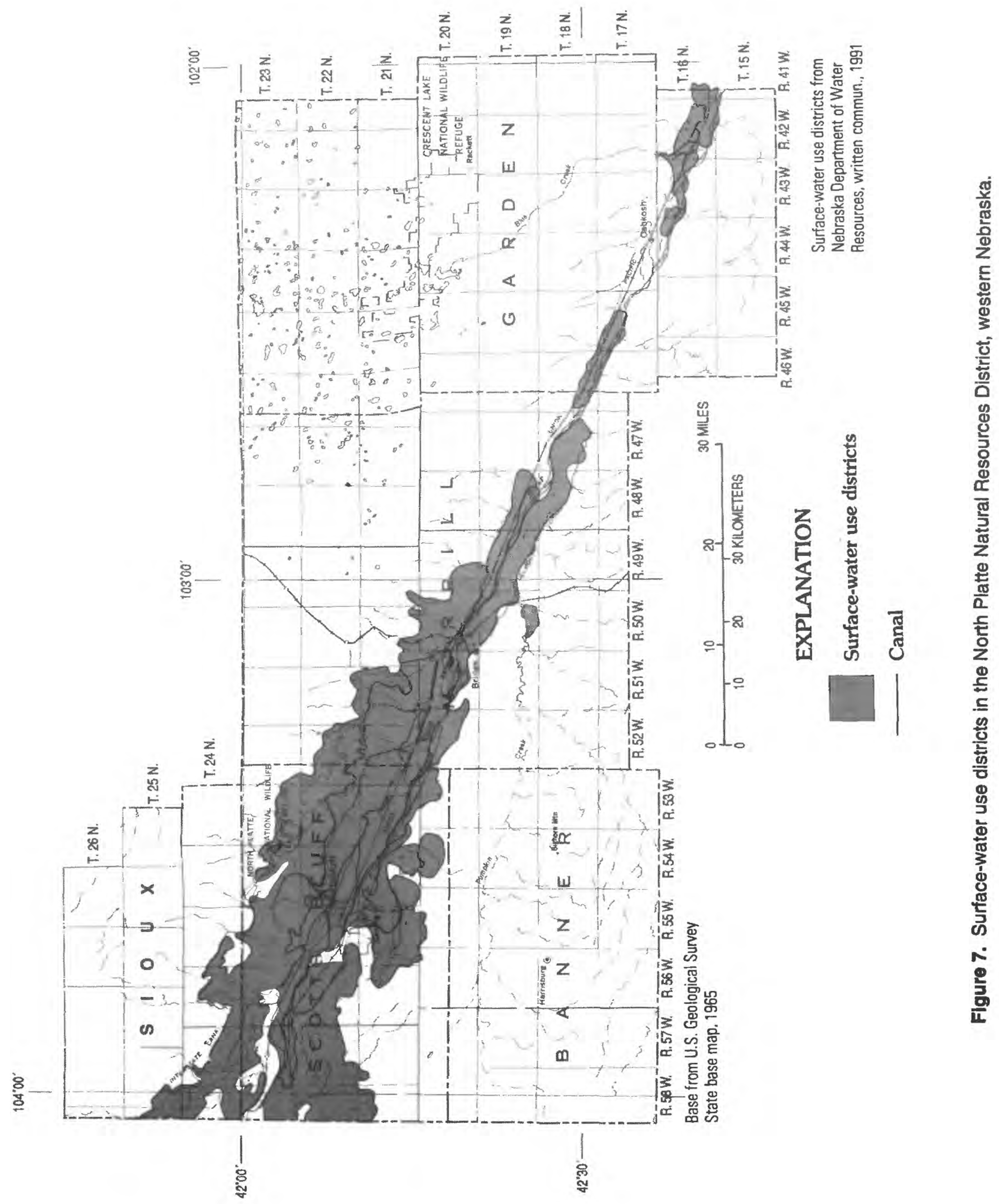


water-bearing units of Quaternary age was moderately hard and was a calcium magnesium bicarbonate type, with relatively large sulfate and small chloride concentrations. The water in the undifferentiated Cretaceous water-bearing units was considered unsuitable for irrigation because of large sodium concentrations.

Durum (1952) performed a comprehensive study of the ground-water chemistry in the Pumpkin Creek area in Morrill and Banner Counties. Durum (1952) concluded that water in the undifferentiated water-bearing units of Cretaceous age was more mineralized, softer, and less siliceous than water in overlying water-bearing units and that large chloride concentrations were an indication of the marine origin of the water. $\mathrm{He}$ also concluded that, up to the time of his study, irrigation had not adversely affected the quality of ground water in Morrill and Banner Counties. Durum (1950) also published some water-quality data for Scotts Bluff and southern Sioux Counties.

Smith and Souders (1975) determined that, in Banner County, water in the water-bearing units in the Chadron Formation was a sodium bicarbonate type and moderately hard, and that water in the fractured-bedrock and sand water-bearing units of the Brule Formation was a calcium sodium bicarbonate type with moderate hardness. Water in the overlying water-bearing units generally was characterized as a calcium bicarbonate type with moderate hardness.

Chemical analyses of ground-water samples obtained from the Arikaree Group water-bearing units and fractured-bedrock and sand waterbearing units of the Brule Formation in southern Sioux County indicated a calcium bicarbonate type water with large quantities of silica (Rainwater, 1956). The water had small boron concentrations and a small amount of sodium.

The Conservation and Survey Division of the University of Nebraska produced ground-water dissolved nitrate-as-nitrogen $\left(\mathrm{NO}_{3}-\mathrm{N}\right)$ concentration maps of the Scotts Bluff and Alliance quadrangles ( $1 \times 2$ degree series) (Conservation and Survey Division, 1980a, 1980b). The maps indicated that dissolved-nitrate concentrations generally were less than $7.6 \mathrm{mg} / \mathrm{L}$ as $\mathrm{N}$. Only 3 percent of the water samples collected in the Scotts Bluff quadrangle had dissolved-nitrate concentrations that exceeded $10 \mathrm{mg} / \mathrm{L}$ as $\mathrm{N}$. Large dissolved-nitrate concentrations were detected mainly in samples collected from shallow stock and domestic wells, which are considered more susceptible to contamination from septic tanks, barnyards, and abandoned feedlots (Conservation and Survey Division, 1980a). Exner (1990) studied increased dissolved-nitrate concentrations in the ground water of the North Platte Valley west of Oshkosh in Morrill County. The study indicated that dissolved-nitrate concentrations generally were larger than $10 \mathrm{mg} / \mathrm{L}$ in the top 40 feet of the unconfined aquifer than in water at depths greater than 40 feet; however, some dissolved-nitrate concentrations were larger at depths below 40 feet in the unconfined aquifer near irrigation wells. Exner (1990) showed that water from the Quaternary-age sediments had relatively small calculated dissolved-solids concentrations and was a calcium bicarbonate type.

The Nebraska Department of Health performed a survey throughout the State to assess problems associated with the occurrence of radiochemical elements in water from private wells (Nebraska Department of Health, written commun., 1991). Results of the survey indicated that activities of gross alpha exceeded $30 \mathrm{pCi} / \mathrm{L}$ (picocuries per liter) near the North Platte Valley in Scotts Bluff and Morrill Counties; gross alpha varied from 15.5 to $148.8 \mathrm{pCi} / \mathrm{L}$ within the study area. If gross alpha in the ground-water samples exceeded 15.0 $\mathrm{pCi} / \mathrm{L}$, the samples also were analyzed for uranium and radium. The data indicated that a uranium activity varied from 8.6 to $99.3 \mathrm{pCi} / \mathrm{L}$ and that radium activity varied from 0.1 to $0.7 \mathrm{pCi} / \mathrm{L}$. In addition, a reconnaissance of the geochemistry of ground water and streambed-sediment samples in the Scottsbluff quadrangle was done.

\section{SAMPLE COLLECTION AND LABORATORY PROCEDURES}

Standard USGS procedures were used for water-quality sampling, laboratory analyses, and quality assurance. This section represents an overview of these procedures. 


\section{Well Selection}

One hundred twenty wells were selected for sampling to describe the ground-water quality in the study area. The wells were selected on the basis of their areal distribution and completion zones relative to the water-bearing units of interest to the study. Approximately 1,990 Nebraska registration well forms were examined to obtain sample sites representative of the ground water in water-bearing units:

(1) Quaternary-age water-bearing units,

(2) Ogallala Group water-bearing units,

(3) Arikaree Group water-bearing units,

(4) Fractured-bedrock water-bearing units in the Brule Formation,

(5) Sand water-bearing units in the Brule Formation,

(6) Chadron Formation water-bearing units, and

(7) Undifferentiated water-bearing units of Cretaceous age.

A modified random approach was used to select 109 wells completed in the water-bearing units. The selection was done by water-bearing unit and by county. The number of water samples selected within a given county was a function of the number of wells within the county and the proportion of the county's surface area to the surface area of the North Platte NRD. In addition, the number of water samples collected from wells completed in each water-bearing unit in a county was a function of the number of wells within that county that were completed in the respective water-bearing unit. Onsite deviations of the sample design were unavoidable because some pre-selected wells, especially the irrigation wells, were not pumping due to climatic conditions. Because of above-normal precipitation during the time of sampling, farmers used surface water from nearby canals rather than ground water. Seventyfour wells selected for sampling were completed in the Quaternary-age water-bearing units, 13 in the Ogallala Group, 16 in the fractured bedrock of the Brule Formation, and 6 in the sand water-bearing units in the Brule Formation.

Eleven wells completed in the Arikaree Group and Chadron Formation water-bearing units and undifferentiated water-bearing units of Cretaceous age also were selected for sampling. On the basis of information from the 1,990 registration forms, only 7 wells were determined to be screened in the Arikaree Group water-bearing units, 17 in the Chadron Formation water-bearing units, and 3 in the undifferentiated water-bearing units of Cretaceous age. Because of the small number of wells completed in the Arikaree Group and Chadron Formation water-bearing units and undifferentiated water-bearing units of Cretaceous age, the modified random approach described above could not be met. As a result, the number of wells available for sampling ( 11 wells) determined the number of water samples selected from these water-bearing units (11). Water samples were collected from two welis completed in the Arikaree Group water-bearing units, six wells completed in the Chadron Formation water-bearing units, and three wells completed in the undifferentiated water-bearing units of Cretaceous age.

Of the 120 wells sampled, 101 were irrigation wells, 7 were municipal wells, 3 were industrial wells, and 9 were domestic wells. A listing of the number of wells selected in each water-bearing unit for each class of analytes is given in table 5 .

A subsample of 44 of the 120 wells was selected for more detailed analyses. Thirty-three wells were selected using the modified random approach. Again, the same sampling scheme could not be used to select wells completed in the Arikaree Group, Chadron Formation, and undifferentiated water-bearing units of Cretaceous age. Consequently, all 11 wells completed in these water-bearing units were selected for more detailed water-quality determination.

In addition, for aldicarb analyses, a subset of 42 of the 120 samples was selected at random, and 4 samples were selected from areas where aldicarb was known to be used on beets at the sample site (table 5). Finally, a subset of 30 of the 120 samples was selected at random for additional analysis of the herbicide 2,4-D and related chlorophenoxyacid compounds (table 5).

\section{Water-Quality Sampling}

Water samples from 120 wells were collected during June and July of 1991 (fig. 8 and tables 6 and 7 at the end of this report). Onsite observations included evaluation of well integrity, potential point sources-septic tanks, feedlot, industry- 
Table 5. Number of wells selected for constituent analysis by water-bearing unit

\begin{tabular}{|c|c|c|c|c|c|c|}
\hline Water- bearing units & $\begin{array}{l}\text { Dissolved } \\
\text { nitrates and } \\
\text { triazine } \\
\text { enzyme } \\
\text { assays and } \\
\text { field } \\
\text { measurements }\end{array}$ & $\begin{array}{l}\text { Major ions, } \\
\text { major metais, } \\
\text { trace } \\
\text { elements, and } \\
\text { radionuclides }\end{array}$ & $\begin{array}{l}\text { Quantitative } \\
\text { triazine } \\
\text { and } \\
\text { acetanilide } \\
\text { analyses }\end{array}$ & $\begin{array}{l}\text { Aidicarb } \\
\text { enzyme } \\
\text { assays }\end{array}$ & $\begin{array}{l}\text { Aidicarb } \\
\text { quantitative } \\
\text { anaiyses }\end{array}$ & $\begin{array}{c}\text { 2,4-D } \\
\text { immuno- } \\
\text { assays }\end{array}$ \\
\hline Quaternary age & 74 & 21 & 35 & 26 & 9 & 17 \\
\hline Ogallala Group & 13 & 5 & 2 & 1 & 1 & 1 \\
\hline Arikaree Group & 2 & 2 & 1 & 2 & 1 & 1 \\
\hline $\begin{array}{l}\text { Fractured bedrock in } \\
\text { the Brule Formation }\end{array}$ & 16 & 4 & 4 & 5 & 0 & 2 \\
\hline $\begin{array}{l}\text { Sand in the Brule } \\
\text { Formation }\end{array}$ & 6 & 3 & 2 & 3 & 0 & 1 \\
\hline Chadron Formation & 6 & 6 & 1 & 6 & 1 & 5 \\
\hline $\begin{array}{l}\text { Undifferentiated units } \\
\text { of Cretaceous age }\end{array}$ & 3 & 3 & 0 & 3 & 1 & 3 \\
\hline Total & 120 & 44 & 45 & 46 & 13 & 30 \\
\hline
\end{tabular}

prevalent land use, and determination of landsurface altitudes at each sample site. Prevalent land use and apparent potential point sources within a 1-mile radius of the sample location were noted on the field-data sheets to aid in the interpretation of anomalous water chemistry.

Water was collected from each well as close to the wellhead as possible. By using a flow-through chamber, specific conductance, $\mathrm{pH}$, water temperature, and dissolved oxygen (when sample was not collected from a gated pipe) were measured onsite at 5-minute intervals. A water sample was collected after the field measurements indicated that these water-quality properties had stabilized (typically after pumping the well for 15 to 25 minutes). The properties were considered stable upon the basis of three tolerances: specific conductance within 5 percent; $\mathrm{pH}$ within 0.1 standard unit; and water temperature within $0.2^{\circ} \mathrm{C}$. These procedures were assumed to be sufficient for collecting water samples that were representative of the water-bearing units surrounding the well screen.

At each well, a water sample was filtered immediately, preserved, and kept chilled at $4{ }^{\circ} \mathrm{C}$ prior to analyses for dissolved nitrate plus nitrite as nitrogen. An additional water sample was collected and chilled in an amber glass bottle for triazine-herbicide analysis. In addition, water from the 44 wells selected for detailed chemical analysis was sampled for concentrations of dissolved major cations and anions, major metals, trace elements, and radionuclides. All water samples were filtered and preserved onsite as described by Pritt and Jones (1989). Water samples for radon analysis were collected by use of a syringe method. Forty-six water samples were tested for aldicarb and related compounds, and 30 water samples were tested for 2,4-D and other chlorophenoxy-acid compounds.

\section{Laboratory Procedures}

Analyses for dissolved nitrate plus nitrite as nitrogen, major cations and anions, and trace elements were done at the USGS laboratory in Arvada, Colorado, in accordance with the standard methods described by Fishman and Friedman (1989). Analyses for alpha and beta radioactivity and radium-226 $\left(\mathrm{Ra}^{226}\right)$ also were done at the USGS laboratory in Arvada in accordance with USEPA methods 900.0 and 903.1 , respectively. The analyses for radon $\left(\mathrm{Rn}^{222}\right)$ were done by scintillation (Whittaker and others, 1989). The 


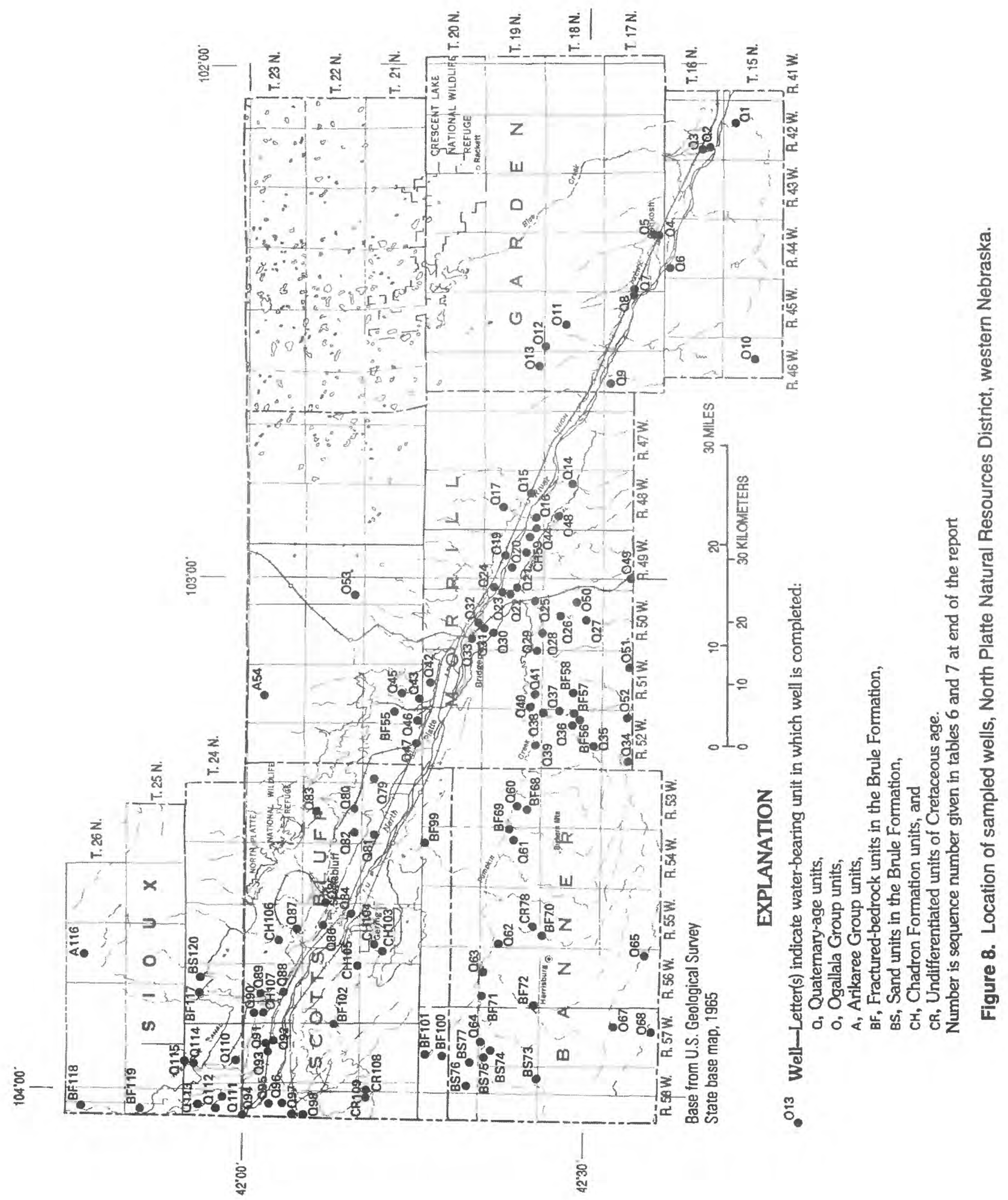


concentrations of dissolved nitrate plus nitrite, considered to be mostly dissolved nitrate under freshwater conditions and generally reported as nitrogen $(\mathrm{N})$, are referred to as such in tables 6 through 15 and are referred to as dissolved nitrate in the remainder of the text and figures. Analyses for uranium (U) concentrations and isotopic ratios of uranium-234 to uranium-238 $\left({ }^{234} \mathrm{U} /{ }^{238} \mathrm{U}\right)$ were done at the USGS laboratory in Reston, Virginia, using an isotope-dilution method (Thatcher and others, 1977).

Concentrations of the herbicides and insecticides were determined using a two-tiered approach to decrease laboratory cost. Total triazine content was estimated qualitatively using an enzyme-assay test with a differential photometer. If a water sample contained more than $0.10 \mu \mathrm{g} / \mathrm{L}$ (microgram per liter) of triazine compounds according to the enzyme-assay test, it was sent to the USGS laboratory for quantitative analysis of triazine and acetanilide herbicides using solid-phase extraction and gas chromatography/mass spectrometry (GC/MS). Analyses included alachlor, ametryn, atrazine, cyanazine, deethylatrazine, deisopropylatrazine, metolachlor, metribuzin, prometon, prometryn, propazine, and simazine.

Analyses for the herbicide 2,4-D and related chlorophenoxy-acid compounds were done semiqualitatively using an enzyme-assay test. The method used a titre-plate assembly and a plate reader with a reporting level of $0.5 \mu \mathrm{g} / \mathrm{L}$.

Similarly, water samples from 46 wells were tested qualitatively with an enzyme-assay kit for the presence of aldicarb, aldicarb sulfone, and aldicarb sulfoxide. If a water sample contained more than $1.0 \mu \mathrm{g} / \mathrm{L}$ of carbamate insecticides according to the enzyme-assay test, the water sample was analyzed for carbamate insecticides at the U.S. Geological Survey laboratory in Arvada using liquid chromatography. In total, 13 water samples were analyzed at the laboratory for carbamate insecticides, which included aldicarb, aldicarb sulfoxide, aldicarb sulfone, carbaryl, carbofuran, 3-hydroxycarbifuran, methiocarb, methomyl, 1-napthol, oxamyl, propham, and propoxur. Only four samples showed that carbamate insecticides were present according to the enzyme-assay test.

\section{Quality Control and Quallty Assurance}

The chance of unrecognized contamination of the water-quality samples, including bottles and preservatives, was reduced through quality-control measures. The quality-assurance program at the USGS laboratories includes participation in the USGS and USEPA interlaboratories evaluations and submission of blind standard reference water samples to the USGS laboratory sample stream (Friedman and Fishman, 1982; Jones, 1987). In addition, cation-anion balances were calculated for each complete analysis to ensure internally consistent data.

At least 10 percent of all enzyme-assay tests were repeated on another aliquot of water sample as a measure of the test's reproducibility. In addition, five equipment blanks were sent to the USGS laboratory in Arvada for analyses of triazine and acetanilide herbicides. Seven equipment blanks were sent to the USGS laboratory for analysis of carbamates as a quality-assurance check. Field replicates were not collected. Laboratory quality control and quality assurance for the gas-chromatographic analyses included use of standard matrix spikes, blanks, and internal blanks.

\section{DATA-ANALYSIS PROCEDURES}

Statistical analyses of water-quality data are useful tools in the identification of potential water-quality problems. For example, significant differences in the magnitude of the water-quality constituent values may indicate variations in geology, hydrology, and effect of point- and nonpoint-contamination sources among and within the water-bearing units. The data were grouped for selected statistical tests to illustrate the waterquality patterns characteristic of the water-bearing units. In addition to the statistical analyses, maps are included to illustrate the spatial distribution and regional variations of selected constituents through use of a geographic information system (GIS).

The Shapiro-Wilk test (Helsel and Hirsch, 1992) rejected (alpha $=0.05$ ) the hypotheses of normality for all water-quality variables of interest to this study, except for radium-226. Water-quality data typically show asymmetrical distributions or are said to be skewed. Skewness is readily 
observed in boxplots illustrating the asymmetric distribution of the data around a mean or median. Therefore, nonparametric statistical analyses were used for data analyses in this report. Nonparametric statistics are techniques that generally are not sensitive to outlying values and do not require stringent assumptions such as normality.

Other analyses included are statistical summaries and boxplots. The boxplots are used to summarize graphically the variability of the constituents by water-bearing units and by county. Outliers, values located outside the boxes and whiskers of the boxplots, may indicate unusual hydrologic conditions, such as local mineralogical differences within the water-bearing units or the effects of seepage from an external source such as a canal, a cattle operation, or a landfill.

Hypothesis tests were used to evaluate whether differences in the data could be explained by random variability alone. The tests involved the formulation of null and alternate hypotheses, where the null hypothesis was that the populations were identical. Caution should be exercised in drawing broad conclusions about the statistical results due to the small sample size from several water-bearing units analyzed.

The Spearman rank correlation (Helsel and Hirsch, 1992), a nonparametric correlation procedure that involves ranks of data rather than the actual data values, was used to identify the degree of association among water-quality constituents of all water-bearing units. By using an alpha level of 0.001 , correlation coefficients (r) larger than 0.49 and smaller than -0.49 for a sample size of 44 and larger than 0.30 and smaller than -0.30 for a sample size of 120 were considered significantly correlated.

The large-sample-approximation KruskalWallis test (Helsel and Hirsch, 1992), a nonparametric analysis of variance procedure that involves ranks of data rather than the data values, was used to determine whether differences existed among the water quality of the water-bearing units under study (table 16 at the end of the report). The probability (given as a p value) that represents the attained significance level ( $p$ value) is presented in the first column of table 16 . If the $p$ value is smaller than or equal to a preselected alpha value, the null hypothesis is rejected; hence, the distribution of concentrations was not the same in all the water-bearing units. The test determines that the distribution of concentrations in at least one waterbearing unit is different from the others, but not in which one(s). In this report an alpha level of 0.001 was selected for data interpretation.

Tukey's test, (Helsel and Hirsch, 1992), was used in the data interpretation if the $p$ value of the Kruskal-Wallis test was less than 0.001 (table 17 at the end of the report). Tukey's test determined which water-bearing units had significantly different distributions of concentrations and assigned groups of water-bearing units with similar distributions of concentrations. After completion of this procedure, the Wilcoxon Rank Sum test, the Kruskal-Wallis test for only two groups, was performed. The Wilcoxon Rank Sum test was performed on data collected from groups of water-bearing units on the basis of known geohydrologic differences between the water-bearing units, for example, water data collected from confined water-bearing units compared to all other units (last four columns in table 16).

A simple substitution method was used to include censored data, also called "less thans" in the statistical analyses. All values less than the detection level were considered to be zero for the Shapiro-Wilk test and the creation of boxplots. Substitution of zeros for censored data was not done for the nonparametric tests because all censored data are represented by ranks tied at values lower than the lowest rank above the detection limit.

\section{GROUND-WATER QUALITY}

This section addresses the quality of the principal ground water used in the study area, including selected nutrients, organic pesticides, major elements, major metals and trace elements, radionuclides, and related health concerns. The discussion focuses on the areal and vertical differences in water quality and describes suitability of use for drinking water and irrigation. The discussion also relates the chemistry of the water to the minerals present in the soil and unsaturated and saturated deposits.

All water-quality data are reported in tables 6 and 7 at the end of the report. A statistical summary of the data and summary by water- 
bearing unit, except herbicide and insecticide data, is presented in tables 8 through 15 at the end of the report. Drinking-water regulations and criteria established by the USEPA to safeguard public health and welfare also are included in tables 8 through 15. In addition, the USGS's National Water Information System (NWIS) and Water Data Storage and Retrieval (WATSTORE) data bases contain all of the water-quality data.

\section{Nitrate and Selected Organic Pesticides}

\section{Nitrate}

One of the purposes of the study was to evaluate the effect of agricultural practices on water quality within the study area. Durum (1952) suggested that irrigation had not affected the water quality in the Pumpkin Creek area. Dissolved nitrate probably is the contaminant most frequently encountered in rural areas because of its relatively large leaching potential. As a component of fertilizer, it is applied on cropland, especially irrigated cropland in areas with shallow waterbearing units (Spalding, 1991). In general, shallow ground water can be affected by solutes transported through the unsaturated zone from the land surface.

The dissolved-nitrate concentrations presented in this report are expressed in terms of equivalent elemental nitrogen $(\mathrm{N})$ content. Dissolved-nitrate concentrations are converted to the equivalent nitrogen by dividing the dissolved-nitrate concentration by 4.43 . The dissolved-nitrate concentrations in this study varied from less than the detection level $(0.05 \mathrm{mg} / \mathrm{L}$ as $\mathrm{N})$ to $19.0 \mathrm{mg} / \mathrm{L}$ as $\mathrm{N}$, with a median of $4.1 \mathrm{mg} / \mathrm{L}$ as $\mathrm{N}$ and a standard deviation of 3.24 (table 8). The areal distribution of dissolved-nitrate (as nitrogen) concentrations is shown in figure 9. Boxplots that show the differences in dissolved-nitrate-concentration distributions by water-bearing unit and by county, and the distribution of well depths by waterbearing unit are shown in figure 10 . The summary statistics of dissolved-nitrate concentrations for each water-bearing unit and respective well depths are given in tables 9 through 15 .

The tables and boxplots indicate that the largest median dissolved-nitrate concentrations (greater than $4.0 \mathrm{mg} / \mathrm{L}$ as $\mathrm{N}$ ) are found in water from the Quaternary-age water-bearing units and both fractured-bedrock and sand water-bearing units in the Brule Formation. All three waterbearing units have shallow well depths (median depths of 84, 100, and 125 feet, respectively) and are in areas along Pumpkin Creek and the Platte River where both ground- and surface-water irrigation is most intense. Water from wells that are completed in the Chadron Formation and undifferentiated water-bearing units of Cretaceous age and that have median well depths of 460 and 305 feet, respectively, have median dissolvednitrate concentrations less than the detection level ( $0.05 \mathrm{mg} / \mathrm{L}$ as $\mathrm{N}$ ).

Data from tables 9 through 15 and results from the Kruskal-Wallis test (table 16) indicate that the distribution of concentrations of dissolved nitrate was not the same in all water-bearing units. Results from Tukey's test (Helsel and Hirsch, 1992) (table 17) indicate that water from the Quaternary-age, Ogallala Group, and Arikaree Group water-bearing units and fractured-bedrock and sand water-bearing units in the Brule Formation do not have the same distribution of dissolved-nitrate concentrations. The Wilcoxon Rank Sum test (table 16) indicates that the distribution of concentrations of dissolved nitrate in the Quaternary-age water-bearing units was different than the distribution in the other water-bearing units. Similarly, the Wilcoxon Rank Sum test indicated that the distribution of concentrations of dissolved nitrate in the Chadron Formation and undifferentiated Cretaceous-age water-bearing units was different than the distributions in the other aquifers.

Less than one-fourth of the water samples (27 of 120) have dissolved-nitrate concentrations greater than $6.0 \mathrm{mg} / \mathrm{L}$ as $\mathrm{N}$. Boxplots of dissolvednitrate concentration by county (fig. 10) show that median dissolved-nitrate concentrations are equal to or less than $5.0 \mathrm{mg} / \mathrm{L}$ as N. Garden County, the county with the least number of irrigated acres within the North Platte NRD, has the smallest median dissolved-nitrate concentration. The wells that produce ground water with dissolved-nitrate concentrations greater or equal to $5.0 \mathrm{mg} / \mathrm{L}$ as $\mathrm{N}$ (fig. 9) correspond mainly to areas with large numbers of irrigation wells, surface-water use districts (fig. 7), and the shallowest wells. In these areas, the Quaternary-age water-bearing units and fractured-bedrock and sand water-bearing units in 


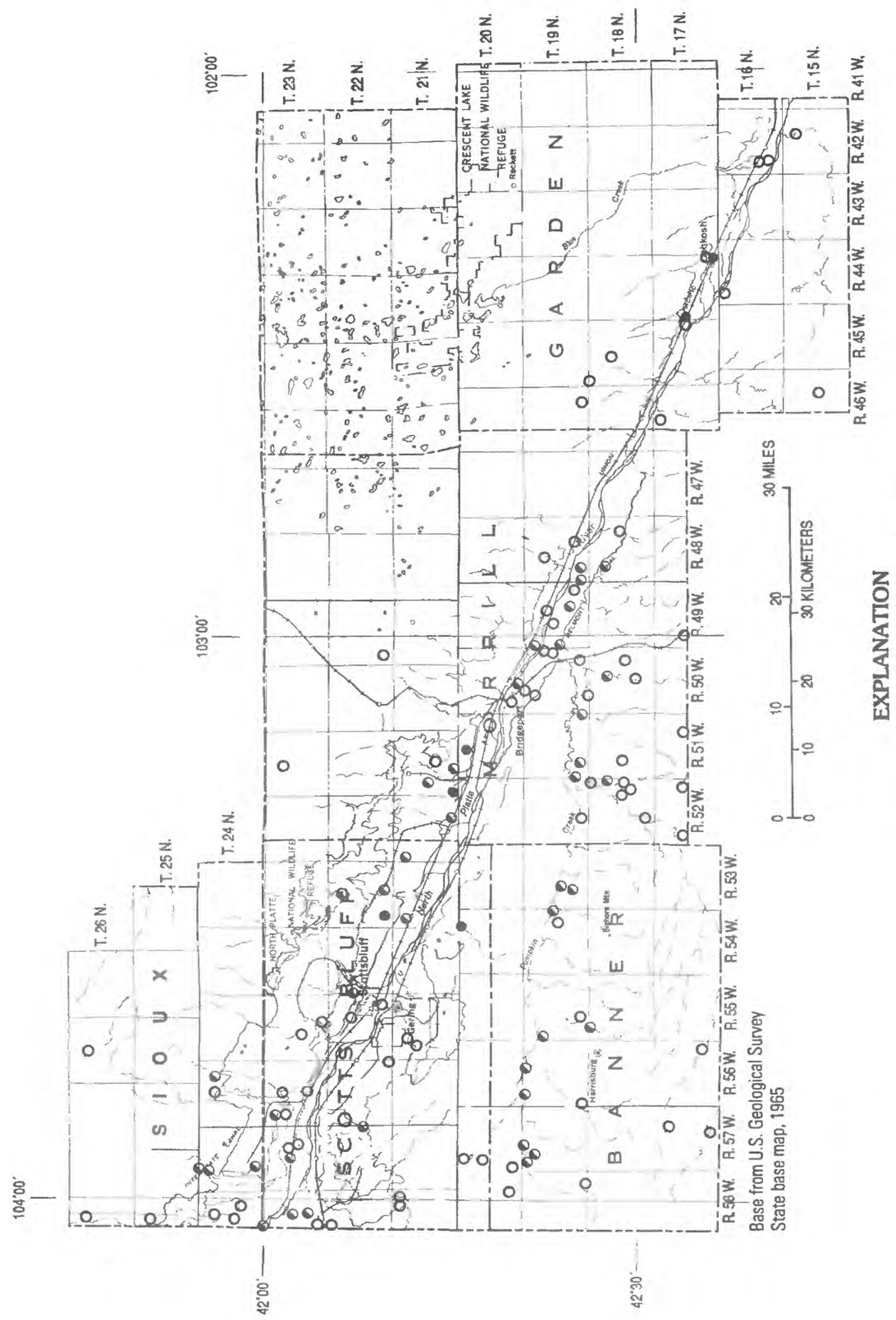

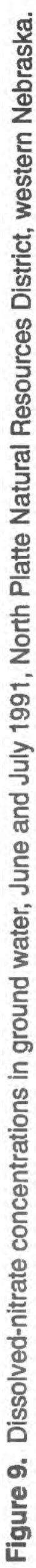



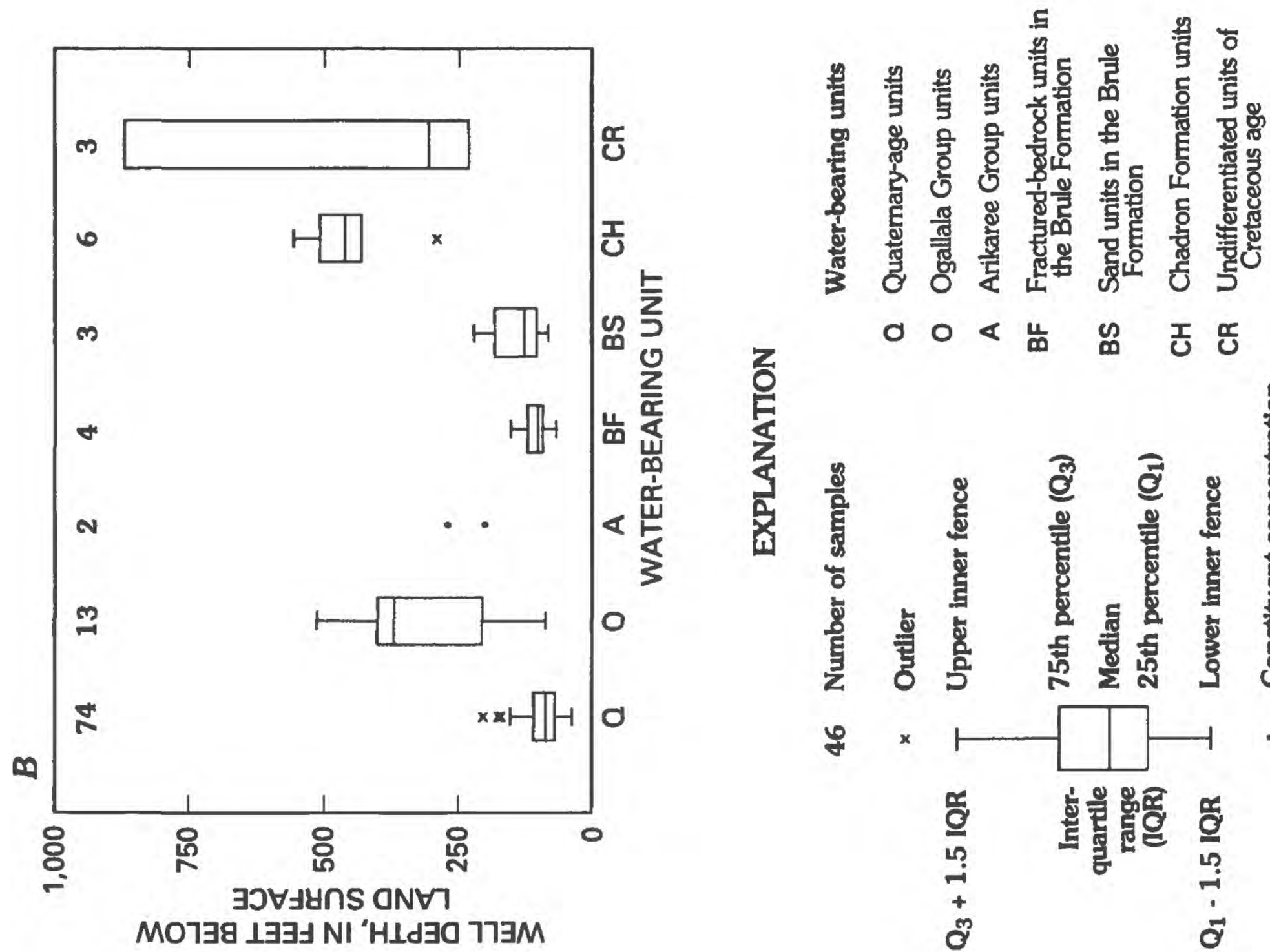

$00<$ 㟧留 工无
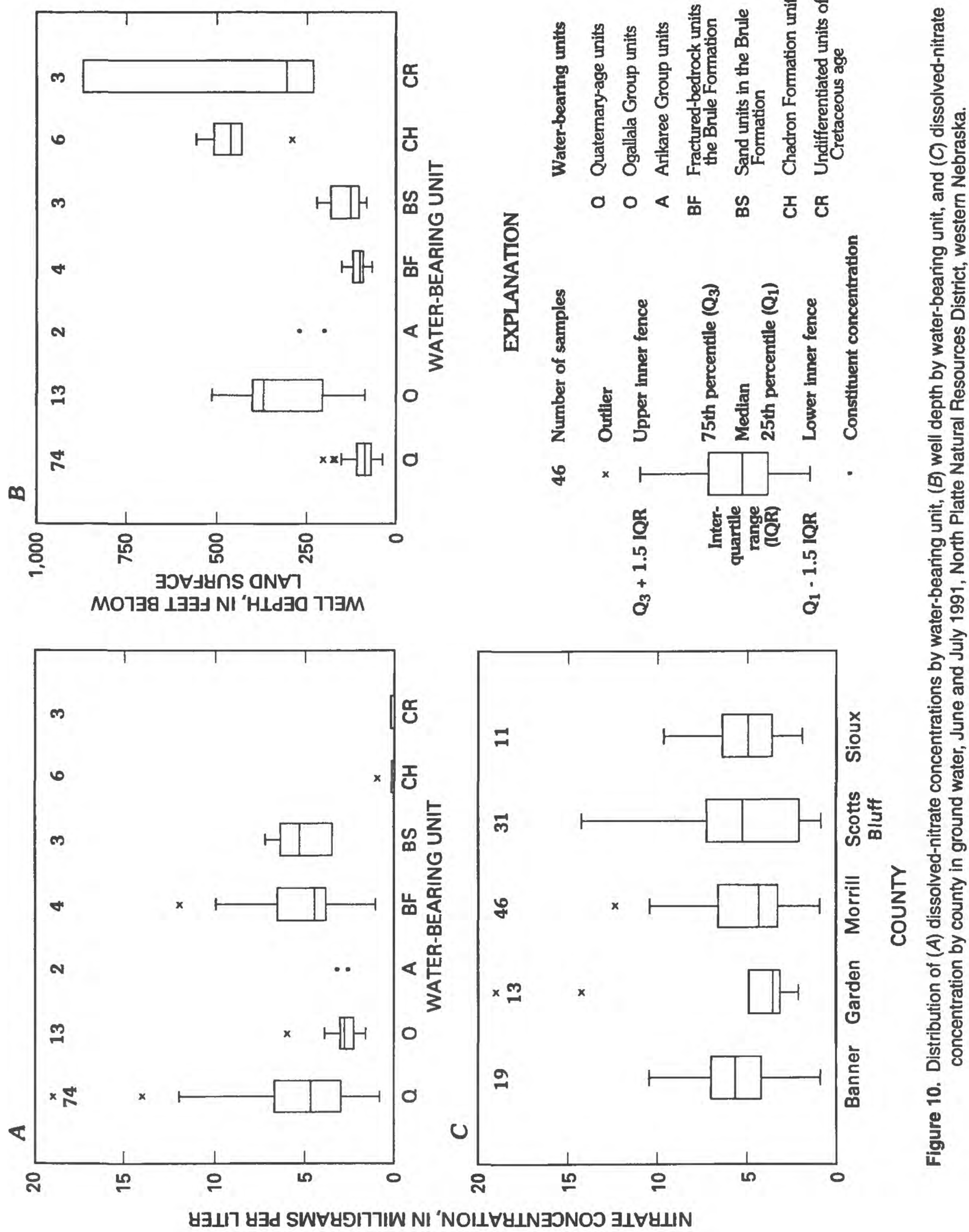

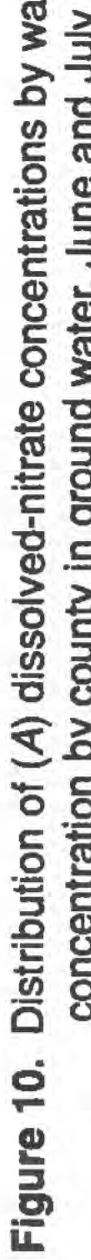


the Brule Formation are the primary ground-water sources. Where both Quaternary-age waterbearing units and fractured-bedrock and sand water-bearing units in the Brule Formation are present, hydraulic connection exists between the units. Many irrigation wells in Scotts Bluff and Banner Counties have a continuous screen through both these units. The larger dissolved-nitrate concentrations are in ground water in areas with generally small to intermediate soil permeability in the bottomlands, which have been cultivated longer. This indicates that small to intermediate soil permeability in the North Platte NRD does not prevent contaminants from reaching the shallow water-bearing units, provided that enough time has elapsed since the beginning of application of fertilizer on the land surface.

The scatterplot of dissolved nitrate as nitrogen as a function of depth shows that only ground water obtained from wells less than 200 feet deep contained dissolved-nitrate concentrations greater than $10 \mathrm{mg} / \mathrm{L}$ as $\mathrm{N}$ (fig. 11). Smaller dissolvednitrate concentrations in the Chadron Formation water-bearing units and undifferentiated waterbearing units of Cretaceous age (fig. 10) can be explained by the reduced leaching of dissolved nitrates at depth due to the presence of confining layers or by denitrification under reducing conditions in the deeper layers.

Even though dissolved nitrate can originate from natural sources such as mineralization of soil organic matter and from other sources such as domestic effluent from septic systems and animal waste, most large dissolved-nitrate concentrations in the ground water in rural areas are related to the application of fertilizers on cropland (Spalding and others, 1978; Gormly and Spalding, 1979;

Spalding and Kitchen, 1988; Hallberg, 1989). Other studies have shown that large dissolvednitrate and sulfate concentrations are probably a result of addition of solutes associated with soil amendments (Spalding and Exner, 1980). The data collected for this study indicate that dissolvednitrate and sulfate concentrations are positively correlated $(r=0.65)$.

The MCL of $10 \mathrm{mg} / \mathrm{L}$ as $\mathrm{N}$ for dissolved nitrate was exceeded in the ground water obtained from six wells (table 6). These instances may have resulted from use of nitrogen fertilizers (wells Q4, Q7, Q42, Q46, BF99, Q83 with $14.0 \mathrm{mg} / \mathrm{L}$,

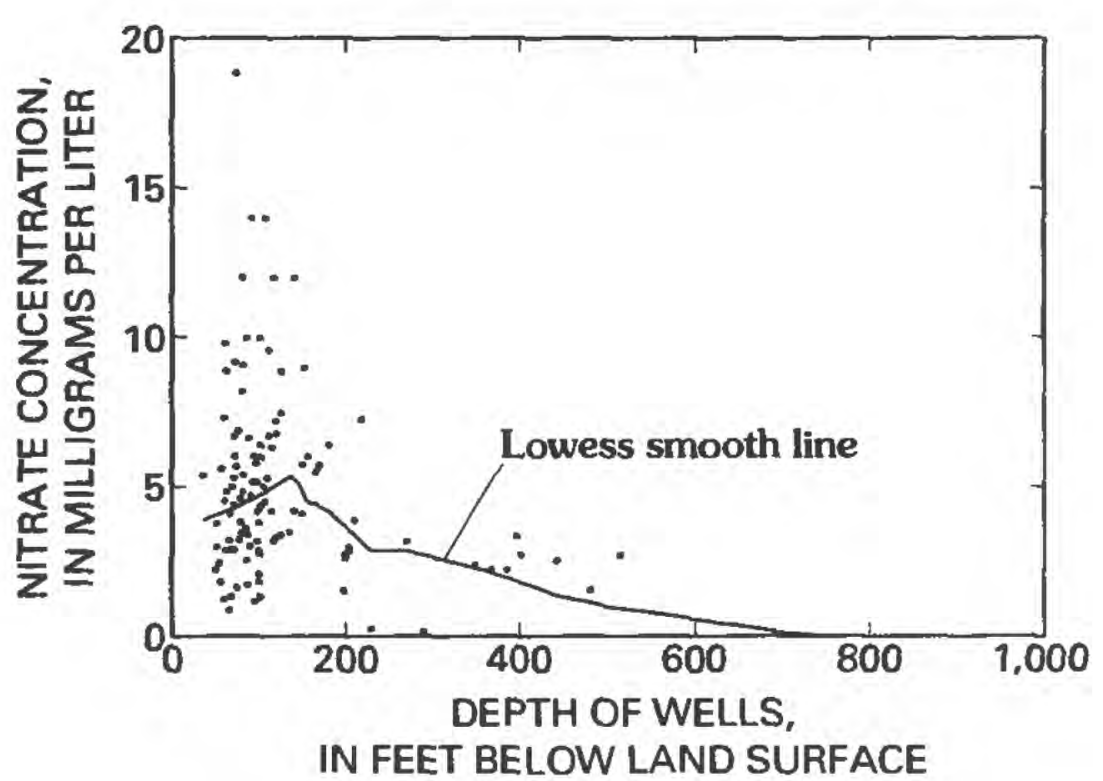

Figure 11. Relation between dissolved-nitrate concentration in ground-water samples and well depth, North Platte Natural Resources District, western Nebraska.

$19.0 \mathrm{mg} / \mathrm{L}, 12.0 \mathrm{mg} / \mathrm{L}, 12.0 \mathrm{mg} / \mathrm{L}, 12.0 \mathrm{mg} / \mathrm{L}$, and $14.0 \mathrm{mg} / \mathrm{L}$ as $\mathrm{N}$, respectively). These irrigation wells are completed in the Quaternary-age water-bearing units, except well BF99, which is screened in the fractured-bedrock water-bearing units in the Brule Formation. The depths of the wells with water containing large dissolved-nitrate concentrations range from 70 to 140 feet.

\section{Selected Organic Pesticides}

Enzyme-assay testing for triazine herbicides and metabolites (120 water samples) and carbamate insecticides (46 water samples) resulted in 28 and 6 detections, respectively. Enzyme-assay analyses did not detect 2,4-D and other chlorophenoxy-acid compounds including 2,4-D methyl ester, 2,4-D isopropyl ester, dichlorprop, 2,4,5,-T, and MCPA (table 6). Follow-up quantitative analyses for the triazine herbicides and carbamate insecticides resulted in eight atrazine detections (wells Q4, Q7, Q8, Q21, Q42, O53, Q80, and Q83) with a maximum concentration of $0.47 \mu \mathrm{g} / \mathrm{L}$, three deethylatrazine detections - a degradation product of atrazine - (wells BF55, Q80, and Q88) with a maximum concentration of $0.18 \mu \mathrm{g} / \mathrm{L}$, two prometon detections (wells $\mathrm{Q} 31$ and $\mathrm{Q} 88$ ) with a maximum concentration of $0.07 \mu \mathrm{g} / \mathrm{L}$, one alachlor detection (well Q110) with a concentration of 
$0.11 \mu \mathrm{g} / \mathrm{L}$, and no carbamate detections (table 6). The minimum and median concentrations of all herbicides and insecticides are below the detection levels. As a result, summary statistics of these constituents are not listed in tables 8 through 15 . All but one herbicide detection were located within the North Platte Valley (fig. 12). All detections were less than the proposed MCLs of $2.0 \mu \mathrm{g} / \mathrm{L}$ for alachlor and $3.0 \mu \mathrm{g} / \mathrm{L}$ for atrazine (U.S. Environmental Protection Agency, 1988a). The USEPA has not established MCL's for the remainder of the herbicides detected.

The atrazine and acetanilide concentrations analyzed in the laboratory during this study varied from less than the detection level of 0.05 to $0.47 \mu \mathrm{g} / \mathrm{L}$ (table 6). Atrazine detections correspond to dissolved-nitrate concentrations ranging from 1.7 to $19 \mathrm{mg} / \mathrm{L}$ as $\mathrm{N}$ and well depths less than 150 feet deep. Statistical analysis did not show a significant correlation between dissolved-nitrate concentrations and triazine detections.

Seven ground-water samples collected from the Quaternary-age water-bearing units and one ground-water sample collected from the Ogallala Group water-bearing units contained detectable atrazine. Overall, the detections of triazines (fig. 12) in ground water were from wells in irrigated areas within the North Platte Valley, specifically in an area surrounding Oshkosh in Garden County and between Bridgeport and Scottsbluff in Banner and Scotts Bluff Counties. All detections of alachlor, deethylatrazine, and prometon were in water samples from irrigation wells, except well Q88, which is a municipal well. All these wells have depths less than 130 feet. Additional information on the distribution of land and pesticide use would help in understanding relations among these water-quality variables and agricultural practices.

\section{Major Cations and Anions, pH, Dissolved Oxygen, Specific Conductance, and Calculated Dissolved Solids}

\section{Major Cations and Anions and Water Types}

\section{General Statistical Analytical Results}

Relations among the water-quality constituents, well depth, and water temperature were determined using the Spearman rank correlation analysis. Significant positive correlations among major cations, bicarbonate (assumed to be the major component of alkalinity), and sulfate may indicate common mineral sources. Constituents with significant positive correlations are magnesium, potassium, and sulfate with calcium ( $r=0.92, r=0.71$, and $r=0.78$, respectively), sodium with chloride $(r=0.81)$, and magnesium and potassium with sulfate $(r=0.80$ and $r=0.58$, respectively). In addition, the relatively large concentrations of potassium and sulfate in some water samples collected from wells completed in Quaternary-age water-bearing units could indicate nonpoint-source contamination or may be related to the geochemistry of the water-bearing units. Geochemical modeling and mineral and chemical analyses of the geologic strata would aid in interpretation of these relations. The data do not indicate changes in the water quality with depth within the Quaternary-age water-bearing units; this could be the result of the large numbers of irrigation wells or of rapid flow of water into or within the Quaternary-age water-bearing units, both increasing the mixing of water.

Overall, the nonparametric statistical analyses (table 16) and illustrations (figs. 13 and 14) indicate differences in the chemistry of water among the Quaternary-age and Chadron Formation water-bearing units, and undifferentiated waterbearing units of Cretaceous age. The KruskalWallis test (Helsel and Hirsch, 1992) was used to identify differences between water-quality constituents by water-bearing unit (table 16). This test indicated that the distribution of concentrations was not the same in all water-bearing units for all constituents discussed in this section except potassium, sulfate, and chloride.

Subsequent testing with Tukey's test (table 17) indicated that water from the Chadron Formation water-bearing units and undifferentiated waterbearing units of Cretaceous age had different concentrations of alkalinity and sodium than water from the other water-bearing units. Further, Tukey's test indicated that water from the Chadron Formation water-bearing units and undifferentiated water-bearing units of Cretaceous age had a different sodium-adsorption ratio than water from the other units. Tukey's test also indicated that water from the water-bearing units in the Brule Formation, Chadron Formation water-bearing 


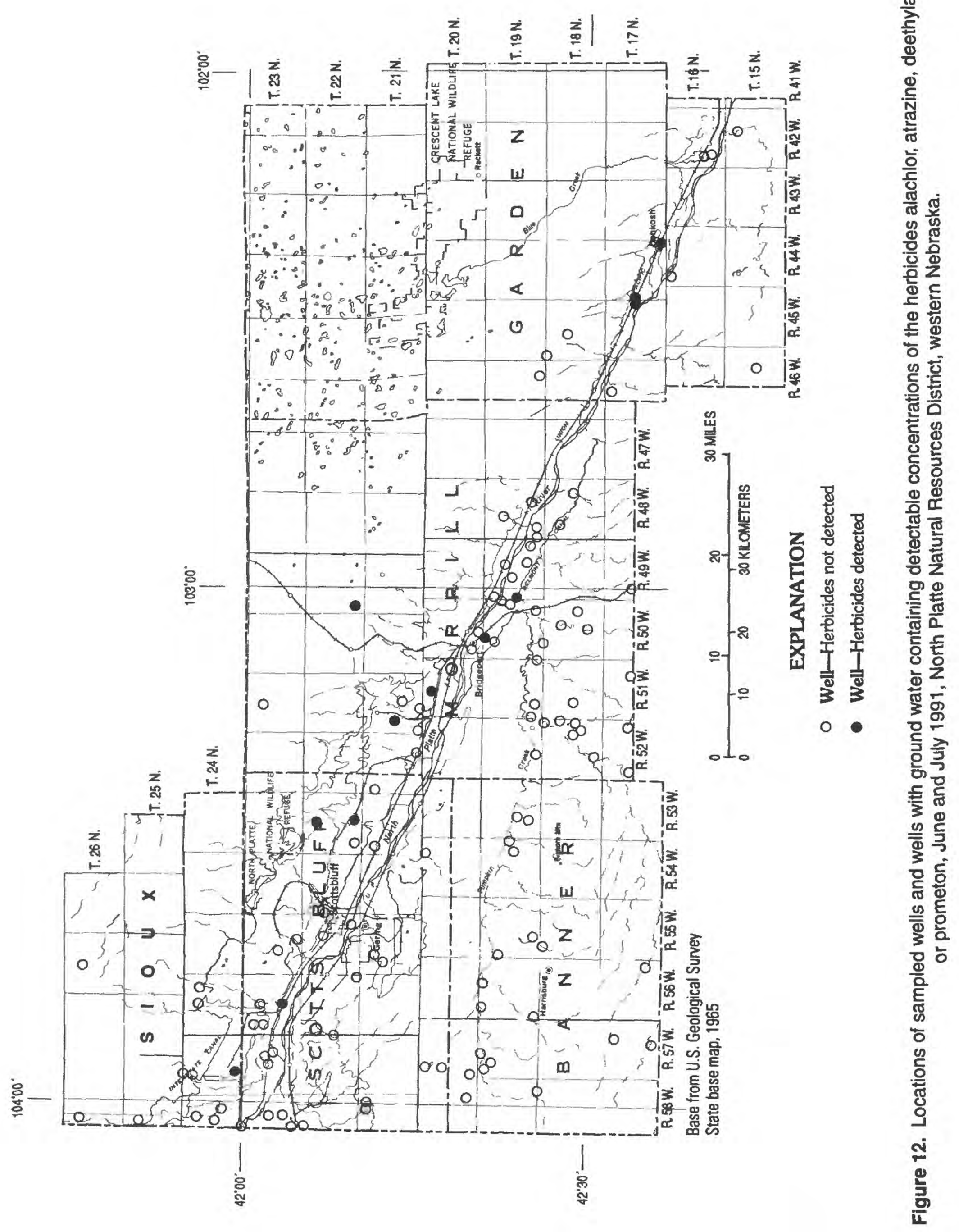



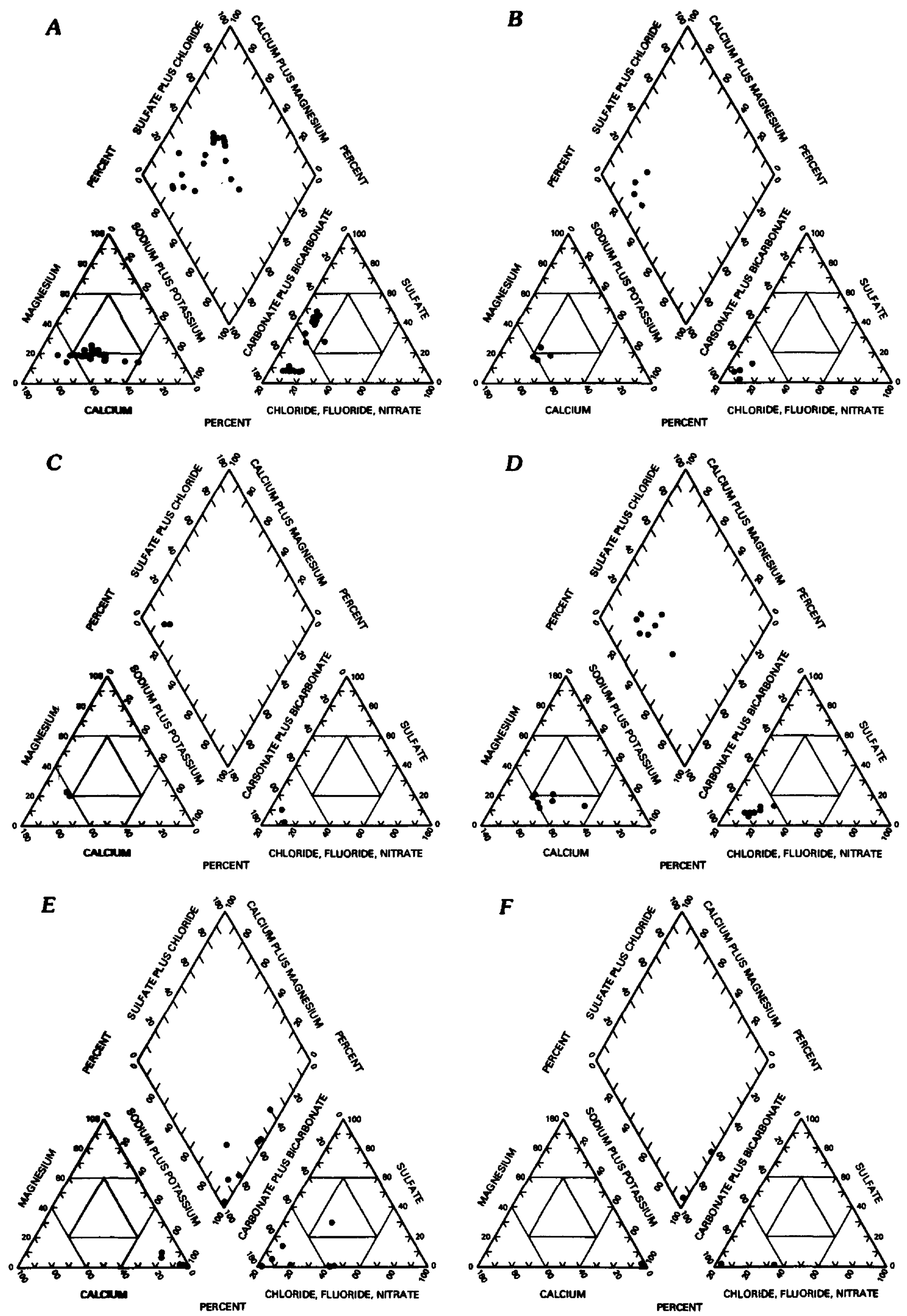

PERCENTAGE OF TOTAL, IN MILLIEQUIVALENTS PER LITER

Figure 13. Ionic composition of ground water by water-bearing unit, North Platte Natural Resources District, western Nebraska: $(A)$ Quaternary-age water-bearing units; $(B)$ Ogallala Group water-bearing units; $(C)$ Arikaree Group water-bearing units; $(D)$ fractured-bedrock and sand water-bearing units in the Brule Formation; $(E)$ Chadron Formation water-bearing units; and $(F)$ undifferentiated water-bearing units of Cretaceous age. 

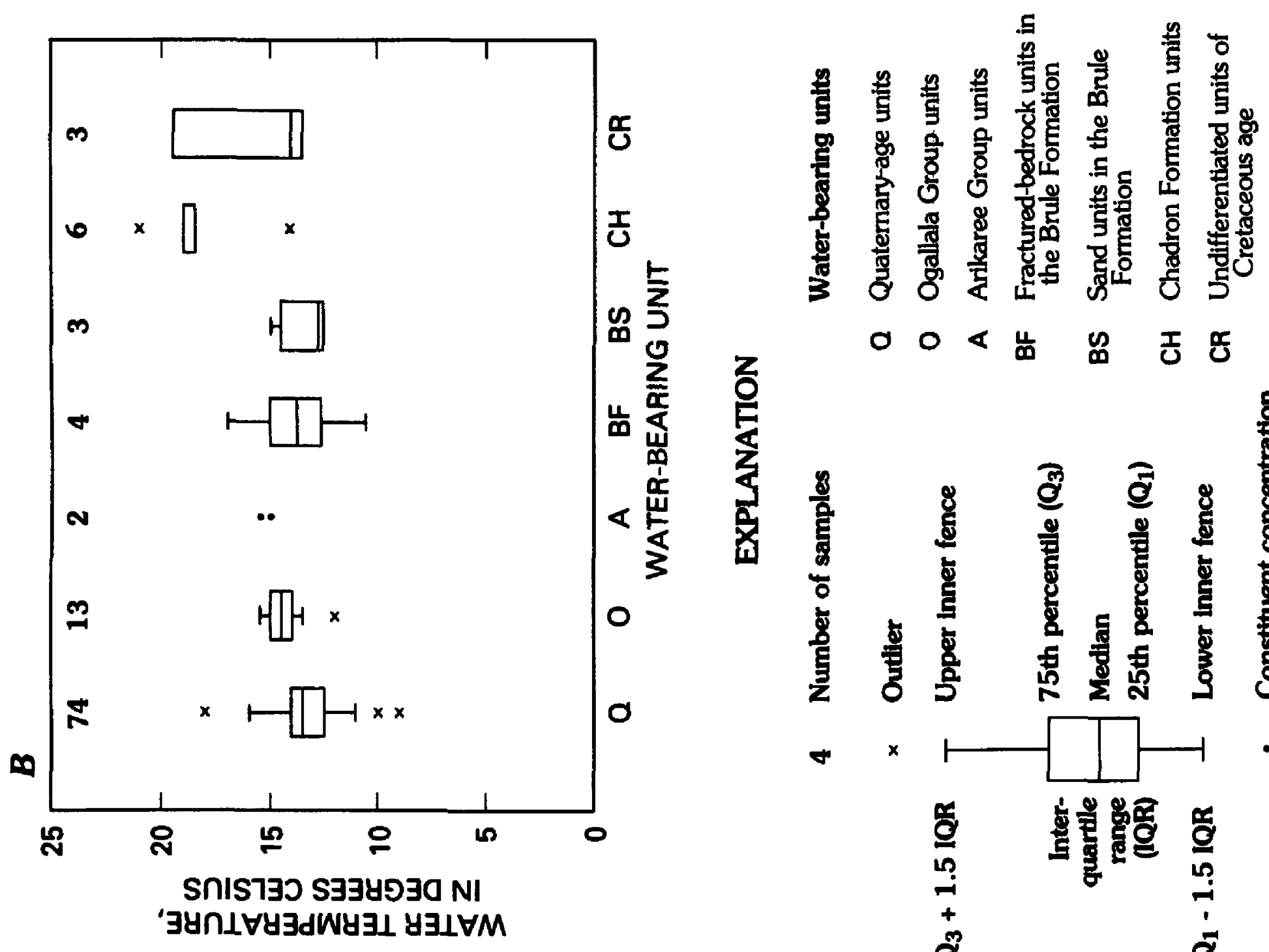

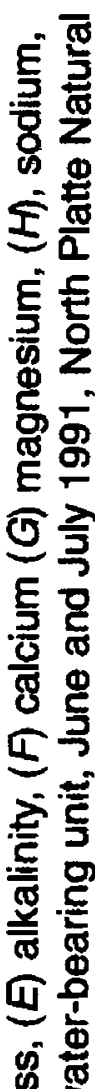
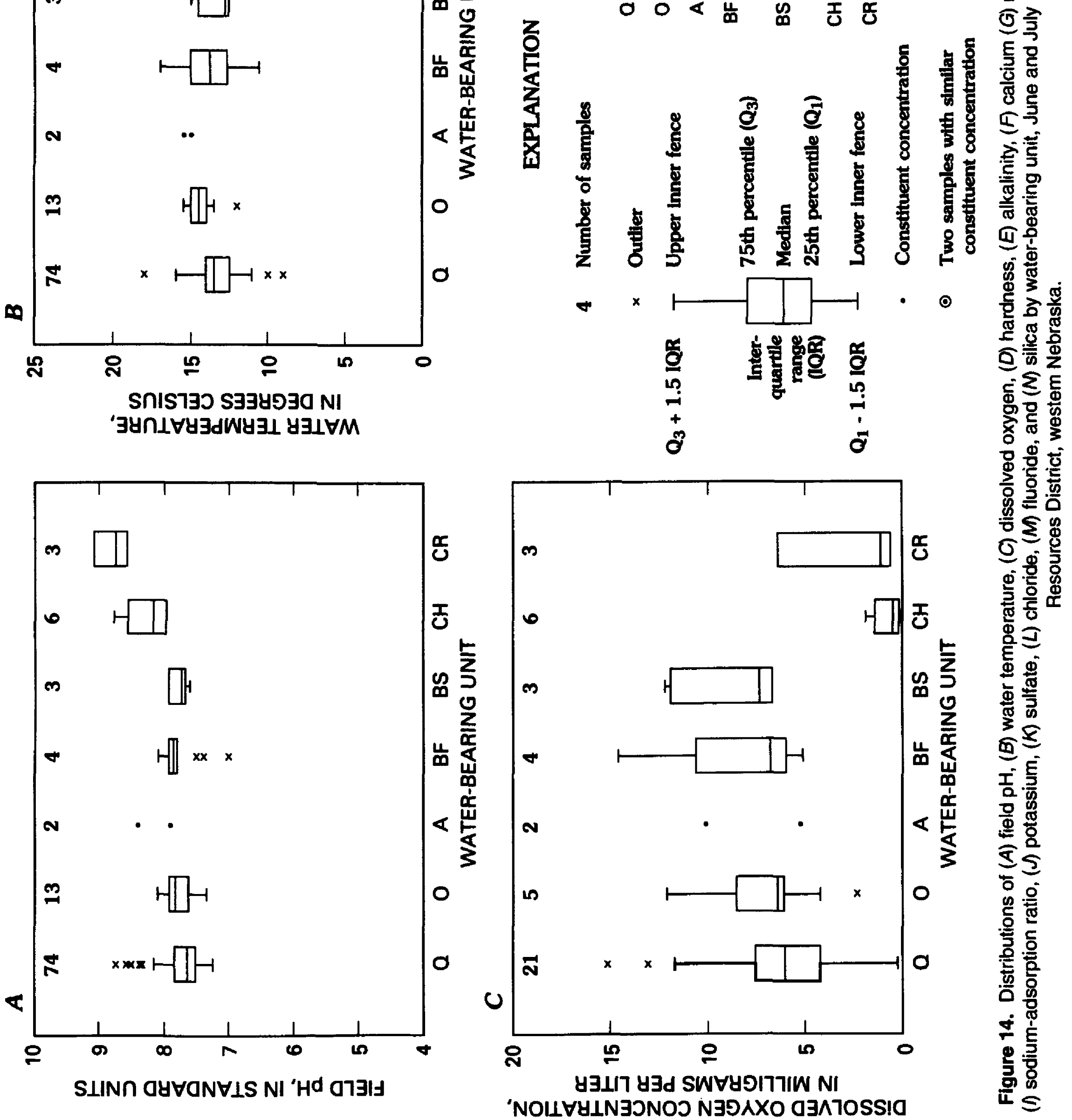

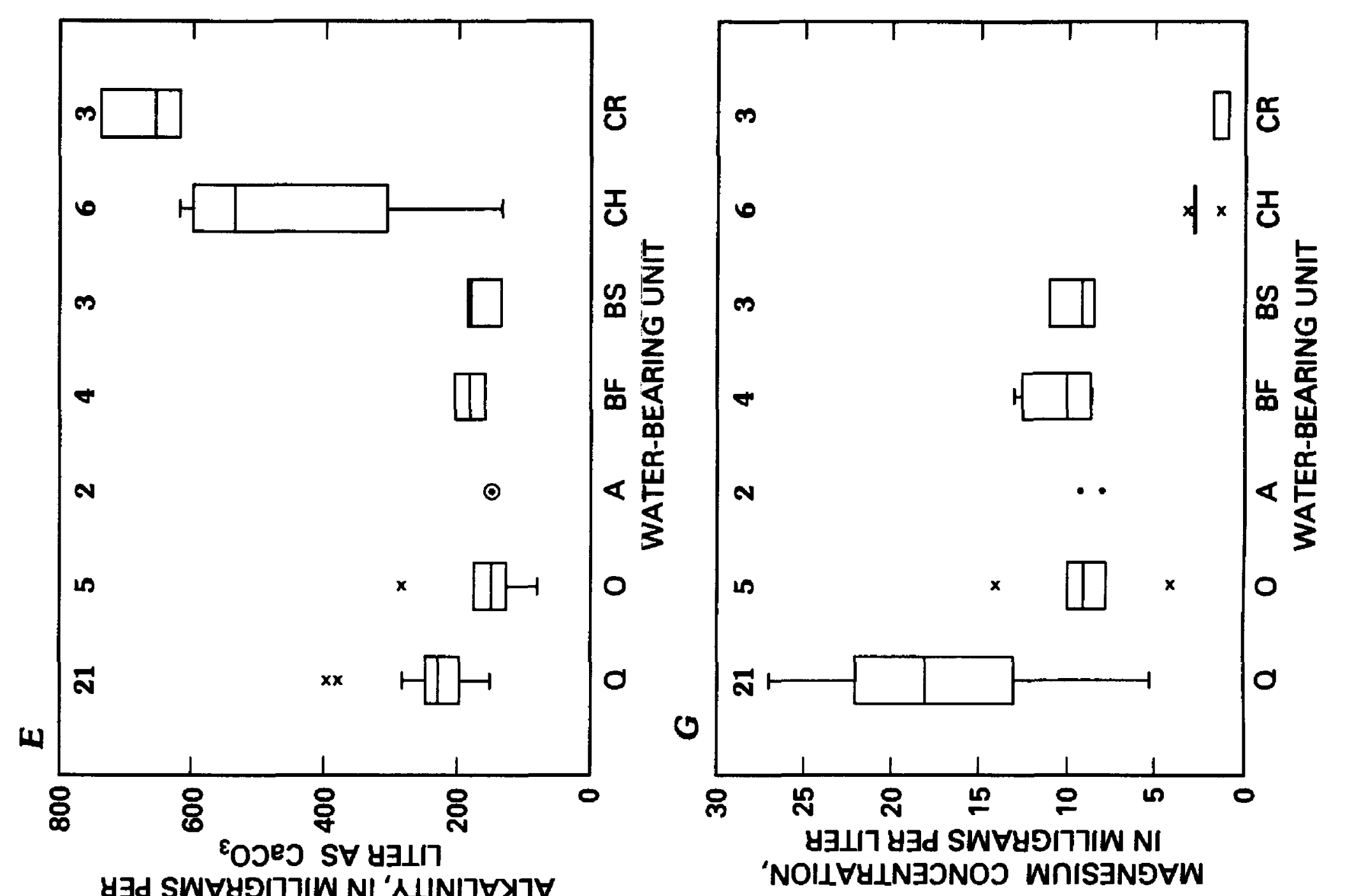

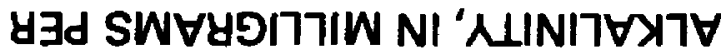

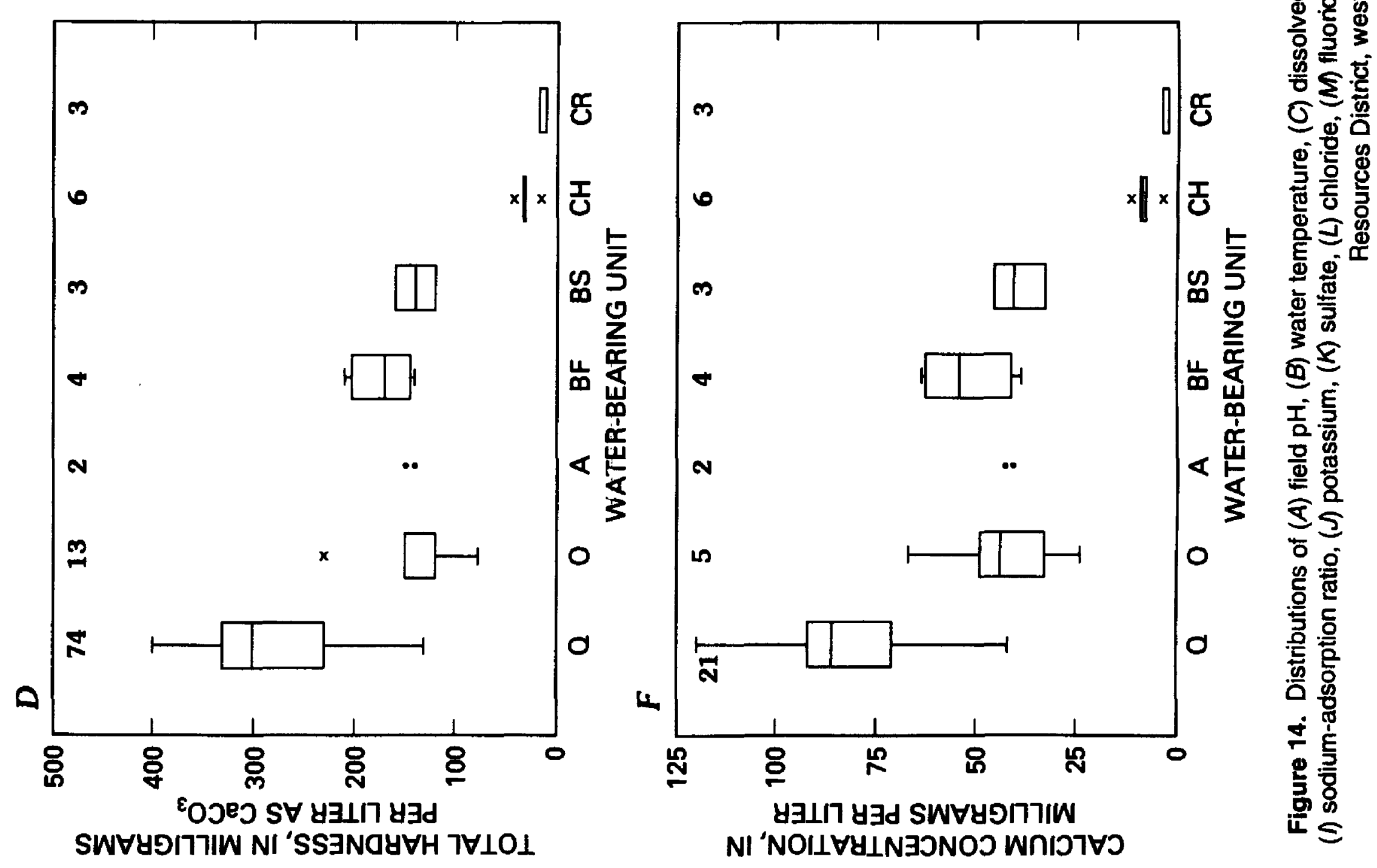



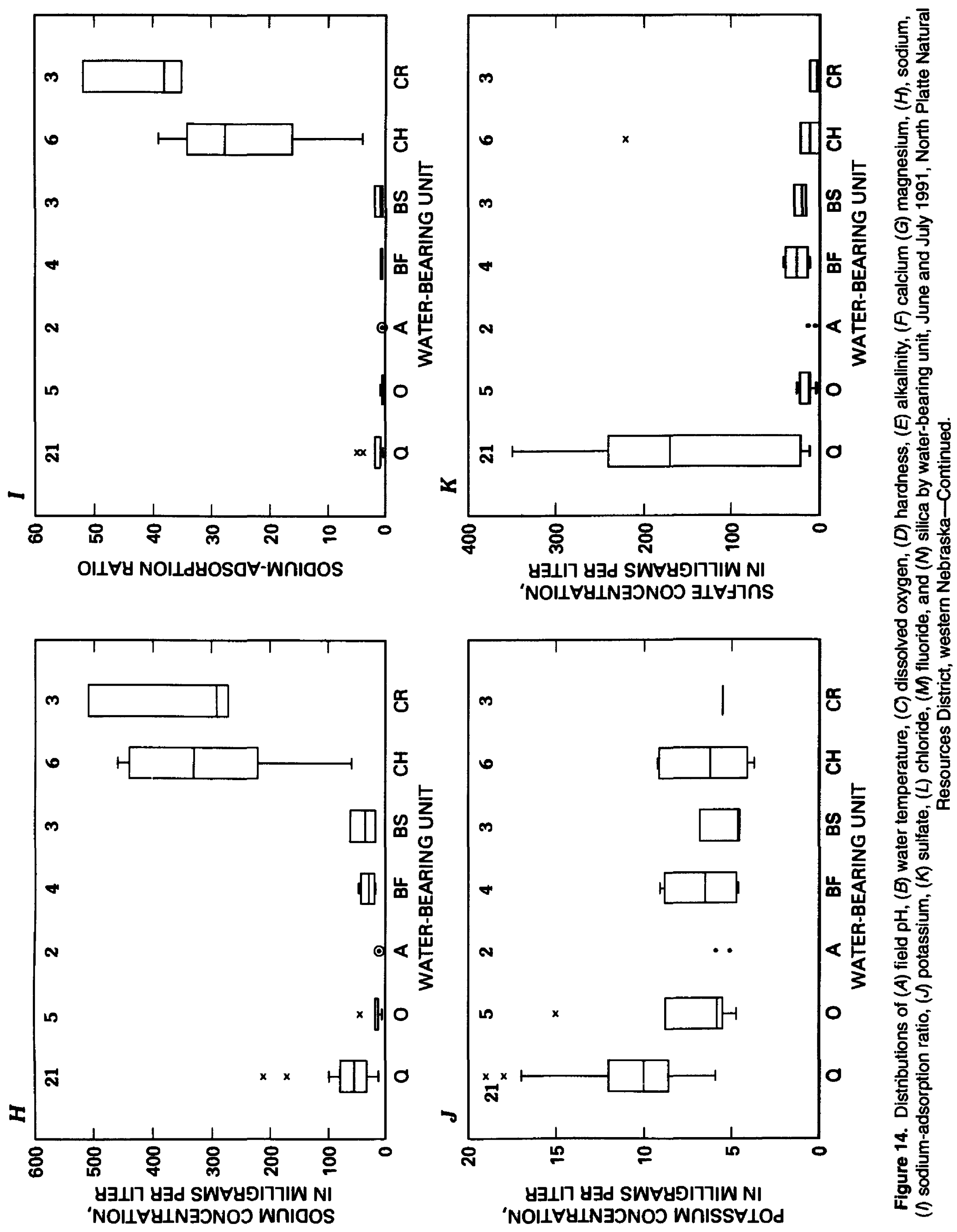


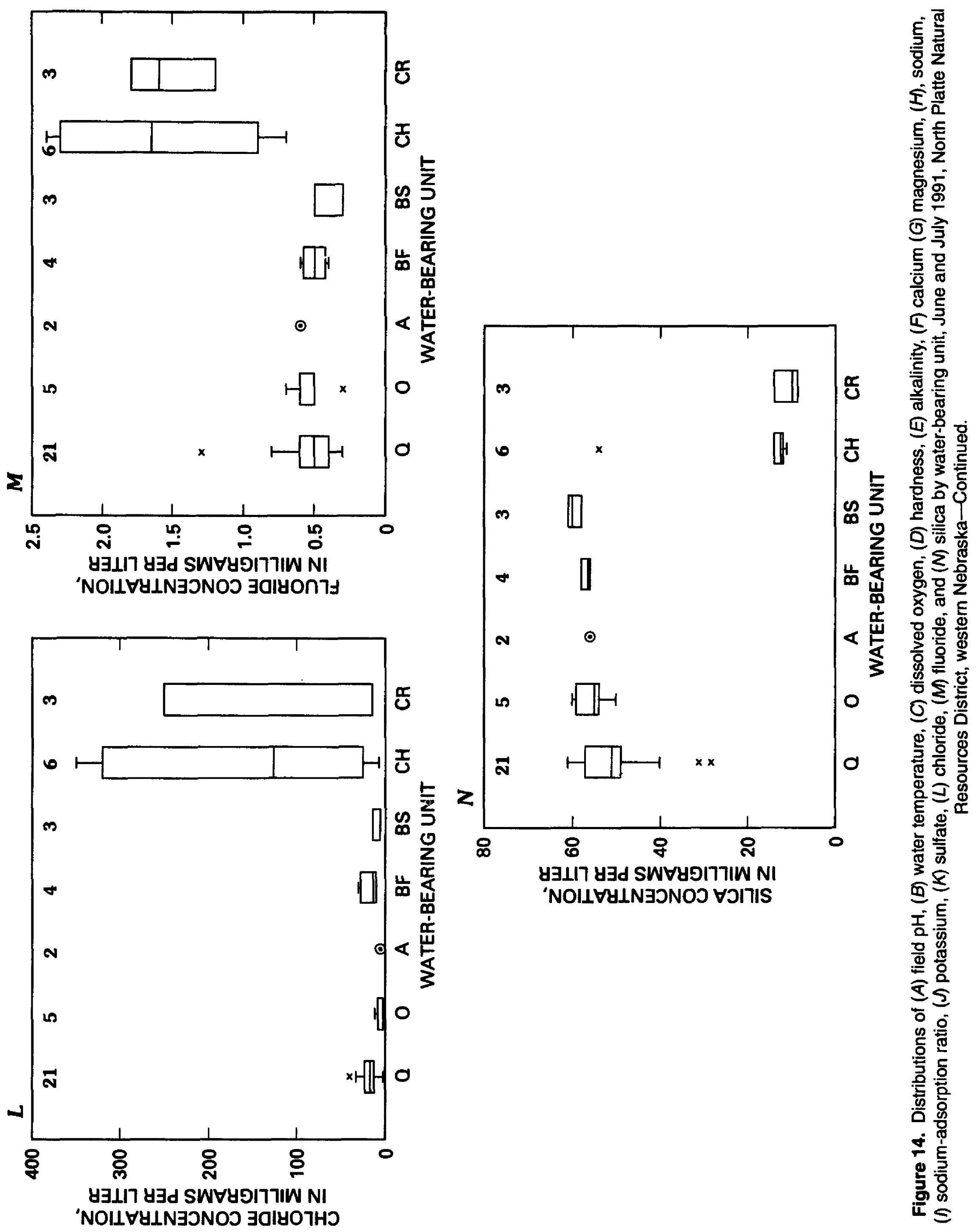


units, and undifferentiated water-bearing units of Cretaceous age contained different concentrations of sodium than water in the other water-bearing units. In general, the water from the Chadron Formation water-bearing units and undifferentiated water-bearing units of Cretaceous age had larger concentrations of sodium, a larger sodiumadsorption ratio, and larger amount of alkalinity, as illustrated in figures 13 and 14.

Results of the Wilcoxon Rank Sum test on selected groups of water-bearing units indicated that the water in the Quaternary-age water-bearing units had a different distribution of concentrations of calcium, magnesium, potassium, and sulfate as compared to the median concentrations of these constituents in the water of other water-bearing units at an alpha level of 0.001 . The statistical tests also indicated that the chemistry of water obtained from the Chadron Formation water-bearing units and undifferentiated water-bearing units of Cretaceous age did show significant differences of median concentrations among all constituents discussed in this section at an alpha level of 0.001 , except potassium, sulfate, and chloride.

\section{Summary of Water Chemistry and Water Types by Water-Bearing Units}

Because significant differences in water quality were detected among the water-bearing units, the following discussions are by group of waterbearing units. This section includes a summary of water chemistry, water types, number of constituent concentrations that exceed USEPA MCL's. A summary of the constituents discussed in this section and the number of concentrations that exceed MCL's are presented in table 8. Boxplots showing the distribution of water temperature, dissolved oxygen, $\mathrm{pH}$, hardness, alkalinity, calcium, magnesium, sodium, sodium-adsorption ratio, potassium, sulfate, chloride, fluoride, and silica are presented in figure 14.

Water types are used in this report to designate the differences in the ionic composition of the ground water of the water-bearing units under study. As water moves from the atmosphere through the sediments, it interacts with the minerals in the sediments. The chemistry of the water is changed through dissolution of minerals or through cation-exchange processes as it moves from recharge areas through the ground-water flow system to discharge areas. Thus, as ground water moves through the flow system, the calculated dissolved-solids concentrations will tend to increase (Hamilton and others, 1991). The diagrams in figure 13 reflect the predominant cation(s) and anion(s) and are used to distinguish between water types of the water-bearing units.

\section{Quaternary-Age Water-Bearing Unita}

Water from the Quaternary-age water-bearing units is a calcium bicarbonate type (fig. 13) with small chloride (median $17 \mathrm{mg} / \mathrm{L}$ ) and fluoride (median $0.5 \mathrm{mg} / \mathrm{L}$ ) concentrations and with large sulfate concentrations in some wells (median $170 \mathrm{mg} / \mathrm{L}$ ) (fig. 14). The median calcium $(86 \mathrm{mg} / \mathrm{L})$, magnesium $(18 \mathrm{mg} / \mathrm{L})$, and potassium $(10 \mathrm{mg} / \mathrm{L})$ concentrations are larger in these waterbearing sediments than in the others included in this study (fig. 14, table 9). The wells with water that have large sulfate concentrations generally are located along the Platte River and have depths of less than 130 feet. Overall, the water quality in Quaternary-age water-bearing units is more variable than that in the other water-bearing units as illustrated by the interquartile range and length of the whiskers of the boxplots shown in figure 14 and by the larger differences between minimum and maximum values listed in table 9 . The variability in these data could indicate that the water quality in the Quaternary-age water-bearing units is affected locally by recharge from irrigation canals, by the Platte River, and by possible point- and nonpoint-source contamination.

Water from Quaternary-age water-bearing units, with a median hardness of $300 \mathrm{mg} / \mathrm{L}$, is hard, in general. Hardness (as calcium carbonate$\mathrm{CaCO}_{3}$ ) exceeding $100 \mathrm{mg} / \mathrm{L}$ is objectionable for domestic use (Hem, 1985). In general, if hardness concentrations are greater than $121 \mathrm{mg} / \mathrm{L}$, the water is considered hard, whereas water with hardness less than $60 \mathrm{mg} / \mathrm{L}$ is considered soft.

The alkalinity of waters in this study is assumed to be the bicarbonate type. Sources of alkalinity are atmospheric carbon dioxide and carbon dioxide produced through decay of organic matter or lignite. Calcite tends to affect the degree of alkalinity of water by controlling the concentrations of carbonate and bicarbonate ions existing 
under equilibrium conditions (Engberg, 1984). Calcium bicarbonate generally originates from the presence of calcium in the soil and conversion of atmospheric carbon dioxide to bicarbonate (Engberg, 1984). Alkalinity also may increase due to the presence of anions derived from the solution of weak acids. Silicate ions also can contribute to alkalinity. The alkalinity of water within the Quaternary-age water-bearing units is generally less than $300 \mathrm{mg} / \mathrm{L}$, with a median of $230 \mathrm{mg} / \mathrm{L}$ (fig. 14 and table 9), which is smaller than the median alkalinity of the confined Chadron Formation and undifferentiated water-bearing units of Cretaceous age, with medians of 530 and $650 \mathrm{mg} / \mathrm{L}$, respectively (tables 14 and 15 ).

The Secondary Maximum Contaminant Level (SMCL) for sulfate is $250 \mathrm{mg} / \mathrm{L}$ (U.S.

Environmental Protection Agency, 1988d). Water from three wells had sulfate concentrations that exceeded $250 \mathrm{mg} / \mathrm{L}$ (wells Q32, Q86, and Q98 with 270,280 , and $350 \mathrm{mg} / \mathrm{L}$ as $\mathrm{SO}_{4}{ }^{2-}$, respectively). All the wells were completed in the Quaternary-age water-bearing units (table 7). The primary natural sources of sulfate ions are dissolution of evaporite minerals such as salts or gypsum, oxidation of sulfides, primarily pyrite $\left(\mathrm{FeS}_{2}\right)$, from sedimentary or weathered igneous rocks or from additions to the land surface such as fertilizerspecifically sulfate additions.

Natural sources of potassium in ground water, such as a potassium-rich feldspar and clay minerals, which are abundant in Quaternary-age water-bearing units, mainly contribute to the potassium concentrations. Also, application of potassium phosphate-commonly called potashin agricultural areas could be responsible for some of the large potassium concentrations in the water from Quaternary-age water-bearing units (fig. 14). In addition, irrigation might cause exchange of potassium with calcium and magnesium, which results in larger concentrations of calcium and magnesium in solution.

\section{Ogaliaia Group and Arikaree Group Water-Bearing Units, and Fractured-Bedrock and Sand Water-Bearing Units in the Bruie Formation}

The water of the Ogallala Group and Arikaree Group water-bearing units and fractured-bedrock and sand water-bearing units of the Brule
Formation is generally a calcium bicarbonate type (fig. 13). Water from fractured-bedrock waterbearing units of the Brule Formation shows larger median calcium concentration $(54 \mathrm{mg} / \mathrm{L})$ with larger median hardness $\left(170 \mathrm{mg} / \mathrm{L}\right.$ as $\left.\mathrm{CaCO}_{3}\right)$ and larger median sulfate concentrations $(26 \mathrm{mg} / \mathrm{L})$ than water from the sand water-bearing units of the Brule Formation (median calcium, $41 \mathrm{mg} / \mathrm{L}$; median hardness of $140 \mathrm{mg} / \mathrm{L}$ as $\mathrm{CaCO}_{3}$; and median sulfate, $20 \mathrm{mg} / \mathrm{L}$ ) and Ogallala Group water-bearing units (median calcium, $44 \mathrm{mg} / \mathrm{L}$; median hardness of $150 \mathrm{mg} / \mathrm{L}$ as $\mathrm{CaCO}_{3}$; and median sulfate, $12 \mathrm{mg} / \mathrm{L}$ ) (tables 10 through 13). No exceedances of MCL and SMCL for the major cations and anions were detected in water from Ogallala Group and Arikaree Group water-bearing units and fractured-bedrock and sand waterbearing units of the Brule Formation.

Chadron Formation Water-Bearing Units and Undifferentiated Water-Bearing Units of Cretaceous Age

The Chadron Formation water-bearing units and undifferentiated water-bearing units of Cretaceous age have water of a sodium bicarbonate type (fig. 13), with small median hardness (35 and $12 \mathrm{mg} / \mathrm{L})$ and small median calcium $(9.2$ and $3.2 \mathrm{mg} / \mathrm{L})$, magnesium $(2.7$ and $0.9 \mathrm{mg} / \mathrm{L})$, and sulfate ( 11 and $3.1 \mathrm{mg} / \mathrm{L}$ ) concentrations, respectively. The water-bearing units have large alkalinity (530 and $650 \mathrm{mg} / \mathrm{L}$ ) and sodiumadsorption ratio ( 27 and 38 ) and large median sodium (330 and $290 \mathrm{mg} / \mathrm{L}$ ) and fluoride (1.6 and $1.6 \mathrm{mg} / \mathrm{L}$ ) concentrations, respectively (tables 14 and 15). The median chloride concentration of water from the Chadron Formation water-bearing units was the largest ( $126 \mathrm{mg} / \mathrm{L})$ of all waterbearing units studied. Ranges of constituent concentrations also are noted in tables 14 and 15 .

In general, water within Chadron Formation water-bearing units and undifferentiated confined water-bearing units of Cretaceous age has a different chemistry than water from other waterbearing units discussed in this report. The differences in water chemistry such as alkalinity and sodium (tables 16 and 17) may indicate the absence of hydraulic connection between the overlying water-bearing units and the Chadron Formation water-bearing units and undifferentiated water-bearing units of Cretaceous age and may 
suggest a potential hydraulic connection between the Chadron Formation water-bearing units and undifferentiated water-bearing units of Cretaceous age. The similarities in the major element chemistry of the Chadron Formation water-bearing units and undifferentiated water-bearing units of Cretaceous age also may reflect the relative older age of the water contained in these sediments as compared to the younger water in the overlying sediments. In general, both the Chadron Formation water-bearing units and undifferentiated waterbearing units of Cretaceous age have water that is more mineralized and softer with smaller concentrations of silica than water from the other units (figure 14 and tables 16 and 17). The larger silica concentrations in water from the unconfined water-bearing units are typical of western Nebraska (Durum, 1952).

The median concentration of chloride $(126 \mathrm{mg} / \mathrm{L})$ in water from the Chadron Formation water-bearing units was less than the SMCL for chloride of $250 \mathrm{mg} / \mathrm{L}$ (U.S. Environmental Protection Agency, 1988d). However, the SMCL was exceeded in two wells within the Chadron Formation water-bearing units (domestic wells $\mathrm{CH} 104$ and CH105, with 320 and $350 \mathrm{mg} / \mathrm{L}$, respectively). In addition, well $\mathrm{CR} 78$, a domestic well completed in the undifferentiated waterbearing units of Cretaceous age, had a chloride concentration equal to the SMCL (table 7). The large chloride and sodium concentrations in the water from the Chadron Formation water-bearing units may indicate a good hydraulic connection with the underlying marine undifferentiated waterbearing units of Cretaceous age or a similar chemical evolution of ground water in both units.

Even though the Chadron Formation waterbearing units and undifferentiated water-bearing units of Cretaceous age had the largest fluoride concentrations (tables 14 and 15), only the Chadron Formation water-bearing units contained water that exceeds the SMCL of $2.0 \mathrm{mg} / \mathrm{L}$. [wells CH106 (2.4 mg/L) and CH107 (2.3 mg/L), an irrigation and domestic well, respectively]. No water samples exceeded the MCL of $4.0 \mathrm{mg} / \mathrm{L}$. Fluoride is present in sedimentary rock, mainly as fluorapatite $\left(\mathrm{Ca}_{5}\left(\mathrm{PO}_{4}\right)_{3} \mathrm{~F}\right)$ and fluorite $\left(\mathrm{CaF}_{2}\right)$.

Only water from the Chadron Formation water-bearing units and undifferentiated waterbearing units of Cretaceous age had a median hardness less than $100 \mathrm{mg} / \mathrm{L}$ (35 and $12 \mathrm{mg} / \mathrm{L}$ as $\mathrm{CaCO}_{3}$, respectively). The small calcium and magnesium and the large sodium concentrations in the water from these units could indicate exchange for sodium in clay minerals.

Overall, the major ion water chemistry in the Chadron Formation water-bearing units and undifferentiated water-bearing units of Cretaceous age is relatively uniform, except for sodium and chloride (fig. 14). The greater variability in constituent concentrations of sodium and chloride, and consequently the alkalinity and the sodiumadsorption ratio, may be related to local variations in the mineralogy of the water-bearing sediment. The low concentrations and small variability in sulfate and dissolved-nitrate concentrationsconstituents that may reflect point- or nonpointsource contamination-could indicate that the ground water within these units generally has not been affected by contamination or could be related to the reducing conditions thought to exist within these water-bearing units.

The water from these confined water-bearing units, which has large values of specific conductance and sodium-adsorption ratio, is not suitable for irrigation because of its potential adverse effects on crops. The water from these confined water-bearing units also could affect the unconfined ground water in overlying water-bearing units by vertical seepage of the irrigation water through the unsaturated, unconsolidated sediments. As sodium-adsorption ratio increases, the suitability of the water for irrigation decreases.

\section{pH and Dissolved Oxygen}

$\mathrm{pH}$ in water from the seven water-bearing units varied from 7.2 to 9.1 , with a median of 7.8 (tables 6 and 8). $\mathrm{pH}$ is an indication of the acidity of the water. Ground water with a pH from 6.5 to 7.8 is considered neutral (Hem, 1985). Water with a pH greater than 7.8 is considered alkaline. Water with a $\mathrm{pH}$ less than 6.5 is considered acidic.

The largest $\mathrm{pH}$ values were detected in water from the confined Chadron Formation waterbearing units and undifferentiated water-bearing units of Cretaceous age (median of 8.2 and 8.8, respectively). Two water samples obtained from the Chadron Formation water-bearing units, three water samples from undifferentiated water-bearing 
units of Cretaceous age, and two water samples from Quaternary-age water-bearing units exceeded the SMCL for $\mathrm{pH}$ of 8.5 (domestic wells CR78, CH103, CH107, CR108, and CR109 and irrigation wells Q95 and Q114 with a pH of 8.8, 8.6, 8.8, 8.6, 9.1, 8.6, and 8.7, respectively). All the unconfined water-bearing units had a similar median $\mathrm{pH}$ of about 7.8. Several outliers can be seen in the boxplot of $\mathrm{pH}$ for water from Quaternary-age water-bearing units shown in figure 14.

Although the largest $\mathrm{pH}$ value was measured in water from the confined Chadron Formation waterbearing units and undifferentiated water-bearing units of Cretaceous age, the smallest dissolvedoxygen concentrations were detected in this confined water. Dissolved-oxygen concentrations in all of the ground-water samples collected for this study varied from 0.1 to $15.1 \mathrm{mg} / \mathrm{L}$, with a median of $6.3 \mathrm{mg} / \mathrm{L}$ (table 8 ). The median dissolvedoxygen concentrations in water from the Chadron Formation water-bearing units and undifferentiated water-bearing units of Cretaceous age were 0.5 and $1.1 \mathrm{mg} / \mathrm{L}$, respectively (tables 14 and 15 ). In contrast, the median dissolved-oxygen concentrations in water from the unconfined waterbearing units varied from $6.0 \mathrm{mg} / \mathrm{L}$ in the water from Quaternary-age water-bearing units to $7.3 \mathrm{mg} / \mathrm{L}$ in water from sand water-bearing units in the Brule Formation (tables 9 and 10, respectively).

\section{Specific Conductance and Calculated Dissolved Solids}

Specific conductance varied from 188 to $2,130 \mu \mathrm{S} / \mathrm{cm}$ (microsiemens per centimeter at $25^{\circ} \mathrm{C}$ ) (table 8). Specific conductance is positively correlated with calculated dissolved-solids concentrations $(r=0.75)$. Specific conductance and calculated dissolved-solids concentrations are positively correlated with sodium $(r=0.92$ and $r=0.68$, respectively), chloride $(r=0.87$ and $r=0.64$, respectively), and boron $(r=0.92$ and $r=0.68$, respectively). The boxplots shown in figure 15 illustrate that water in confined Chadron Formation water-bearing units and undifferentiated water-bearing units of Cretaceous age and in unconfined Quaternary-age water-bearing units has larger median specific conductance and calculated dissolved-solids concentrations than the other water-bearing units. The distribution of concentrations for these characteristics is the same in all water-bearing units on the basis of the KruskalWallis test (table 16).

Calculated dissolved solids in all water-bearing units varied from 158 to $1,240 \mathrm{mg} / \mathrm{L}$, with a median of $418 \mathrm{mg} / \mathrm{L}$ (table 8). Calculated dissolved-solids concentration is a calculation of all constituents dissolved in water (sum of constituents) and generally is correlated positively with specific conductance as illustrated in figure $15 C$. Linear regression analysis indicates that the slope of calculated dissolved solids and specific conductance is 0.59 (fig. 15). Increased calculated dissolved solids can arise from mineral dissolution, extraneous additions of solids, or the presence of saline water.

Twenty wells completed in the Quaternary-age and Chadron Formation water-bearing units and undifferentiated water-bearing units of Cretaceous age exceeded the SMCL of 500 milligrams per liter ( $\mathrm{mg} / \mathrm{L}$ ) for calculated dissolved solids. Water with calculated dissolved-solids concentrations that exceed $1,000 \mathrm{mg} / \mathrm{L}$ can adversely affect crops. Large concentrations of calculated dissolved solids also may affect poultry and livestock on a temporary basis when they are not accustomed to the consumption of this water (Hem, 1985). Water in three wells (wells Q98, CH104, and CR78 completed in Quaternary-age and Chadron Formation water-bearing units and undifferentiated water-bearing units of Cretaceous age with 1,020, 1,170 , and $1,240 \mathrm{mg} / \mathrm{L}$, respectively) had calculated dissolved-solids concentrations that exceeded $1,000 \mathrm{mg} / \mathrm{L}$.

\section{Major Metals and Selected Trace Elements}

Major metals and trace elements in ground water can be attributed to both natural and human sources. Potential human sources include acid rain, fertilizer additions, such as copper and zinc sulfates, and industry-related point sources.

Many water samples had concentrations of trace elements less than the detection limit (table 7). Statistical nonparametric analysis of major metals and selected trace elements is difficult because of trace-element concentrations that are less than the detection level. Although the preferred method used to estimate the distribution 


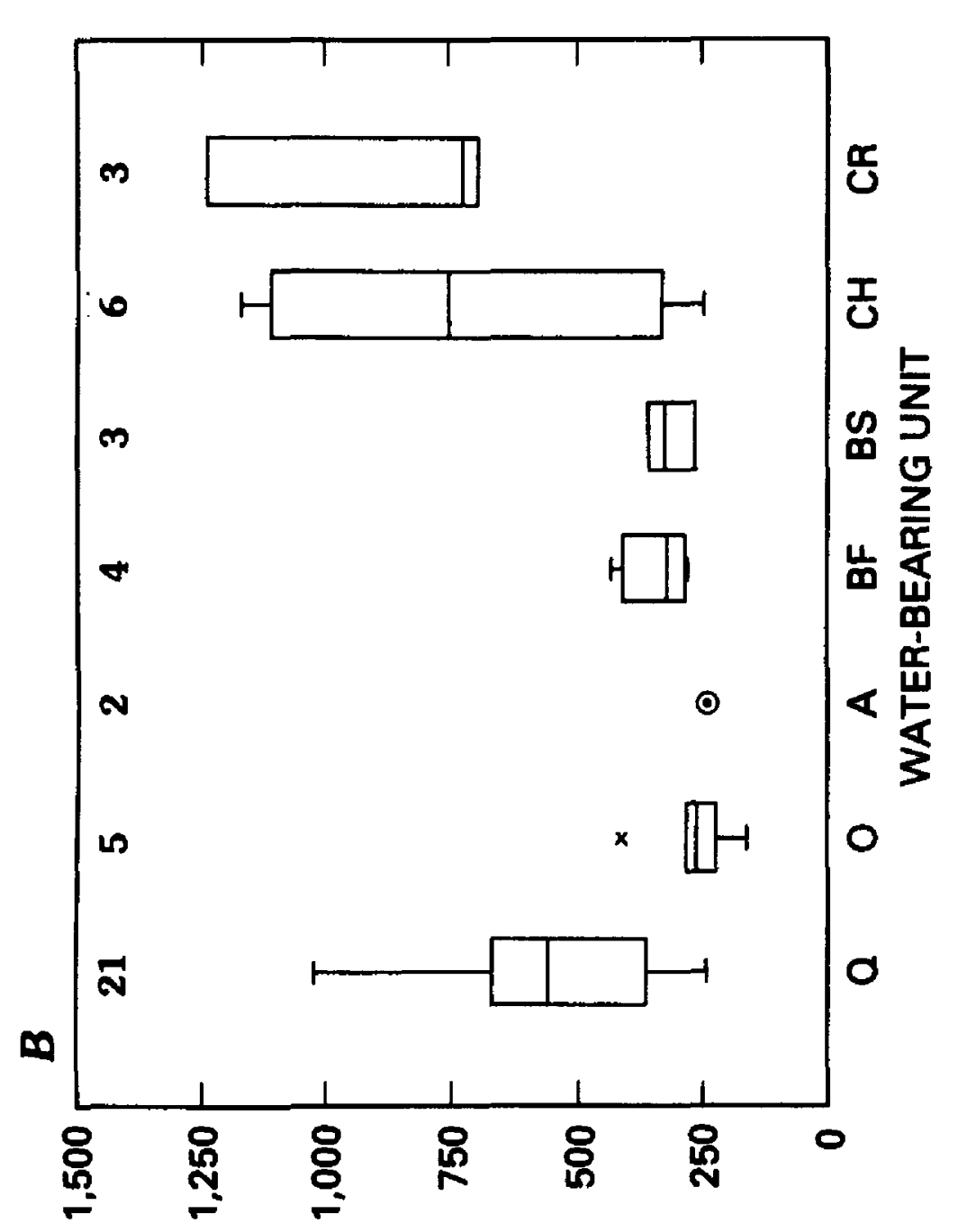

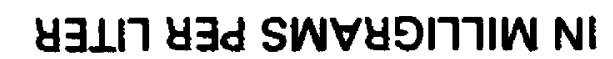

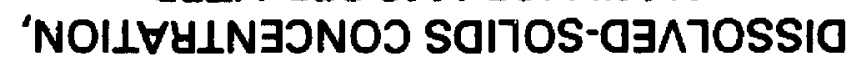

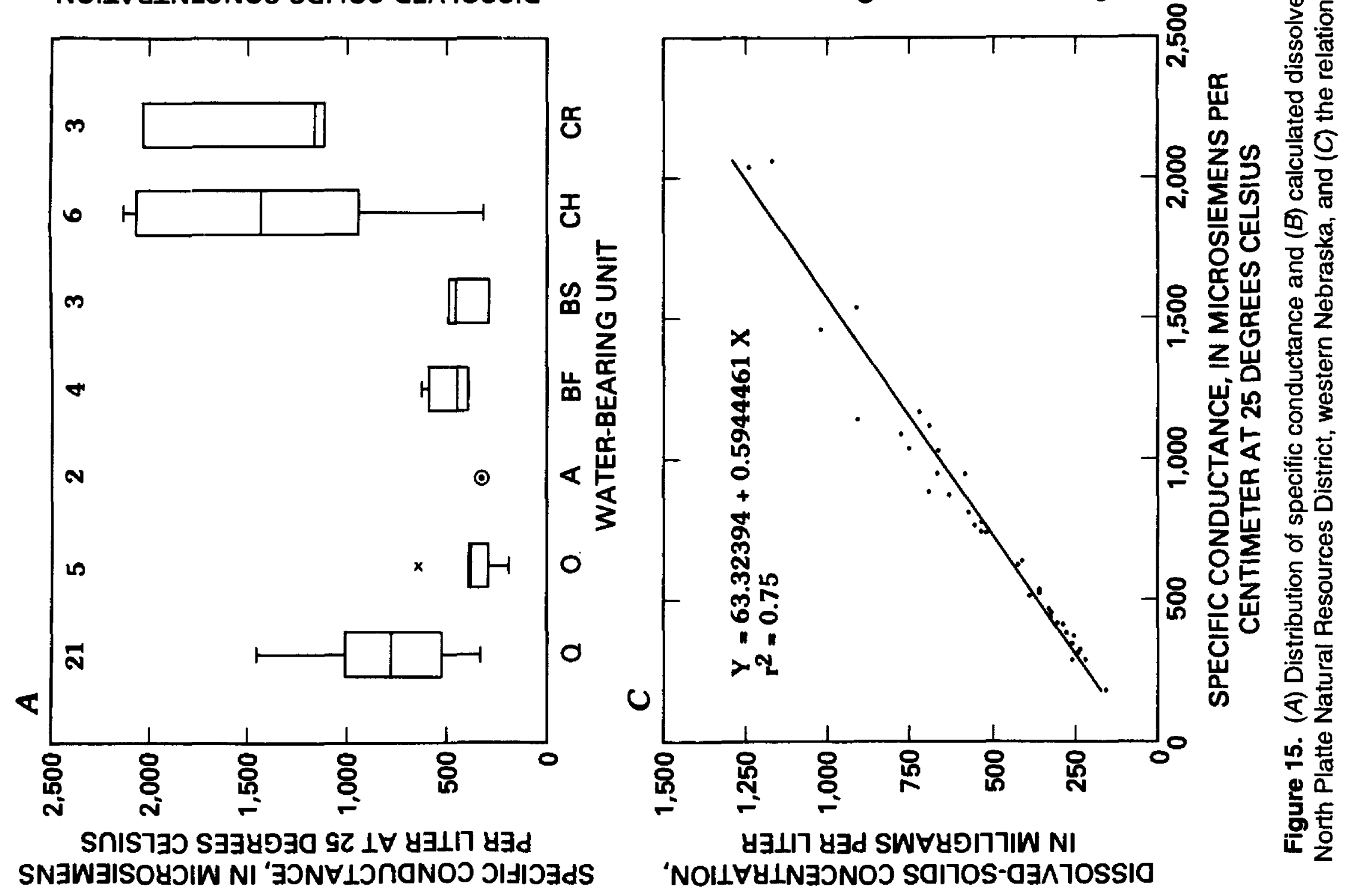


is the log-probability test method (Helsel and Gilliom, 1985), values less than the detection level were considered to be zero in this study. Consequently, parametric statistical hypothesis testing, distribution estimation, and correlation were biased. Boxplots showing the distribution of arsenic, barium, boron, iron, lithium, manganese, selenium, strontium, vanadium, and zinc are presented in figure 16.

Nonparametric analysis of the water-quality data with the Kruskal-Wallis test (alpha $=0.001$ ) indicated that the distribution of concentrations of boron $(p=0.00016)$, selenium ( $p=0.00056)$, and strontium $(\mathrm{p}=0.00062)$ was different in at least one group (table 16).

Tukey's test indicated that water from several water-bearing units had different concentrations of boron, selenium, and strontium (table 17). In addition, subsequent grouping of the water-bearing units and statistical analysis using the Wilcoxon Rank Sum test indicated that the Chadron Formation water-bearing units and undifferentiaced confined water-bearing units of Cretaceous age have different median concentrations of boron $(\mathrm{p}=0.00005)$, iron $(\mathrm{p}=0.00026)$, selenium $(p=0.00003)$, strontium $(p=0.00010)$, and vanadium ( $p=0.00002)$. Grouping of the data for water collected from Quaternary-age water-bearing units compared against the data for water collected from other water-bearing units indicates that water in the Quaternary-age water-bearing units has different median lithium $(\mathrm{p}=0.00031)$ and strontium ( $p=0.00011)$ concentrations.

In the following sections selected major metals are discussed. The selection was based on the number of detections or exceedances of MCL's or SMCL's.

\section{Iron}

Iron concentrations in water from all waterbearing units varied from less than 3 to $73 \mu \mathrm{g} / \mathrm{L}$, with a median of $5 \mu \mathrm{g} / \mathrm{L}$ (table 8 ). None of the water samples exceeded the SMCL of $300 \mu \mathrm{g} / \mathrm{L}$ for iron (table 8). The largest iron concentrations were found in water from the undifferentiated water-bearing units of Cretaceous age (maximum of $73 \mu \mathrm{g} / \mathrm{L}$ ) followed by water in the Chadron Formation water-bearing units (maximum of $39 \mu \mathrm{g} / \mathrm{L}$ ). The smallest iron concentrations were in water from the Arikaree Group water- bearing units (maximum of less than $3 \mu \mathrm{g} / \mathrm{L}$ ). Water in the Chadron Formation and undiffer- entiated water-bearing units of Cretaceous age had small dissolved-oxygen concentrations, which generally indicate reducing conditions. Usually, increased concentrations of iron are due to the presence of iron-enriched sediment in a reducing environment with small pH (Freeze and Cherry, 1979). The confined Chadron and undifferentiated Cretaceous water-bearing units apparently meet certain conditions of a reducing environment but show relatively large $\mathrm{pH}$ values. Additional information on the geochemistry of these water-bearing units is needed to provide more meaningful interpretation of the results.

\section{Manganese}

Manganese data are summarized in tables 8 through 15 and figure 16. Manganese concentrations varied from less than 1 to $130 \mu \mathrm{g} / \mathrm{L}$, with a median of less than $1 \mu \mathrm{g} / \mathrm{L}$. Relatively large concentrations of manganese (outliers) were detected in water samples from the Quaternary-age water-bearing units (wells Q7, Q32, and Q98) (fig. 16). Two water samples exceed the SMCL of $50 \mu \mathrm{g} / \mathrm{L}$ for manganese (wells Q7 and Q32 with manganese concentrations of 130 and $61 \mu \mathrm{g} / \mathrm{L}$ as $\mathrm{Mn}^{2+}$, respectively). Water from well Q98 had a manganese concentration of $34 \mu \mathrm{g} / \mathrm{L}$. Large manganese concentrations may cause a brown discoloration of the water, may deposit black manganese oxide stains on the well casing, and may affect the taste. Large manganese concentrations were not detected in the Chadron Formation water-bearing units and the undifferentiated water-bearing units of Cretaceous age.

\section{Selected Trace Elements}

Arsenic, barium, cadmium, and chromium are elements occurring in the upper lithosphere (Hem, 1985). Lead is the most abundant heavy element in the lithosphere. Selenium is found in sedimentary as well as igneous rocks and reacts in a fashion similar to sulfur. Distributions of concentrations of these trace elements are presented in figure 16. The data are listed in table 7 and a summary of the data is presented in tables 8 through 15 . 

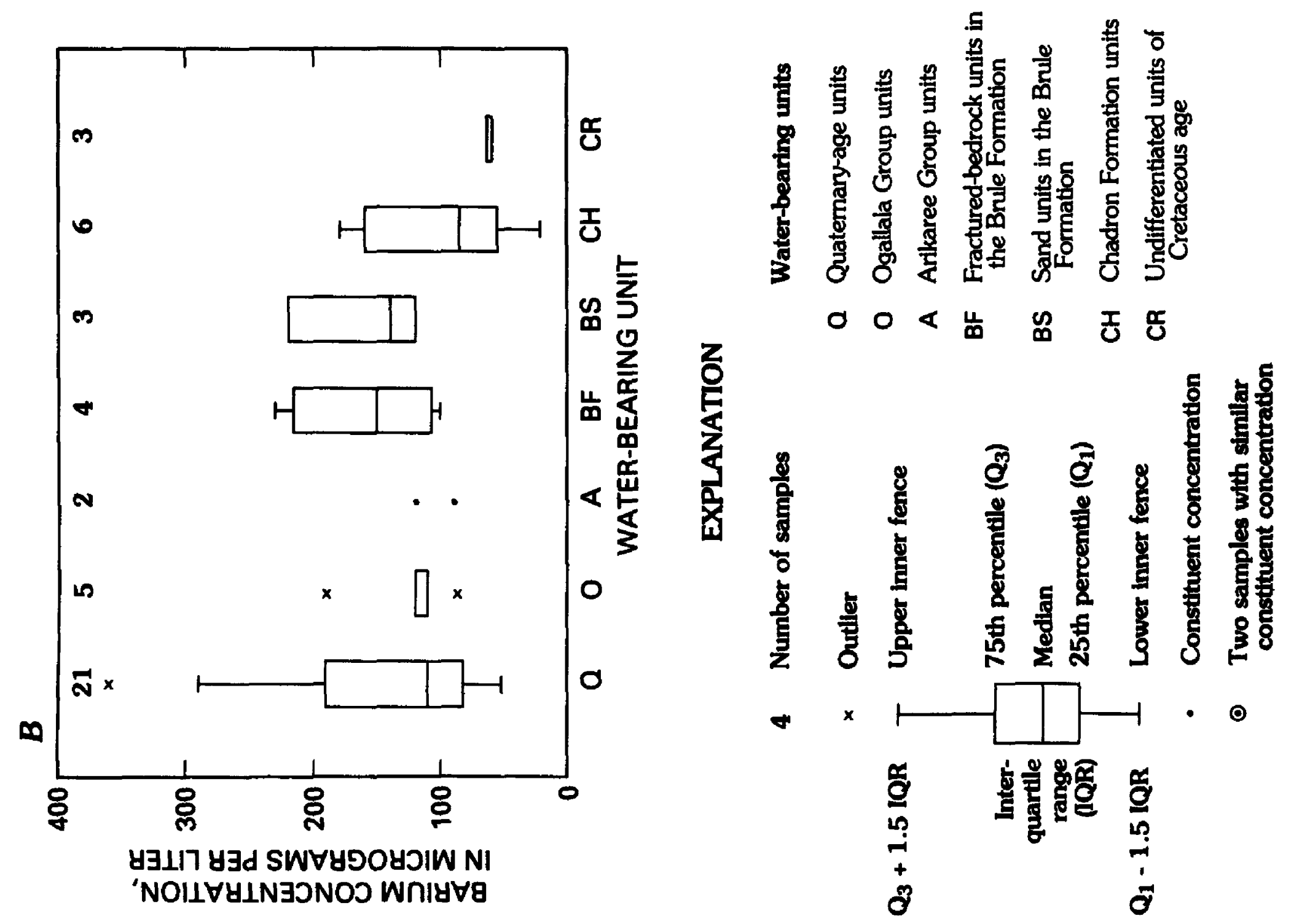

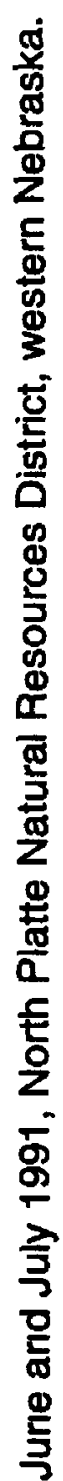

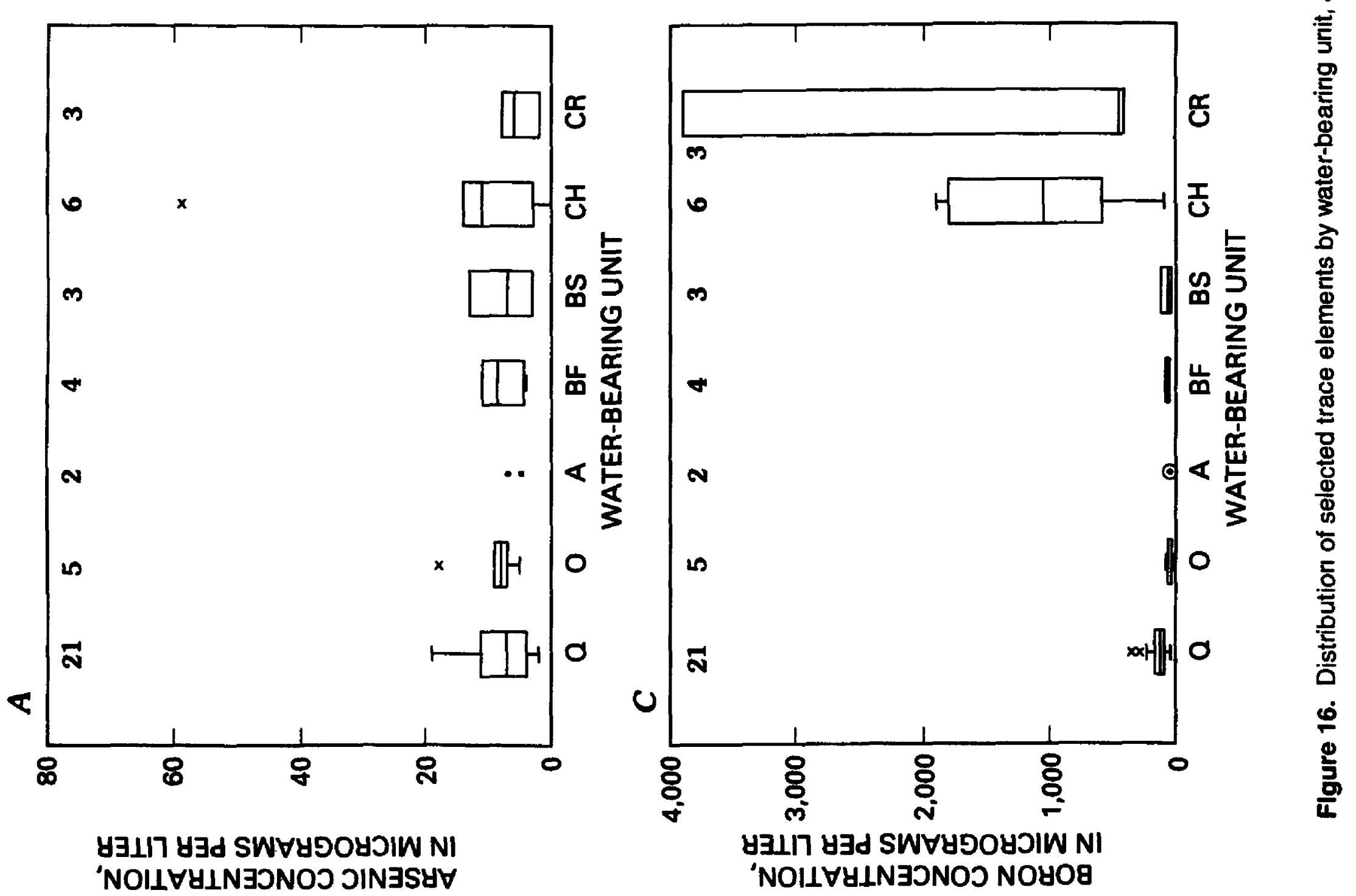



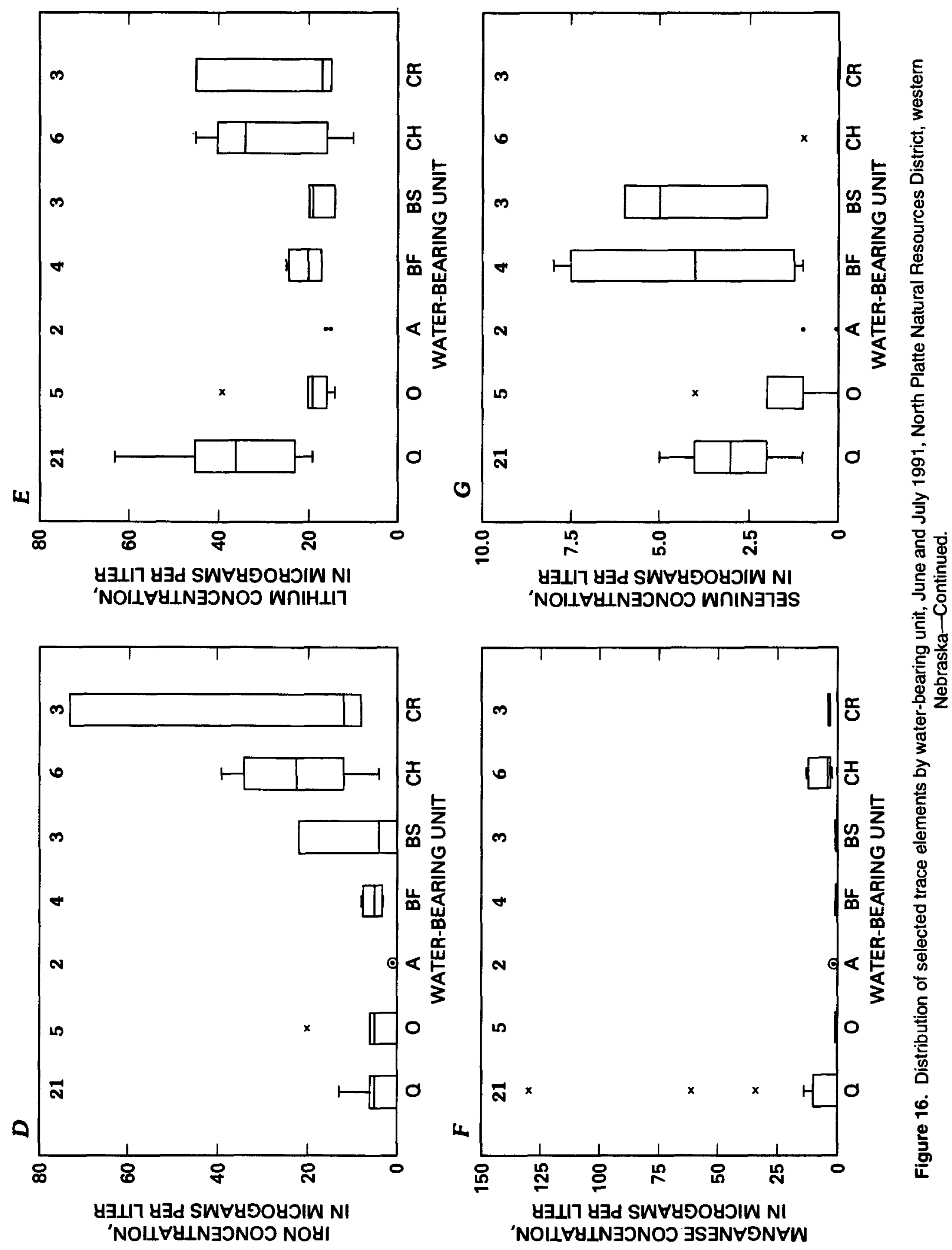


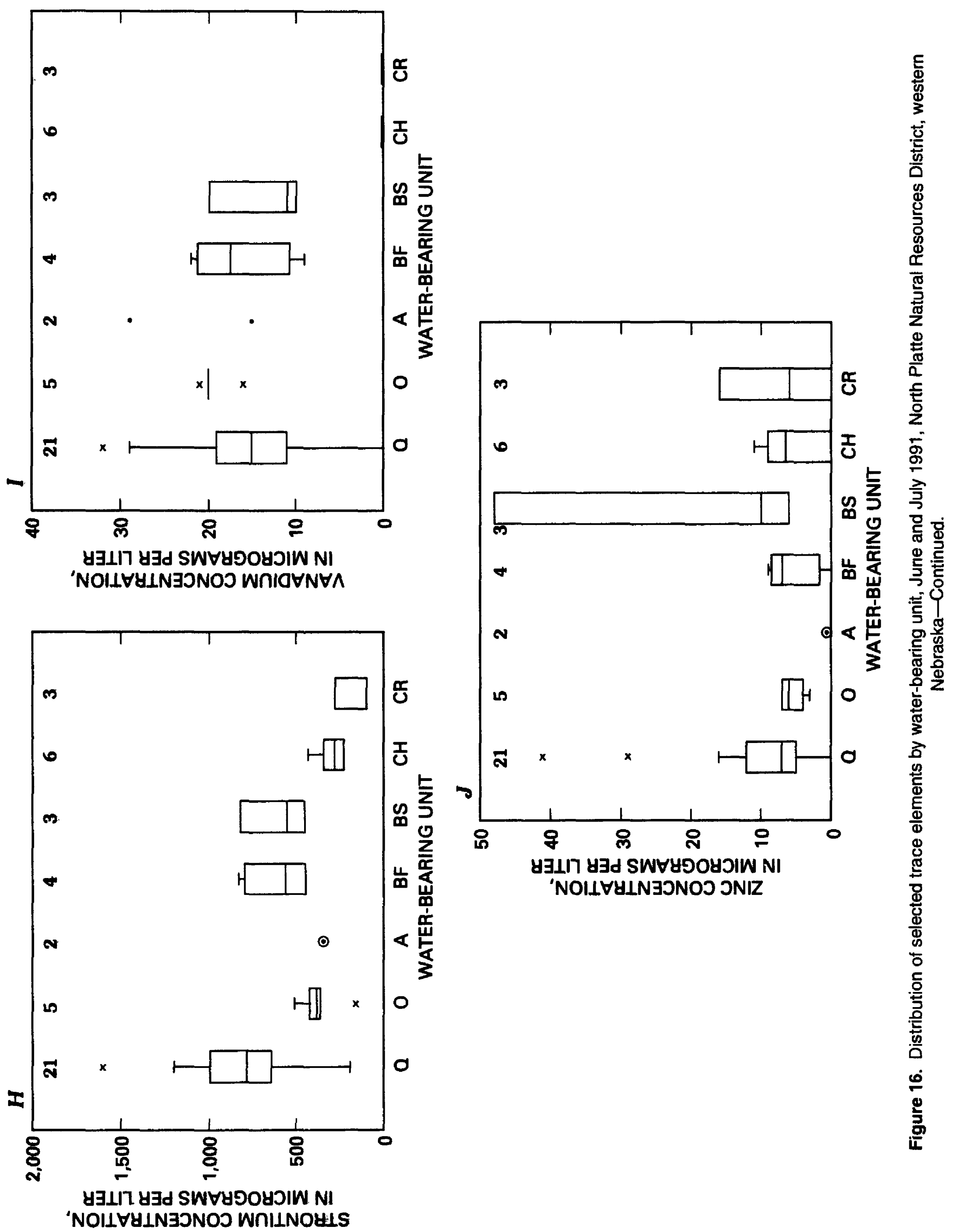


The MCL for arsenic of $50 \mu \mathrm{g} / \mathrm{L}$ was exceeded in one water sample. The large arsenic concentration $(59 \mu \mathrm{g} / \mathrm{L})$ was detected in water from well CH59. This well is 475 feet deep and screened in the Chadron Formation water-bearing units. The large arsenic concentration may be associated with an arsenic-rich horizon within these water-bearing units rather than being introduced by human sources. Water from well $\mathrm{CH} 59$ also had a large concentration of sulfate $(220 \mathrm{mg} / \mathrm{L})$, which may indicate a horizon rich in arsenosulfides within the Chadron Formation water-bearing units.

Alternatively, the large arsenic concentration may originate through flow along faults and fractures in the geologic strata.

The proposed MCL for beryllium $(1.0 \mu \mathrm{g} / \mathrm{L})$ was exceeded in water obtained from two wells (wells $\mathrm{CH} 104$ and $\mathrm{CH} 105$ both with $2.0 \mu \mathrm{g} / \mathrm{L}$ ). They are completed in the Chadron Formation water-bearing units and have depths of 555 and 430 feet, respectively. Again, the larger beryllium concentrations may be associated with a berylliumrich horizon in the Chadron Formation waterbearing units or deeper ground-water flow paths rather than having been introduced by human sources.

\section{Radionuclides}

Radionuclides are chemical elements that undergo a nuclear decay process through changes within their nucleus. These changes produce alpha and beta types of ionizing radiation. Variations in distributions of radionuclides in ground water are related not only to the natural presence of radionuclides in sediment but also are affected by human factors. Human factors include coal and nuclear-power production, mining, oil and gas production, chemical fertilizer additions (especially phosphates), and transport and disposal of radioactive materials. Fertilizer can be enriched with uranium and potassium salt (Meriwether and others, 1988). Radionuclide content in water is determined by many factors including the radionuclide concentration and distribution in the source rock, its chemical form, water chemistry such as $\mathrm{pH}$, oxidation-reduction potential, and presence of complexing agents, microbial activity, half-life of the nuclide (which determines the length of time a nuclide can accumulate in water), and the presence of sorptive materials (Hem, 1985).

Concentration of radionuclides generally is expressed in picocuries per liter ( $\mathrm{pCi} / \mathrm{L}$ ). One curie (Ci) is defined as $3.7 \times 10^{10}$ disintegrations per second. Results of radioactive measurements in water may be at or near zero.

This study reports gross alpha $(\alpha)$ activity (that is, alpha activity from all sources) reported as if it were thorium-230 $\left({ }^{230} \mathrm{Th}\right)$, gross beta $(\beta)$ activity (that is, beta activity from all sources) reported as if it were strontium-90 $\left({ }^{90} \mathrm{Sr}\right)$, radon-222 $\left({ }^{222} \mathrm{Rn}\right)$ activity, radium-226 $\left({ }^{226} \mathrm{Ra}\right)$ activity, total uranium concentration, and the ratio of uranium-238 $\left({ }^{238} \mathrm{U}\right)$ to uranium-234 $\left({ }^{234} \mathrm{U}\right)$ activities. The analytical results and uncertainties are presented in table 7 . Summary statistics of the radionuclide data are presented in tables 8 through 15 and are illustrated in figure 17 . The radioactive decay series for uraniuni-238 is illustrated in figure 18 (Orr and others, 1991), which shows the parent and daughter relations of radon-222 and radium-226 to uranium-238.

The Kruskal-Wallis test indicates that the distribution of gross beta and radon activities was not the same in all water-bearing units $(p=0.00001)$. Tukey's test indicated that the water from Quaternary-age water-bearing units and fractured-bedrock water-bearing units in the Brule Formation had different gross beta activities than water from the other water-bearing units. Tukey's test also indicated that the water from the fractured-bedrock and sand water-bearing units in the Brule Formation and Chadron Formation water-bearing units and undifferentiated waterbearing units of Cretaceous age had different radon-222 activities than water from the other water-bearing units at a alpha level of 0.05 (table 17). Similarly, the Wilcoxon Rank Sum test indicated that water from the fractured-bedrock and sand water-bearing units of the Brule Formation had significantly different distributions of concentrations of radon-222 $(p=0.00031)$ than water from the other water-bearing units at a statistical alpha level of 0.001 (table 16).

\section{Gross Alpha and Beta Activities}

Gross-alpha activity originates from the decay chains of uranium-238, thorium-232, and 

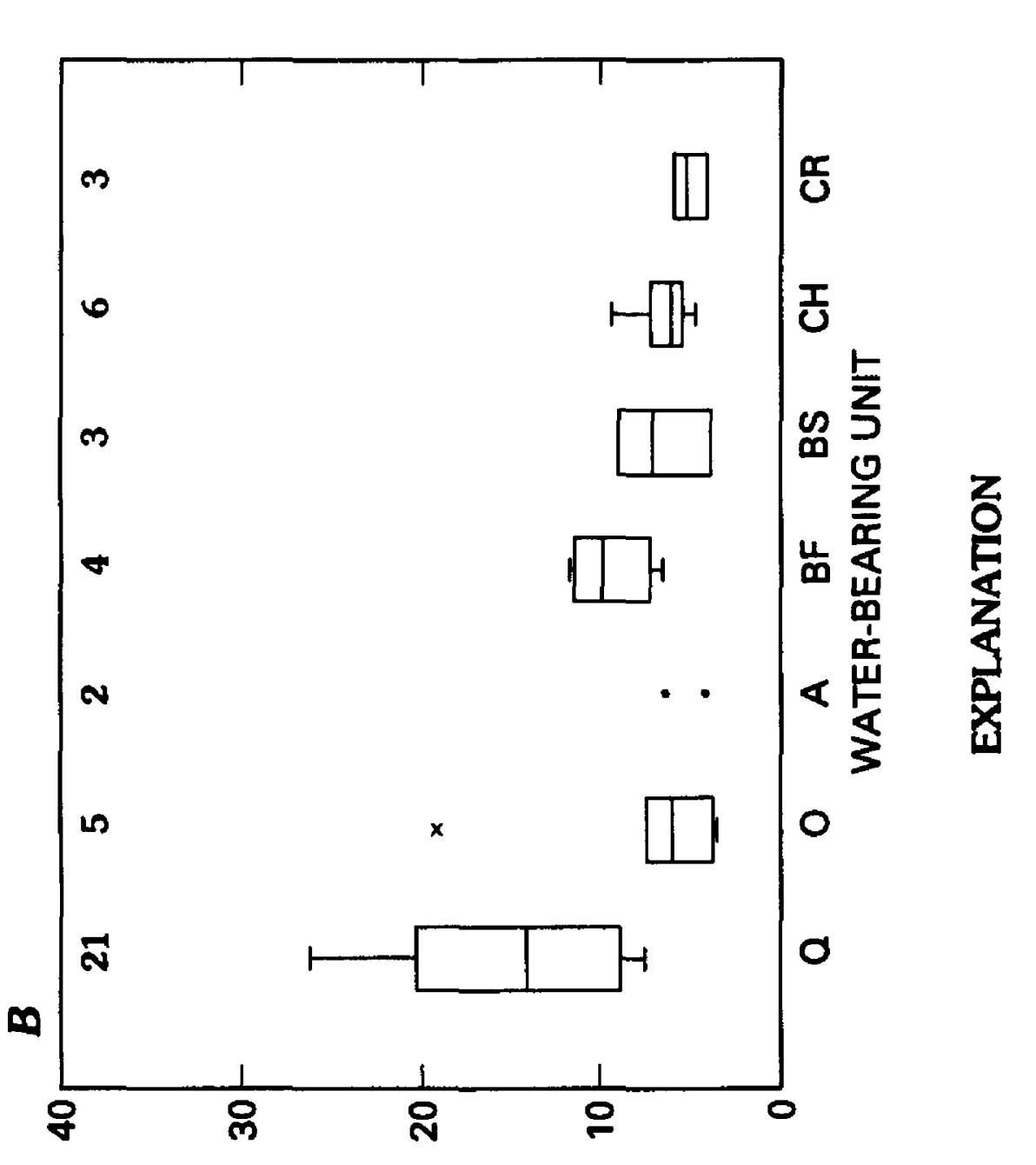

y

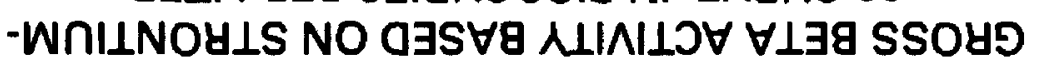

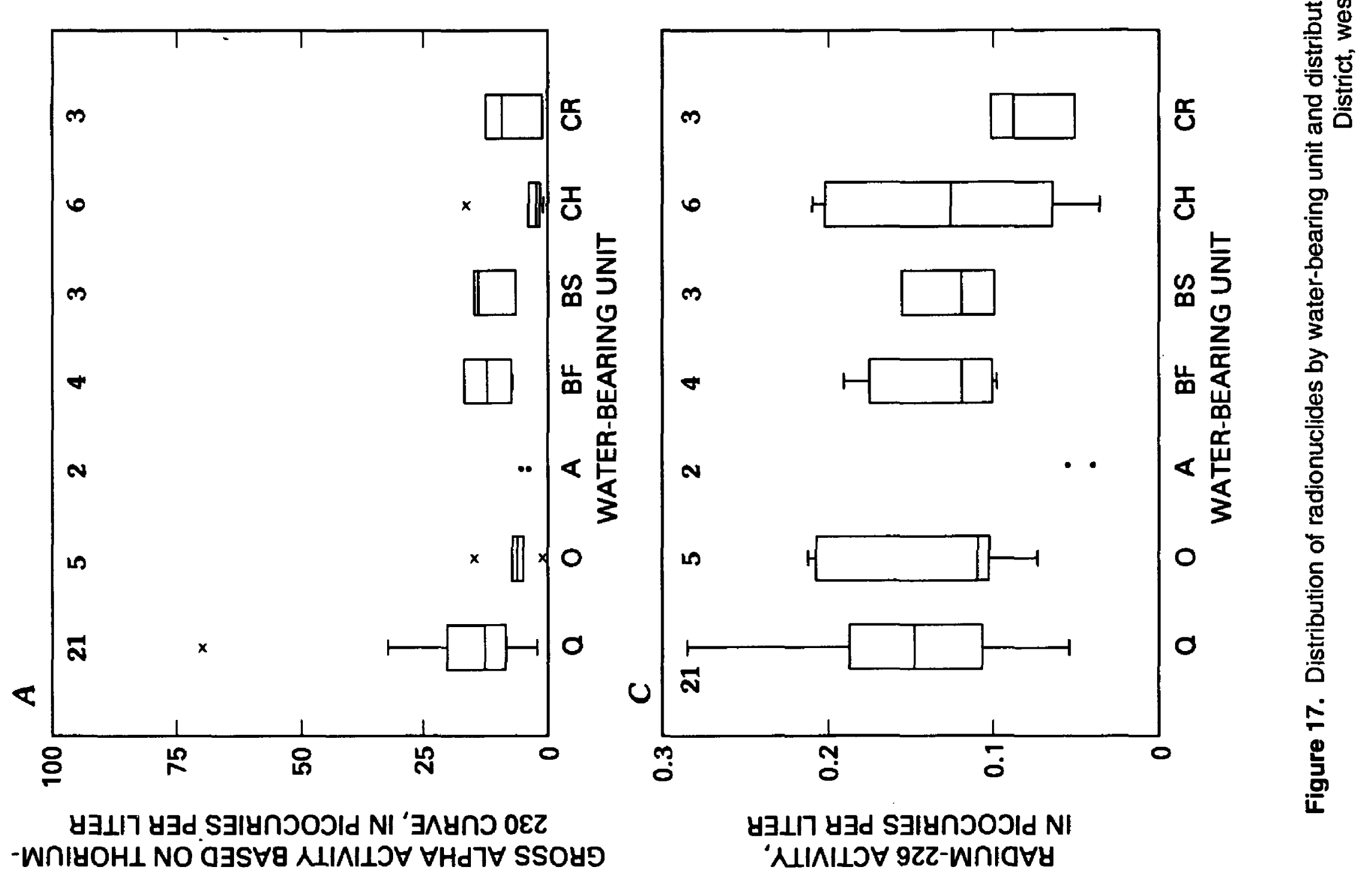



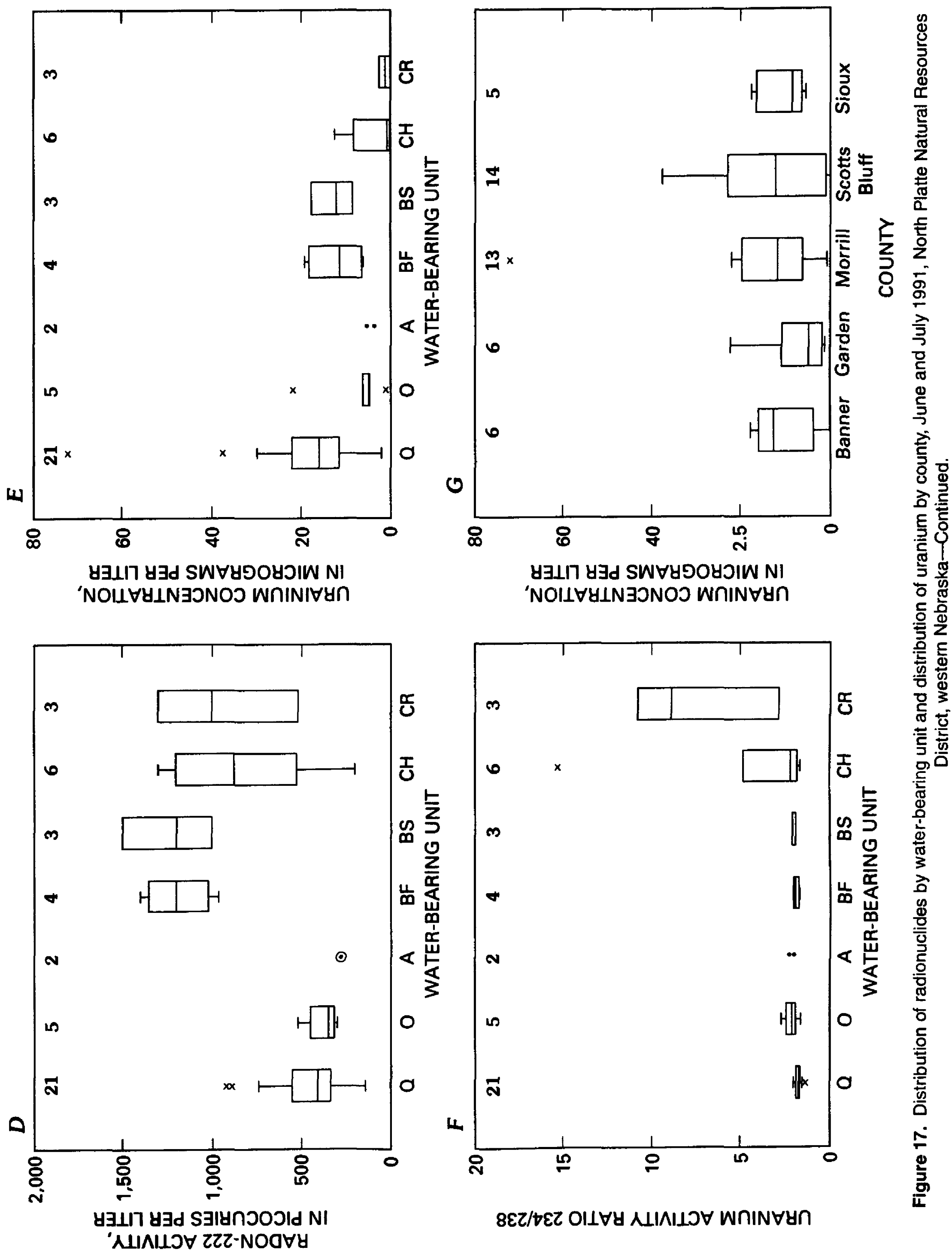
uranium-235. The primary gross-beta emitters from human sources are strontium-90, tritium, iodine-131, and cesium-137, and from natural sources are radium-228 and lead-210.

Strontium-90 is a fallout product of atmospheric testing of nuclear weapons and does not occur naturally except where nuclear fission reactions have occurred in uranium-enriched deposits (Durrance, 1986) and where it has been distributed globally in trace amounts through atmospheric fallout.

The gross-alpha activity results varied from less than 0.4 to $69.9 \mathrm{pCi} / \mathrm{L}$ (table 8 ). The grossbeta activities varied from 3.5 to $26 \mathrm{pCi} / \mathrm{L}$ (table 8 ). The Kruskal-Wallis test (statistical alpha $=0.001$ ) indicates that the distribution of gross-alpha activities was not the same in water from all waterbearing units. Water from the sand water-bearing units of the Brule Formation had the largest median gross-alpha activity ( $14 \mathrm{pCi} / \mathrm{L}$ gross alpha)

(table 13). At least 11 wells, mainly completed in the Quaternary-age water-bearing units, exceeded the $\mathrm{MCL}$ of $15 \mathrm{pCi} / \mathrm{L}$ for adjusted gross-alpha activity. The generally larger gross-beta activities of the water in Quaternary-age water-bearing units indicate that the water is young.

\section{Radon-222}

Radon-222 is a naturally occurring, radioactive noble gas, which is a degradation product in the uranium-238 decay chain (fig. 18). Radon-222 has a half-life of 3.8 days, which is longer-lived than other radon isotopes with half-lives of less than a minute (Hem, 1985). The mobility of radon is affected by physical processes. Radon- 222 can be adsorbed by organic matter and is soluble in water and organic liquids, but it readily degases from water into the atmosphere as a result of its low partial pressure in air. Radon concentrations, both in indoor air and in water, have become a concern in Nebraska. Substantial amounts of radon have been measured both in municipal water supplies and in indoor air (A.M. Pour, Nebraska Department of Health, oral commun., 1992).

The activities of radon-222 measured in this study varied from $140+/-24 \mathrm{pCi} / \mathrm{L}$ to $1,500+/-31 \mathrm{pCi} / \mathrm{L}$, with a median activity of $500 \mathrm{pCi} / \mathrm{L}$ (table 8 and figure 19). Significantly different radon activities were detected in water from Brule fractured-bedrock and sand waterbearing units, which contain volcanic ash, a probable radon source, than the levels of radon-222 detected in the other water-bearing units (table 16 and figure 17). Water from 39 wells completed in all water-bearing units, except in the Arikaree Group water-bearing units, exceeded the proposed $300 \mathrm{pCi} / \mathrm{L}$ MCL for radon-222 in water (fig. 19).

\section{Radium-226}

Radium-226 and radium-228 are naturally occurring radioactive isotopes. Radium-226 is of special concern because of its long half-life (1,600 years) and large specific activity. Radium tends to become concentrated in bones, similar to calcium. Radium tends to react like alkaline earth elements and can form strong complexes with sulfate and carbonate and weaker complexes with chloride and dissolved nitrate (Hem, 1985; Agency for Toxic Substances and Disease Registry, 1990).

The 44 water samples analyzed for radium-226 showed activities ranging from 0.04 $+/-0.01$ to $0.29+/-0.05 \mathrm{pCi} / \mathrm{L}$ with a median range of $0.12 \mathrm{pCi} / \mathrm{L}$ (table 8 and figure 17). Additional data on the activity of radium-228 needs to be collected to analyze whether the MCL of radium has been exceeded. Radium-226 activities in the water-bearing units were not significantly different from each other (table 16).

\section{Total Uranium and Uranium Activity Ratio 234/238}

In the Earth's crust, uranium exists in the forms of uranium-238, uranium-235, and uranium-234. In this report uranium results are presented as total uranium in micrograms per liter and the ratio of the activities of the two isotopes uranium-234 to uranium-238. Overall, the total-uranium concentration in ground water varied from less than 0.1 to $72 \mu \mathrm{g} / \mathrm{L}$, with a median of $11 \mu \mathrm{g} / \mathrm{L}$ and a standard deviation of $13 \mu \mathrm{g} / \mathrm{L}$ (table 5 ). The uranium $234 / 238$ activity ratios varied from 1.43 to 15.4 . The largest median total-uranium concentrations were detected in water from Quaternary-age water-bearing units, with a median of $16 \mu \mathrm{g} / \mathrm{L}$ and in water from the fractured-bedrock and sand water-bearing units of the Brule Formation with median concentrations of $11 \mu \mathrm{g} / \mathrm{L}$ (tables 9,12 , and 13). Wells $Q 32$ and $Q 98$ had the largest total- 


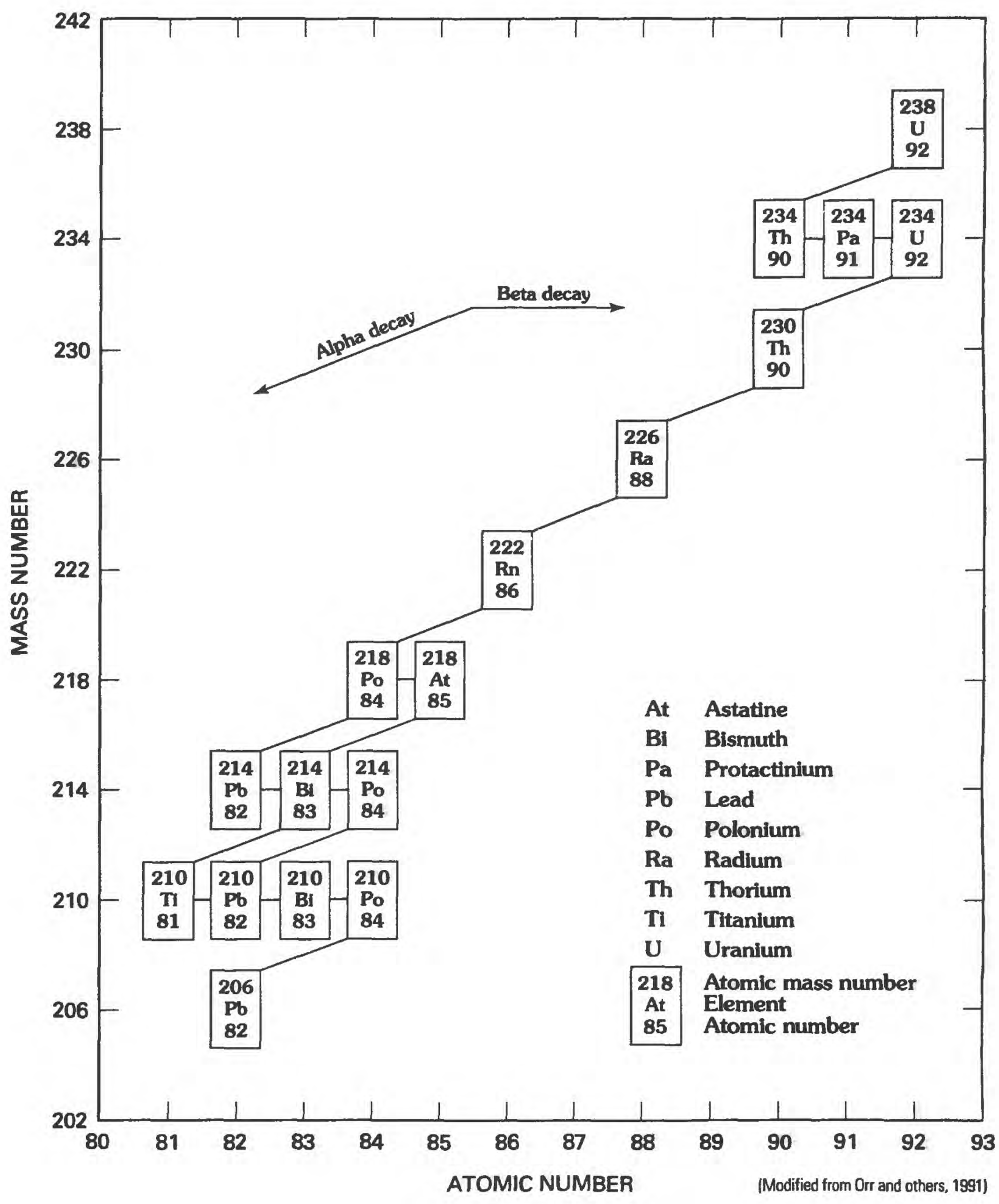

Figure 18. Uranium-238 radioactive decay series. 


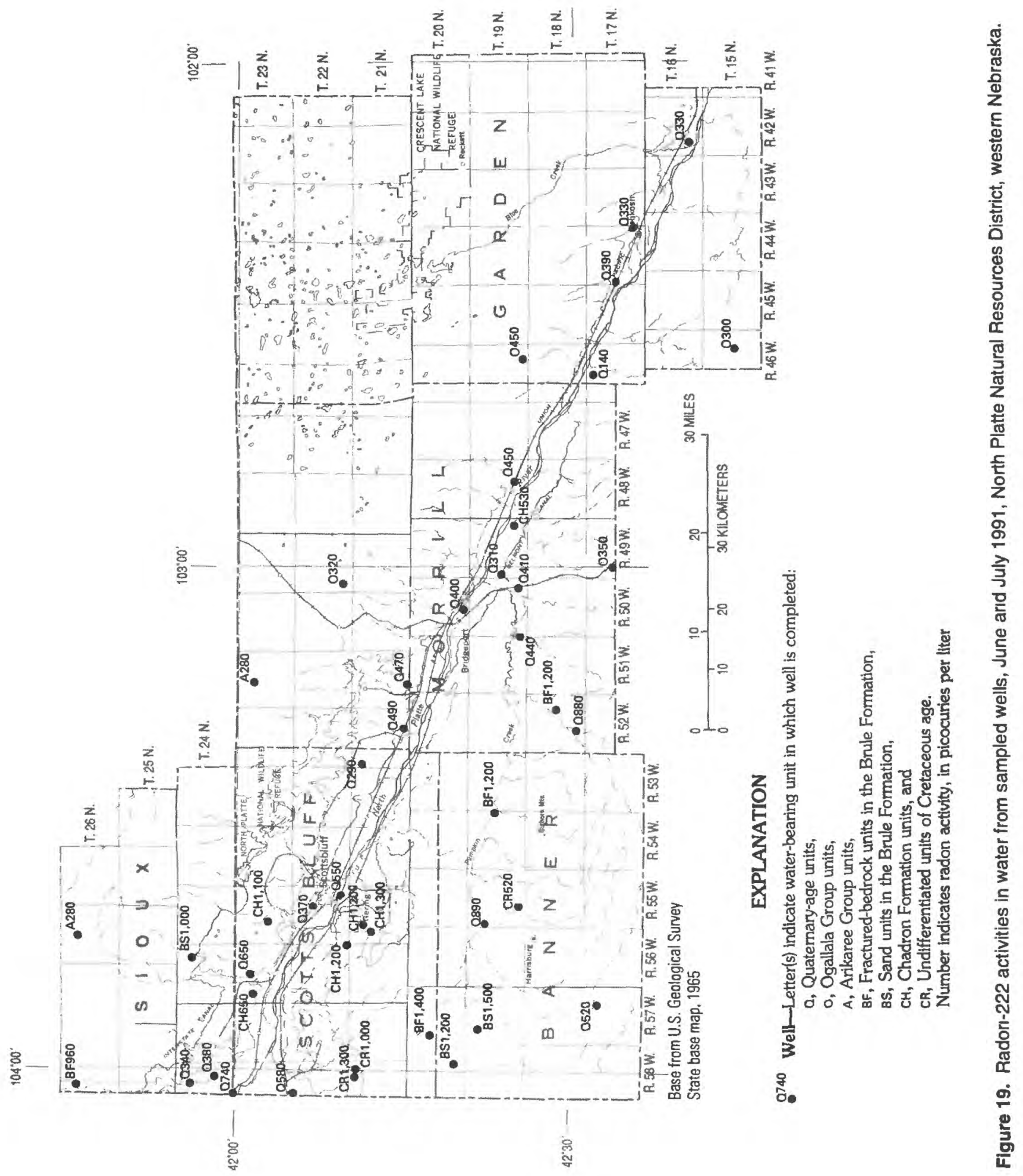


uranium concentrations ( 72 and $38 \mu \mathrm{g} / \mathrm{L}$, respectively). The smallest median concentrations of total uranium were detected in Chadron Formation water-bearing units and undifferentiated water-bearing units of Cretaceous age ( 0.8 and $1.2 \mu \mathrm{g} / \mathrm{L}$, respectively) (tables 14 and 15 ). Garden County had the smallest and Banner County had the highest median concentration of total uranium in ground water by county (fig. 17). The MCL for total uranium is $20 \mu \mathrm{g} / \mathrm{L}$. This concentration was exceeded in nine wells (Q7, Q21, Q32, O53, Q79, $\mathrm{Q} 84, \mathrm{Q} 86, \mathrm{Q} 89$, and Q98 with uranium concentrations of $22.3,20.7,72,22,24.9,30,22.1,21.8$, and $38 \mu \mathrm{g} / \mathrm{L}$, respectively), which consist of one industrial well, three municipal wells, and five irrigation wells.

The median uranium activity ratio $234 / 238$ in the water from the undifferentiated water-bearing units of Cretaceous age was the largest (8.9), and the median uranium ratio in the water from the Quaternary-age water-bearing units was the smallest (1.8) (tables 15 and 9, respectively). A high uranium ratio in the Chadron Formation waterbearing units and undifferentiated water-bearing units of Cretaceous age could indicate local uranium mineralization. Uranium is soluble as $\mathrm{U}^{6+}$ under oxidizing conditions and is practically insoluble in its reduced form, where the oxidation state is $\mathrm{U}^{4+}$ (Hem, 1985). The larger concentrations of dissolved uranium in the unconfined water-bearing units compared to the smaller concentrations of dissolved uranium in the confined water-bearing units could be explained by the assumed respective oxidizing and reducing environments within the water-bearing units as indicated by their respective large and small dissolved-oxygen concentrations. The assumption of reducing conditions in the Chadron Formation water-bearing units and undifferentiated waterbearing units of Cretaceous age is further supported by the elevated $\mathrm{U}^{234} / \mathrm{U}^{238}$ activity ratios, which indicate that most of the uranium is in the solid phase.

In general, uranium is attributed to the presence of uranium-bearing minerals in igneous rocks, sedimentary ore bodies, and phosphate rocks and its weathered products (Maynard, 1983). High concentrations of uranium are known to occur in the fractured-bedrock and sand water-bearing units of the Brule Formation and Chadron Formation water-bearing units north of the study area (Dickinson, 1991). The Chadron Formation water-bearing units contain abundant quantities of rhyolitic ash partially altered to smectites and other silicates (Dickinson, 1991). Uranium minerals are found mainly in the coarse-grained arkosic sandstone member of the Chadron Formation water-bearing units.

Water from Quaternary-age water-bearing units with larger uranium concentrations may be related to the presence of weathered granite and reworked volcanoclastics from Tertiary deposits or to surface and ground-water interaction with water of the North Platte River. High levels of uranium are present in the North Platte River (D.D. Snow, Institute of Agriculture and Natural Resources, University of Nebraska-Lincoln, written commun., 1993). In addition, it has been suggested that the larger uranium concentrations in the Quaternary deposits may originate from leachates from nonpoint sources downstream and downgradient of irrigated cropland and, at depth, from mobilization of uranium in water from pre-Quaternary strata (Spalding and Druliner, 1981).

\section{SUMMARY AND CONCLUSIONS}

The ground-water quality of the North Platte Natural Resources District in western Nebraska was statistically evaluated on the basis of data collected in June and July 1991 from 120 systematically selected wells completed in the unconfined Quaternary-age, Ogallala Group, and Arikaree Group water-bearing units, fractured-bedrock and sand water-bearing units of the Brule Formation, Chadron Formation water-bearing units, and undifferentiated water-bearing units of Cretaceous age. Analyses of water samples from all 120 wells included determination of dissolved nitrate plus nitrite as nitrogen and triazine and acetanilide herbicides. A subset of 46 water samples was analyzed for total carbamate insecticides, and 30 water samples were qualitatively analyzed for 2,4-D and related chlorophenoxy-acid compounds. Water-quality analyses of a subset of 44 water samples included dissolved major cations and anions, major metals, trace elements, and radionuclides. 
The prevalent use of fertilizers, herbicides, and insecticides in the North Platte Valley combined with relatively flat topography, irrigated cropland (mainly corn), and shallow depth to ground water mainly in the Quaternary-age water-bearing units has led to relatively large concentrations of dissolved nitrate and herbicides in ground water of the North Platte Valley. Herbicides detected during the study were alachlor, atrazine, prometon, and the atrazine metabolite, deethylatrazine. Insecticides were not detected during this study. The largest concentrations of dissolved nitrate and detections of herbicides occurred in an area surrounding Oshkosh in Garden County and between Bridgeport and Scottsbluff in the North Platte Valley. Herbicides were detected only in ground water from the Quaternary-age and Ogallala Group water-bearing units and sand water-bearing units of the Brule Formation. In addition, concentrations of dissolved nitrate in water from more than 75 percent of the wells were equal to or less than $6.0 \mathrm{mg} / \mathrm{L}$ as $\mathrm{N}$. Water samples collected from the confined Chadron Formation water-bearing units and undifferentiated waterbearing units of Cretaceous age had concentrations of dissolved nitrate plus nitrite as nitrogen generally less than the detection level, which may indicate the presence of a reducing environment disassociating the dissolved nitrate ion as supported by the low dissolved-oxygen concentrations detected in the water of these units or reduced leaching at depth because of the presence of confining layers.

Results of $\mathbf{4 4}$ ground-water samples showed statistically significant differences in major, trace, and radionuclide constituent concentrations and activities between confined and unconfined waterbearing units. Overall, the chemical quality of the ground water falls into two groups. The unconfined water-bearing units generally contain water of a calcium bicarbonate type, with moderate hardness and large dissolved-oxygen concentrations, which indicate mainly oxidizing conditions. The Chadron Formation water-bearing units and undifferentiated water-bearing units of Cretaceous age contain soft, mineralized water of a sodium bicarbonate type. The high degree of mineralization and high sodium but low calcium concentrations are generally an indication of the older age of the water, allowing the exchange of calcium and magnesium for sodium in geologic strata rich in clay minerals. These Chadron Formation water-bearing units and undifferentiated water-bearing units of Cretaceous age also exhibit small dissolved-oxygen and sulfate and high iron concentrations, which could indicate reducing conditions.

The distribution of concentrations of all major ions except potassium, sulfate, and chloride in the Chadron Formation water-bearing units and undifferentiated water-bearing units of Cretaceous age was not the same as in water from the other water-bearing units. The Quaternary-age waterbearing units generally contain hard water, with distributions of concentrations of calcium, magnesium, potassium, and sulfate concentrations differing from those in water from the other water-bearing units. Water from all water-bearing units in the study area is alkaline, with the $\mathrm{pH}$ ranging from 7.2 to 9.1 standard units. Nonpointsource contamination with agricultural chemicals of water from the Quaternary-age water-bearing units and to a lesser extent the fractured-bedrock and sand water-bearing units of the Brule Formation may contribute to the variability in constituent concentrations, and, locally, large sulfate and potassium concentrations.

The distribution of gross-beta activities was significantly different in water from the Quaternary-age water-bearing units as compared to water from the other water-bearing units. The generally larger gross-beta activities of the water in the Quaternary-age water-bearing units suggest that the water is relatively young. Water from the fractured-bedrock and sand water-bearing units of the Brule Formation did not have the same distribution of radon-222 activities as the water from the other water-bearing units. Median total-uranium concentrations and gross alpha were largest in water from the Quaternary-age water-bearing units and sand water-bearing units of the Brule Formation. The median uranium ratio 234/238 was largest in water from the undifferentiated water-bearing units of Cretaceous age. Again, the low concentrations of uranium but high uranium $234 / 238$ activity ratios indicate reducing conditions in the Chadron Formation and undifferentiated water-bearing units of Cretaceous age. The higher concentrations of uranium in the Quaternary-age water-bearing units may be related to the presence 
of weathered granite or Tertiary volcanoclastics in the Quaternary-age sediments or to ground- and surface-water interaction along the North Platte River.

Although some of the shallow ground water in and near the North Platte Valley may have been affected by additions of dissolved nitrate to the soil and point-source contamination by pesticides, the overall water quality of the unconfined waterbearing units generally is suitable for most uses. Ground water did not exceed the MCL's established by the USEPA for herbicides and insecticides, but water exceeded the MCL of $10 \mathrm{mg} / \mathrm{L}$ of dissolved nitrate plus nitrite as nitrogen from six wells completed in Quaternary-age and fractured-bedrock water-bearing units of the Brule Formation. Other MCL and SMCL exceedances included:

(1) pH SMCL of 8.5 standard units was exceeded in water from two wells completed in the Chadron Formation water-bearing units, three wells completed in the undifferentiated water-bearing units of Cretaceous age, and two wells completed in the Quaternary-age waterbearing units;

(2) Calculated dissolved solids SMCL of $500 \mathrm{mg} / \mathrm{L}$ was exceeded in water from 20 wells completed in the Quaternary-age alluvial, Chadron Formation, and undifferentiated water-bearing units of Cretaceous age;

(3) Sulfate SMCL of $250 \mathrm{mg} / \mathrm{L}$ was exceeded in water from three wells completed in Quaternary-age water-bearing units;

(4) Chloride SMCL of $250 \mathrm{mg} / \mathrm{L}$ was exceeded in water from two wells completed in the Chadron Formation water-bearing units;

(5) Fluoride SMCL of $2.0 \mathrm{mg} / \mathrm{L}$ was exceeded in water from two wells completed in the Chadron Formation water-bearing units;

(6) Arsenic MCL of $50 \mu \mathrm{g} / \mathrm{L}$ was exceeded in water from one well completed in the Chadron Formation water-bearing units;

(7) Beryllium proposed MCL of $1.0 \mu \mathrm{g} / \mathrm{L}$ was exceeded in two wells completed in the Chadron Formation water-bearing units;

(8) Manganese SMCL of $50 \mu \mathrm{g} / \mathrm{L}$ was exceeded in water from two wells completed in Quaternary-age water- bearing units;

(9) Adjusted gross alpha MCL of $15 \mathrm{pCi} / \mathrm{L}$ was exceeded in at least 11 wells, mainly. completed in Quaternary-age waterbearing units;

(10) Radon-222 proposed MCL of $300 \mathrm{pCi} / \mathrm{L}$ was exceeded in 39 of the 44 selected wells completed in all units, except in the Arikaree Group water-bearing units; and

(11) Uranium MCL of $20 \mu \mathrm{g} / \mathrm{L}$ was exceeded in nine wells completed in Quaternary-age alluvial and Ogallala Group water-bearing units.

The quality of water from the Chadron Formation water-bearing units and undifferentiated water-bearing units of Cretaceous age generally is not well suited for domestic and irrigation water use because of the large chloride and fluoride concentrations, percentage of sodium, and large sodium-adsorption ratio. In addition, the use of water for irrigation with large calculated dissolvedsolids concentrations can adversely affect crops.

Even though water from the unconfined units in the North Platte Natural Resources District is generally suitable for most uses, the presence of manmade chemicals, such as dissolved nitrate and herbicides, and the selected major-ion concentrations indicate that the water in the unconfined water-bearing units could degrade in the future if current agricultural practices of chemical additions to the land surface continue.

\section{REFERENCES}

Ahlbrandt, T.S., Swinehart, J.B., and Maroney, D.G., 1983, The dynamic Holocene dunefields of the Great Plains and Rocky Mountain basins, U.S.A., in Brookfield, M.E., and Ahlbrandt, T.S., eds., Eolian sediments and processes: Amsterdam, Elsevier Publishers, p. 379-406.

Agency for Toxic Substances and Disease Registry, 1990, Toxicological profile for radium: U.S. Department of Health and Human Services, Public Health Service, TP-90-22, $131 \mathrm{p}$.

Baker, M., Peterson, N., and Kamble, S.T., 1990, Pesticide use on crops in Nebraska 1987: Agricultural Research Division, Institute of Agriculture and Natural Resources, University of Nebraska-Lincoln, Research Bulletin 311, 27 p.

Burchett, R.R. (compiler), 1986, Geologic bedrock map of Nebraska: University of Nebraska-Lincoln, Institute of Agriculture and Natural Resources, Conservation and Survey Division, 1 sheet, scale $1: 1,000,000$. 
Clerk of the Legislator, 1991, Nebraska blue book 1990-91: p. 782-84.

Conservation and Survey Division, 1980a, Ground water nitrate-as-nitrogen concentrations, Scotts Bluff quadrangle: University of Nebraska-Lincoln, 1 sheet, scale $1: 250,000$. $1980 \mathrm{~b}$, Ground water nitrate-as-nitrogen concentrations, Alliance quadrangle: University of Nebraska-Lincoln, 1 sheet, scale 1:250,000.

Darton, N.H., 1903a, Geologic atlas of the United States, Scotts Bluff folio, Nebraska: U.S. Geological Survey Folio 88, 5 p.

1903b, Preliminary report on the geology and water resources of Nebraska west of the one-hundred and third meridian: U.S. Geological Survey Professional Paper 17, 69 p.

DeGraw, H.M., 1969, Subsurface relations of the Cretaceous and Tertiary in western Nebraska: University of Nebraska-Lincoln, Conservation and Survey Division Open-file report, $137 \mathrm{p}$.

Dickinson, K.A., 1991, Uranium diagenesis in evaporite lacustrine mudstone of the Oligocene White River Group, Dawes County, Nebraska: U.S. Geological Survey Bulletin 1956, 16 p.

Durrance, E.M., 1986, Radioactivity in geologyPrinciples and applications: New York, John Wiley and Sons, Inc., $441 \mathrm{p}$.

Durum, W.H., 1950 , Section on the chemical quality of the water, in Babcock, H.M., and Fisher, F.N., Reconnaissance of the geology and ground-water resources of the Dutch Flats area, Scotts Bluff and Sioux Counties, Nebraska: U.S. Geological Survey Circular 126, p. 16-22.

1952 , Section on the chemical quality of the water, in Babcock, H.M., and Fisher, F.N.,

Reconnaissance of the geology and ground-water resources of the Pumpkin Creek area, Morrill and Banner Counties, Nebraska: U.S. Geological Survey Circular 156, p. 16-21.

Elder, J.A., 1969, Soils of Nebraska: University of Nebraska-Lincoln Conservation and Survey Division Resource Report No. 2, 60 p.

Engberg, R.A., 1984, Appraisal of data for groundwater quality in Nebraska: U.S. Geological Survey Water-Supply Paper 2245, 54 p.

Engberg, R.A., and Druliner, A.D., 1987, Nebraska ground-water quality: U.S. Geological Survey Open-File Report 87-737, 9 p.

Engberg, R.A., and Spalding, R.F., 1979, Ground-water quality atlas of Nebraska: University of Nebraska, Conservation and Survey Division Resource Atlas $3,38 \mathrm{p}$.

Exner, M.E., 1990, An investigation to determine the source of elevated nitrate concentrations in the ground water of the North Platte Valley west of Oshkosh, Nebraska: Report for the North Platte Natural Resources District, February 26, 1990 , $23 \mathrm{p}$.

Fenneman, N.M., 1931, Physiography of western United States: New York, McGraw-Hill, Inc., p. 11.

Fishman, M.J., and Friedman, L.C., eds., 1989, Methods for determination of inorganic substances in water and fluvial sediments: U.S. Geological Survey,
Techniques of Water-Resources Investigations, book 5 , chap. Al, $545 \mathrm{p}$.

Freeze, R.A., and Cherry, J.A., 1979, Groundwater: Englewood Cliffs, N.J., Prentice Hall, Inc., 604 p.

Friedman, L.C., and Fishman, M.J., 1982, Quality assurance practices for the chemical and biological analyses of water and fluvial sediments: U.S. Geological Survey Techniques of WaterResources Investigations, book 5, chap. A6, $181 \mathrm{p}$.

Gormly, J.R., and Spalding, R.F., 1979, Sources and concentrations of nitrate as nitrogen in ground water of the Central Platte Region, Nebraska: Ground Water, v. 17, no. 3, p. 291-300.

Hallberg, G.R., 1989, Nitrate in ground water in the United States, in Follet, R.F., ed., Nitrogen management and ground water protection: Amsterdam, Netherlands, Elsevier, p. 35-74.

Hamilton, P.A., Shedlock, R.J., and Philips, P.J., 1991, Water-quality assessment of the Delmarva Peninsula, Delaware, Maryland, and VirginiaAnalysis of available ground-water quality data through 1987: U.S. Geological Survey Water-Supply Paper 2355, $65 \mathrm{p}$.

Helsel, D.R., and Gilliom, R.J., 1985, Estimation of distributional parameters for censored trace-level water-quality data-II, Verification and application: U.S. Geological Survey Open-File Report 85-86, $21 \mathrm{p}$.

Helsel, D.R., and Hirsch, R.M., 1992, Statistical methods in water resources: New York, Elsevier Publ., 522 p.

Hem, J.D., 1985, Study and interpretation of the chemical characteristics of natural water ( $3 \mathrm{~d}$ ed.): U.S. Geological Survey Water-Supply Paper 2254, $263 \mathrm{p}$.

Jones, B.E., 1987, Quality control manual of the U.S. Geological Survey's National Water Quality Laboratory: U.S. Geological Survey Open-File Report 87-457, 17 p.

Lawson, M.P., Dewey, K.F., and Neild, R.F., 1977, Climatic atlas of Nebraska: Lincoln, University of Nebraska Press, 88 p.

Maynard, J.B., 1983, Geochemistry of sedimentary ore deposits: New York, Springer-Verlag, p. 147-180.

Meriwether, J.R., Beck, J.N., Keeley, D.F., Langley, M.P., Thompson, R.H., and Young, J.L., 1988, Radionuclides in Louisiana soils: Journal of Environmental Quality, v. 17, no. 4, p. 562-567.

National Oceanic and Atmospheric Administration, 1982 , Monthly normals of temperature, precipitation, and heating and cooling degree days, 1951-1980, Nebraska: Asheville, NC, Environmental Data and Information Service, National Climatic Center, September 1982.

Nebraska Department of Agriculture, 1993, 1991/1992 Nebraska agricultural statistics: Nebraska Agricultural Statistics Service, $146 \mathrm{p}$. 
Orr, B.R., Cecil, L.D., and Knobel, L.L., 1991, Background concentrations of selected radionuclides, organic compounds, and chemical constituents in ground water in the vicinity of the Idaho National Engineering Laboratory: U.S. Geological Survey Water-Resources Investigation Report $91-4015,52 \mathrm{p}$.

Pritt, J.W., and Jones, B.E., eds., 1989, 1990 National Water Quality Laboratory Services Catalog: U.S. Geological Survey Open-File Report 89-386, $132 \mathrm{p}$.

Rainwater, F.H., 1956, A section on the chemical quality of ground water, in Bradley, Edward,

Reconnaissance of the geology and ground-water in southern Sioux County, Nebraska: U.S. Geological Survey Hydrologic Investigations Atlas HA-6, 2 plates, scale 1: 125,000 .

Smith, F.A., and Souders, V.L., 1975, Ground-water geology of Banner County, Nebraska: Lincoln, Nebraska Water Survey 39, $96 \mathrm{p}$.

Souders, V.L., 1986, Geologic sections, ground-water maps, and logs of test holes, Morrill County, Nebraska: University of Nebraska Conservation and Survey Division, Open-File Report, $90 \mathrm{p}$.

Spalding, R.F., 1991, Assessment of statewide ground-water quality-Data from domestic wells in rural Nebraska: Lincoln, Nebraska, Water Center/Water Science Laboratory in cooperation with the Nebraska Department of Health, Open-file report, $49 \mathrm{p}$.

Spalding, R.F., and Druliner, A.D., 1981, Ground-water uranium concentrations-How high is high?: Studies in Environmental Science, v. 17,6 p.

Spalding, R.F., and Exner, M.E., 1980, Areal, vertical, and temporal differences in ground-water chemistry-I. Inorganic constituents: Journal of Environmental Quality, v. 9, no. 3, p. 466-478.

Spalding, R.F., Gormly, J.R., Curtiss, B.H., and Exner, M.E., 1978, Non-point nitrate contamination of ground water in Merrick County, Nebraska: Ground Water, v. 16, no. 2, p. 86-95.

Spalding, R.F., and Kitchen, L.A., 1988, Nitrate in the intermediate vadose zone beneath irrigated cropland: Ground-Water Monitoring Review, v. 8, no. 2, p. 89-95.

Swinehart, J.B., Souders, V.L., DeGraw, H.M., and Diffendal, R.F., Jr., 1985, Cenozoic paleography of the western Nebraska, in Flores, R.M., and Kaplin, S.S., eds., Cenozoic paleogeography of west central United States: Denver, Colo., Rocky Mountain Section, Society of Economic Paleontology and Mineralogy, p. 209-229.

Thatcher, L.L, Janzen, L.J., and Edwards, K.N., 1977, Methods for determination of radioactive substances in water in fluvial sediments: U.S. Geological Survey Water-Resources Investigation 5, p. 93-95.

U.S. Department of Agriculture, 1992, Agricultural resources-Inputs, situation, and outlook report: Washington, D.C., Resources and Technology Division, Economic Research Service, U.S. Department of Agriculture, February 1992, AR-25, p. 2-18.
U.S. Department of Energy, 1981, Hydrogeochemical and stream sediment reconnaissance basic data for Scottsbluff Quadrangle, Nebraska and Colorado: Oak Ridge, Tenn., National Uranium Resource Evaluation Program, Oak Ridge Gaseous Diffusion Plant, $39 \mathrm{p}$.

U.S. Environmental Protection Agency, 1986, Advanced notice of proposed rulemaking, National primary drinking-water regulations-Radionuclides (section 141.50 of part 141): U.S. Federal Register, v. 51, no. 189, September 30, 1986 , p. $34,836-34,862$.

1988a, Maximum contaminant levels (subpart B of part 141, National primary drinking water regulations): U.S. Code of Federal Regulations, Title 40 , parts 100 to 149 , revised as of July 1 , 1988, p. 530-533.

1988b, Maximum contaminant level goals (subpart F of part 141, National interim primary drinkingwater regulations): U.S. Code of Federal Regulations, Title 40 , parts $100-149$, revised as of July 1,1988 , p. 585-586.

1988c, National revised primary drinking- water regulations, maximum contaminant levels (subpart $\mathrm{G}$ of part 141, National interim primary drinkingwater regulations): U.S. Code of Federal Regulations, Title 40 , parts 100 to 149 , revised as of July 1,1988 , p. 586-587.

1988d, Secondary maximum contaminant levels (sec. 143.3 of part 143, National secondary drinking-water regulations): U.S. Code of Federal Regulations, Title 40, parts 100 to 149 , revised as of July 1, 1988, p. 608.

1988e, Proposed rule, drinking-water regulationsMaximum contaminant level goals and National primary drinking-water regulations for lead and copper (subpart I of 141): U.S. Federal Register, v. 53, no. 160, August 18, 1988, p. 31, 516-31, 578 . 1989, Drinking water health advisory-Pesticides: Office of Drinking Water Advisories, Chelsea, Mich., Lewis Publishers, Inc., 819 p. 1991, Radionuclides in drinking water, Proposed Rule, June 1991: Office of Ground Water and Drinking Water, 570/9-91-700.

Wenzel, L.K., Cady, R.C., and Waite, H.A., 1946, Geology and ground-water resources of Scotts Bluff County, Nebraska: U.S. Geological Survey Water-Supply Paper 943, 150 p.

Whittaker, E.L., Akridge, J.D., and Giovino, J., 1989, Two test procedures for radon in drinking water: U.S. Environmental Protection Agency, EPA/600/2-87/082, March 1989, p. 2-10.

Wilson, R.G., 1979, Survey of pesticide use in irrigated regions of the Nebraska Panhandle: Agricultural Experiment Station, Institute of Agriculture and Natural Resources, University of Nebraska-Lincoln, $19 \mathrm{p}$. 


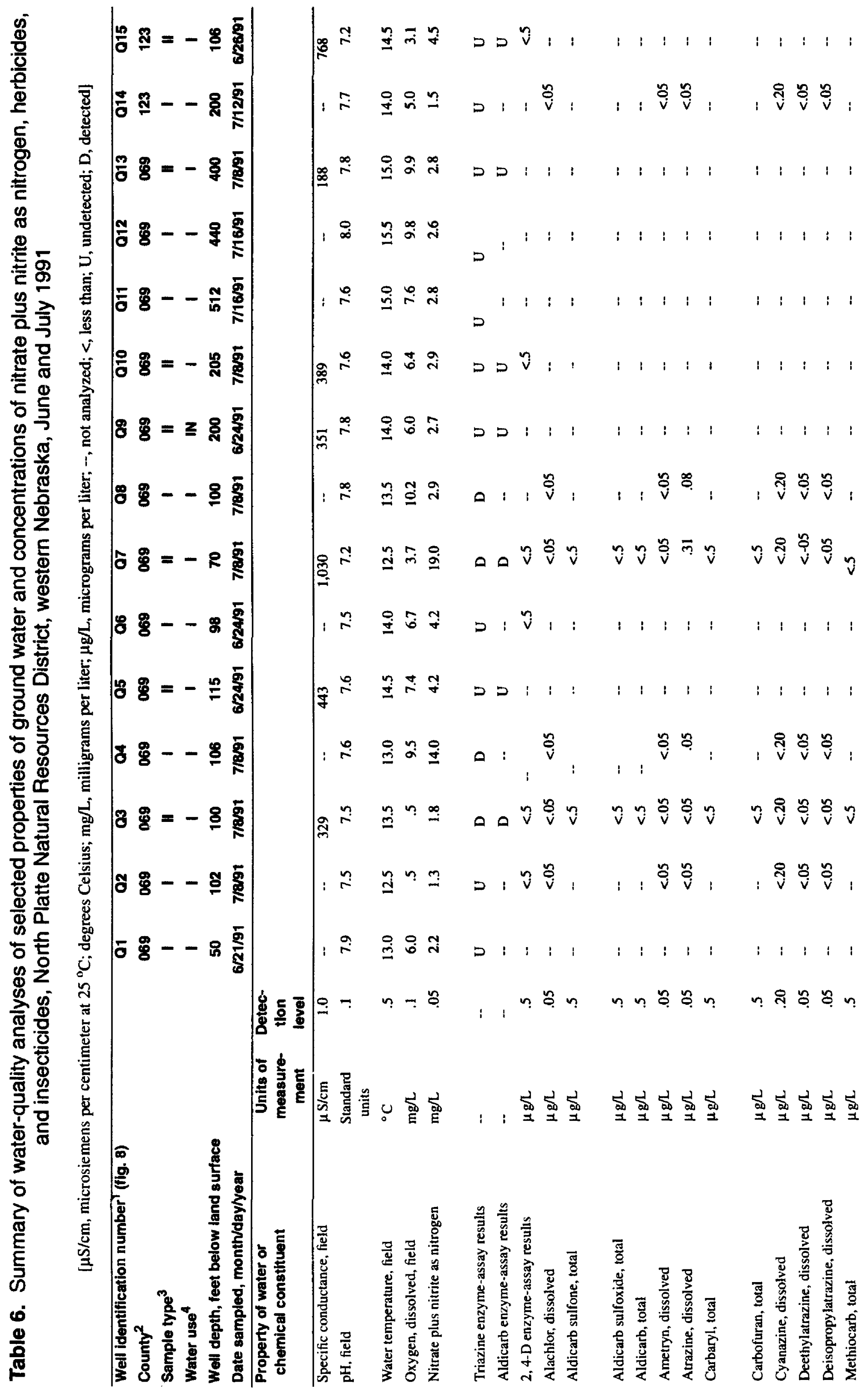




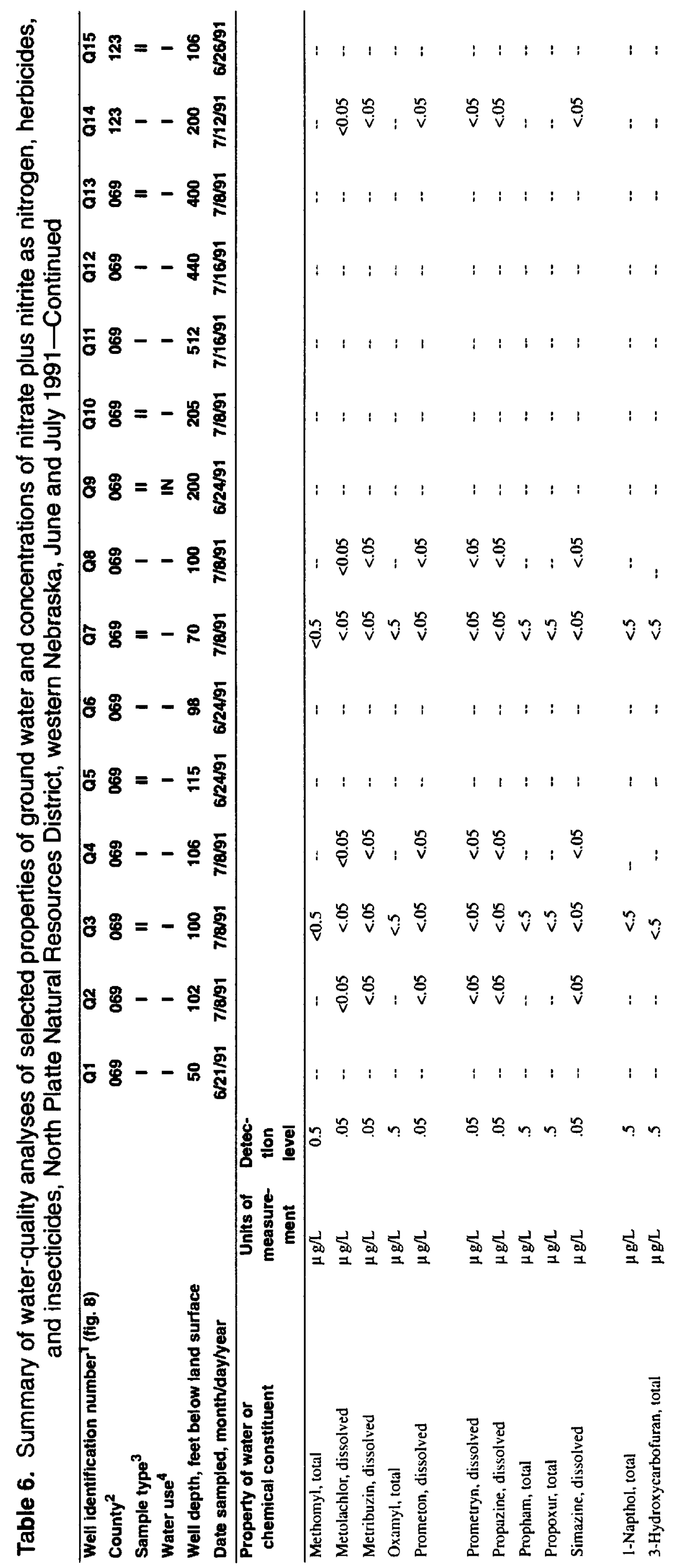




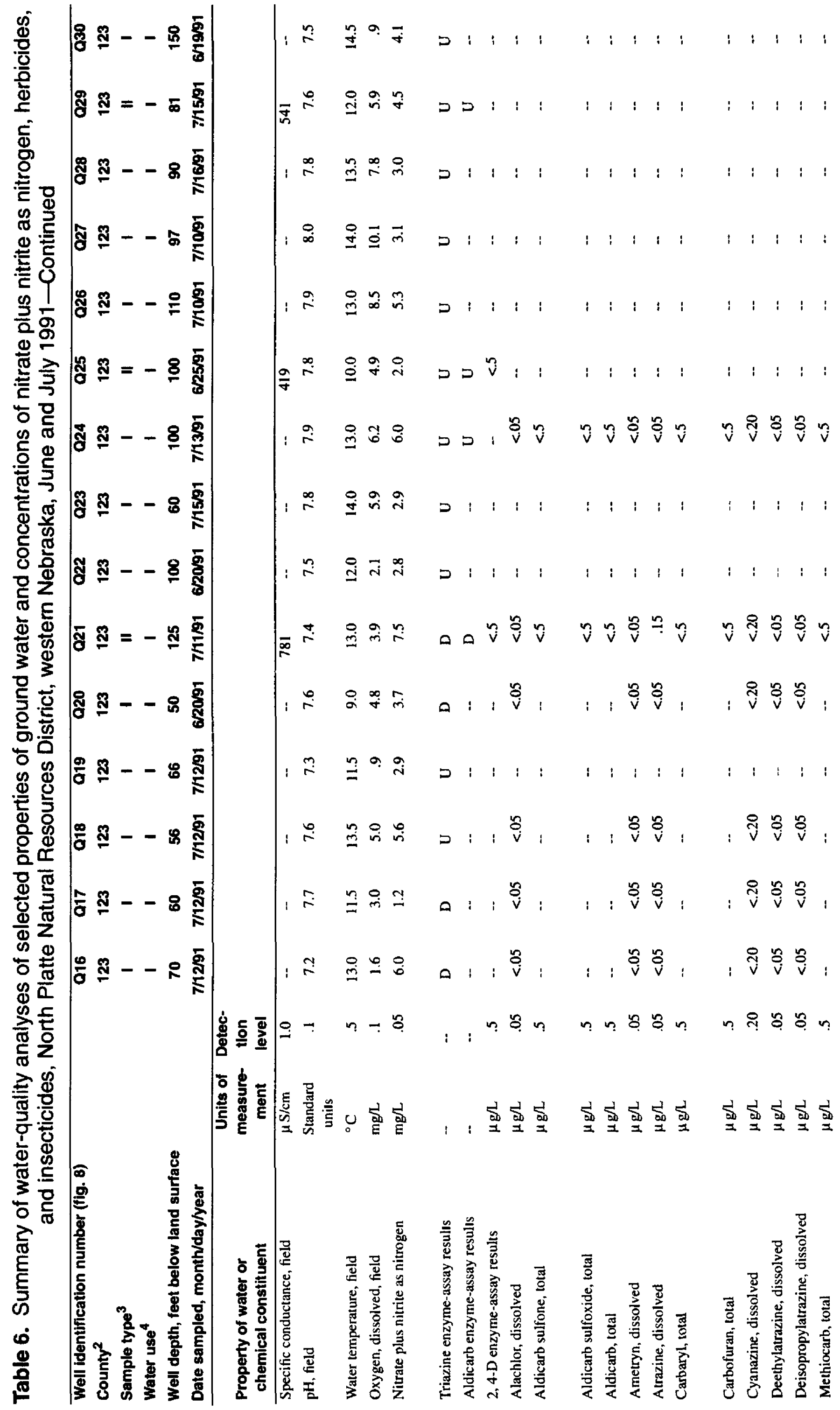




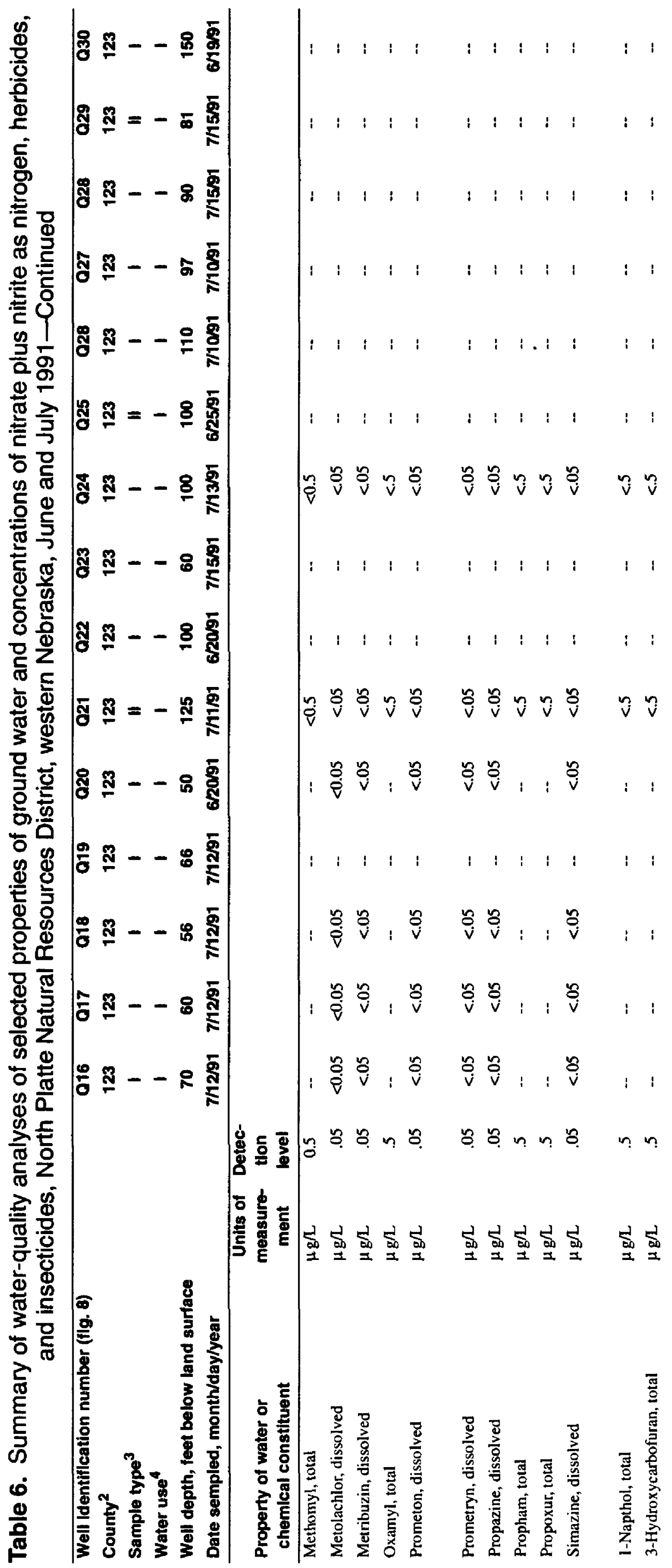




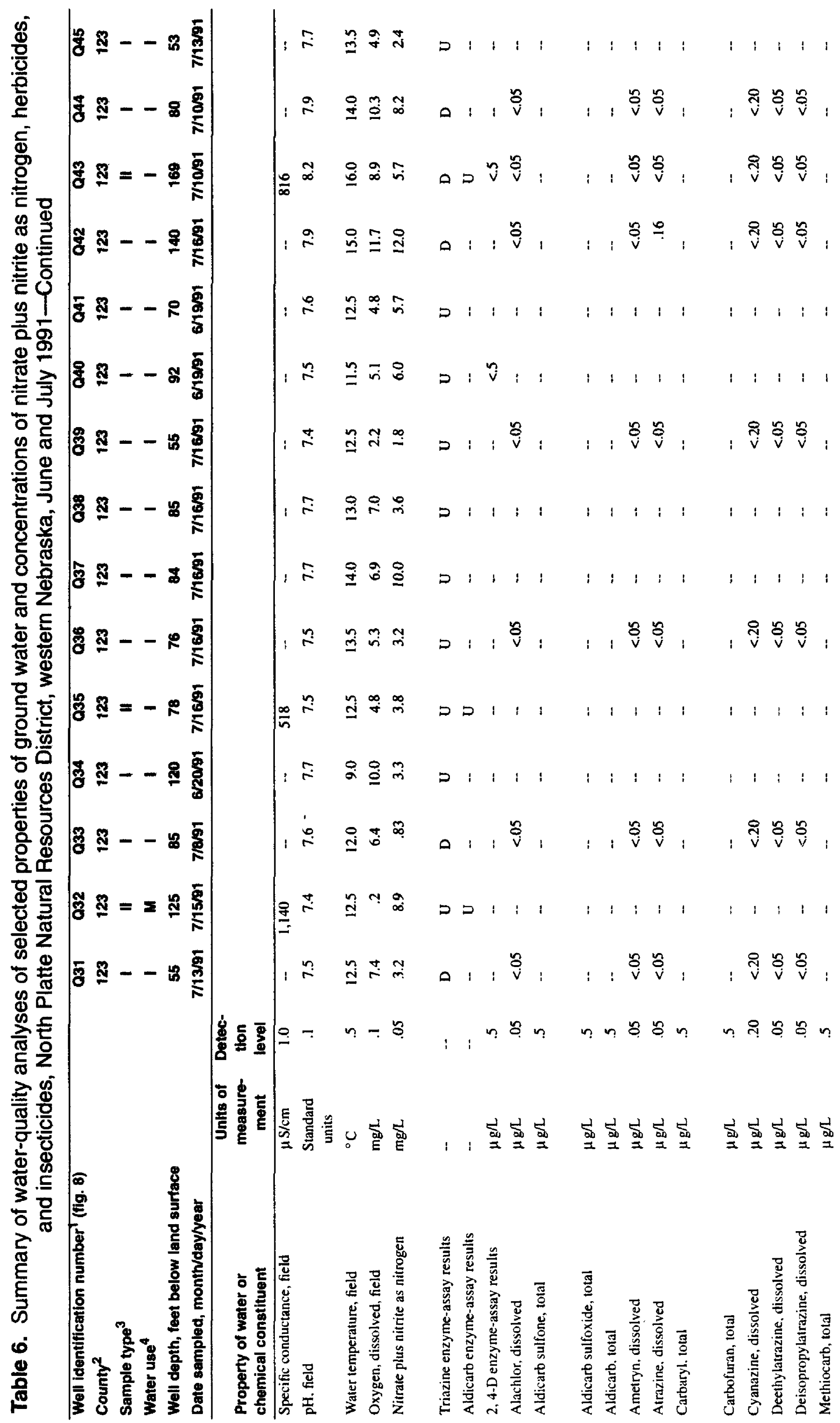




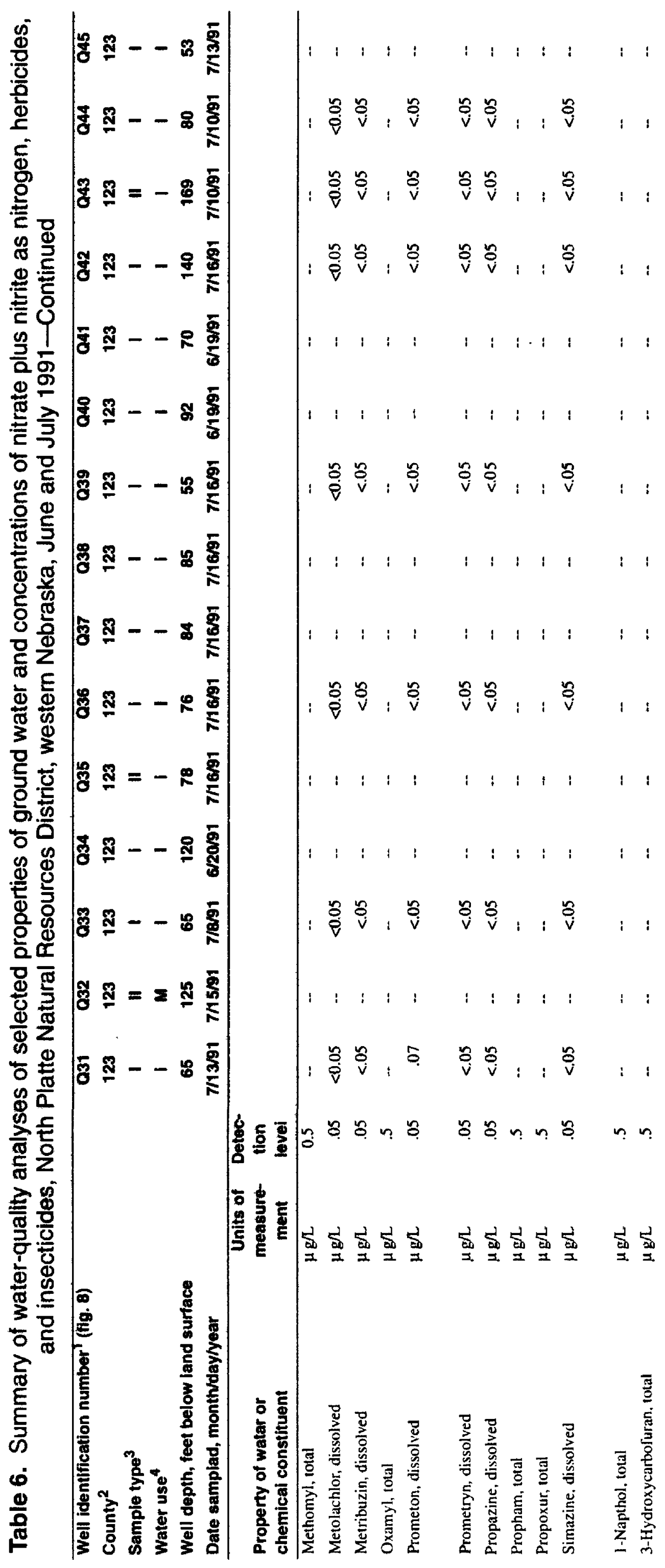




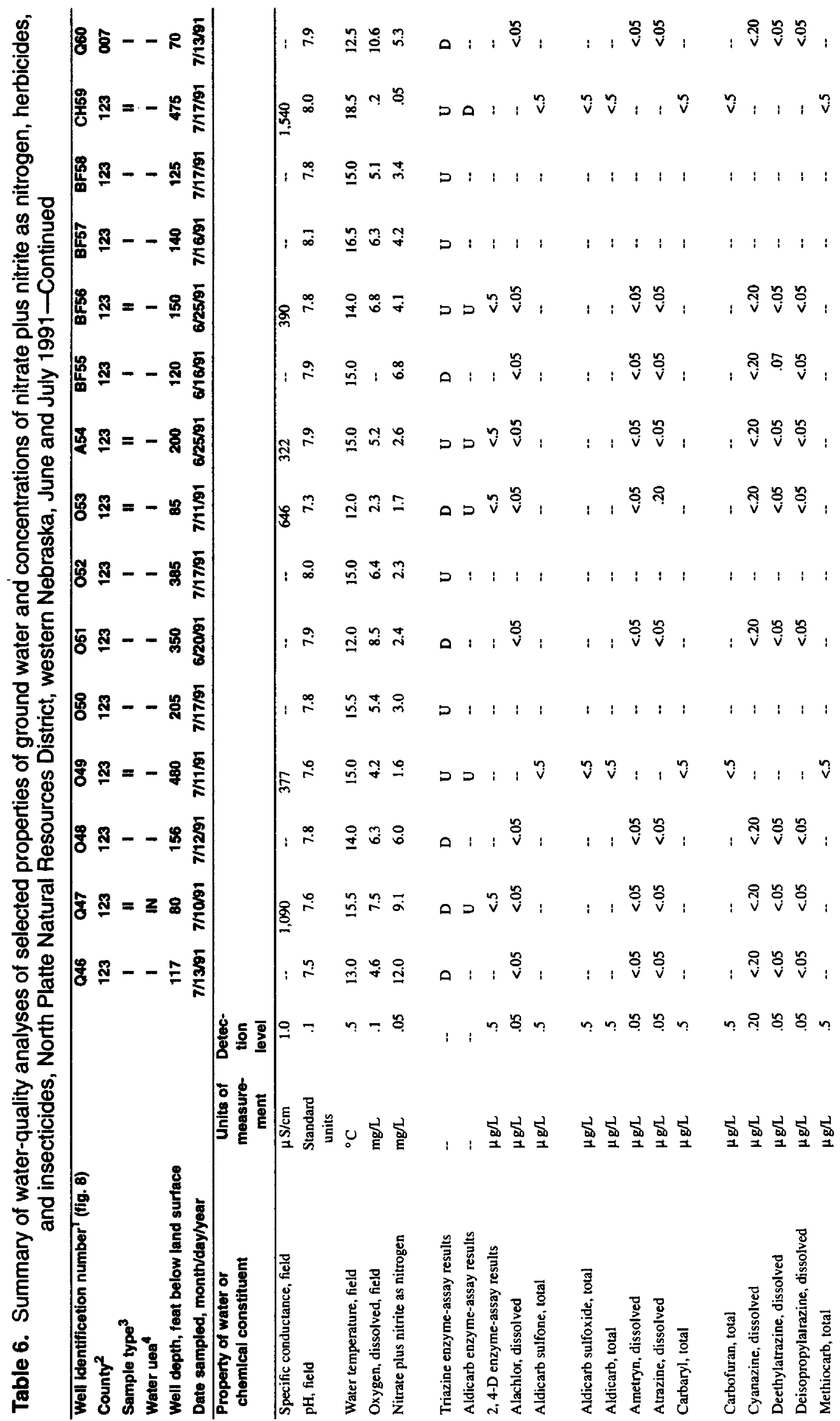




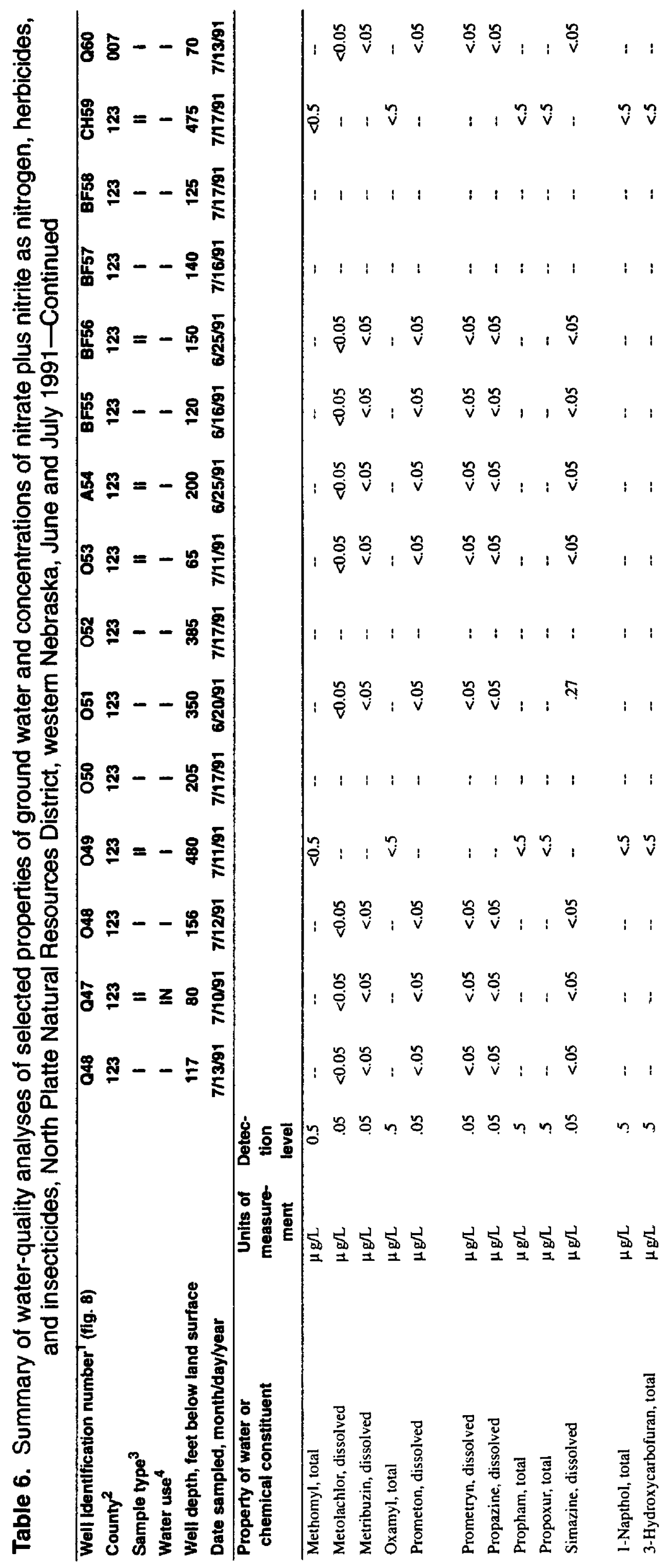




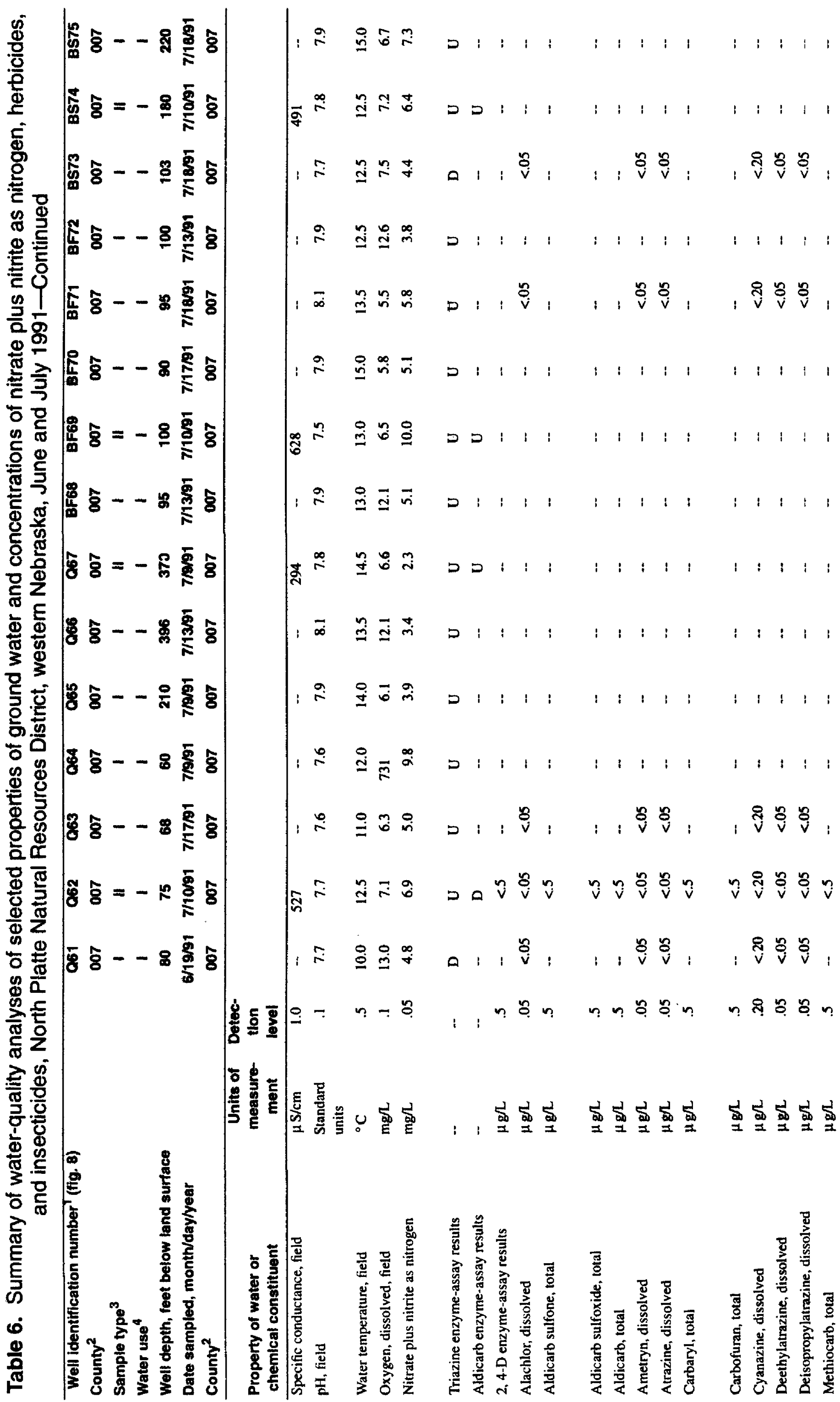




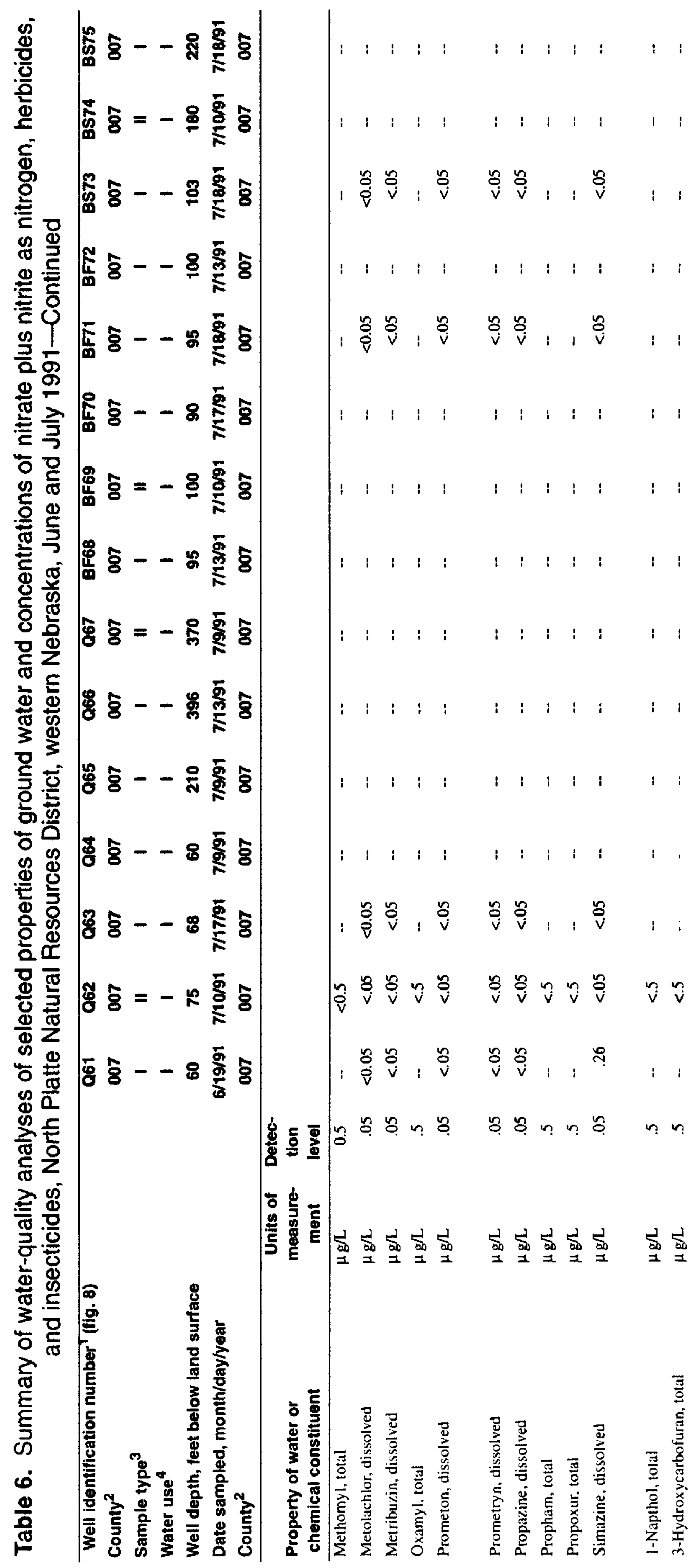




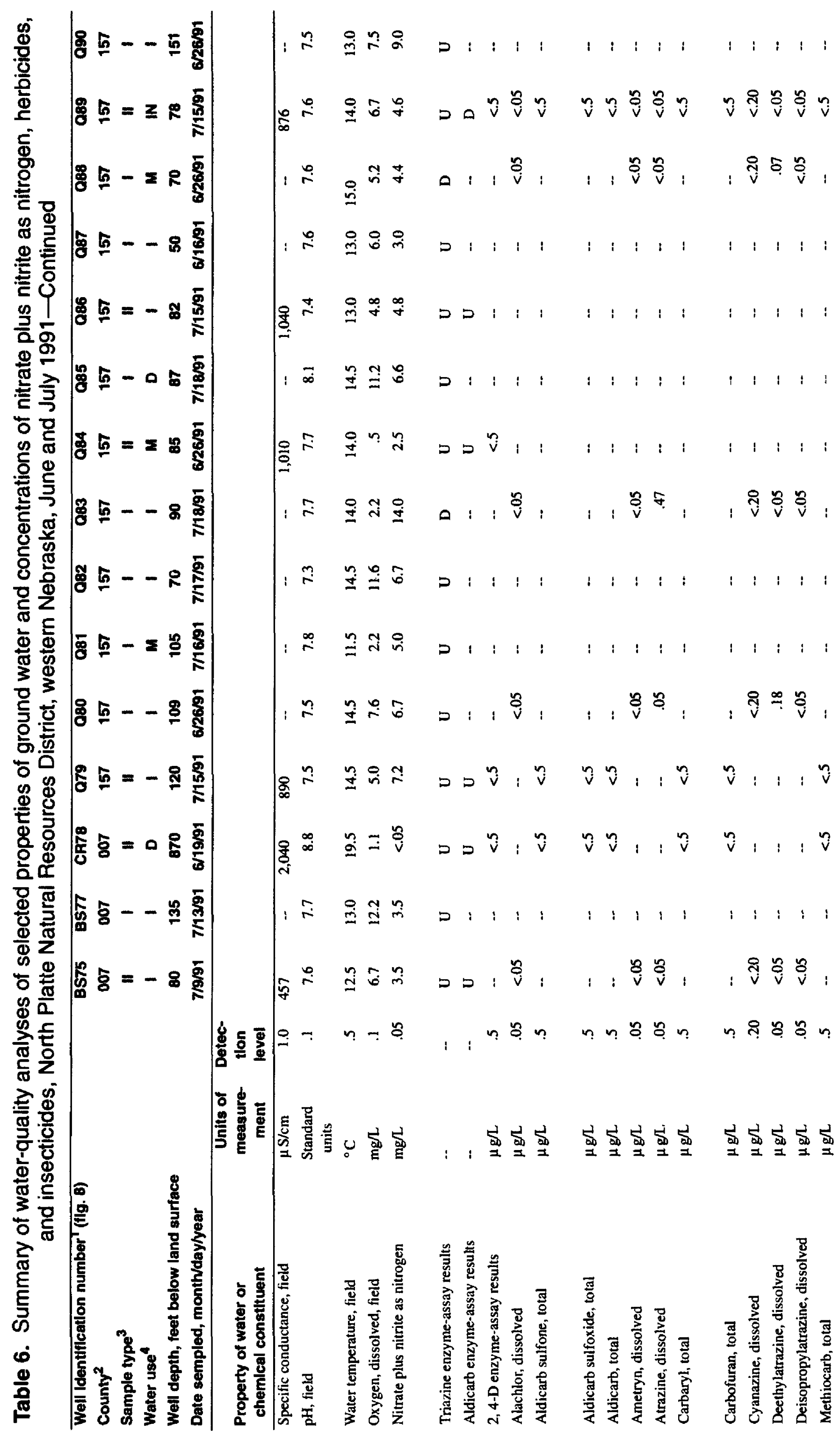




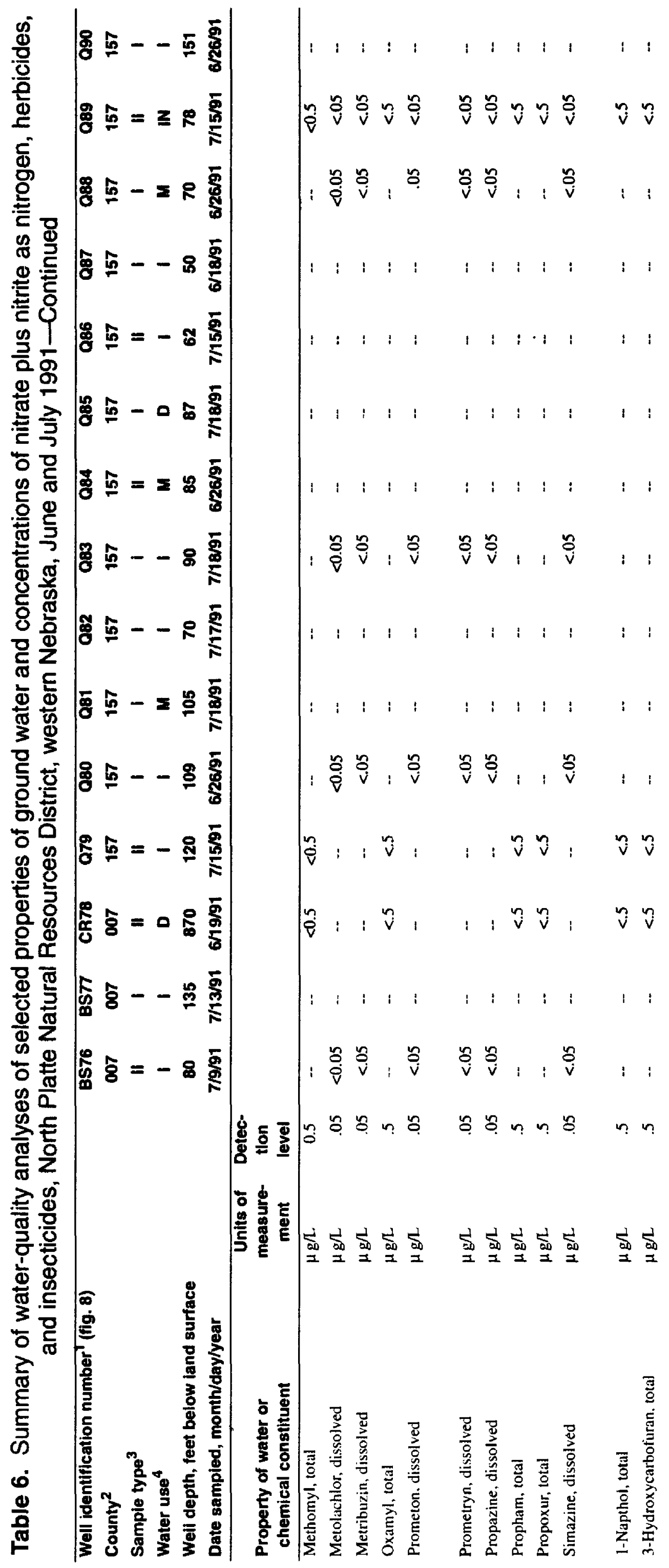




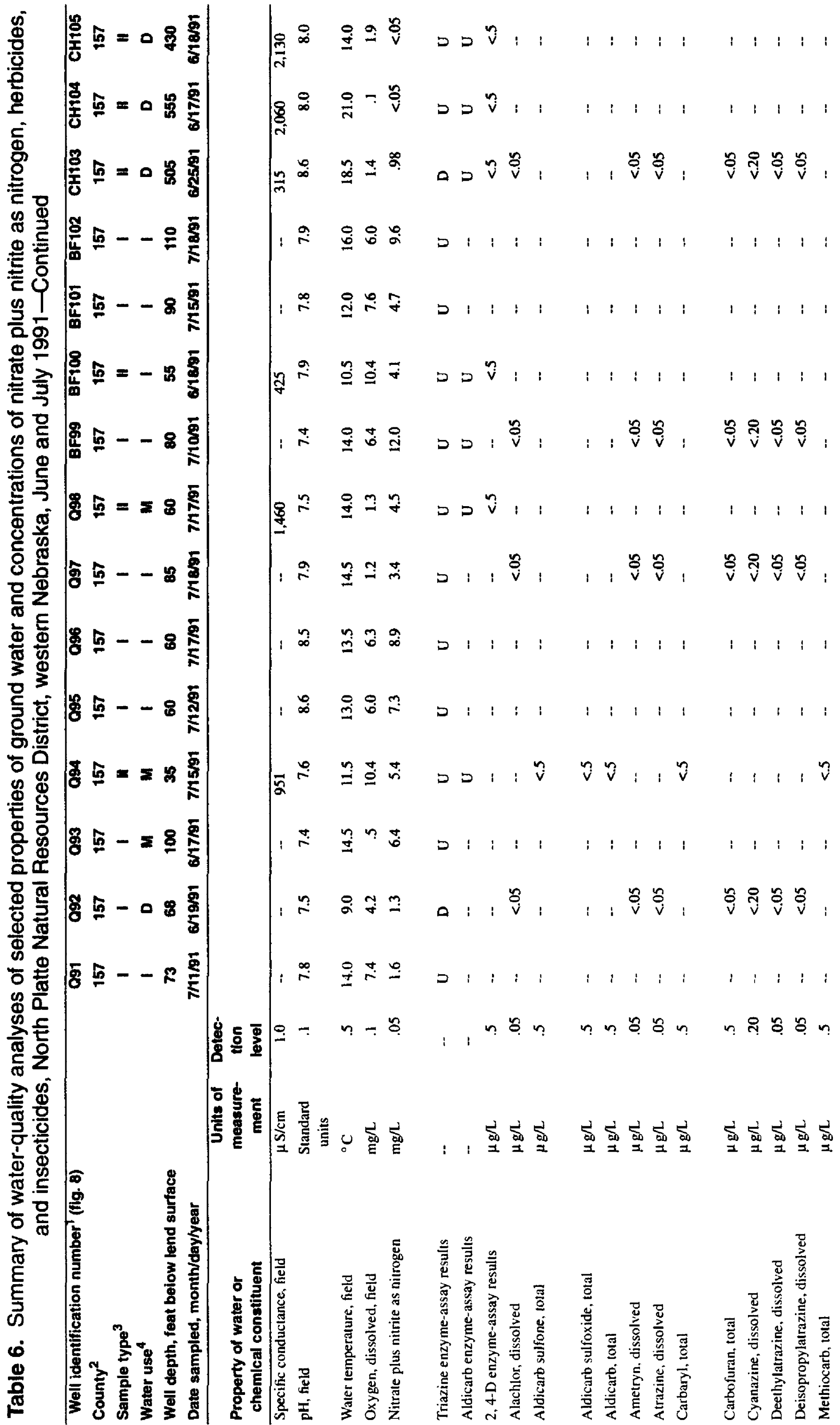




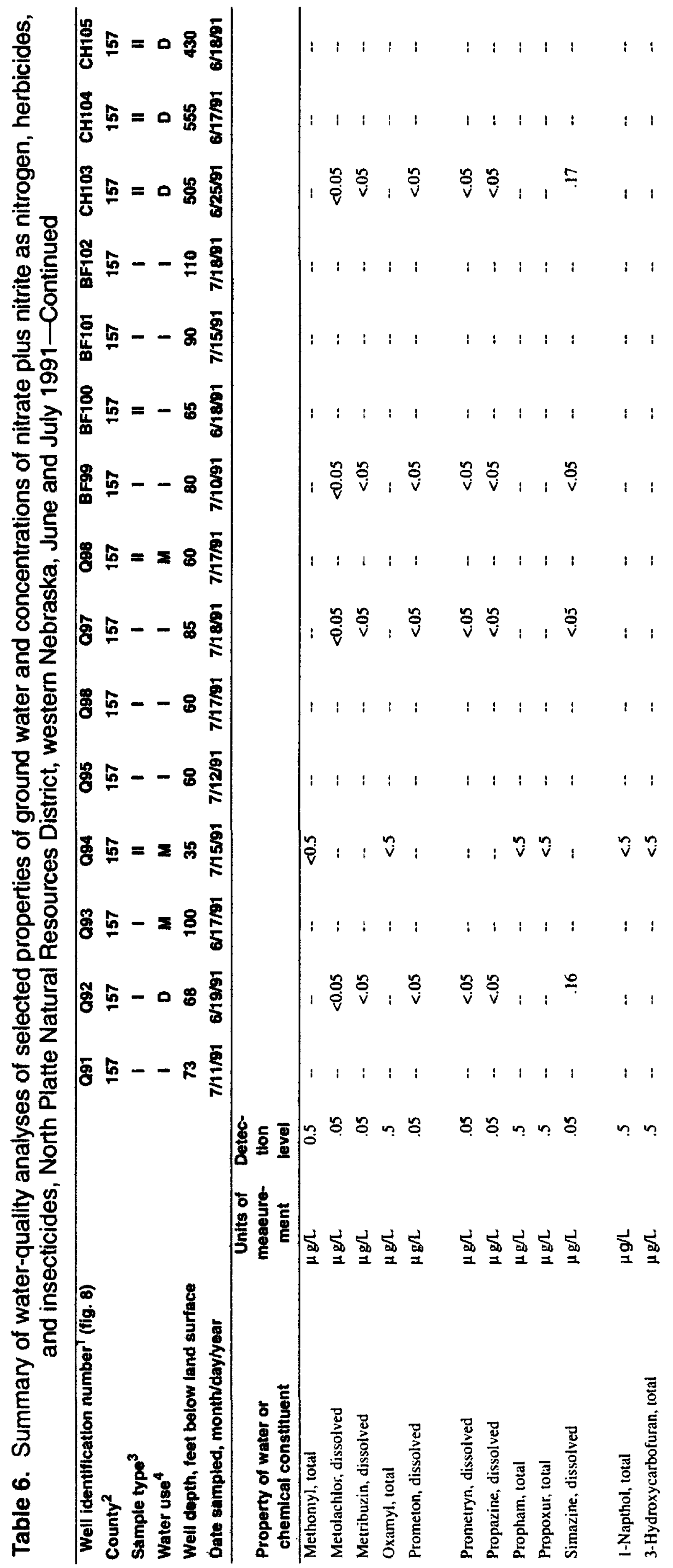




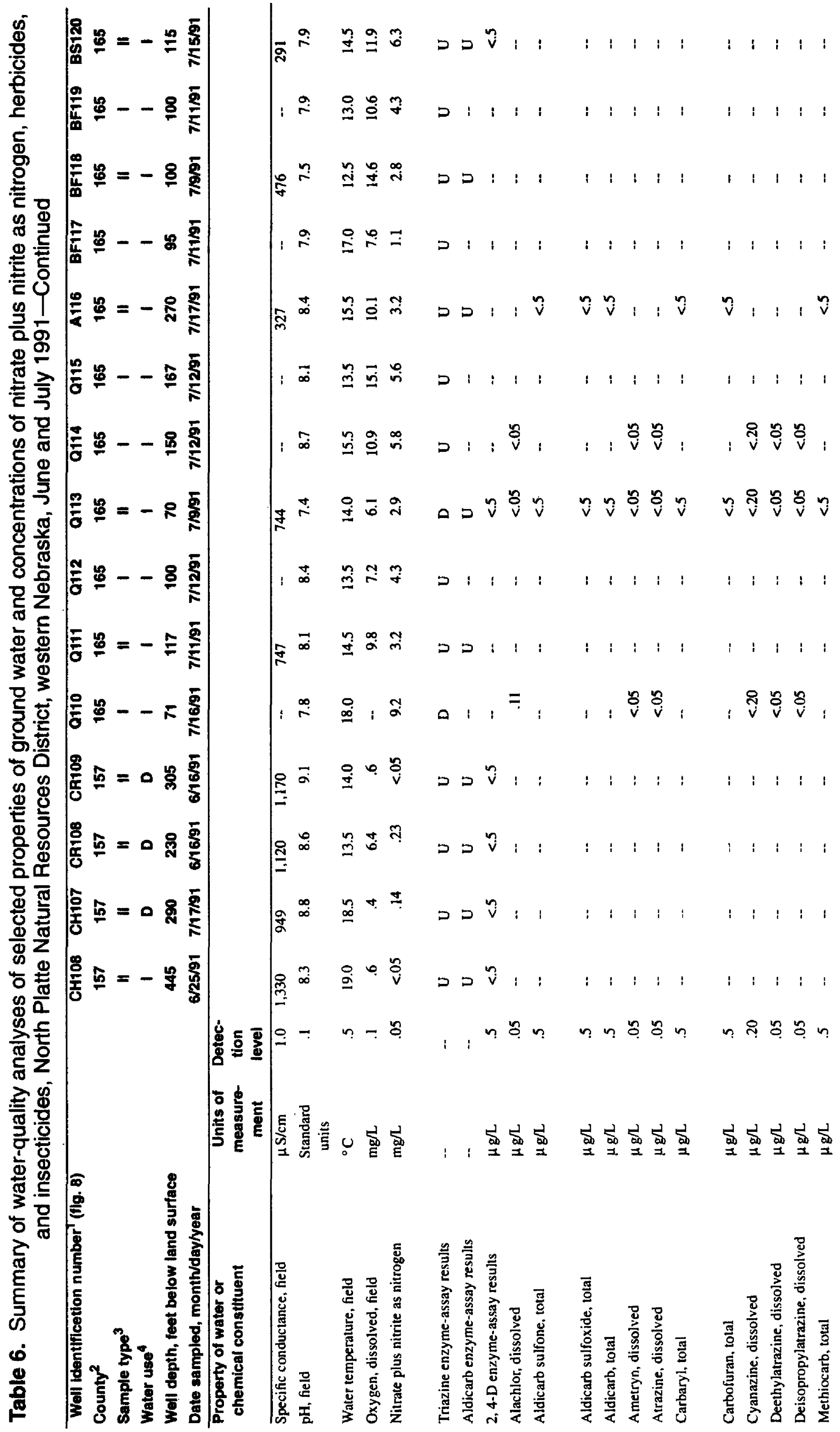




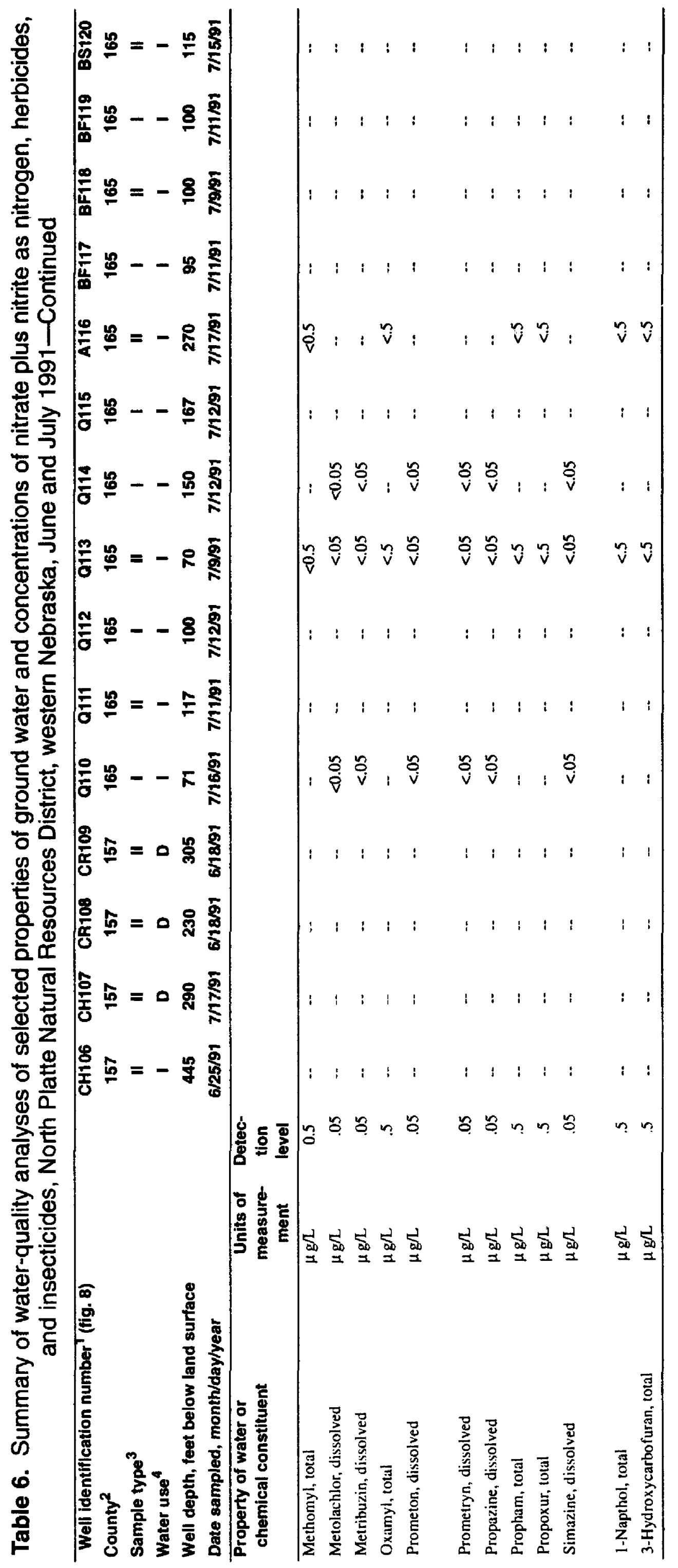




$$
\text { L. }
$$




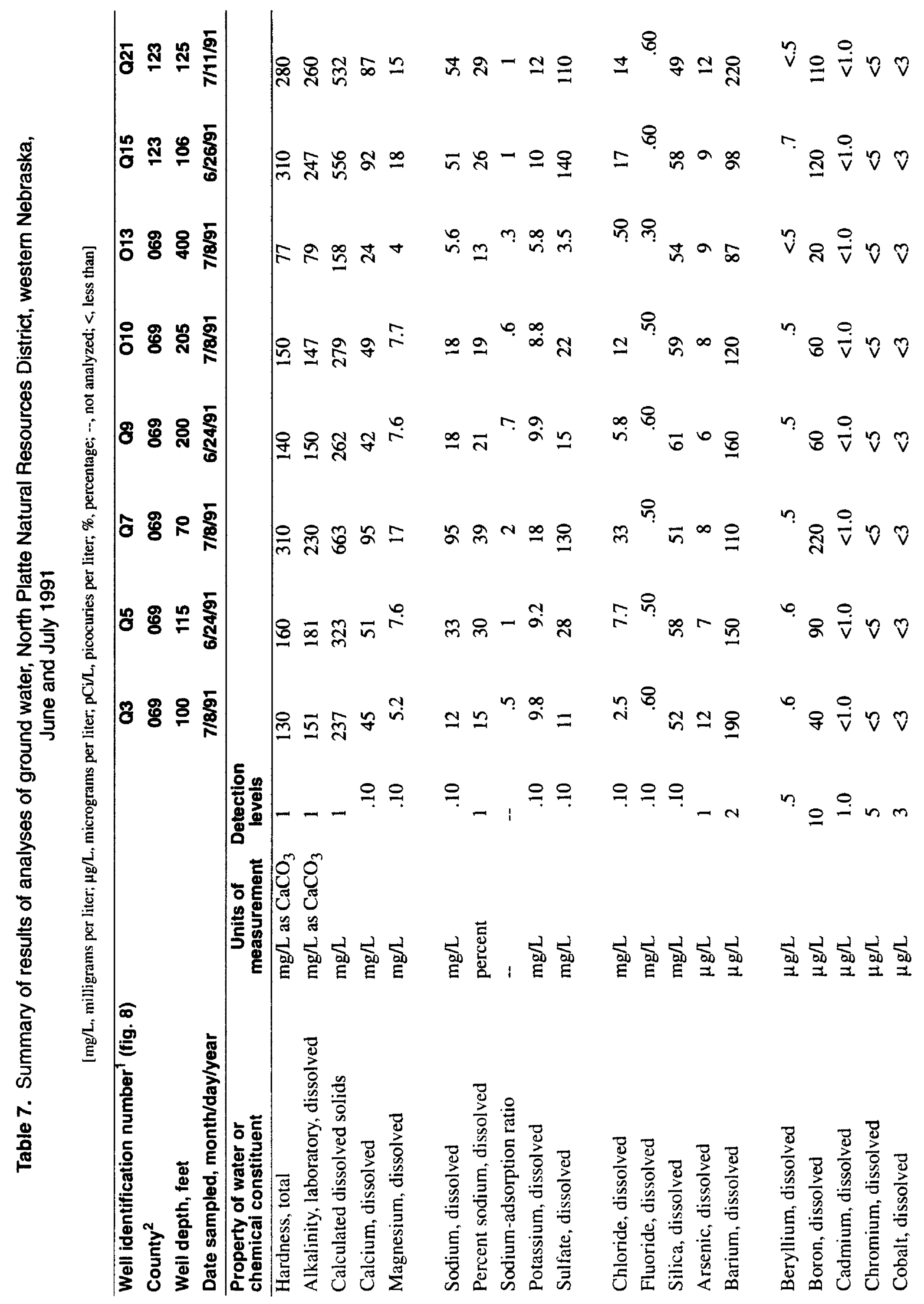




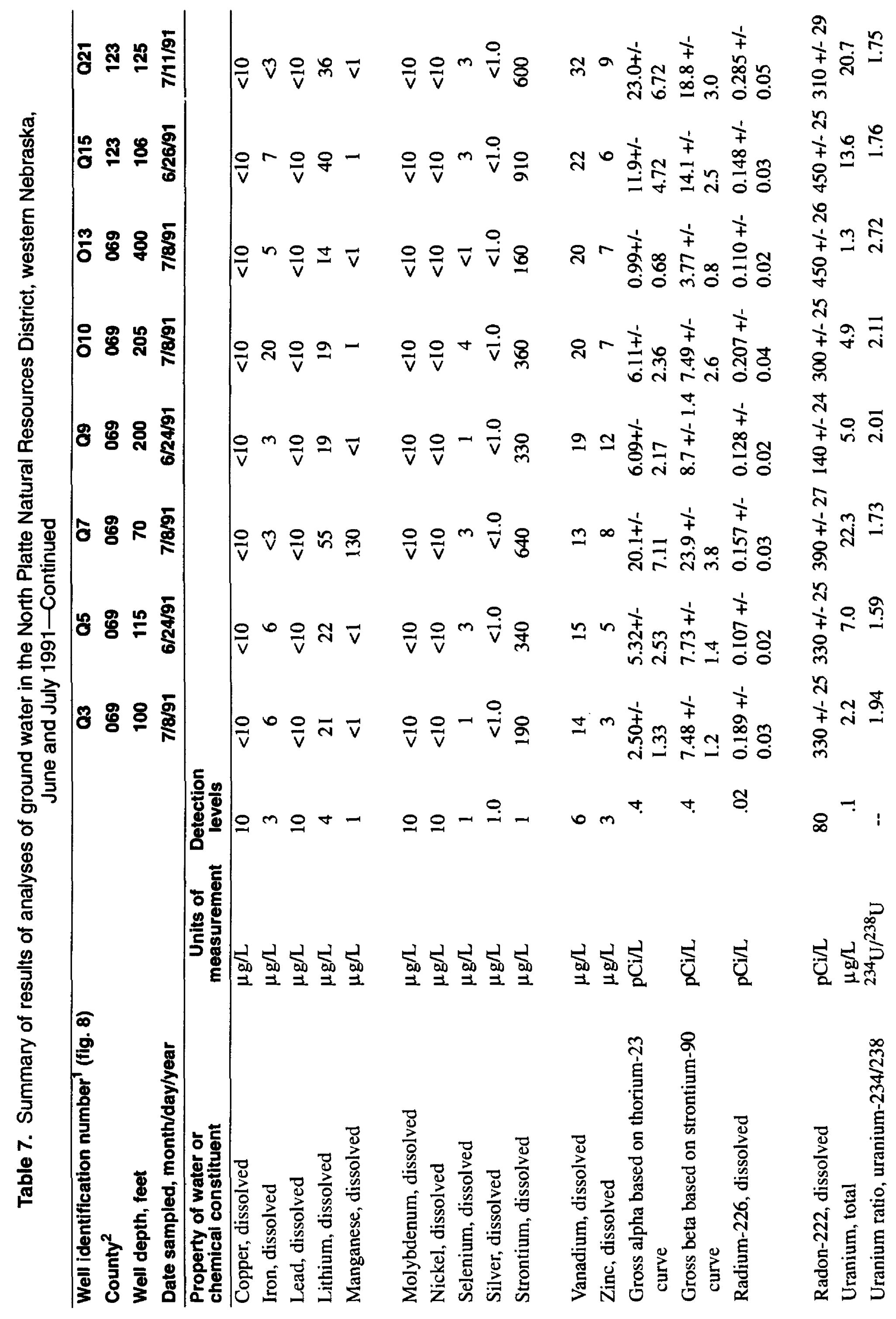




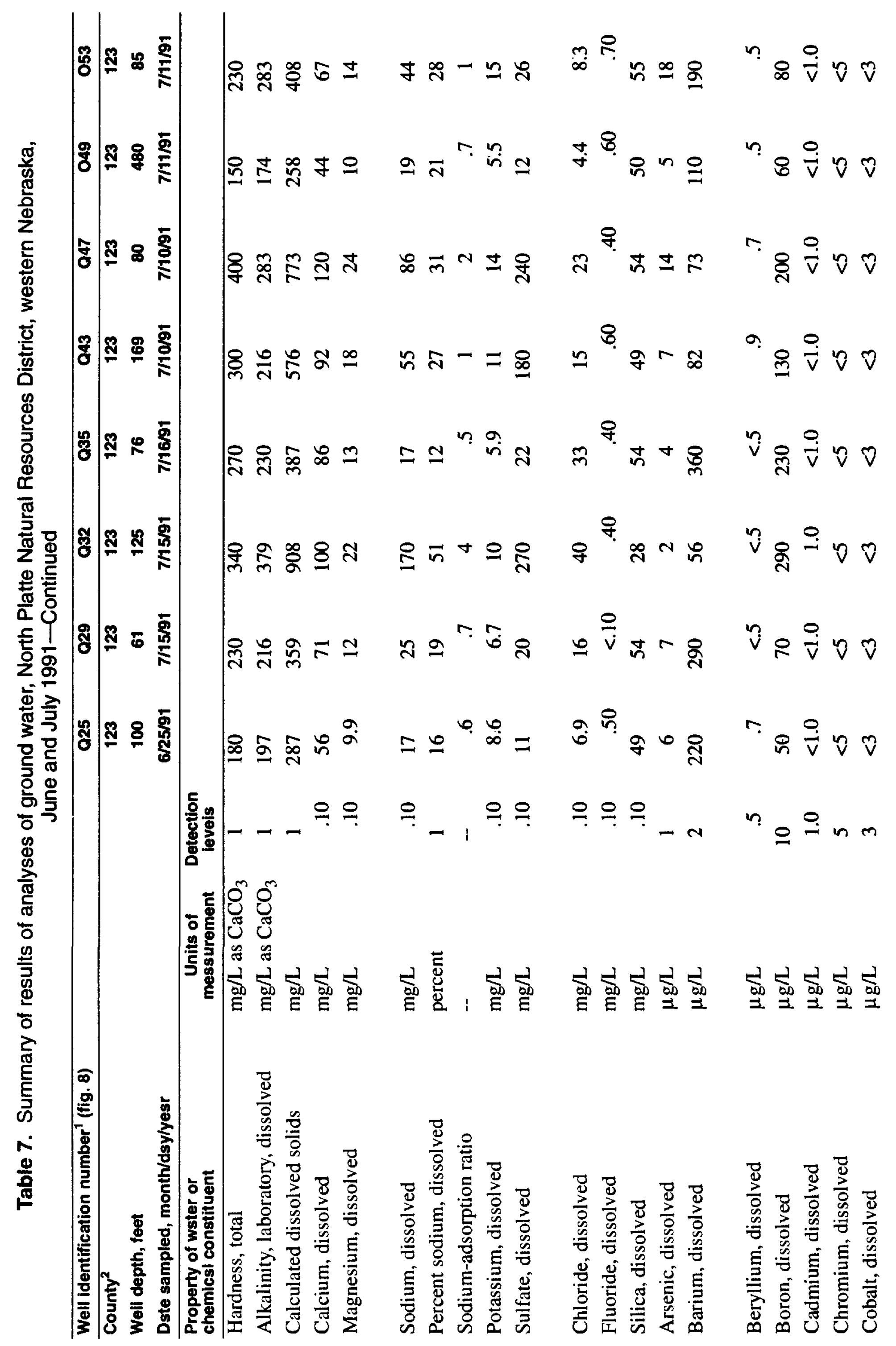

Summary of Reaults of Analysea of Ground Water, Weatern Nebraeka, June and July 199175 


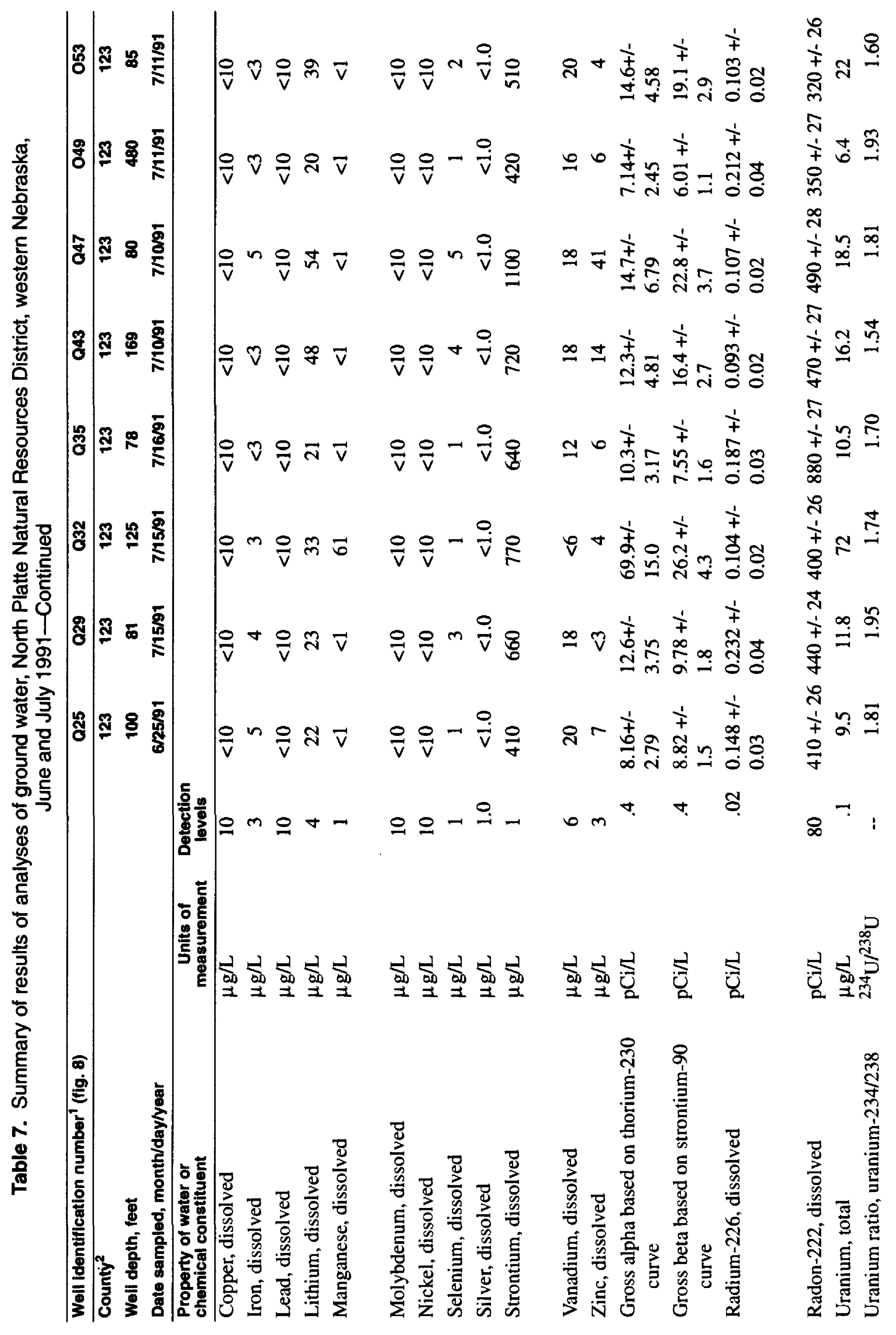




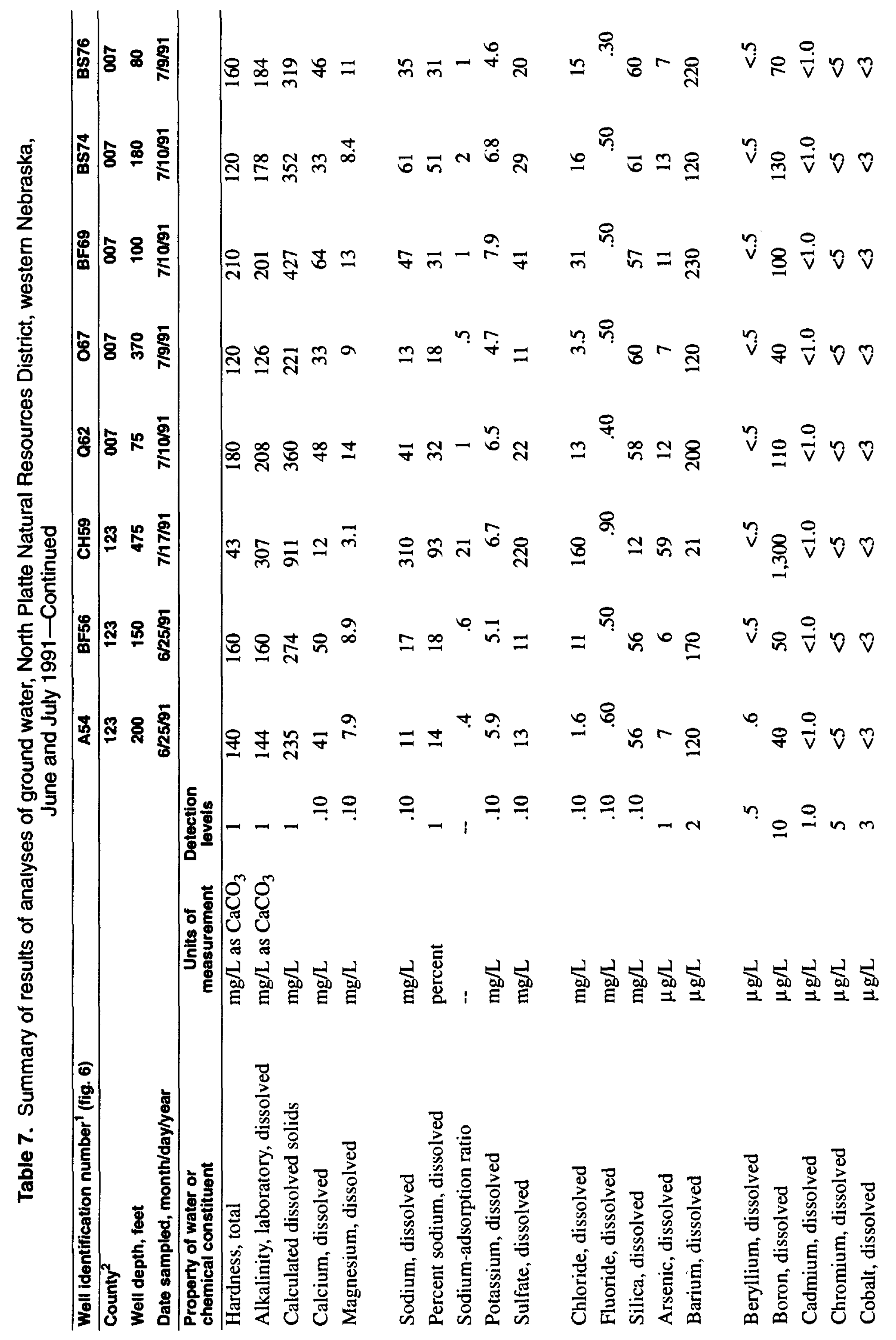




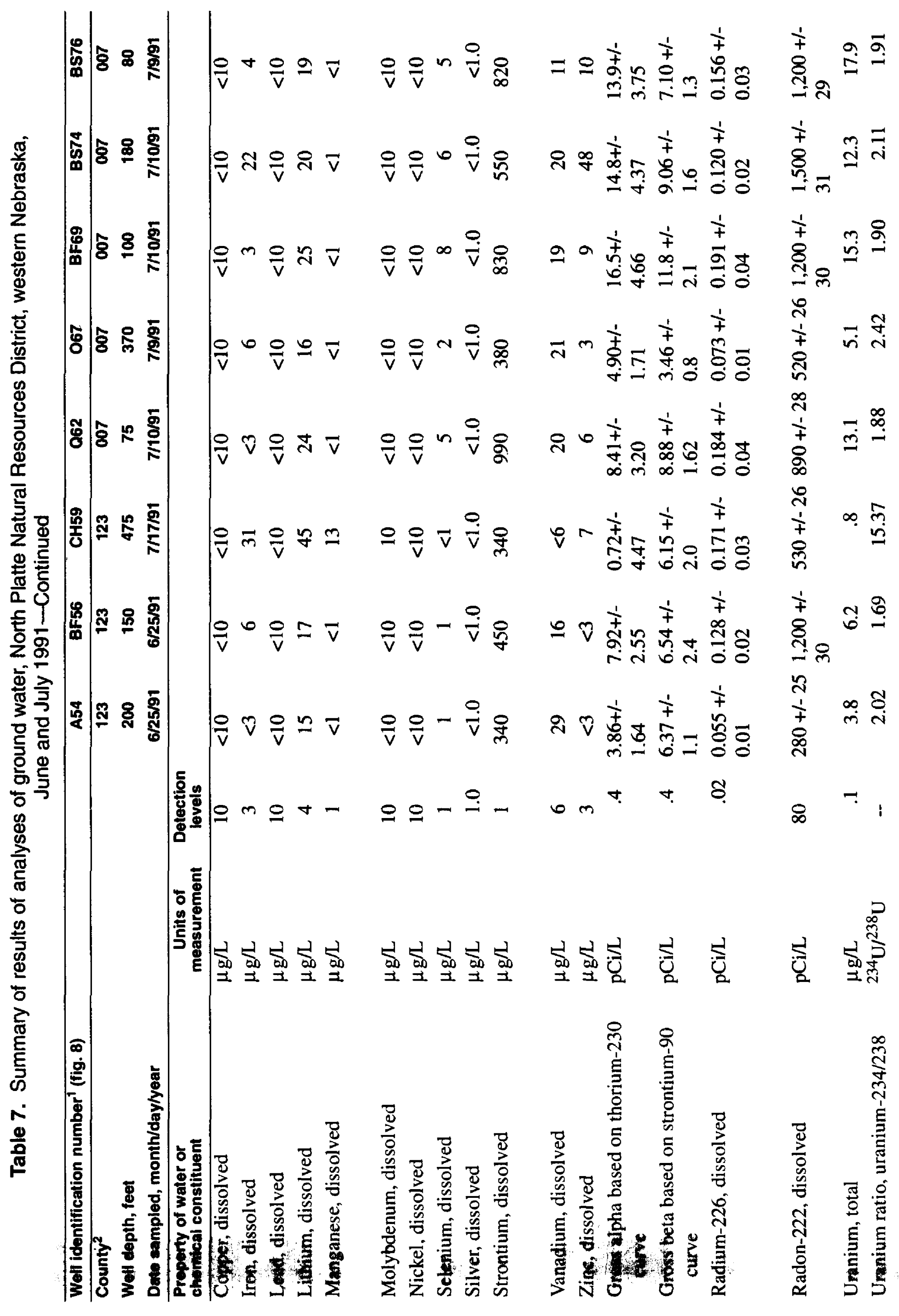




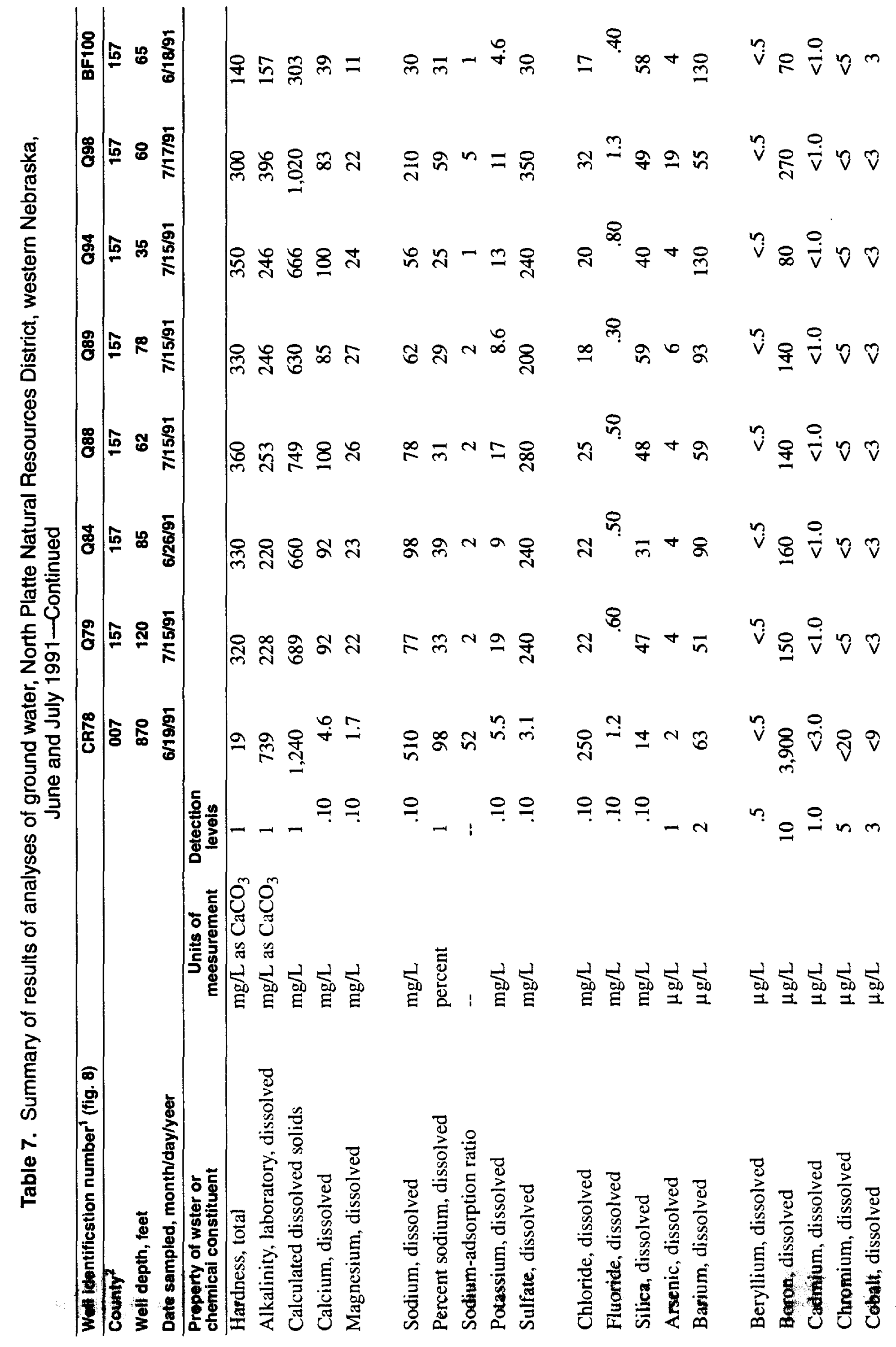




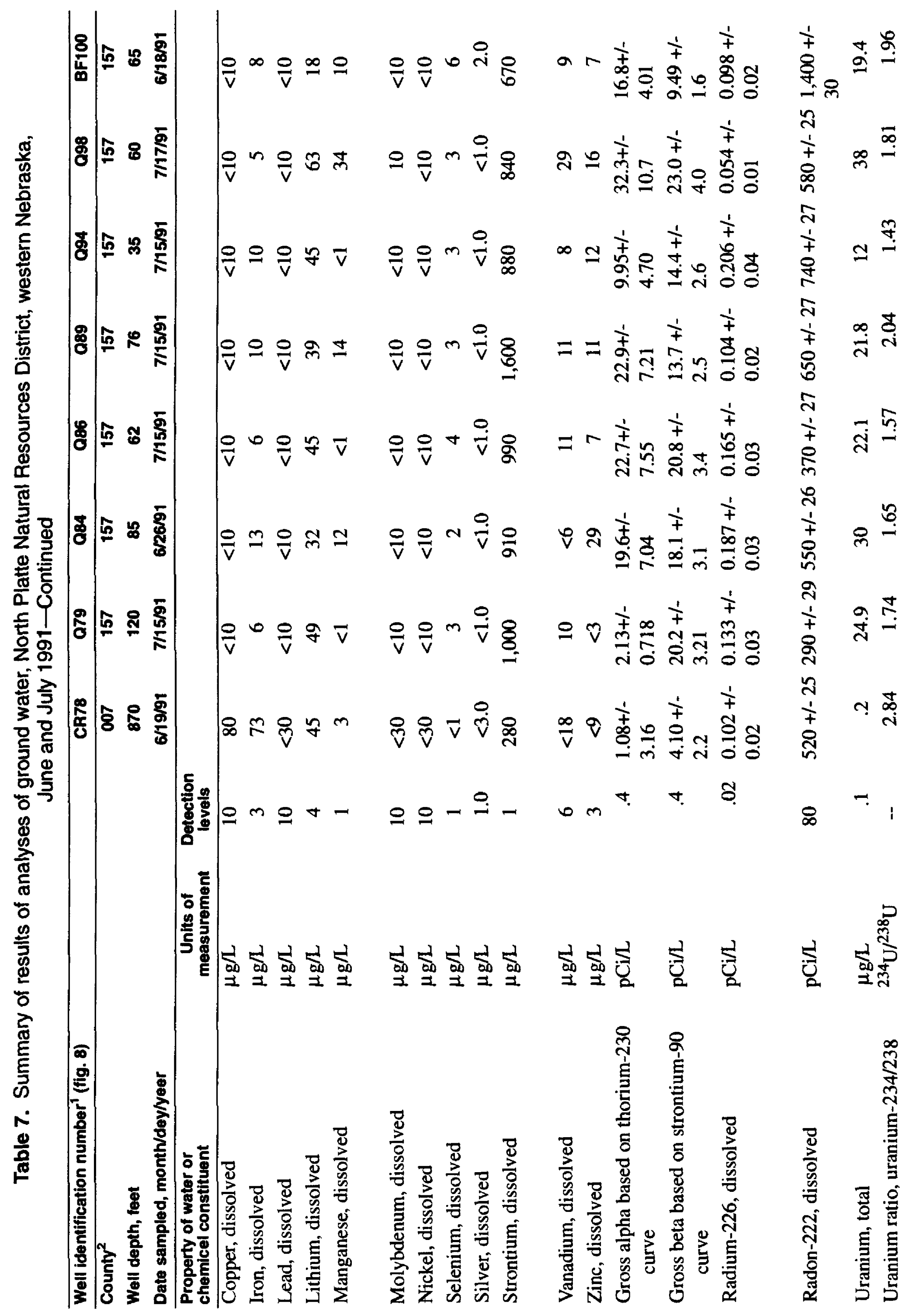




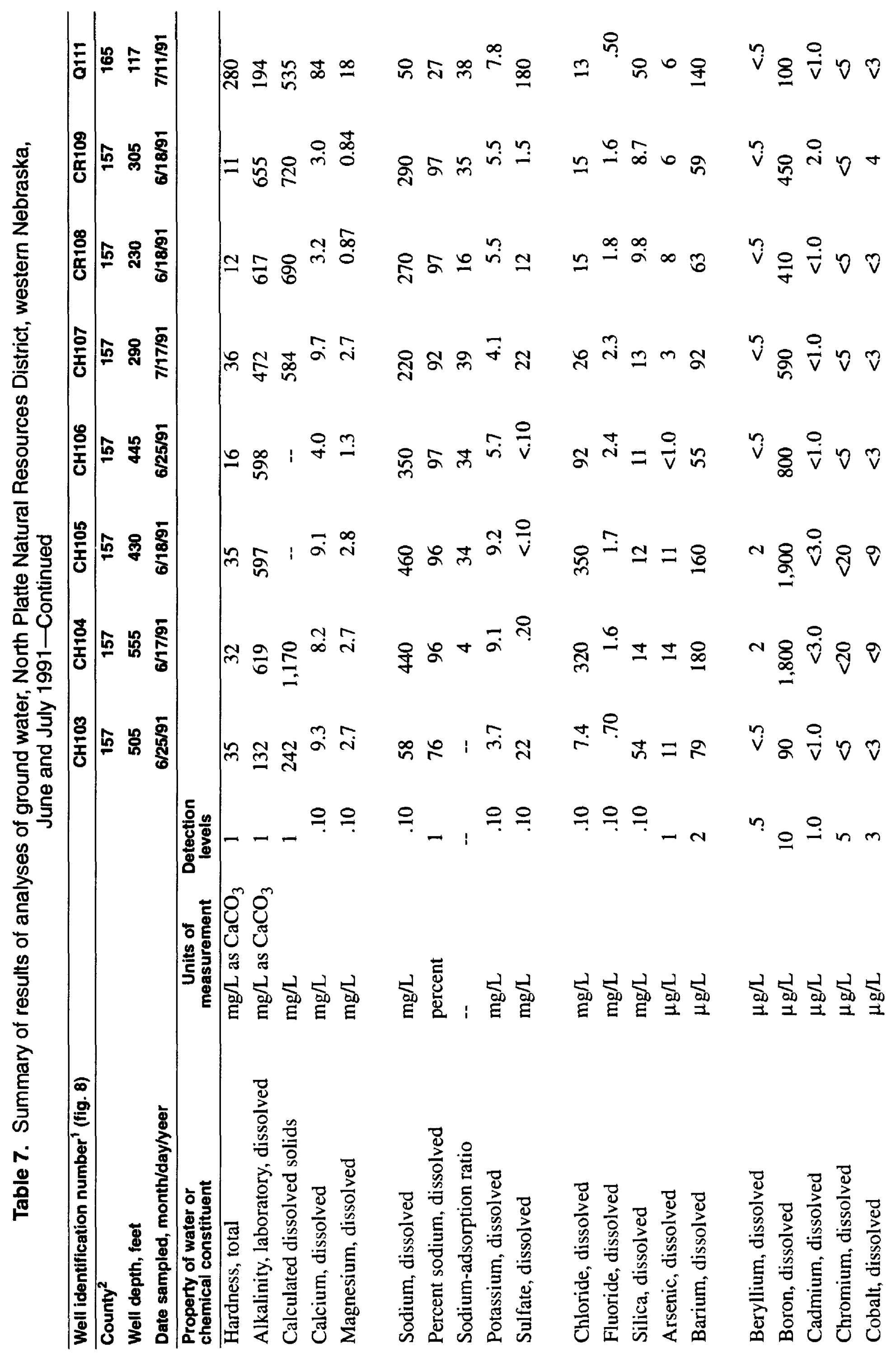

Summary of Results of Analyses of Ground Water, Western Nebraska, June and July 199181 


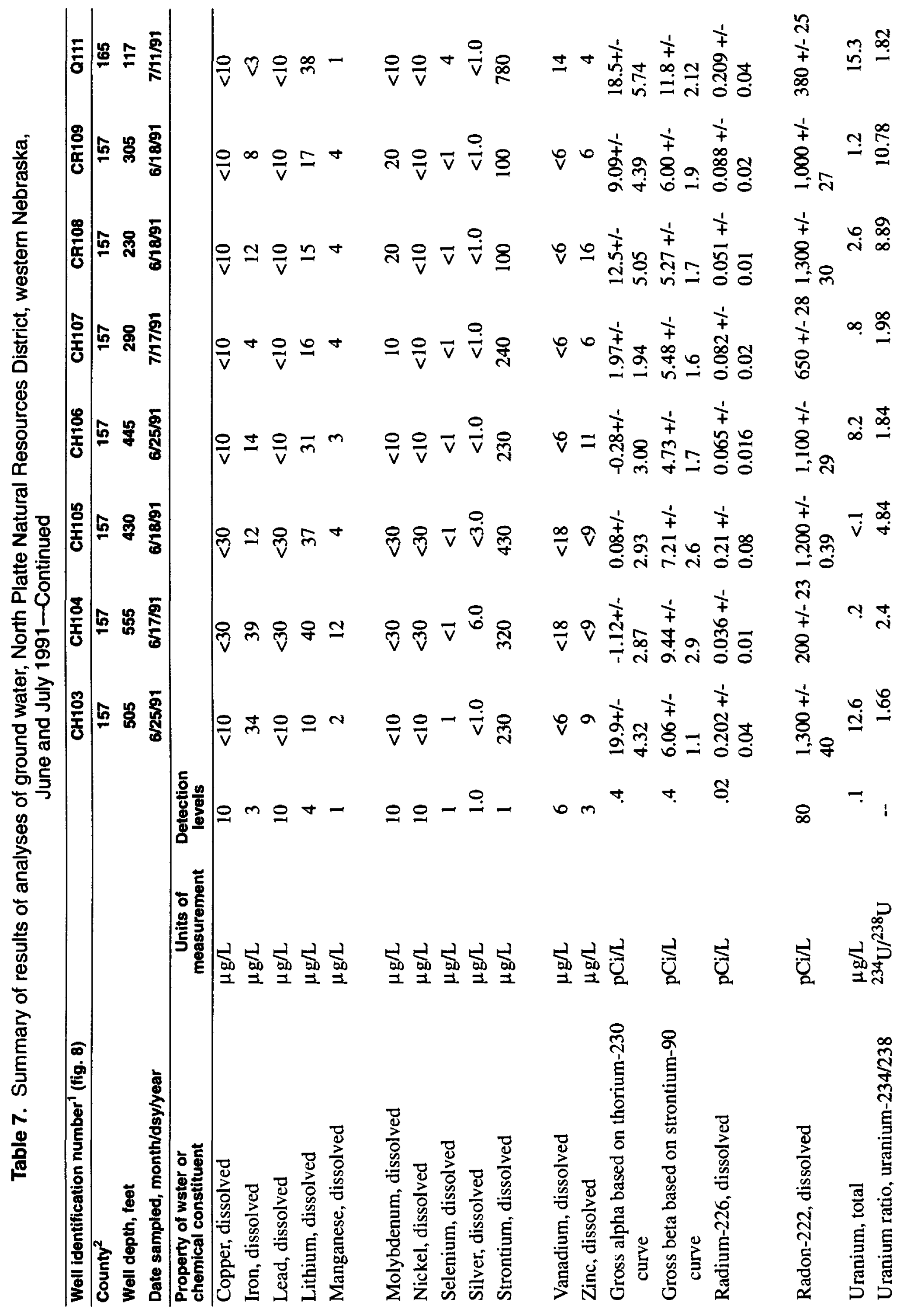




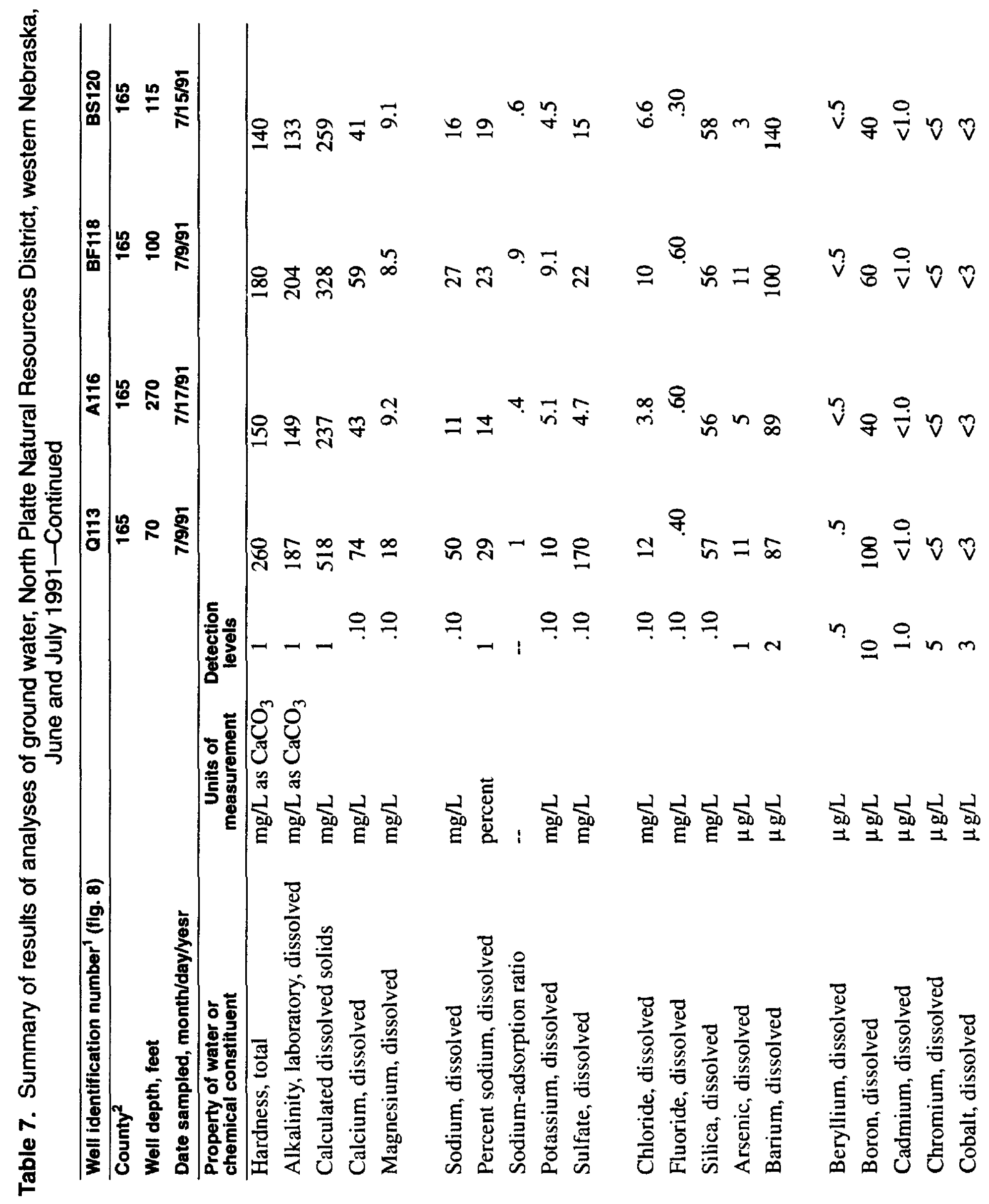




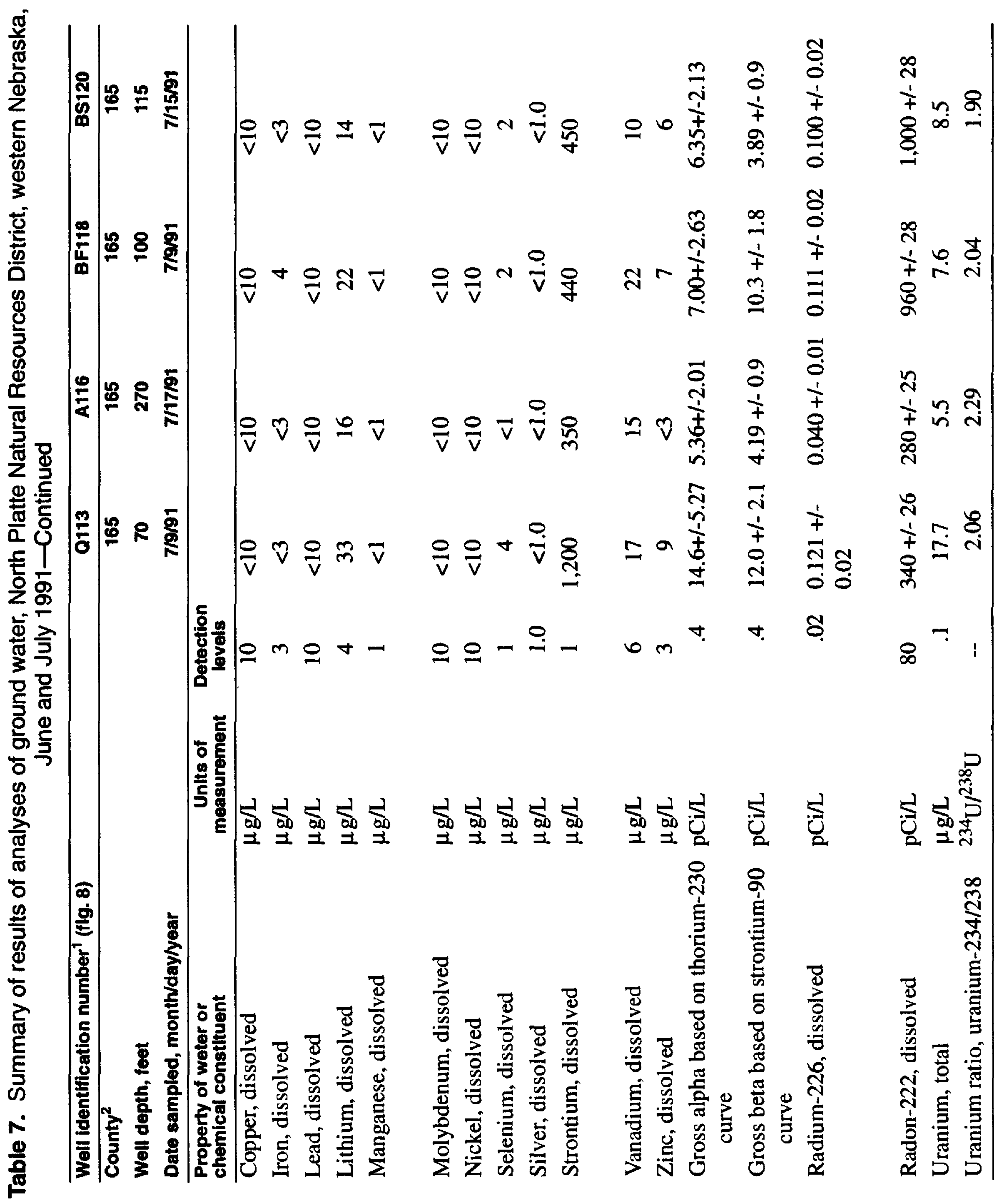




$$
L_{H}
$$




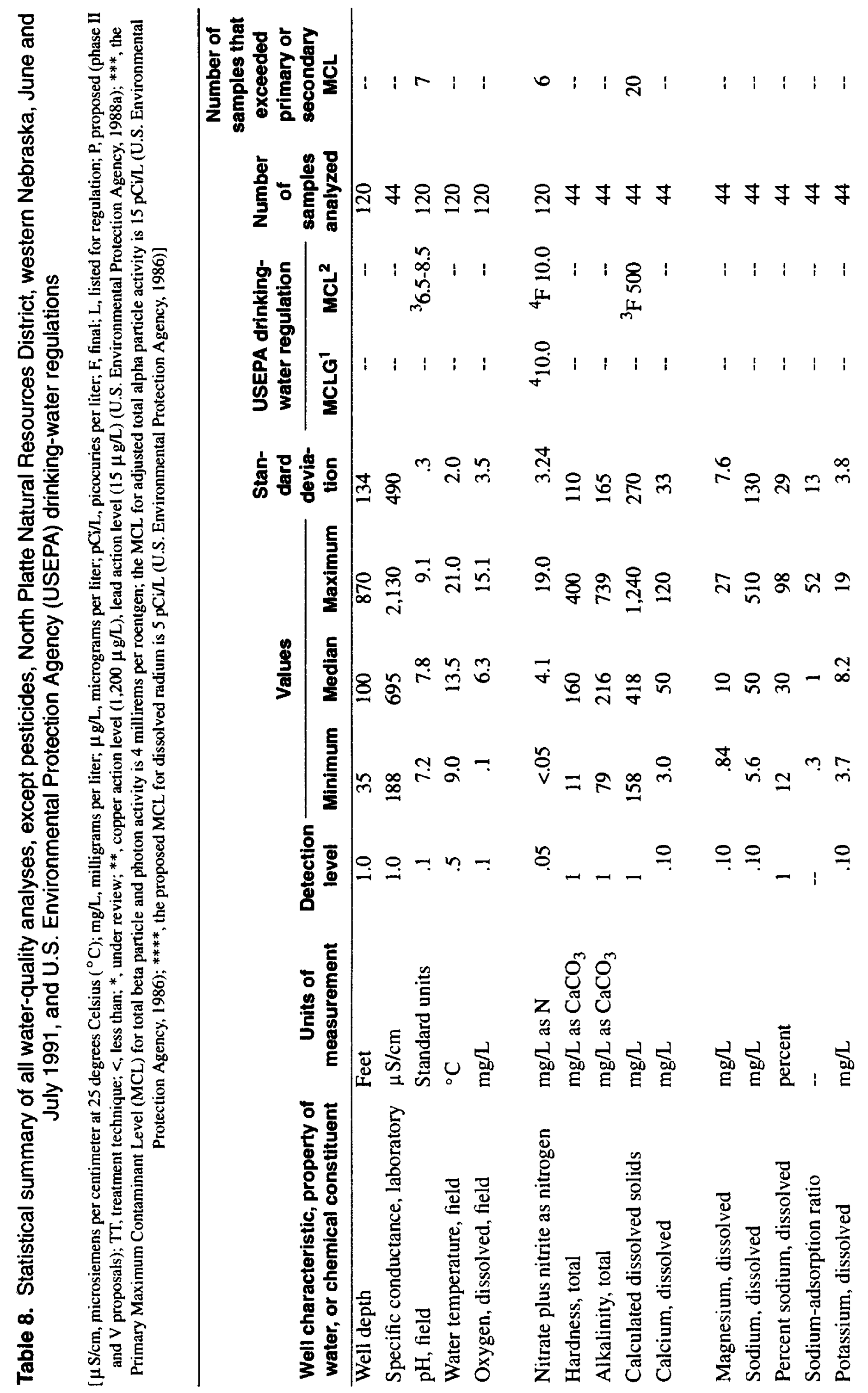




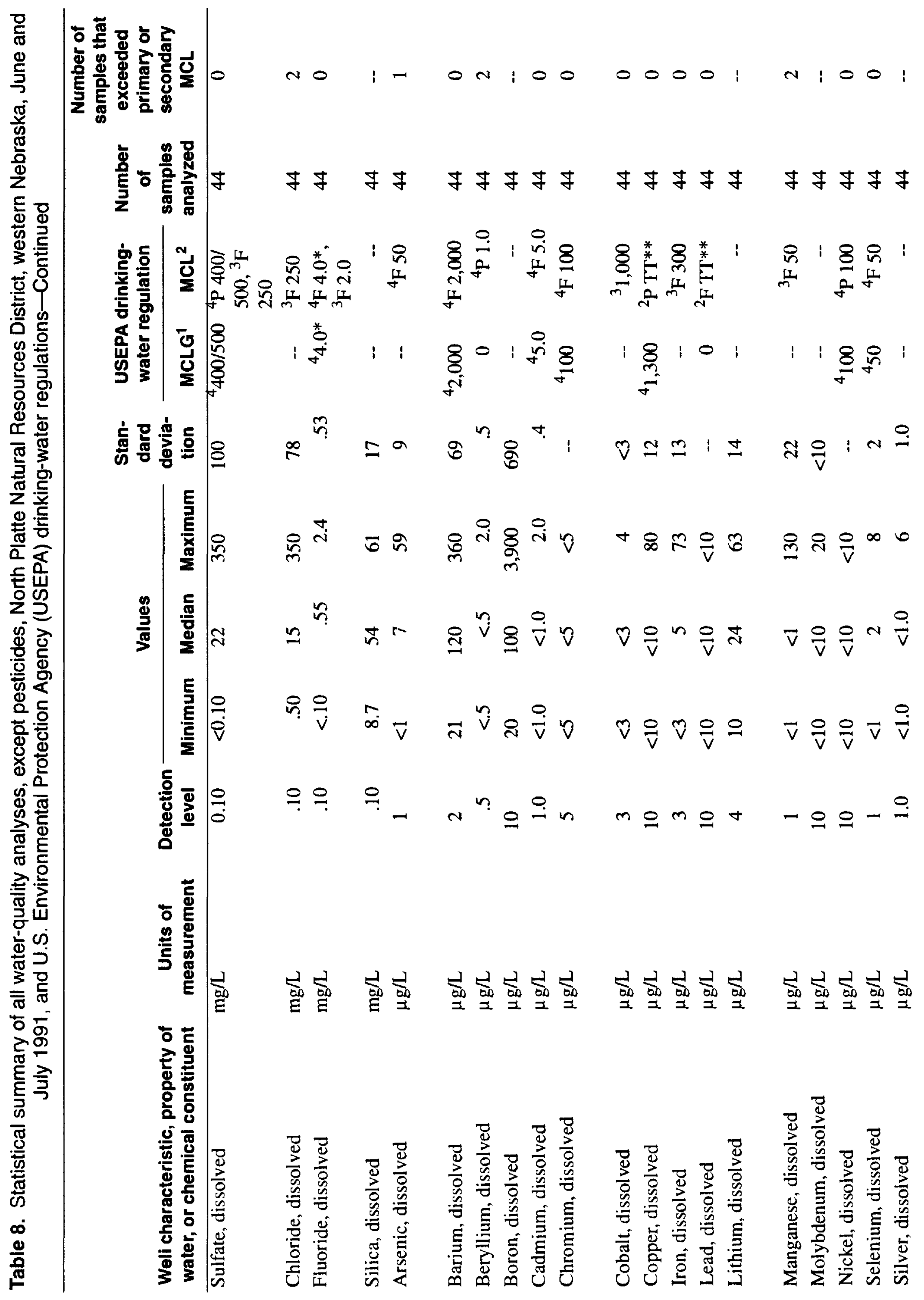




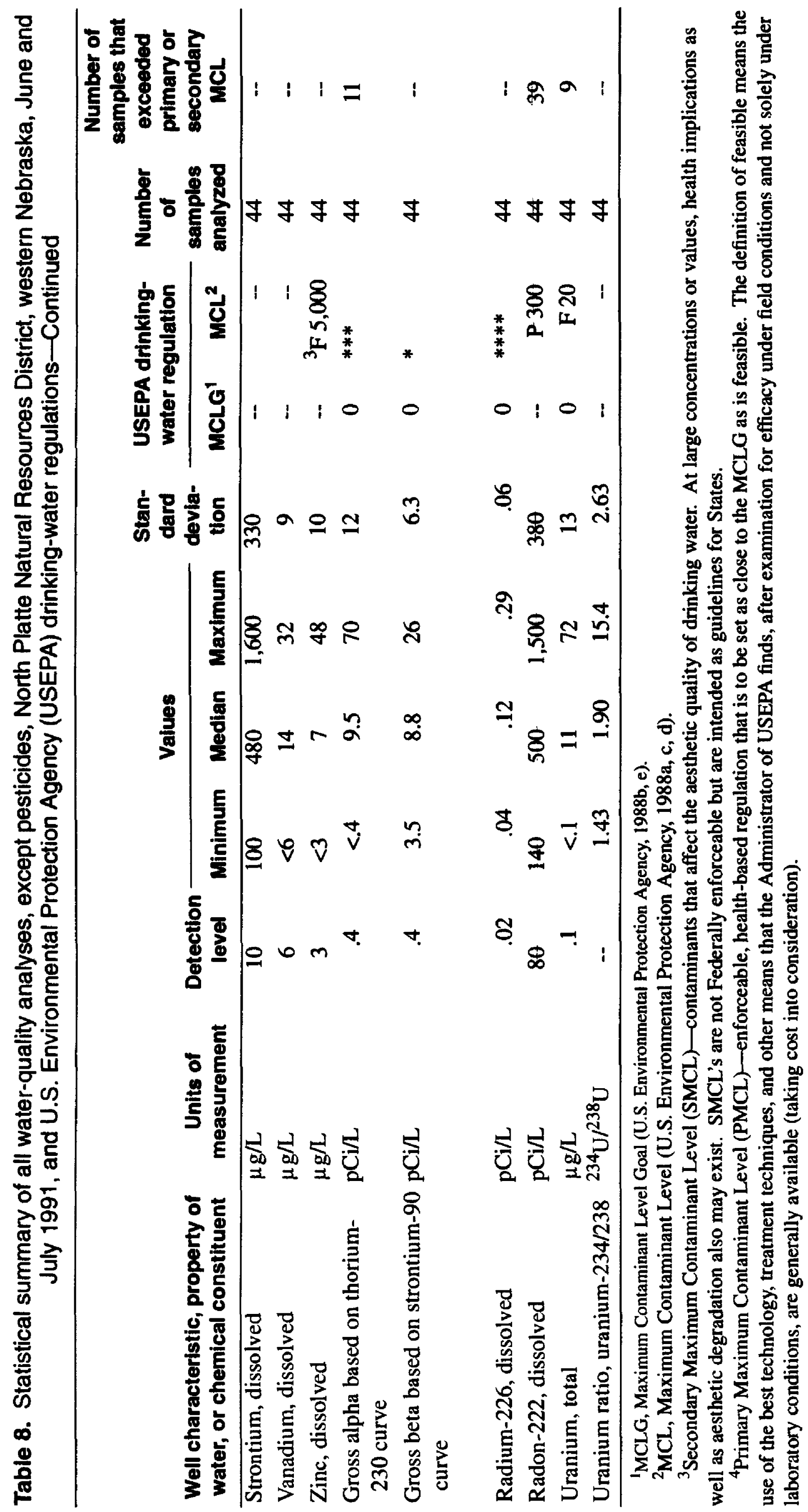




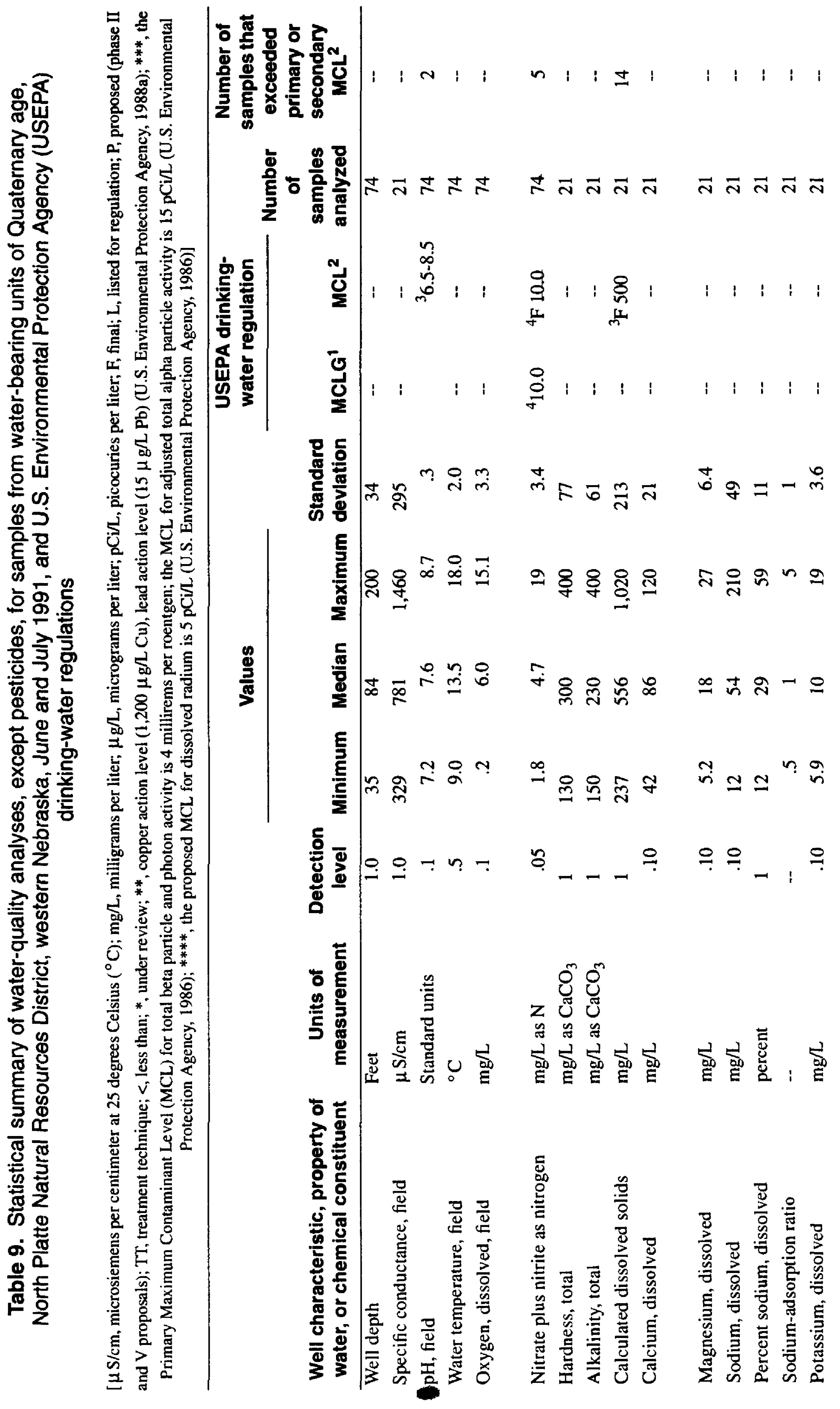




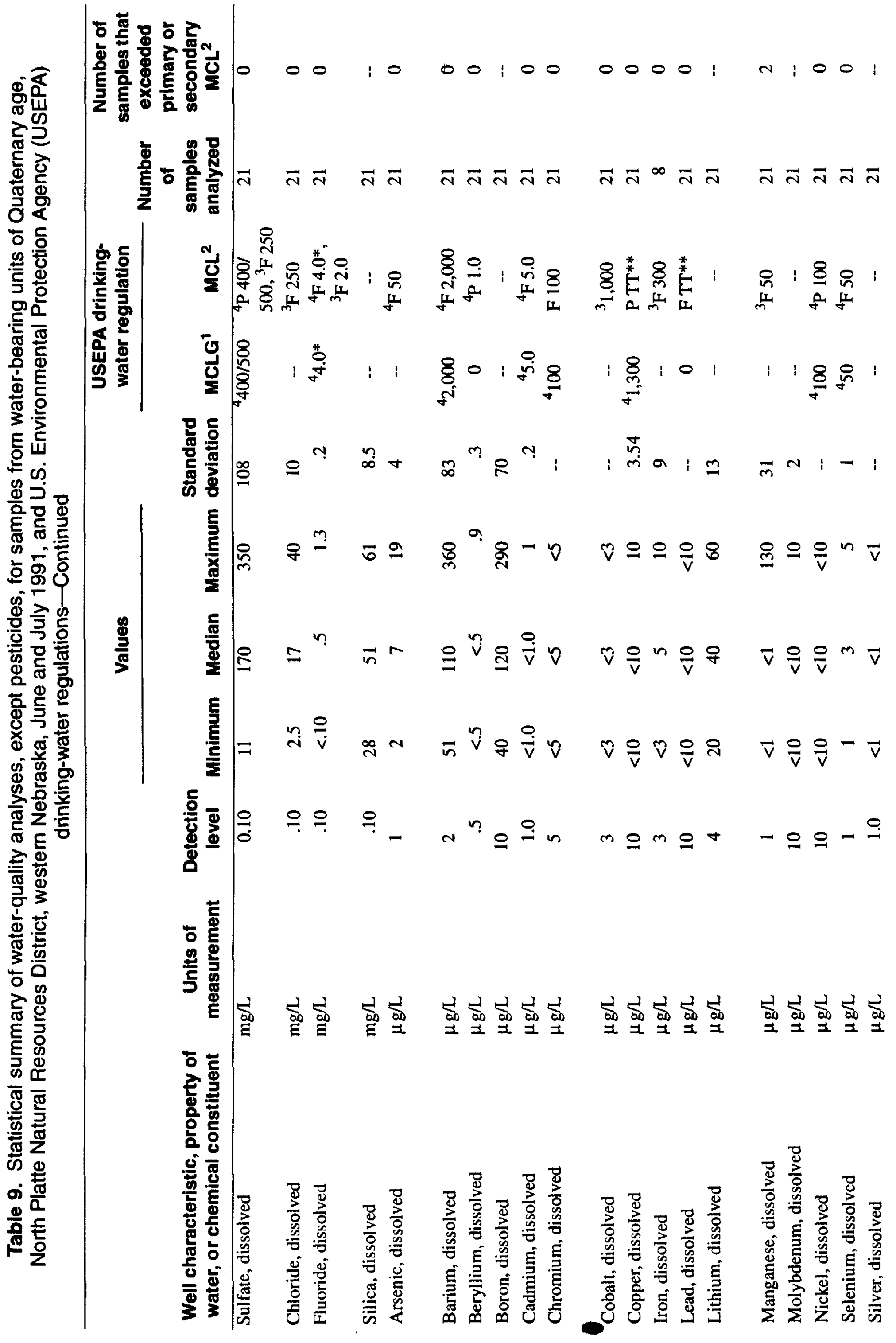




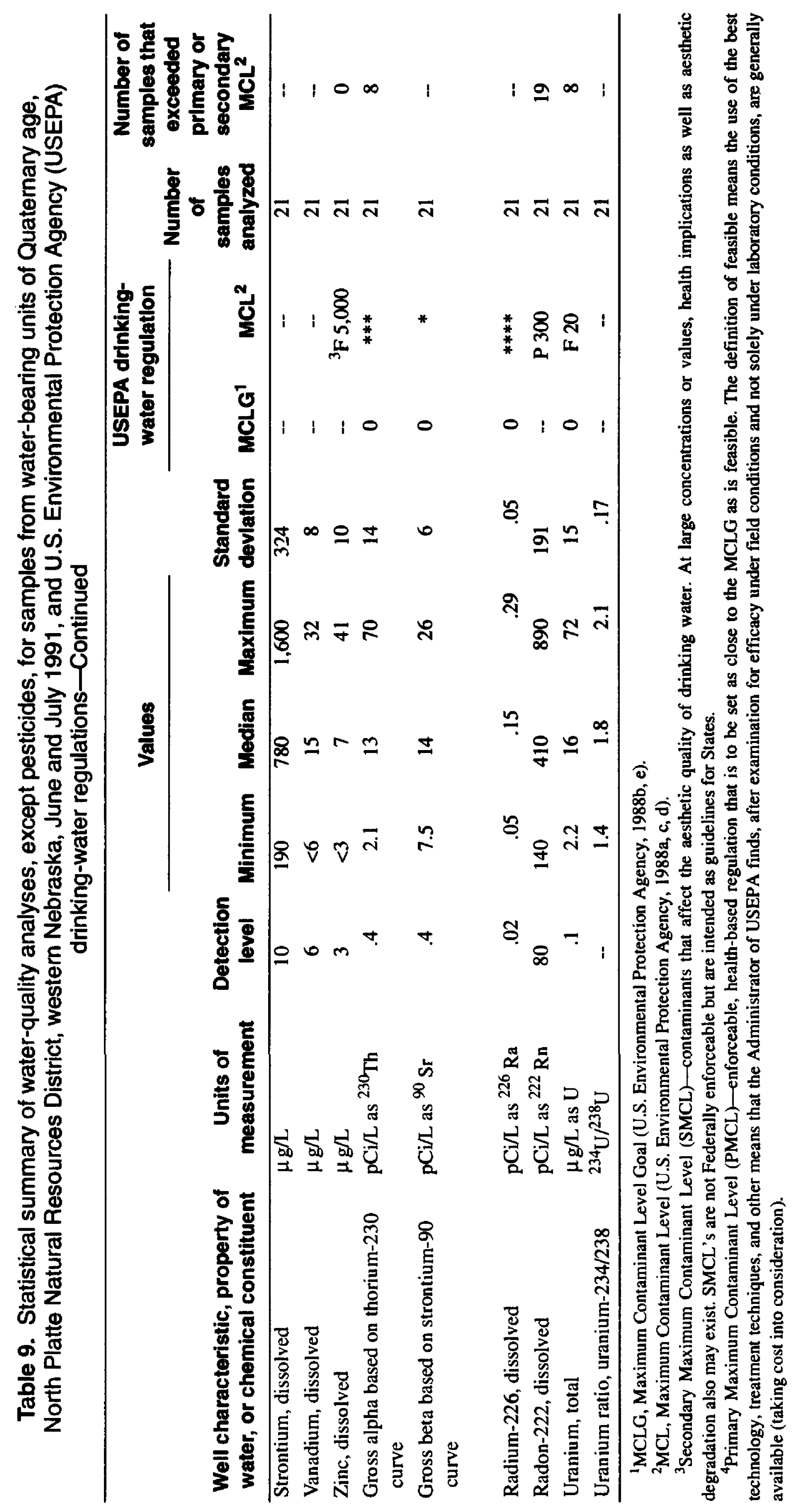




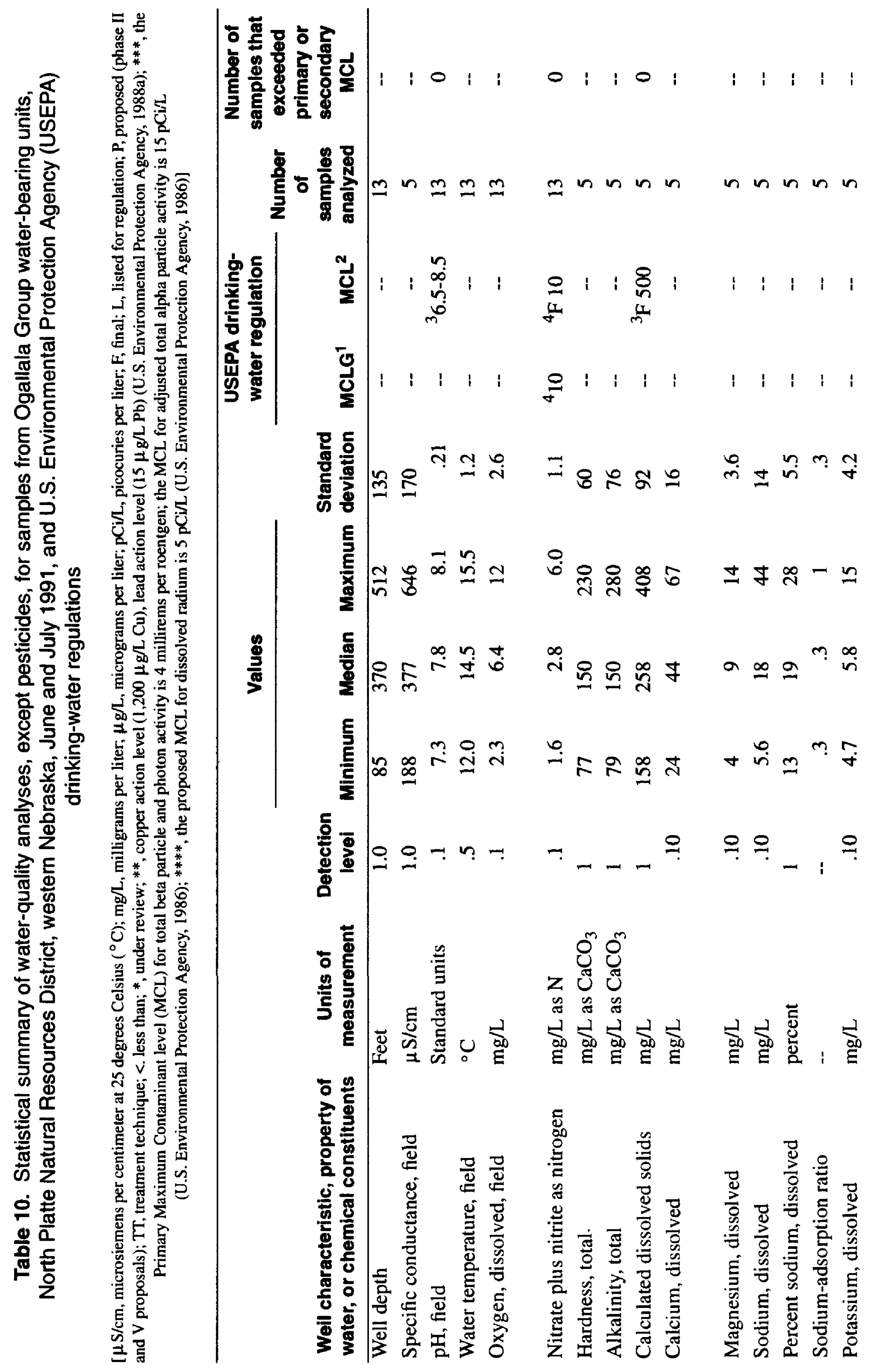




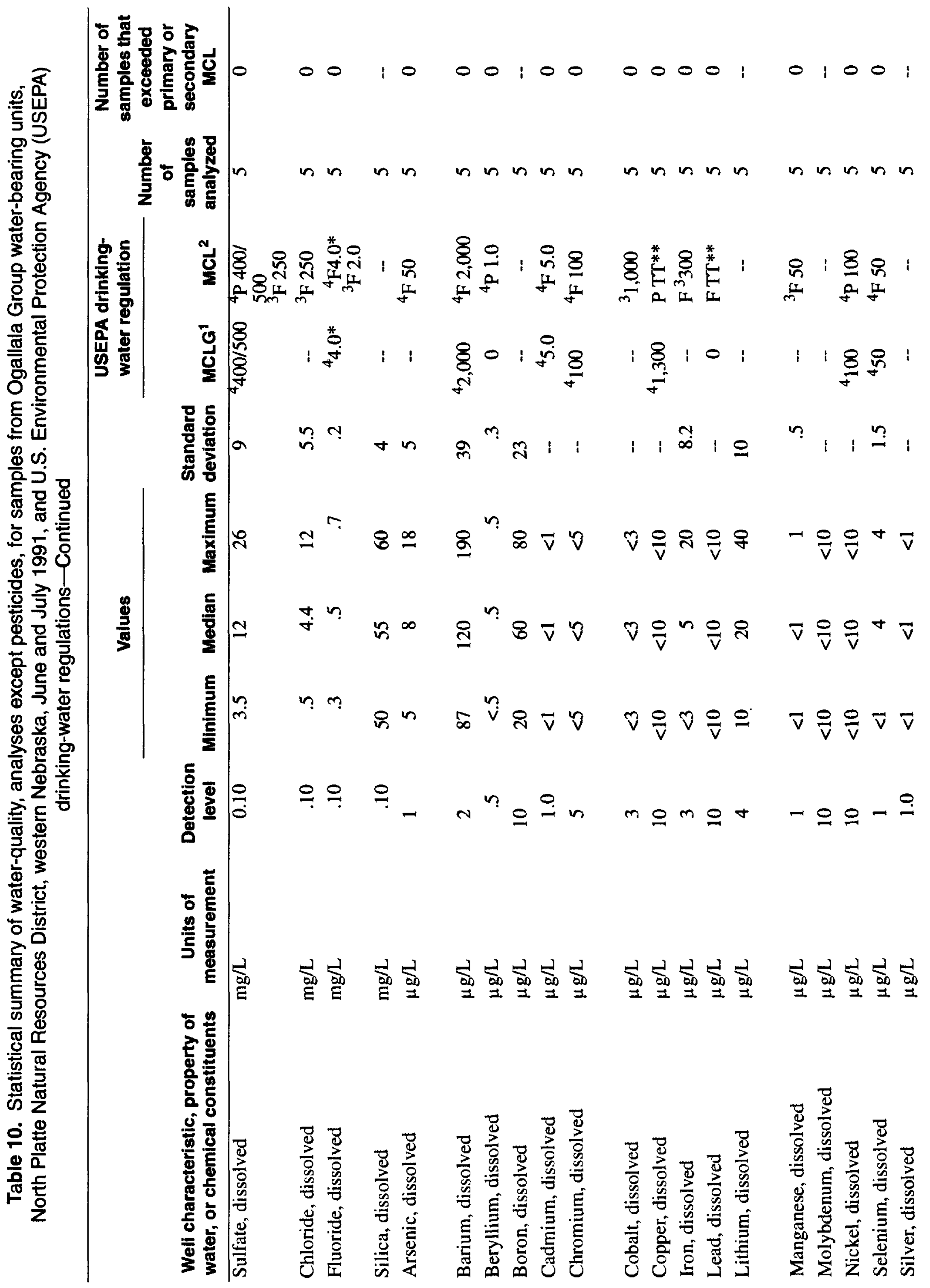




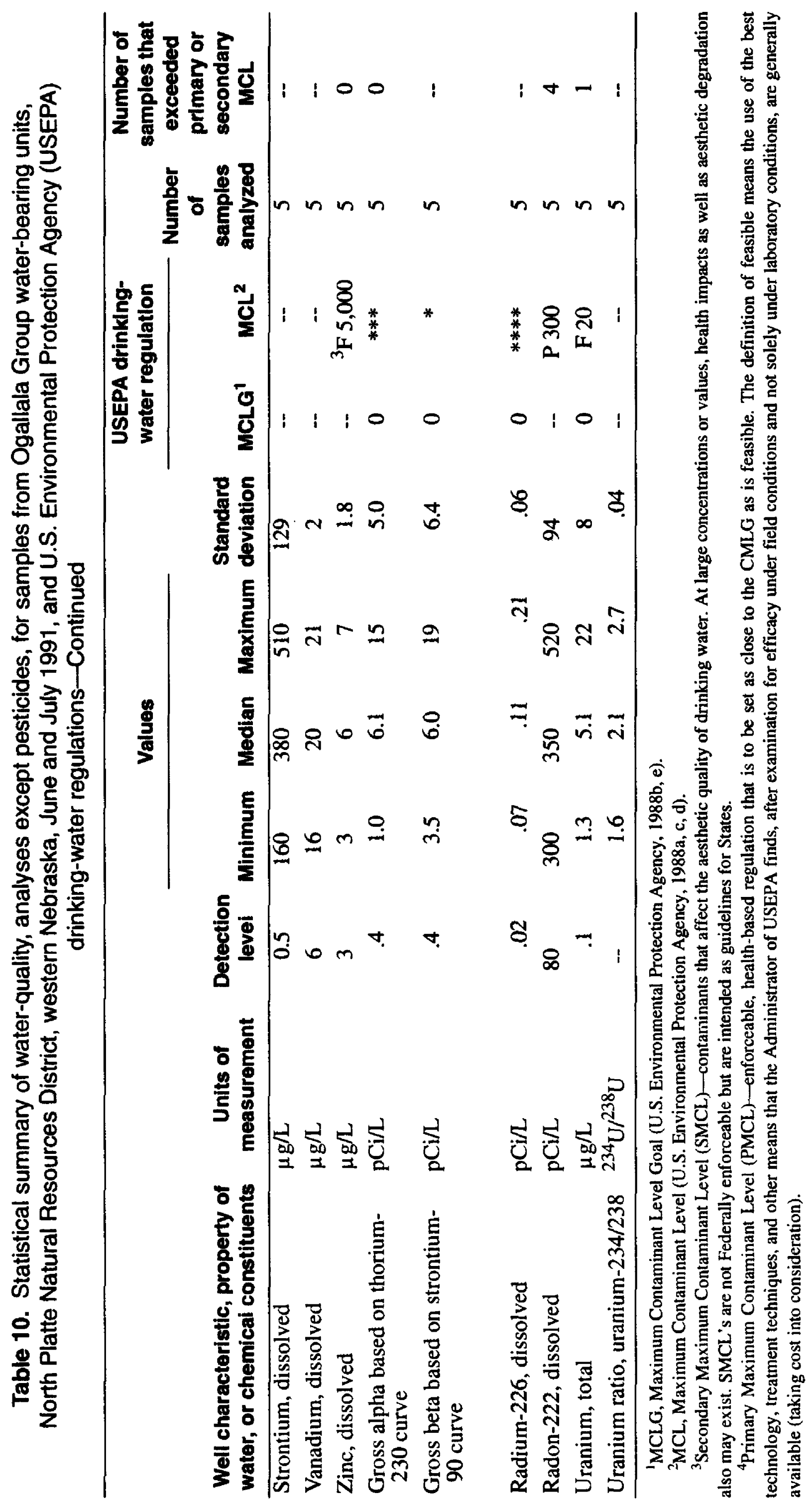




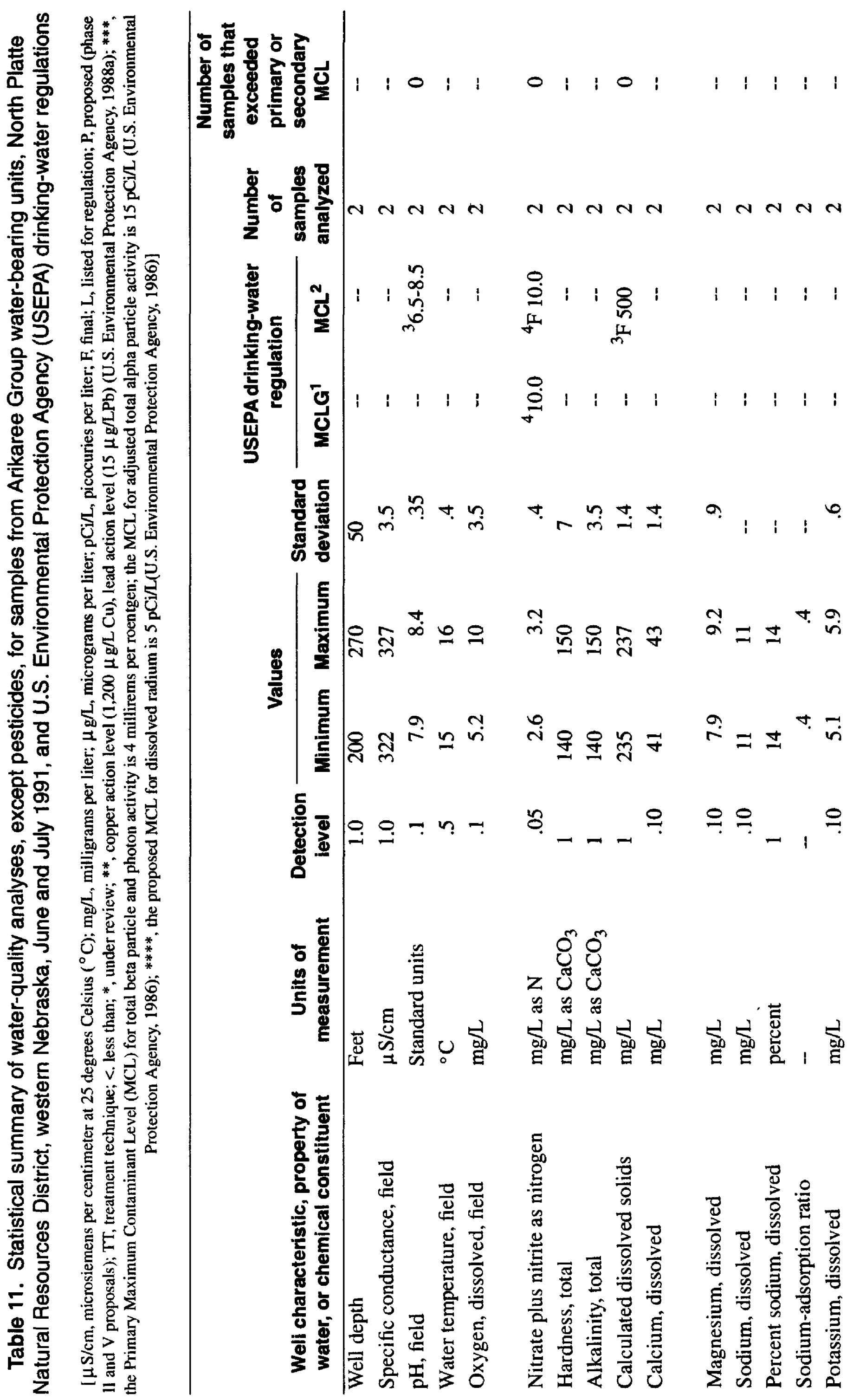




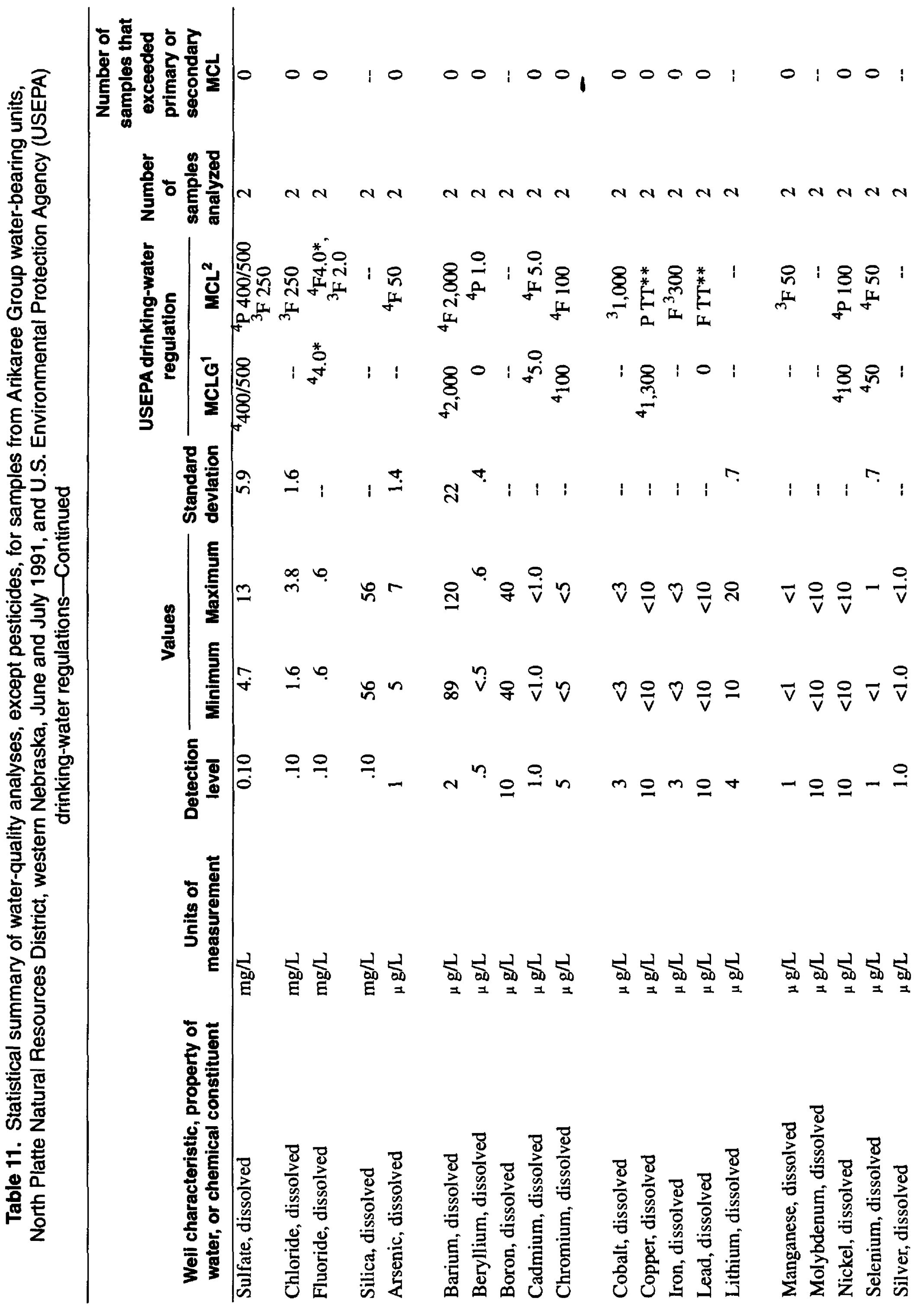




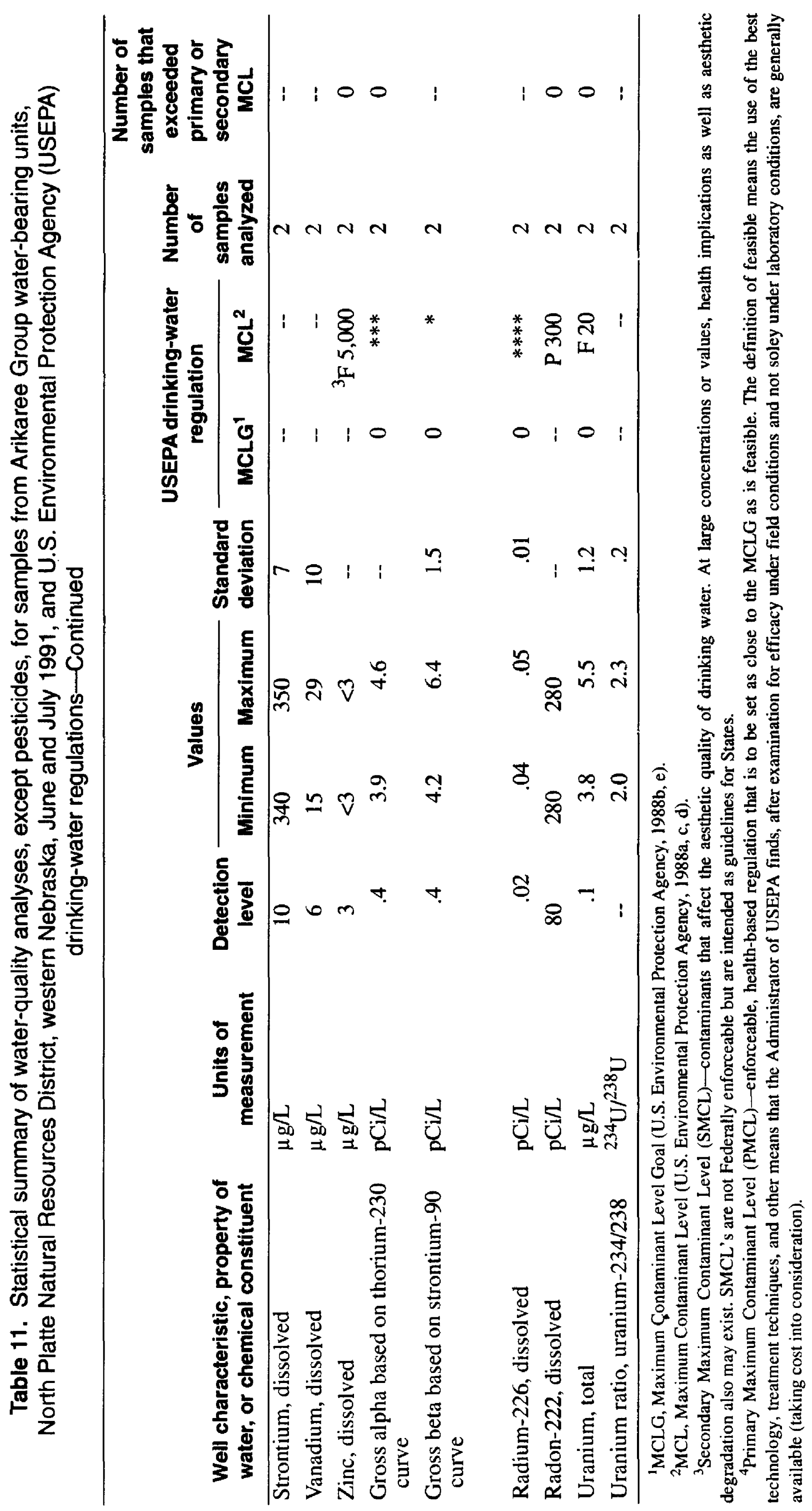




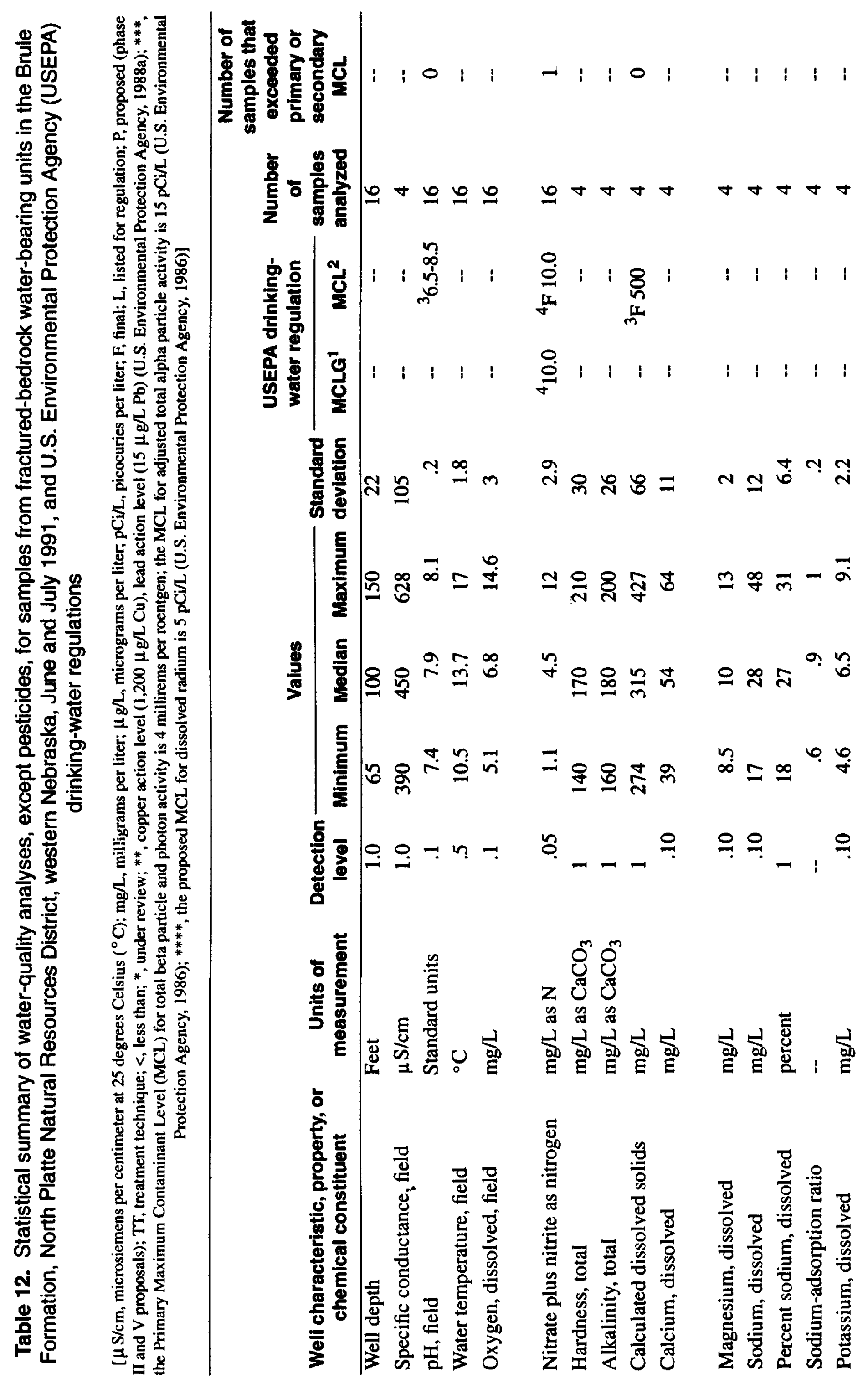




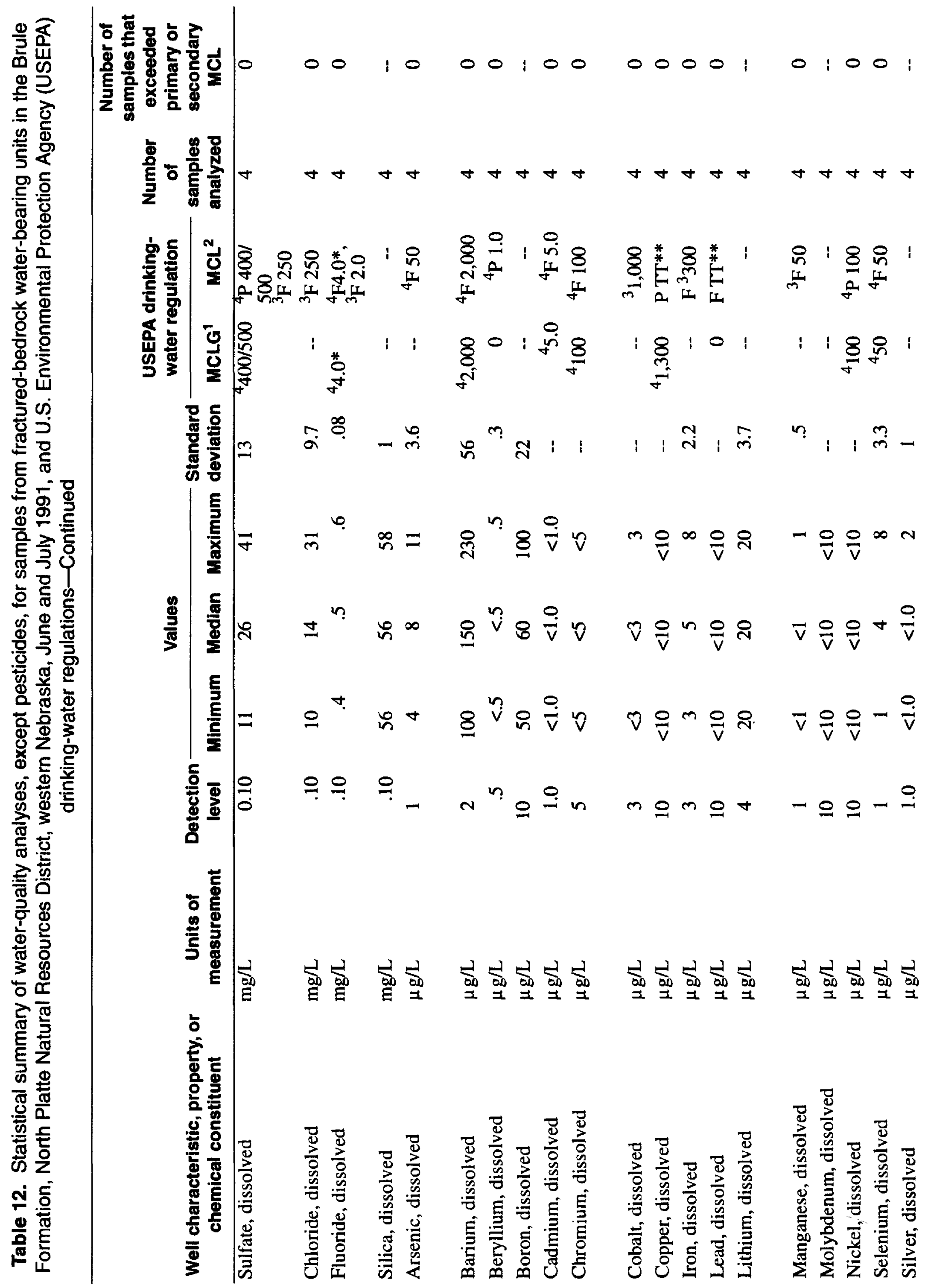




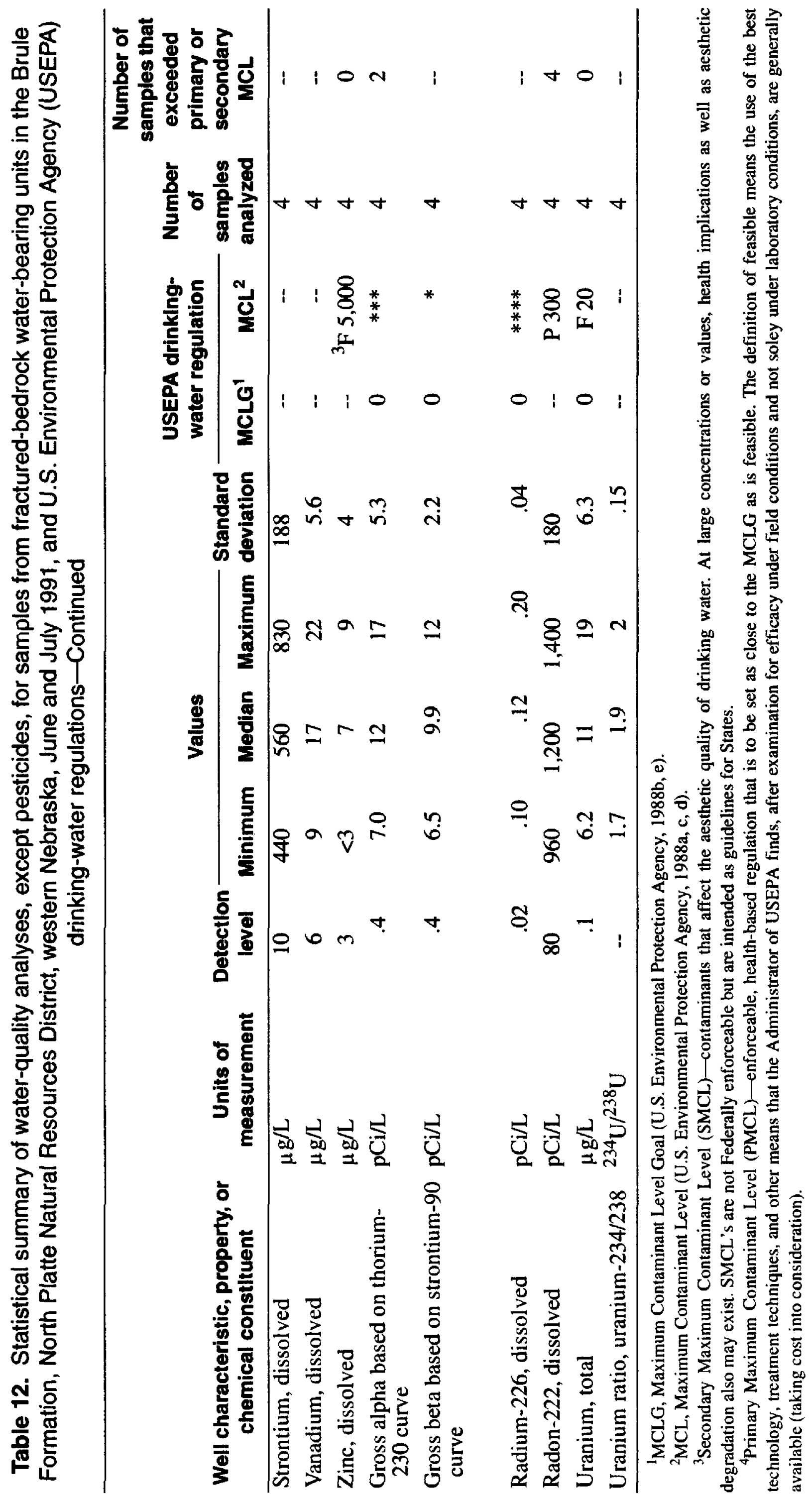




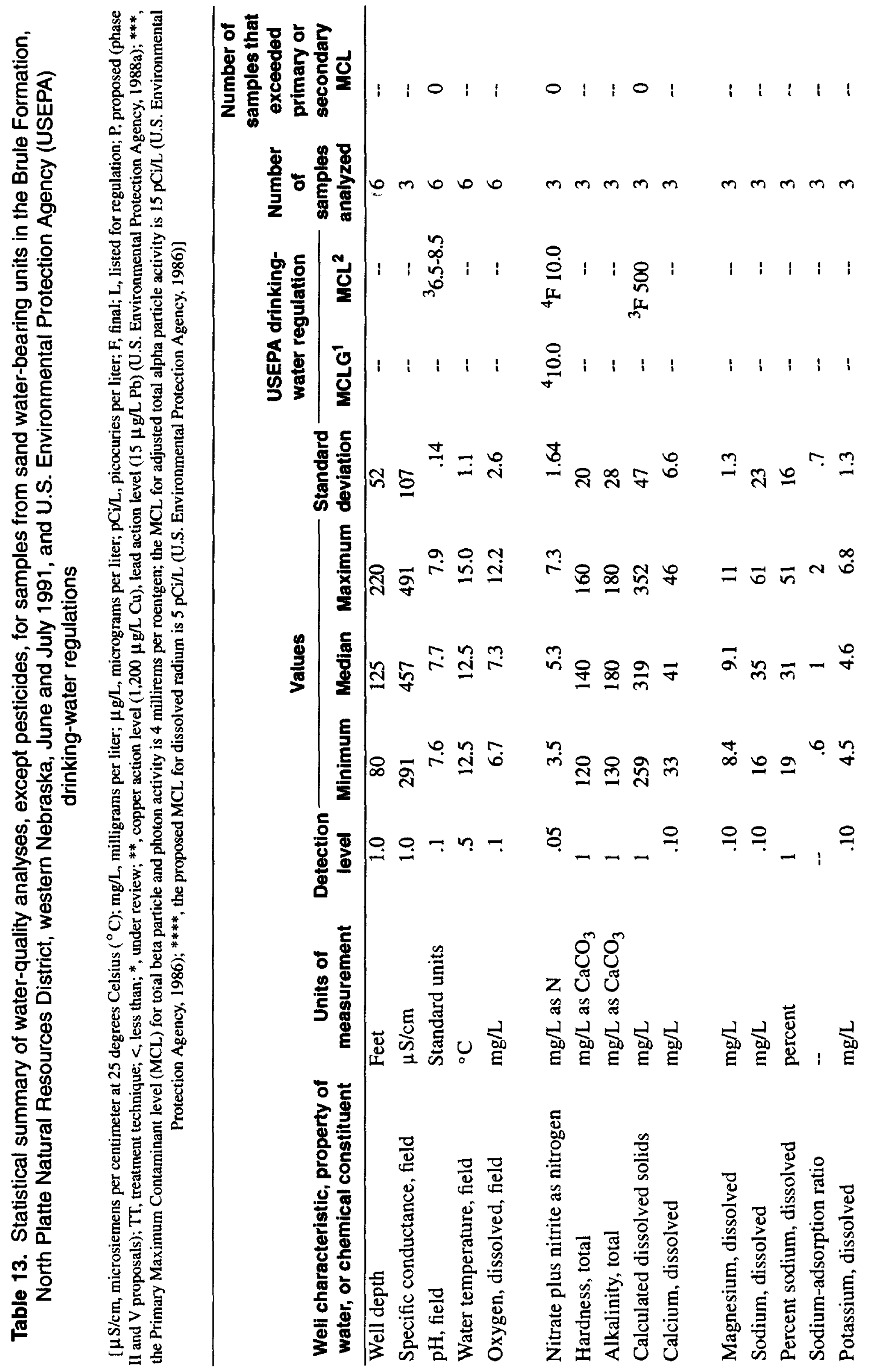




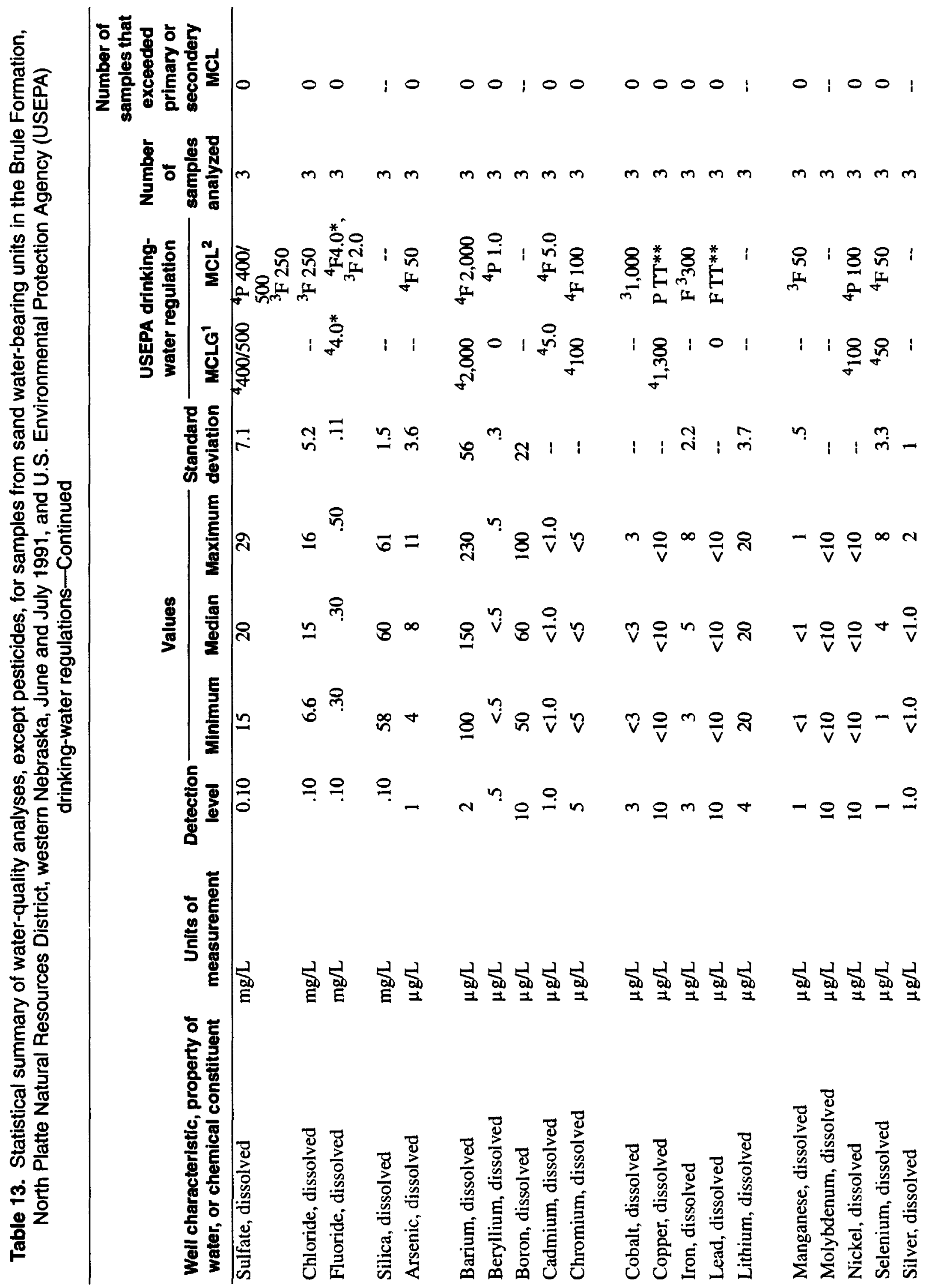




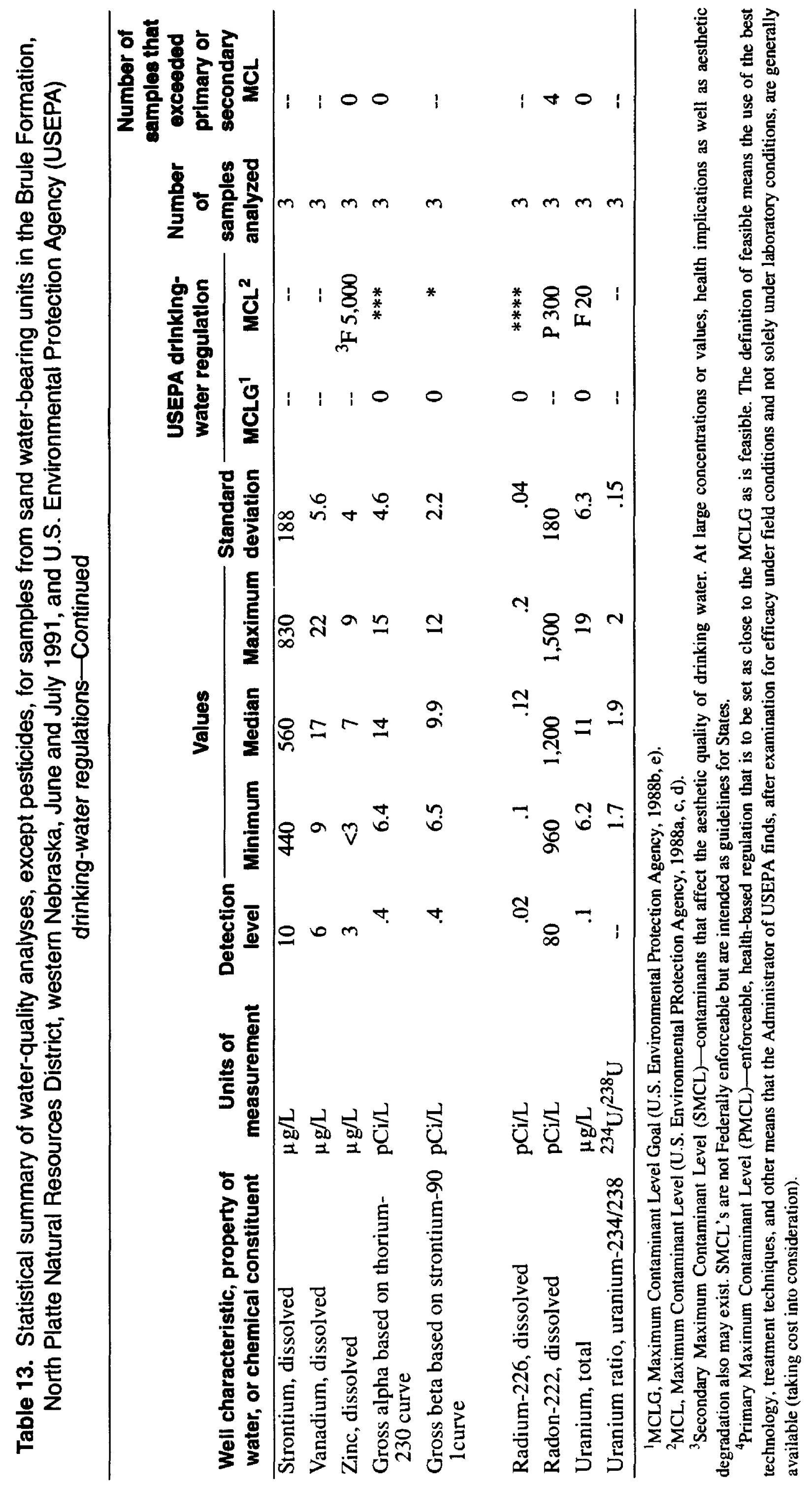




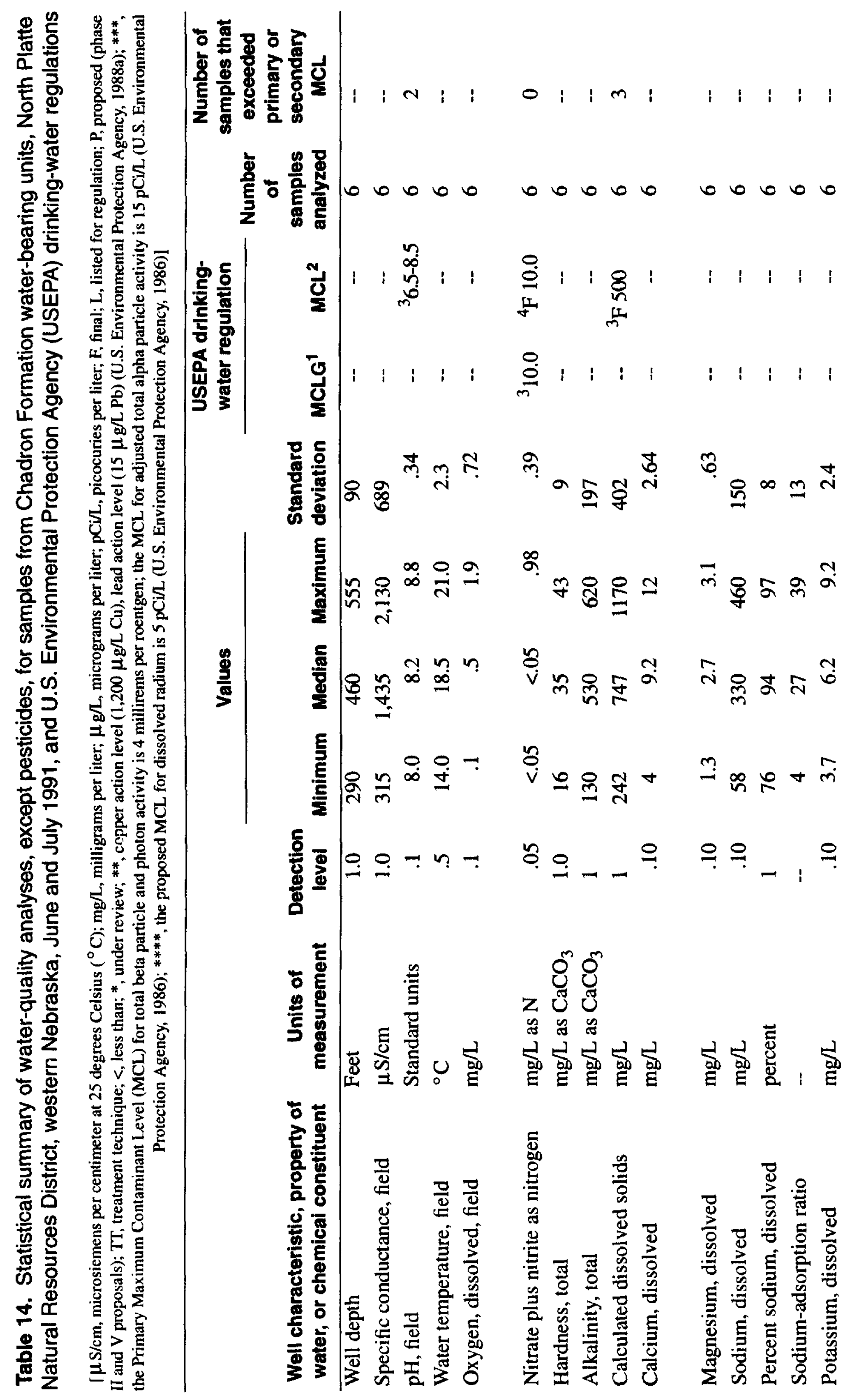




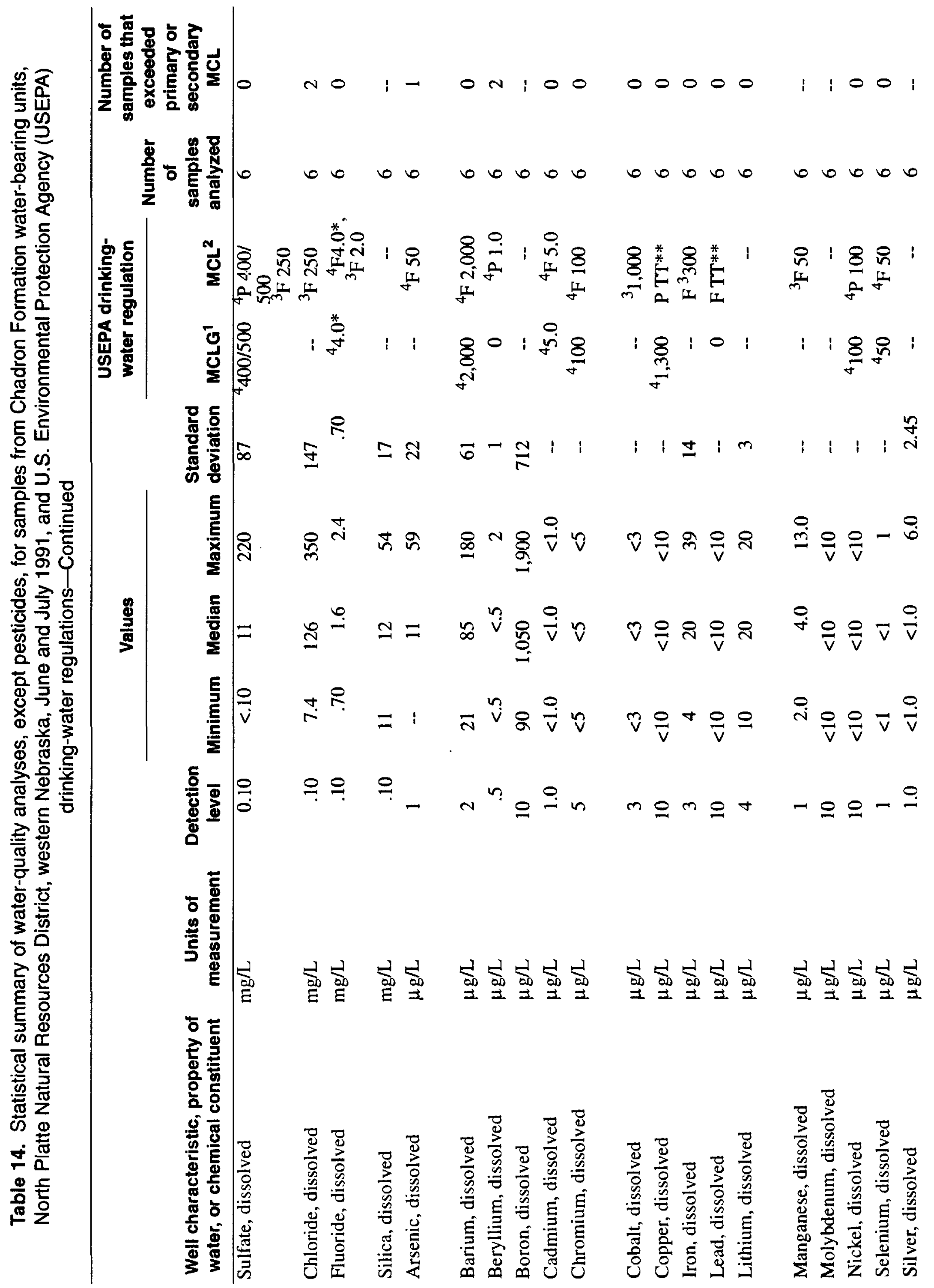




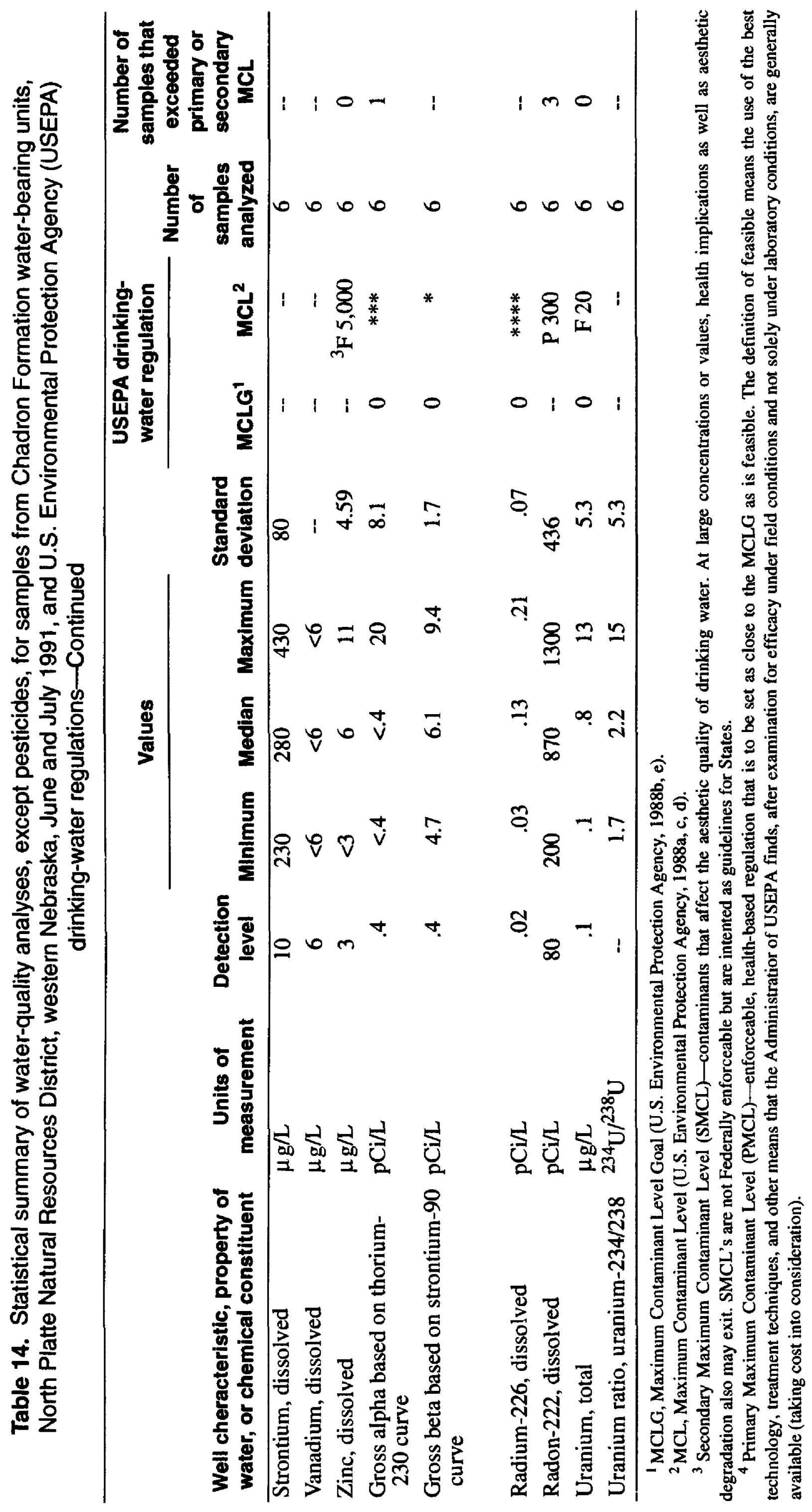




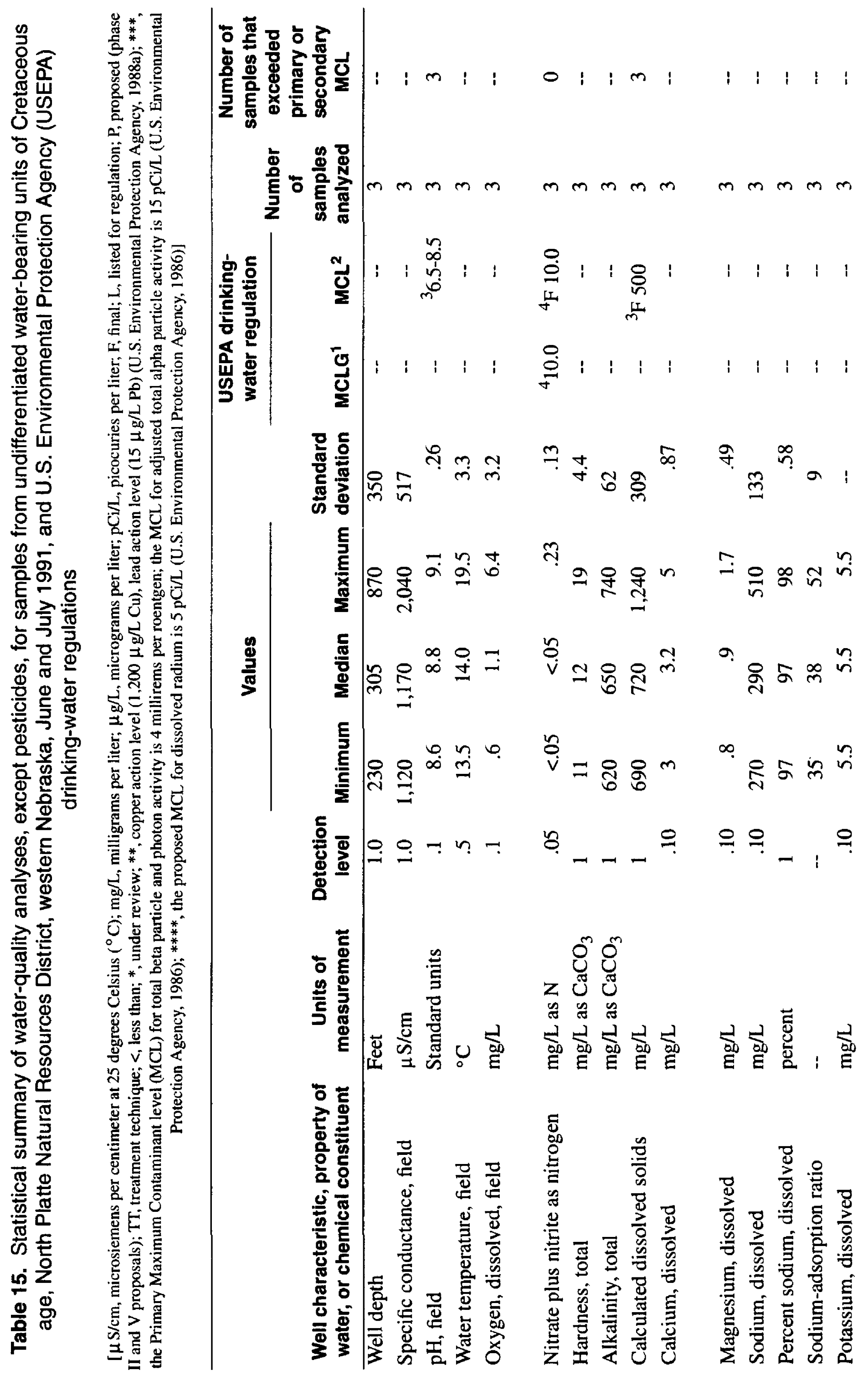




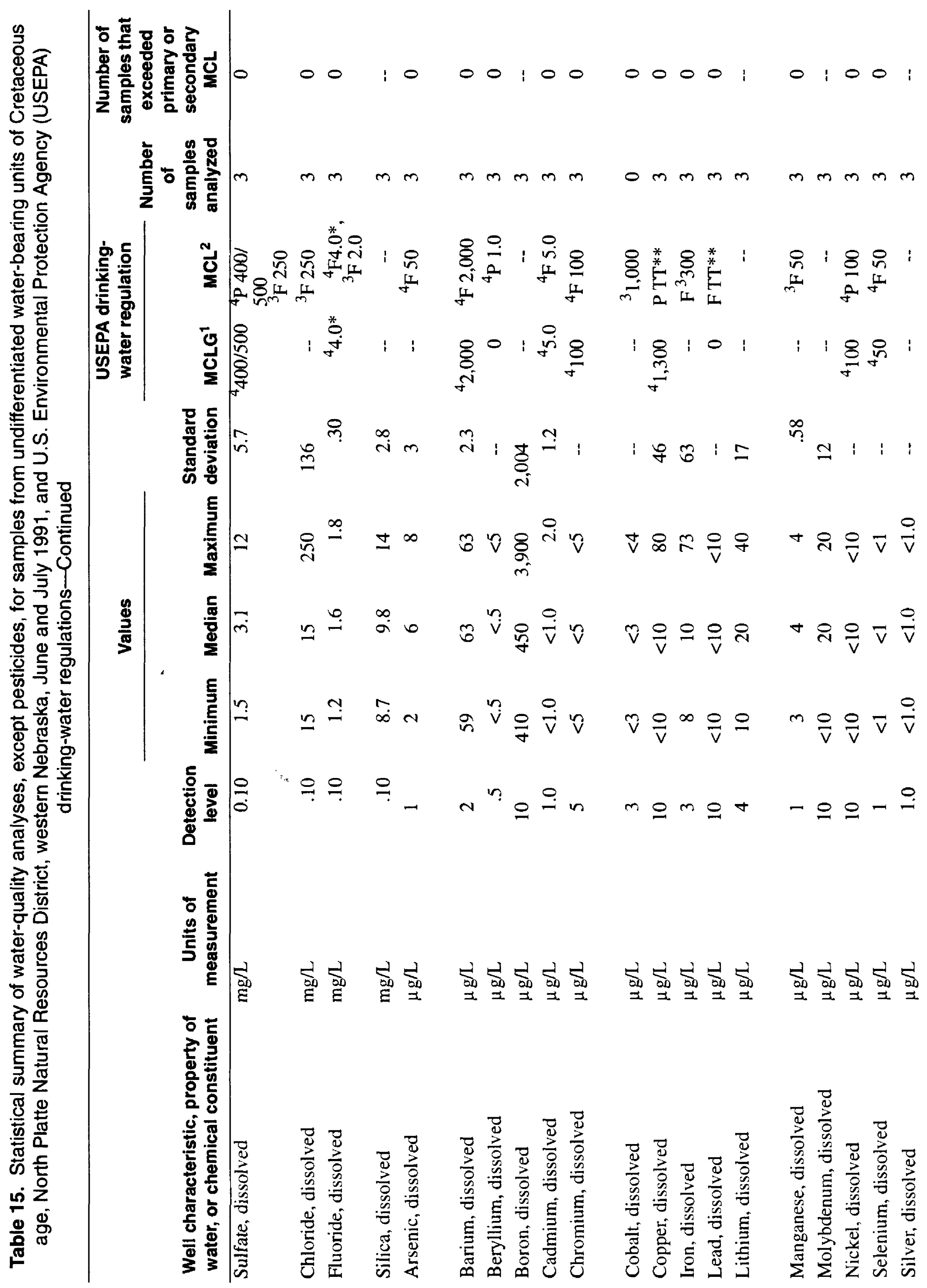




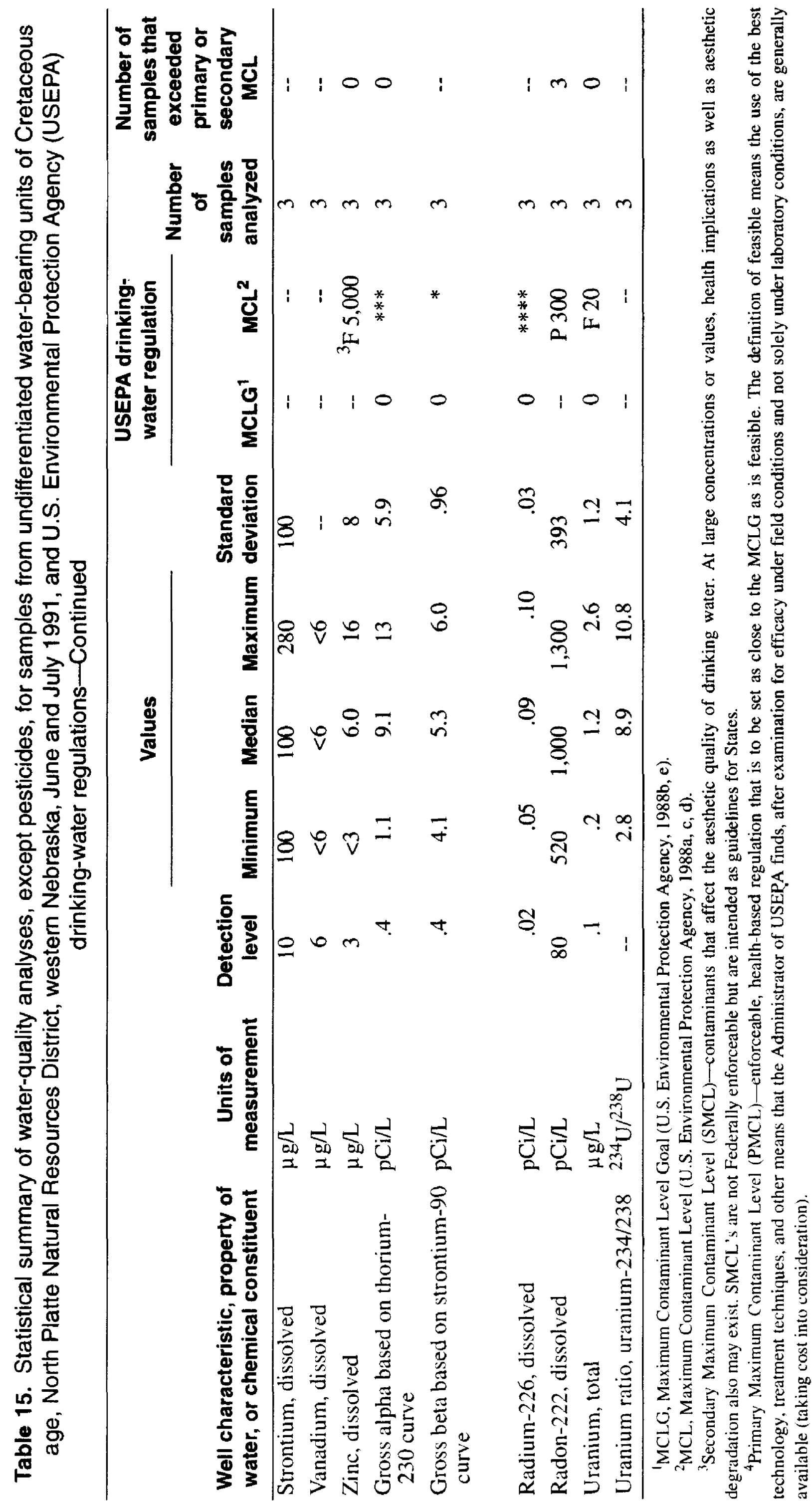


Table 16. Results of Kruskal-Wallis and Wilcoxon Rank Sum tests on differences in water chemistry among water-bearing units and two groups of water-bearing units, respectively

, indicates significant differences at an alpha level of $0.05 ;<$, less than]

\begin{tabular}{|c|c|c|c|c|}
\hline \multirow[b]{3}{*}{ Varlabies* } & \multicolumn{4}{|c|}{ Probabilites p-values of differences } \\
\hline & \multirow[b]{2}{*}{$\begin{array}{l}\text { Kruskal- } \\
\text { Wailis test }\end{array}$} & \multicolumn{3}{|c|}{ Wiicoxon Rank Sum test } \\
\hline & & $\begin{array}{l}\text { Quaternary-age } \\
\text { water-bearing } \\
\text { units compared } \\
\text { to other water- } \\
\text { bearing unita }\end{array}$ & $\begin{array}{l}\text { Fractured- } \\
\text { bedrock and sand } \\
\text { water-bearing } \\
\text { units in the Bruie } \\
\text { Formation } \\
\text { compared to } \\
\text { other water- } \\
\text { bearing units }\end{array}$ & $\begin{array}{l}\text { Chadron } \\
\text { Formation and } \\
\text { undifferentiated } \\
\text { Cretaceous } \\
\text { compared to } \\
\text { other water- } \\
\text { bearing units }\end{array}$ \\
\hline Well depth & $\leq 0.00001$ & $\leq 0.00001$ & 0.54384 & $\leq 0.00001$ \\
\hline Specific conductance, field & .29866 & .86514 & .31064 & .10931 \\
\hline $\mathrm{pH}$, field & .00002 & .00001 & .13746 & .00001 \\
\hline Water temperature, field & .00042 & .00034 & .96219 & .00035 \\
\hline Oxygen, dissolved & .0021 & .26902 & .00132 & .00005 \\
\hline Nitrate plus nitrite as nitrogen & $\leq .00001$ & .00206 & .05408 & $\leq .00001$ \\
\hline Hardness & .00002 & $\leq .00001$ & .54209 & $\leq .00001$ \\
\hline Alkalinity & .00083 & .42435 & .03558 & .00037 \\
\hline Calculated dissolved solids & .00808 & .02130 & .16277 & .25044 \\
\hline Calcium & .00001 & $\leq .00001$ & .47032 & $\leq .00001$ \\
\hline Magnesium & .00008 & .00001 & .74831 & $\leq .00001$ \\
\hline Sodium & .00014 & .88789 & .11221 & .00002 \\
\hline Percent sodium & .00016 & .30673 & .64174 & $\leq .00001$ \\
\hline Sodium-adsorption ratio & .00010 & .71570 & .26141 & .00001 \\
\hline Potassium & .00203 & .00001 & .02795 & .02072 \\
\hline Sulfate & .00549 & .00009 & .76050 & .00571 \\
\hline Chloride & .00553 & .44507 & .63029 & .00597 \\
\hline Fluoride & .00085 & .04454 & .04159 & .00001 \\
\hline Silica & .00048 & .99049 & .00350 & .00003 \\
\hline Arsenic & .89515 & .81424 & .98712 & .98835 \\
\hline Barium & .20272 & .69824 & .05420 & .02153 \\
\hline Beryllium & .74168 & .39761 & .36895 & .54119 \\
\hline Boron & .00016 & .52581 & .05420 & .00005 \\
\hline Cadmium & .95707 & .81424 & .72411 & .78224 \\
\hline Cobalt & .96234 & .62171 & .64174 & .69447 \\
\hline
\end{tabular}


Table 16. Results of Kruskal-Wallis and Wilcoxon Rank Sum tests on differences in water chemistry among water-bearing units and two groups of water-bearing units, respectively-Continued

\begin{tabular}{|c|c|c|c|c|}
\hline \multirow[b]{3}{*}{ Variables ${ }^{*}$} & \multicolumn{4}{|c|}{ Probabilitea p-values of differences } \\
\hline & \multirow[b]{2}{*}{$\begin{array}{l}\text { Kruskal- } \\
\text { Wallis test }\end{array}$} & \multicolumn{3}{|c|}{ Wilcoxon Rank Sum test } \\
\hline & & $\begin{array}{l}\text { Quaternary-age } \\
\text { water-bearing } \\
\text { units compared } \\
\text { to other water- } \\
\text { bearing unita }\end{array}$ & $\begin{array}{l}\text { Fractured- } \\
\text { bedrock and sand } \\
\text { water-bearing } \\
\text { units in the Brule } \\
\text { Formation } \\
\text { compared to } \\
\text { other water- } \\
\text { bearing units }\end{array}$ & $\begin{array}{l}\text { Chadron } \\
\text { Formation and } \\
\text { undifferentiated } \\
\text { Cretaceous } \\
\text { compared to } \\
\text { other water- } \\
\text { bearing units }\end{array}$ \\
\hline Copper & 0.98876 & 0.80513 & 0.91056 & 0.61063 \\
\hline Iron & .01580 & .07041 & .89786 & .00026 \\
\hline Lithium & .01116 & .00031 & .04665 & .64155 \\
\hline Manganese & .04938 & .94379 & .09521 & .00185 \\
\hline Molybdenum & .58216 & .45921 & .57444 & .05301 \\
\hline Selenium & .00056 & .01008 & .02369 & .00003 \\
\hline Silver & .98761 & .62171 & .64174 & 69447 \\
\hline Strontium & .00062 & .00011 & .41323 & .00010 \\
\hline Vanadium & .00139 & .24959 & .52104 & .00002 \\
\hline Zinc & .28491 & .19624 & .43179 & .55086 \\
\hline Gross alpha based on thorium- 230 curve & .02062 & .00415 & .36046 & .00743 \\
\hline Gross beta based on strontium- 90 curve & .00042 & .00001 & .56355 & .00236 \\
\hline Radon-222 & .00054 & .01939 & .00031 & .04625 \\
\hline Radium-226 & .10133 & .03651 & .84734 & .11956 \\
\hline Uranium & .00193 & .00021 & .56355 & .00021 \\
\hline Uranium ratio-234/238 & .00611 & .00023 & .76050 & .00416 \\
\hline
\end{tabular}

*, all concentrations of chromium, lead, and nickel were less than the detection level.

The Kruskal-Wallis test was used to determine that at least 1 percent of all tested populations was significantly different from each other without identifying which one is different, the alpha value reflects the chance of rejecting the null hypothesis when it is true. The null hypothesis means that the distributions of concentrations among populations are the same. 
Table 17. Statistically significant results (alpha $=0.05$ ) of the Tukey's test to test for differences in median concentrations of water-quality variables among water-bearing units, North Platte Natural Resources District, western Nebraska

[Group medians with boxes shaded along the same row are not significantly different from each other and illustrate the pattern of concentration levels of Cthe data; Q, Quaternary age; O, Ogallala Group; A, Arikaree Group; BF, fractured bedrock in the Brule Formation; BS, sand in the Brule Formation; CH, Chadron Formation; CR, undifferentiated units of Cretaceous age]

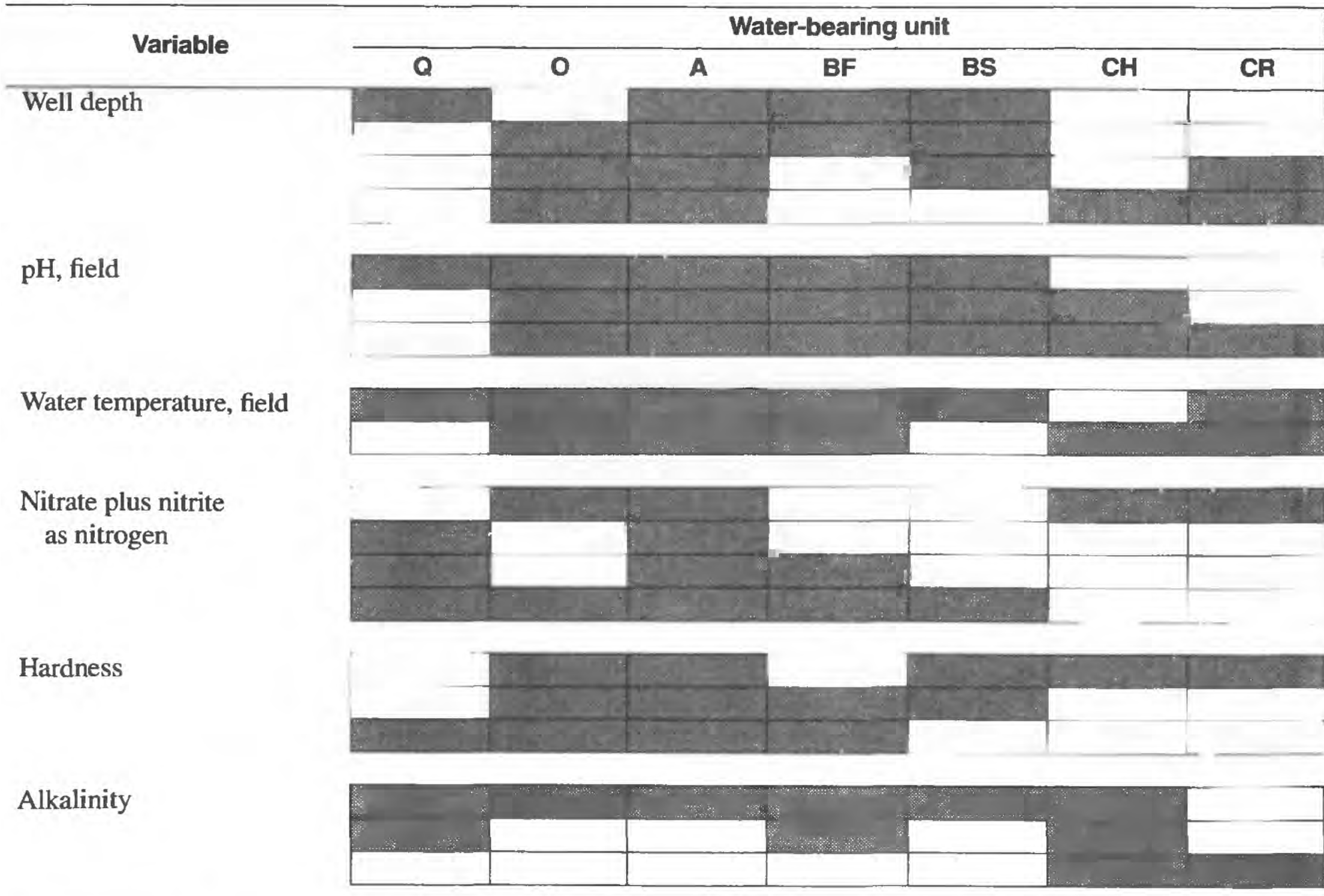

Dissolved solids

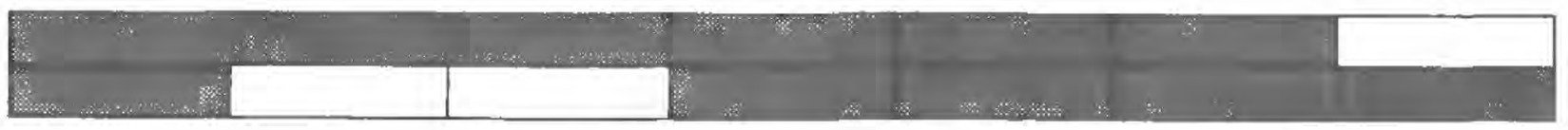

Calcium

Magnesium
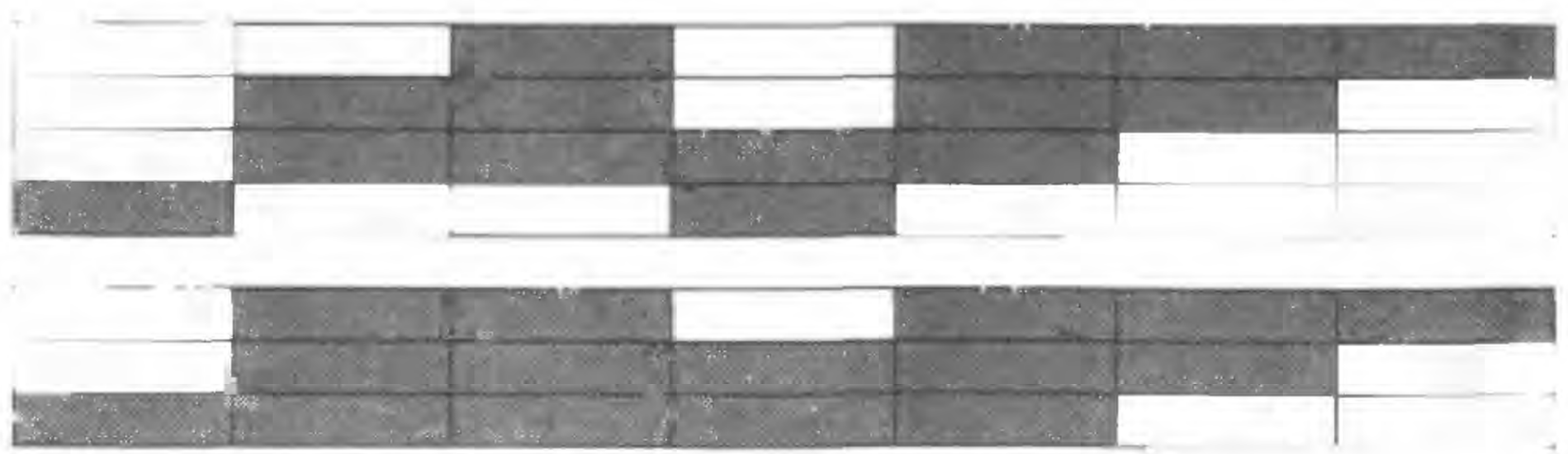

Sodium

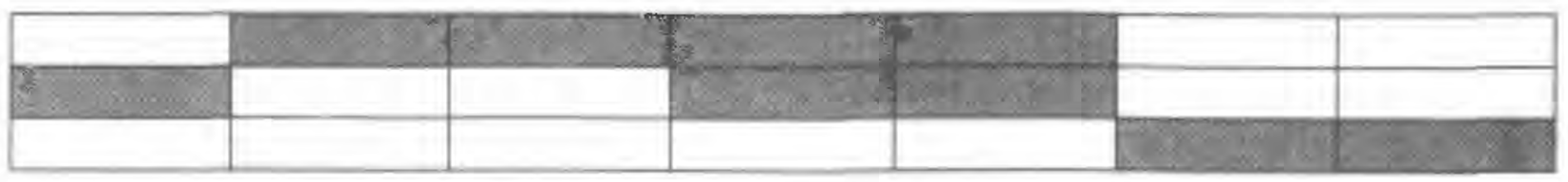

Percent sodium

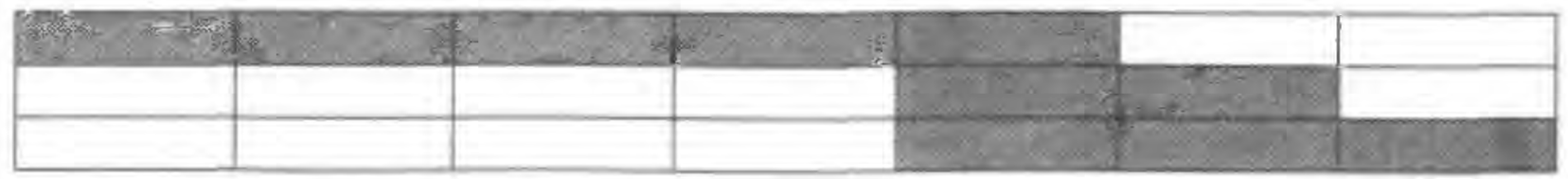


Table 17. Statistically significant results (alpha $=0.05$ ) of the Tukey's test to test for differences in median concentrations of water-quality variables among water-beaning units, North Platte Natural Resources District, western Nebraska-Continued

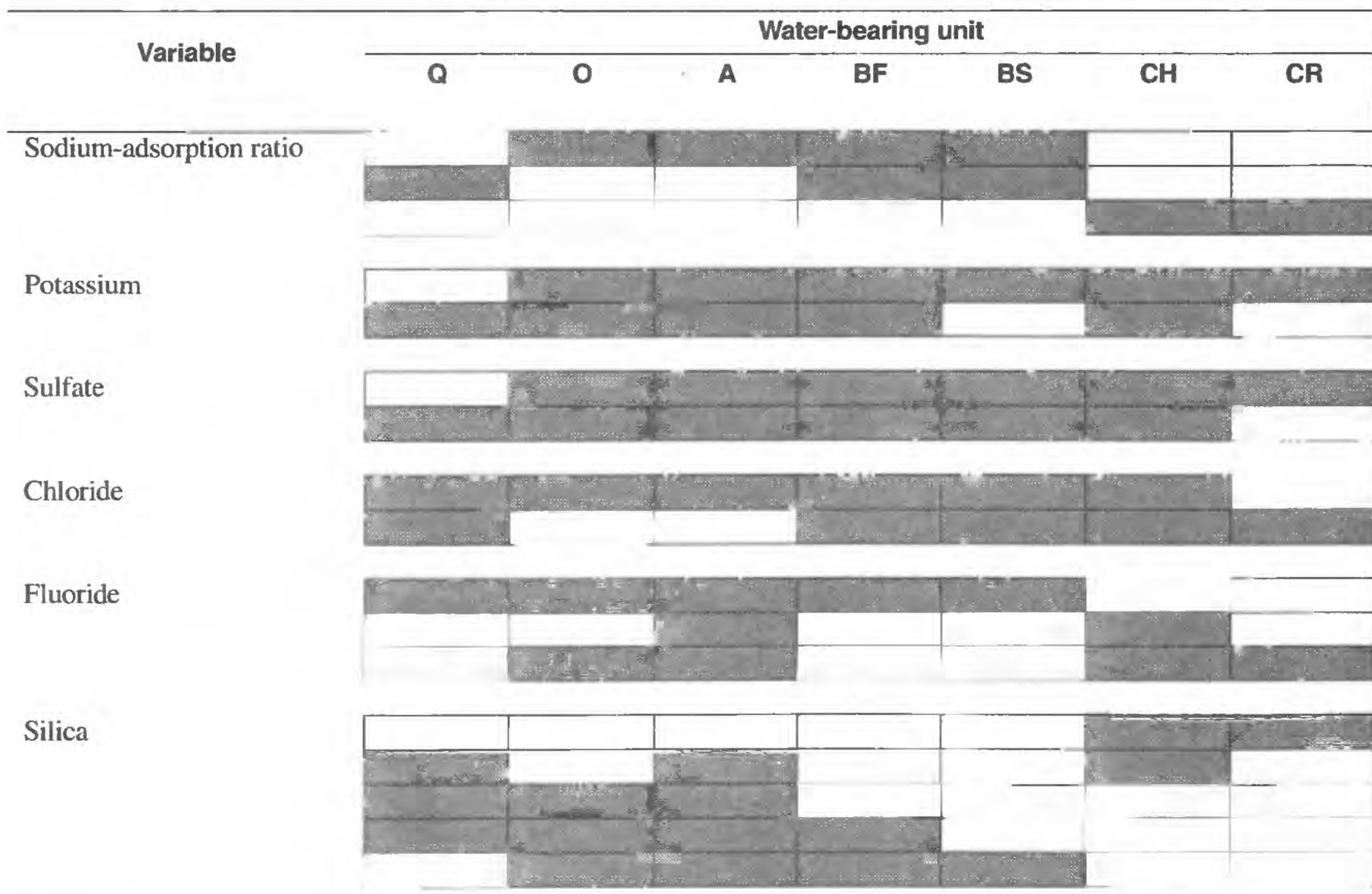

Arsenic

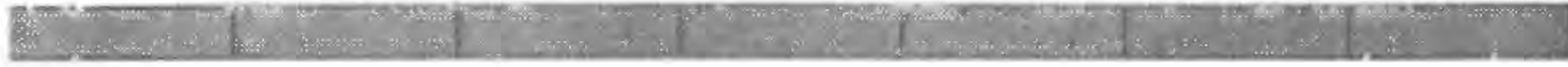

Barium

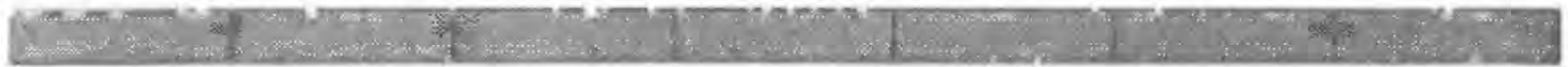

Beryllium

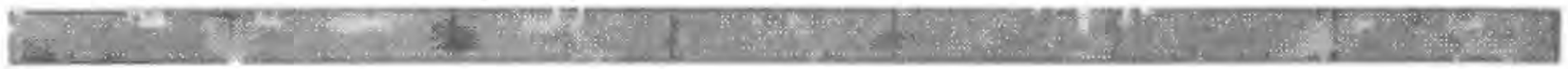

Boron

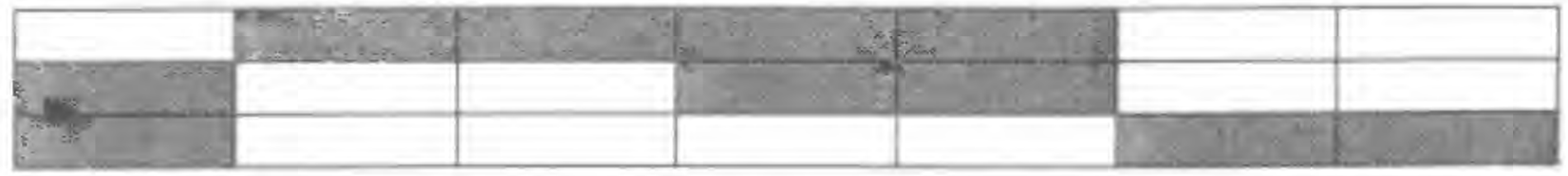

Iron

Lithium

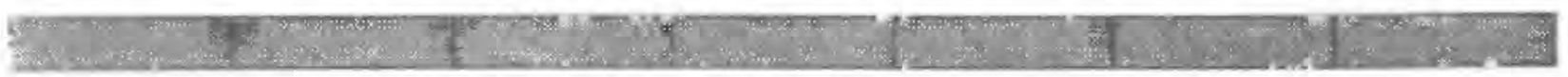

Selenium

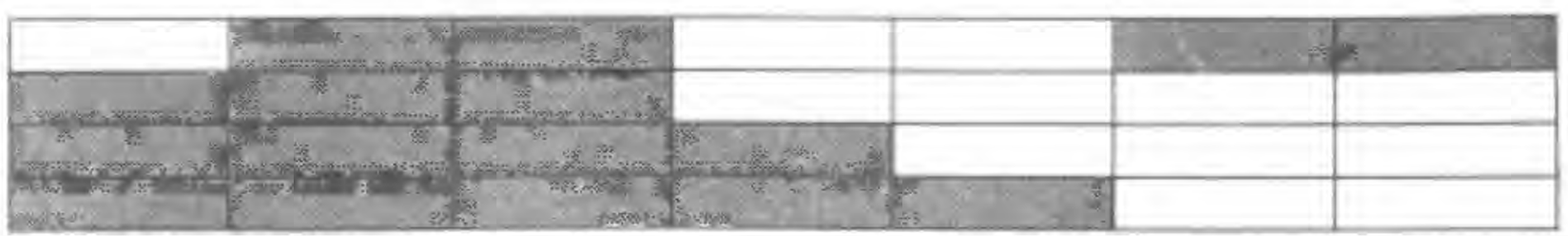

Silver

Strontium

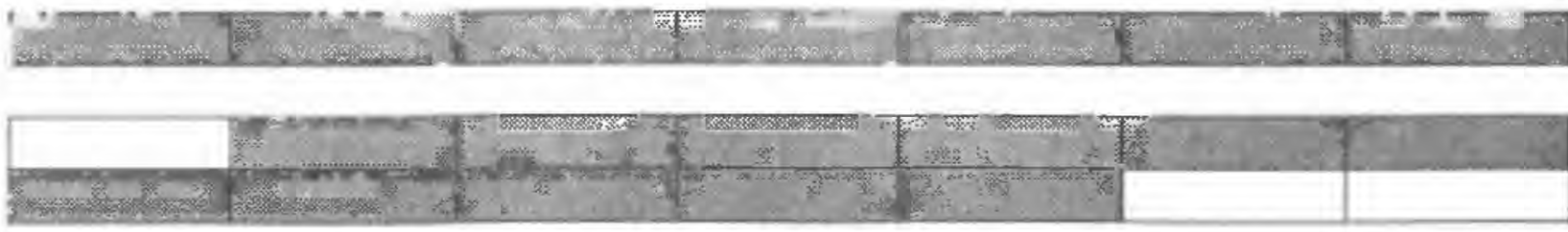


Table 17. Statistically significant results $(a l p h a=0.05)$ of the Tukey's test to test for differences in median concentrations of water-quality variables among water-bearing units, North Platte Natural Resources District, western Nebraska-Continued

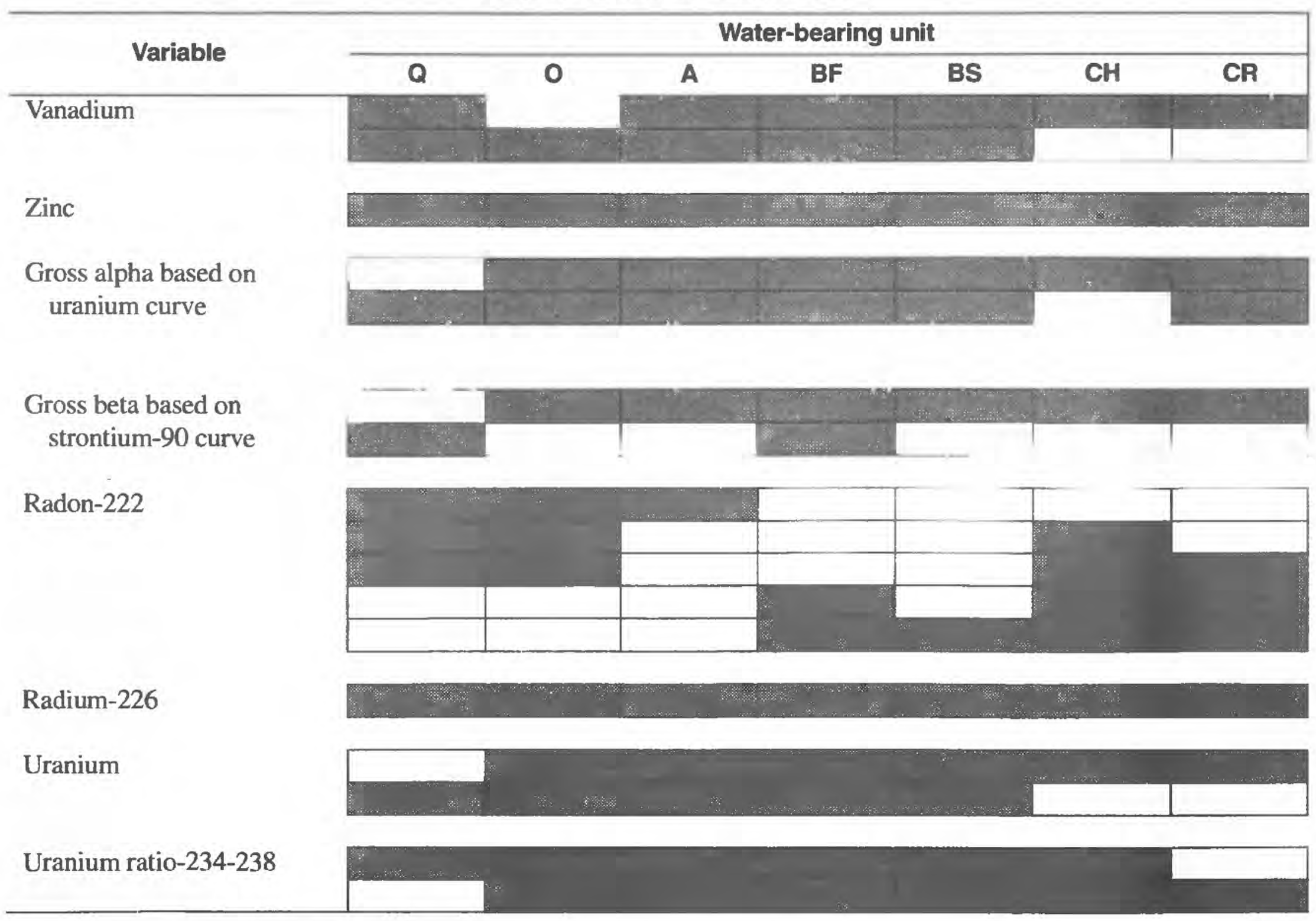

